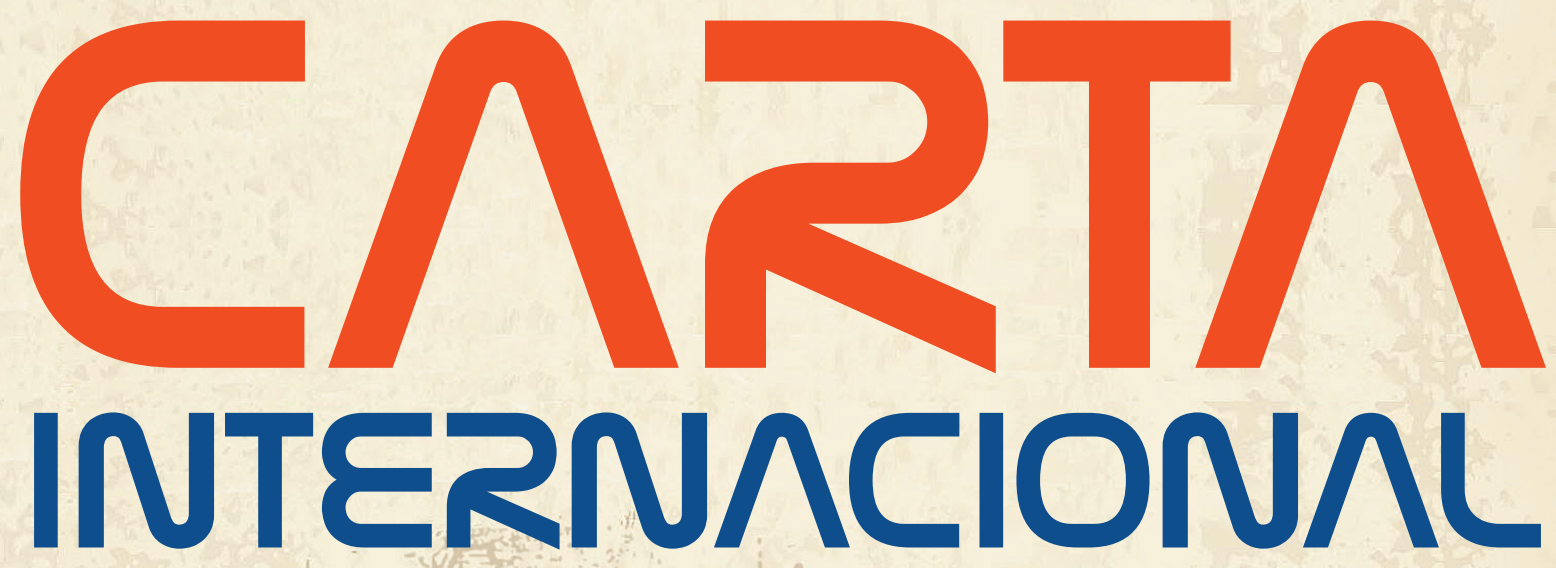

PUBLICAÇÃO DA ASSOCIAÇÃO BRASILEIRA DE RELAÇÕES INTERNACIONAIS

ISSN 1413-0904 - V. 12, No 1, janeiro/abril de 2017 - DOI: $10.12530 /$ ci.v12n1.2017 


\section{Expediente}

Carta Internacional é uma revista eletrônica de publicação quadrimestral dedicada ao debate sobre as questões mais relevantes das relações internacionais sob a perspectiva brasileira. As opiniões expressas nos artigos assinados são de responsabilidade exclusiva de seus autores e não expressam as opiniões da Associação Brasileira de Relações Internacionais (ABRI).

A Revista Carta Internacional foi fundada em 1993 por José Augusto Guilhon Albuquerque, no Núcleo de Pesquisas em Relações Internacionais da Universidade de São Paulo (NUPRI/USP). Em 2011 tornou-se a publicação científica da Associação Brasileira de Relações Internacionais (ABRI).

Carta Internacional é publicada pela Associação Brasileira de Relações Internacionais (ABRI). A revista está disponível para download gratuito, em formato PDF, no endereço:

< http://www.cartainternacional.abri.org.br > .

\section{Editora Chefe:}

Matilde de Souza

\section{Editora Associada:}

Letícia Carvalho

\section{Editores Assistentes}

Rebeca Caeiro e Mateus Silva

\section{Diagramação:}

Samuel Tabosa

\section{Revisão:}

Luís Fernando dos Reis Pereira

\section{Secretaria da Carta Internacional:}

Airá Eventos Técnico-Científicos

\section{Conselho Científico:}

Amado Luiz Cervo, André Singer, Andrew Hurrell, Antônio Carlos Lessa, Arlene Tickner, Anthony Pereira, Carlos Eduardo Lins da Silva, David Mares, Eduardo Viola, Elizabeth Balbachevsky, Félix Peña, Fernando Augusto Albuquerque Mourão, Gary Hufbauer, Gilson Schwartz, Gladys Lechini, Gustavo Vega-Cánovas,
Henrique Altemani de Oliveira, José Augusto Guilhon Albuquerque, Luis Olavo Baptista, Margarita Silvia Olivera, Maria Cristina Cacciamali, Maria Regina Soares de Lima, Paulo Fagundes Vizentini, Paulo Lavigne Esteves, Peter Demant, Rafael Antônio Duarte Villa, Sean Burges e Tullo Vigevani.

Redes Sociais:

Facebook: Carta Internacional

Twitter: @CartaAbri

LinkedIn: Revista Carta Internacional

Academia.edu: Revista Carta Internacional

\section{Associação Brasileira de Relações Internacionais (ABRI)}

\section{Presidente:}

Eugênio Pacelli Lazzarotti Diniz Costa (PUC Minas)

\section{Secretária Executiva:}

Layla Ibrahim Abdallah Dawood (UERJ)

\section{Secretária Executiva Adjunta:}

Graciela De Conti Pagliari (UFSC)

\section{Tesoureira:}

Cristina Soreanu Pecequilo (UNIFESP)

\section{Diretores:}

Deisy de Freitas Lima Ventura (USP)

Hector Luis Sant Pierre (UNESP)

Henrique Altemani de Oliveira (UEPB)

Marcos Ferreira da Costa Lima (UFPE)

Conselho Fiscal:

Alexandre Ratsuo Uehara

(Faculdades Integradas Rio Branco)

\section{Correspondência:}

Avenida Dom José Gaspar, 500 - Prédio 04 - Sala 01 Coração Eucarístico Belo Horizonte, MG - CEP: 30535-901 Tel.: + 55 (31) 3241-5123 email: cartainternacional@abri.org.br

(C) 2017 Associação Brasileira de Relações Internacionais (ABRI). Todos os direitos reservados. 


\section{Sumário}

A política externa da União Europeia e a construção de capacidades estatais securitárias | European Union foreign policy and the construction of state security capabilities | 5

Marília Bortoluzzi Severo

Ana Luiza Brandes Becher

Kim Barros Bacedo

Cooperação Internacional para o Desenvolvimento e Cooperação Sul-Sul: uma análise comparativa de seus princípios e desafios de gestão | International Cooperation for Development and South-South Cooperation: a comparative analysis of principles and challenges for management | 28 Rosana Correa Tomazini

T-TIP against the wall: feasibility, resistance, and consequences for third countries | T-TIP contra a parede: viabilidade, resistência e consequências para países terceiros $\mid 49$

Ana Paula Tostes

International Cooperation, Overseas Development, Foreign Assistance: brief historical and bibliographic review on Foreign Aid | Cooperação Internacional, Desenvolvimento Ultramar, Assistência Estrangeira: breve revisão histórica e bibliográfica sobre a ajuda externa oficial | 73 Ana Maura Tomesani

O fenômeno dos "Estados emergentes" na política internacional contemporânea: contribuições da Economia Política Internacional para um objeto multi-aspectual | The phenomenon of the "Emergent Countries" in the contemporary international politics: contributions from International Political Economy for a multi-aspectual object | 101 
A path dependence na inserção internacional da Guiana | Path dependence and Guyana's international insertion | 123

Marcelino Teixeira Lisboa

Ronaldo Silva

Estudos da paz: origens, desenvolvimentos e desafios críticos atuais | Peace studies: origins, developments and current critical challenges | 148 Gilberto Carvalho de Oliveira

A Escola Galesa de Estudos Críticos em Segurança Internacional:

25 anos depois | The Welsh School of Critical Security Studies: 25 years after | 173 Aureo de Toledo Gomes

A parceria entre Minas Gerais e o Banco Mundial: uma análise do uso de condicionantes como instrumento de influência | The partnership between Minas Gerais and the World Bank: an analysis of the use of conditionality as an influence tool | 198

Diogo de Paula Oliveira

Pascoal Teófilo Carvalho Gonçalves

Comunidades de Relações Internacionais na América Latina: uma análise das tendências a partir do TRIP 2014 | International Relations Communities in Latin America: an analysis of trends from TRIP 2014 | 224 Rafael Duarte Villa

Arlene B. Tickner

Marília Carolina B. Souza

Yamile Carolina Cepeda Másmela 


\title{
A política externa da União Europeia e a construção de capacidades estatais securitárias ${ }^{1}$
}

\author{
European Union foreign policy and the \\ construction of state security capabilities
}

DOI: $10.21530 /$ ci.v12n1.2017.637

Marília Bortoluzzi Severo $^{2}$
Ana Luiza Brandes Becher
Kim Barros Bacedo

\section{Resumo}

No início da década de 1990, diversos desafios - como a dissolução da Iugoslávia - foram responsáveis pelo aprofundamento da integração europeia e pelo estabelecimento da Política Externa e de Segurança Comum (PESC). Essa, mais tarde, teria na Política Comum de Segurança e Defesa (PCSD) o seu braço mais visível de intervenção securitária regional. A partir daí, vários eventos tiveram repercussão na imagem da União como ator capaz de promover e manter a paz e a segurança, provocando a discussão sobre o seu papel na estabilidade do sistema internacional. Com a inserção na agenda da UE da necessidade de relações com a vizinhança que garantam a paz na Europa, a sua política externa passou a se voltar à interferência na elaboração de políticas securitárias domésticas nos Estados vizinhos mais frágeis. Por esse motivo, esta pesquisa oferece uma reflexão sobre a compreensão da atuação da UE em questões securitárias que envolvem países vizinhos não membros do bloco, objetivando, com isso, sugerir observações e questionamentos a respeito da atuação da UE no reforço dos domínios de segurança dos Estados que partilham a vizinhança na região.

Palavras-chave: União Europeia; segurança; capacidade policial.

1 Este estudo é fruto do projeto de pesquisa "O papel da Política Externa da União Europeia na construção de capacidades estatais de segurança: reforma do setor policial em Bósnia-Herzegovina, Macedônia e Ucrânia”, sob coordenação da Dra. Marília Bortoluzzi Severo, desenvolvido no contexto do Grupo de Estudos em Segurança e Defesa (GESED) da Universidade Federal de Santa Catarina (UFSC), bem como apoiado pelo Programa Nacional de Pós-Doutorado (PNPD) da Coordenação de Aperfeiçoamento de Pessoal de Nível Superior (CAPES).

2 Doutora em Ciência Política pela Universidade Federal do Rio Grande do Sul (UFRGS), com pós-doutorado no Programa de Pós-Graduação em Relações Internacionais (PPGRI) da Universidade Federal de Santa Catarina (UFSC). E-mail para contato: marilia_bortoluzzi@yahoo.com.br

3 Graduanda em Relações Internacionais pela Universidade Federal de Santa Catarina (UFSC). E-mail para contato: ana.bbecher@gmail.com

4 Graduando em Relações Internacionais pela Universidade Federal de Santa Catarina (UFSC). E-mail para contato: kimbacedo@gmail.com

Artigo submetido em 13/02/2017 e aprovado em 13/04/2017. 


\begin{abstract}
In the early 1990s, various challenges - such as the dissolution of Yugoslavia - were responsible for deepening European integration and for establishing the Common Foreign and Security Policy (CFSP). The CFSP would later have its most visible arm of regional security intervention in the Common Security and Defense Policy (CSDP). Since then, several events have had repercussion on the Union's image as an actor capable of promoting and maintaining peace and security, provoking the discussion about its role in the stability of the international system. By inserting into EU's agenda the need for neighborly relations to ensure peace in Europe, its foreign policy has turned to the interference in the development of the domestic politics and policies in the most fragile neighboring states. For this reason, this research offers a reflection on the comprehension of the EU's action on security issues involving neighboring countries, non-Member States, with the aim of suggesting observations and sharing questions about the EU's role in strengthening the security policy of its neighborhood.
\end{abstract}

Keywords: European Union; security; police.

\title{
Introdução
}

Em uma perspectiva regional, a União Europeia (UE) é a provedora de um modelo securitário que ultrapassa suas fronteiras e alcança o território europeu continental a leste e sudeste. Tal modelo tem sido expandido através da promoção de diretrizes e práticas políticas do bloco europeu aos sistemas de segurança domésticos dos Estados vizinhos, no tocante à expertise de profissionais, à estrutura e às políticas desenvolvidas no domínio securitário.

Tal estratégia de relacionamento com os países vizinhos faz parte da Política Externa e de Segurança Comum (PESC), que consubstancia o quadro instrumental da política externa da UE5 5 . Ao abrigo da PESC, encontram-se ferramentas de política externa e de outras políticas setoriais e regionais, principalmente dos campos da segurança e da defesa, que permitem à UE atuar com legitimidade no sistema internacional, tanto em questões de alcance regional quanto global. Um exemplo dessas ferramentas é a Política Comum de Segurança e Defesa (PCSD), que trata de missões e operações de manutenção da paz e de prevenção de conflitos, como parte da abordagem global da UE para gestão de crises, apoiada em meios civis e militares (EEAS, 2016). Outros exemplos que precisam ser mencionados são

5 Como aponta Ferreira-Pereira (2008), é preciso lembrar que a PESC, de fato, é fruto de um longo processo de construção de uma comunidade europeia de segurança, sendo o ponto de partida disso a discussão sobre a Cooperação Política Europeia, no início da década de 1950. 
as políticas regionais de relações exteriores abarcadas pela Política Europeia de Vizinhança $(\mathrm{PEV})^{6}$ e pela Política de Alargamento. Enquanto a primeira refere-se ao relacionamento da UE com países de uma parte específica dos continentes europeu, africano e asiático (Argélia, Armênia, Azerbaijão, Bielorrússia, Egito, Geórgia, Israel, Jordânia, Líbano, Líbia, Marrocos, Moldávia, Palestina, Síria, Tunísia e Ucrânia), a segunda trata das relações entre UE e os Estados europeus candidatos à adesão ao bloco (a saber: Albânia, Macedônia, Montenegro, Sérvia, Turquia, Bósnia-Herzegovina e Kosovo7 ${ }^{7}$.

Com o recente agravamento de ataques terroristas (que passaram a ser discutidos pela mídia internacional a partir dos atentados em Paris em 2015 e 2016) em diversos Estados membros e o debate contemporâneo provocado pelo intenso fluxo de refugiados para esse continente, mais do que nunca, temas securitários cruciais estão sendo inseridos na agenda das relações externas da UE com os países vizinhos. A PESC e a PCSD constituem os instrumentos que abrangem tais temas e que apresentam um quadro estrutural que permite tal inserção. Por esse motivo, este estudo propõe a reflexão sobre a relação entre a ação externa da UE e a construção de capacidades securitárias na vizinhança europeia. Em específico, o objetivo é verificar o impacto de três missões da PESC no desenvolvimento das atividades policiais em relação aos Estados da Bósnia-Herzegovina (BiH), Macedônia ${ }^{8}$ e Ucrânia. As missões em pauta são:

1. Missão de Polícia da UE na Bósnia-Herzegovina (EUPM) ${ }^{9}$ : missão de gestão civil de crise para estabelecer capacidades policiais na $\mathrm{BiH}$, no período 2003-2012;

2. Missão de Polícia da UE Proxima (EUPOL Proxima) e Equipe Consultiva de Polícia da UE (EUPAT) ${ }^{10}$ : missões para o desenvolvimento de forças policiais e para o apoio à implementação da reforma policial na Macedônia, respectivamente, nos períodos 2004-2005 e 2005-2006;

6 Em inglês: European Neighbourhood Policy (ENP).

7 Embora não possua reconhecimento como Estado independente por toda a comunidade internacional - e mesmo dentro da própria UE, Kosovo consta como Candidato Potencial à adesão, sob a égide da Resolução 1244 do Conselho de Segurança da Organização das Nações Unidas (ONU).

8 Apesar de a UE referir-se à República da Macedônia como “Antiga República Iugoslava da Macedônia”, em função da discussão a respeito do nome oficial desse Estado com a Grécia, opta-se por referir-se a tal país como, apenas, Macedônia.

9 Em inglês: EU Police Mission (EUPM) in Bosnia and Herzegovina.

10 Em inglês: EU Police Mission (EUPOL) Proxima in the former Yugoslav Republic of Macedonia (fYROM) e EU Police Advisory Team (EUPAT) in the former Yugoslav Republic of Macedonia (fYROM). 
3. Missão de Aconselhamento da UE sobre a Reforma do Setor de Segurança Civil (EUAM) ${ }^{11}$ : com início em 2014 e ainda em andamento, trata-se de missão para assessoramento à Ucrânia em relação à reforma do setor de segurança civil.

A importância e a conveniência da análise de missões de segurança desenvolvidas pela UE em países como a BiH e a Macedônia parecem ser evidentes, já que o próprio desenvolvimento das ferramentas de ação securitária externa do bloco europeu se deu em decorrência dos conflitos da região balcânica ocidental, ao tempo do início da dissolução da Iugoslávia. Para além disso, a Missão de Polícia da UE na Bósnia-Herzegovina foi a primeira missão a ser lançada dentro do quadro da PESD/PCSD, bem como a primeira com foco no setor policial, o que significa dizer que serviu de caso de teste para a PESC.

Por outro lado, examinar uma missão de cunho policial na Ucrânia mostrase relevante e pertinente em razão da dinâmica securitária regional que envolve União Europeia e Rússia como os maiores provedores de modelos securitários no continente europeu. Embora a secessão da península da Criméia e o conflito da Ucrânia com a Rússia não tenham sido eventos imprevisíveis, não houve consenso dentro da UE sobre "se" e "como" agir em relação ao confronto iminente entre forças russas e ucranianas. Certamente, nessa equação, é preciso considerar que a Rússia sustenta o papel de principal parceiro energético dos europeus, o que os compele a buscar a acomodação política com esses. Porém, a UE trabalha com uma política externa de viés normativo, no sentido da promoção de valores e princípios que podem entrar em choque com a questão russo-ucraniana, o que fundamenta um exame mais aprofundado das atividades da UE em solo ucraniano.

Nessa linha, o estudo aqui apresentado oferece uma reflexão sobre a compreensão da atuação da UE em questões securitárias, tendo como fundamento o significado de três conceitos (que são essenciais para esse debate) na perspectiva desse ator internacional - quais sejam, o próprio termo "segurança", o conjunto de atividades que envolvem o chamado "setor de segurança" e as ações e projetos praticados como "reforma do setor de segurança (SSR) 12". Em seguida, uma breve análise das três missões anteriormente citadas é apresentada. Espera-se, com isso, sugerir observações e questionamentos a respeito da atuação da UE no reforço dos domínios de segurança dos seus Estados vizinhos.

11 Em inglês: EU Advisory Mission (EUAM) for Civilian Security Sector Reform in Ukraine.

12 Em inglês: security sector reform (SSR). 


\section{Como a União Europeia entende o conceito de segurança?}

Tendo em conta uma perspectiva ampla de segurança, a capacidade de atuação securitária da UE está voltada à securitização de questões que se encontram para além de suas fronteiras externas. Isso significa que assuntos e eventos que estão ou ocorrem fora do território da UE têm sido objeto de securitização, processo que designa a elevação de um (ou um conjunto de) ato ou fato à categoria de ameaça, em nome da proteção coletiva, para que o tratamento dado a tal ato ou fato tenha maior ênfase do que outros atos e fatos presentes na agenda de um determinado ator, que pode ser chamado de "ator securitizador".

Para a União, então, o processo de securitizar um assunto ou situação vai mais longe do que a perspectiva tradicional de segurança. No atual sistema internacional, isso envolve definir quais temas ou situações podem gerar tensão suficiente para ameaçar a estabilidade nos mais diversos níveis (global, regional, estatal, nacional e individual/humano).

Nesse ponto, a UE inicia o seu processo de securitização ao delimitar o que está compreendido como ameaça a si própria, aos seus Estados membros e aos seus cidadãos, de modo a envolver todas as dimensões anteriormente citadas. Enquanto ator internacional, ela parte de uma perspectiva multidimensional, com base na ascensão da abordagem teórica da Escola de Copenhague, para justificar a securitização de vários temas não tradicionais ao domínio securitário. Dessa maneira, desde o início da década de 1990, a UE trata a ideia de segurança de forma ampla e transversal.

No entanto, não há uma definição institucional, dentro do acervo comunitário $^{13}$, do que o bloco europeu entende por segurança. Contudo, é possível inferir a percepção da União sobre o tema pelo seguinte trecho:

Precisamos de uma Europa mais forte. Isto é o que os nossos cidadãos merecem, isso é o que o resto do mundo espera. Vivemos em tempos de crise existencial, dentro e fora da União Europeia. A nossa União está sob ameaça. O nosso projeto europeu, que trouxe paz, prosperidade e democracia sem precedentes, está sendo questionado (...)

13 O acervo comunitário (do francês acquis communautaire) é um numeroso e abrangente acervo normativo, que está em desenvolvimento contínuo. Trata-se, portanto, do conjunto das declarações, tratados, leis e políticas da UE, isto é, a base comum de direitos e obrigações que liga os Estados membros à UE e entre si. Além de normas de Direito comunitário propriamente dito, o acervo inclui todos os atos relacionados à PESC e a outros domínios setoriais, bem como a jurisprudência do Tribunal Europeu e acordos e tratados entre a UE e qualquer outro ator internacional (Estados, organismos internacionais, organismos não governamentais etc.). 
A União Europeia irá promover a paz e garantir a segurança de seus cidadãos e território. A segurança interna e a externa estão cada vez mais interligadas: a nossa segurança em casa depende da paz além das nossas fronteiras (...)

Em um mundo mais complexo, devemos permanecer unidos. Somente o peso combinado de uma verdadeira união tem o potencial de oferecer segurança, prosperidade e democracia para os seus cidadãos e fazer uma diferença positiva no mundo. Em um mundo mais conectado, a UE vai se envolver com os outros. A União não pode erguer um muro para afastar ameaças externas. Para promover a segurança e a prosperidade dos nossos cidadãos e para salvaguardar as nossas democracias, nós vamos gerenciar a interdependência, com todas as oportunidades, desafios e medos que ela acarreta, ao envolver o resto do mundo. Em um mundo mais disputado, a UE será guiada por um forte senso de responsabilidade. Vamos nos envolver de forma responsável em toda a Europa e nas regiões vizinhas ao leste e ao sul. Vamos agir globalmente para resolver as causas profundas dos conflitos e da pobreza, e para promover os direitos humanos. (EUROPEAN EXTERNAL ACTION SERVICE, 2016a, p. 7-8, tradução livre'14)

Nesse sentido, a Estratégia de Segurança Europeia (ESE) ${ }^{15}$, aprovada pelo Conselho Europeu, em 2003 (EUROPEAN UNION, 2003), foi o marco inicial da identificação de ameaças no quadro da PESC e da PCSD. Na ESE, o argumento dessa identificação envolve a compreensão de que a democratização e o desenvolvimento socioeconômico são definidos como subprodutos de um ambiente seguro (RYAN, 2009).

De acordo com o estabelecido nessa Estratégia, terrorismo, proliferação de armas de destruição em massa e crime organizado são as questões clássicas de segurança que devem estar inseridas na pauta da agenda interna e externa

14 No original: "We need a stronger Europe. This is what our citizens deserve, this is what the wider world expects. We live in times of existential crisis, within and beyond the European Union. Our Union is under threat. Our European project, which has brought unprecedented peace, prosperity and democracy, is being questioned. (...) The European Union will promote peace and guarantee the security of its citizens and territory. Internal and external security are ever more intertwined: our security at home depends on peace beyond our borders. (...) In a more complex world, we must stand united. Only the combined weight of a true union has the potential to deliver security, prosperity and democracy to its citizens and make a positive difference in the world. In a more connected world, the EU will engage with others. The Union cannot pull up a drawbridge to ward off external threats. To promote the security and prosperity of our citizens and to safeguard our democracies, we will manage interdependence, with all the opportunities, challenges and fears it brings about, by engaging the wider world. In a more contested world, the EU will be guided by a strong sense of responsibility. We will engage responsibly across Europe and the surrounding regions to the east and south. We will act globally to address the root causes of conflict and poverty, and to promote human rights".

15 Em inglês: European Security Strategy (ESS). 
da UE. Como temas não tradicionais, é possível encontrar as questões de "conflitos regionais" e "falência estatal", as quais foram securitizadas em uma perspectiva abrangente da concepção de ameaça (EUROPEAN UNION, 2003). Além disso, em um relatório lançado em 2008 sobre a implementação da ESE, o Conselho Europeu adicionou alguns assuntos às chamadas "ameaças-chave e desafios globais”: segurança cibernética, segurança energética, transformações climáticas, pirataria, armas pequenas e leves, munições de fragmentação e minas terrestres (EUROPEAN COUNCIL, 2008).

Com efeito, a distorção no funcionamento do Estado é uma causa primária de insegurança (HÄNGGI, 2004). Ademais, com a crescente globalização e transnacionalização das relações humanas, os conflitos regionais também se destacam como fonte de instabilidade para além dos limites geográficos do atrito. Isso não significa que tais assuntos sejam fenômenos novos no sistema internacional, mas sim que, dada a evolução das relações individuais, sociais, estatais e globais, no sentido da interdependência, torna-se difícil demarcar o alcance geográfico de determinadas questões.

Na busca de uma adequação da ESE aos desafios securitários mais recentes, a atual Alta Representante da União para as Relações Exteriores e a Política de Segurança (High Representative ou HR), Federica Mogherini, coordenou a elaboração da Estratégia Global da UE (EGUE) ${ }^{16}$, em junho de 2016, com o apoio da equipe do Serviço Europeu de Ação Externa (SEAE) ${ }^{17}$, criado para assistir o cargo de Alto Representante na condução e execução da política externa da UE. Pode-se dizer que a EGUE é uma releitura da ESE, porém, com foco ampliado: envolve toda a ação externa e interna da UE, desde o nível macro (global) ao micro (local). Na verdade, trata-se de uma tentativa da liderança de política externa da UE, enquanto ator internacional, para orientar as relações exteriores e a política externa da Europa em um contexto (geo)político cada vez mais exigente, tanto no nível nacional quanto no internacional (FRONTINI, 2016).

Em síntese, a Estratégia Global elenca os princípios que devem guiar tanto a ação externa da UE quanto as prioridades dessa: a) a segurança da UE; b) a resiliência societal e estatal ao leste e ao sul do continente europeu; c) a abordagem integrada frente a conflitos; d) ordens regionais cooperativas, e e) a governança global para o século XXI (EUROPEAN EXTERNAL ACTION

16 Em inglês: European Union Global Strategy (EUGS).

17 Em inglês: European External Action Service (EEAS). 
SERVICE, 2016a). Esses princípios-objetivos devem ser buscados por meio da mobilização de um vasto leque de políticas e instrumentos que devem ser promovidos pela EGUE, os quais devem ser executados em uma UE credível, responsável e conjunta, conforme a publicação já citada.

A EGUE trata-se, em última instância, de um manual de boas práticas em ambientes globais, regionais e locais, elaborado pela Alta Representante e sua equipe, e destinado aos Estados membros, como se fosse um chamado a esses para atuarem mais dentro do que fora da UE no que se refere a questões securitárias. Vale lembrar, entretanto, que o domínio securitário é mantido sob a prerrogativa intergovernamental, o que não vincula os Estados de modo jurídico. Assim, o Tratado da União Europeia (TUE) estabelece, no artigo 26, que cabe ao Conselho Europeu definir as linhas estratégicas da política externa da UE no que concerne à segurança. De qualquer forma, então, o peso das escolhas e dos interesses de cada Estado membro possui uma relevância que não pode ser ignorada.

\section{Setor de Segurança e Atividades de Reforma}

Não obstante a natureza intergovernamental da PESC, ela é tratada pela União Europeia como o instrumento que permite a ela falar e agir com uma só voz na cena internacional, sugerindo uma influência muito maior do que a influência de cada Estado membro individualmente. Nesse sentido, dentre os diversos instrumentos, políticas e estratégias inseridos na PESC, o conceito de reforma do setor de segurança aparece como um valor comum da ação externa da UE em sua atuação global (COMMISSION OF THE EUROPEAN COMMUNITIES, 2006). Enquanto ferramenta analítica, a SSR tem sido utilizada por atores de promoção do desenvolvimento e analistas sobre o tema ${ }^{18}$ para dar conta das atividades de reforma dos elementos do setor público responsáveis pela provisão de segurança externa e interna (HÄNGGI, 2004).

Conquanto a SSR esteja moldando cada vez mais os programas internacionais que afirmam prestar assistência ao desenvolvimento e à promoção da democracia,

18 Montanaro-Jankovski (2006) descreve que o conceito de SSR, per se, foi lançado pelo Departamento para o Desenvolvimento Internacional do governo do Reino Unido, no início dos anos de 1990. Por seu turno, Hänggi (2004) recorda que a maioria dos autores utiliza o termo "reforma do setor de segurança", mas outras expressões podem ser usadas com o mesmo sentido: a Organização para a Cooperação e Desenvolvimento Econômico (OCDE) prefere "reforma do sistema de segurança”, enquanto o Programa das Nações Unidas para o Desenvolvimento (PNUD) utiliza "reforma do setor de segurança e justiça”; já o termo "transformação do setor de segurança" tem sido aplicado no contexto africano. O presente estudo opta pela expressão sugerida por Hänggi (2004). 
ela é objeto de debate quanto aos seus objetivos. Para Hänggi (2004), a SSR é voltada à provisão efetiva e eficiente da segurança estatal e humana dentro de um quadro de governança democrática. Por outro lado, Montanaro-Jankovski (2006) defende a SSR como um instrumento específico de construção da paz (peacebuilding) que integra um amplo processo transformativo e estabilizador, mas não exclui os interesses estratégicos dos atores que a promovem. Em outro ângulo, Wulf (2004) acredita que somente as reformas promovidas no âmbito da comunidade de desenvolvimento podem ser enquadradas como SSR - as demais seriam interferências externas de Estados ou organizações com objetivos específicos.

Apesar da discussão sobre o conceito de SSR, é importante observar um fator de destaque nessa abordagem: a governabilidade, a qual exerce grande influência no funcionamento do setor securitário. Mesmo que a concepção de SSR escolhida não inclua elementos de alinhamento com normas democráticas e princípios de boa governança, é inevitável intuir que uma estrutura securitária eficiente depende do bom desempenho do governo, tanto em termos estratégicos quanto burocráticos. Um adequado aparato administrativo e burocrático de infraestrutura e de pessoal é essencial para a execução das atividades de segurança, do mesmo modo que a coordenação de estratégias de segurança pelos atores políticos responsáveis por isso.

A acepção de SSR sugere, na maioria das vezes, uma ligação ao compromisso normativo para a consolidação da democracia, tida como o regime político de melhor performance na política contemporânea - daí esse instrumento ser tão utilizado por organizações ditas promotoras do desenvolvimento, como a Organização para a Cooperação e Desenvolvimento Econômico, a Organização das Nações Unidas (ONU) e o Banco Mundial, por exemplo.

A ideia de SSR, portanto, está relacionada a um modelo ocidental de setor securitário, como indica Aguilar (2014):

A ONU verificou que os países onde o setor de segurança é eficaz apresentam algumas características comuns, como: a) um quadro legal e/ou constitucional que prevê a utilização legítima e responsável das instituições envolvidas, que atuam de acordo com mecanismos que sancionam o uso da força e definem seus papéis e responsabilidades, e de acordo com normas e padrões de direitos humanos universalmente aceitos; b) um sistema institucionalizado de governança e de gestão com mecanismos de direção e supervisão do setor de segurança, incluindo os sistemas de gestão financeira e análise, bem como de proteção dos direitos humanos; c) capacidades, ou seja, estruturas, pessoal, equipamentos e recursos suficientes; d) mecanismos de interação entre os agentes que permitem 
transparência, coordenação e cooperação entre os diferentes atores; e) a cultura de serviço, segundo a qual se promove a unidade, integridade, disciplina, imparcialidade e respeito aos direitos humanos entre os agentes de segurança (UN, A/62/659-S/2008/38, 2008). (AGUILAR, 2014, p. 51)

Em que pese posicionamentos críticos à expansão ou imposição de um modelo ocidentalizado de setor de segurança, é certo que um aparelho securitário doméstico é tão mais legítimo e aceito pela população quanto mais essa última pode fiscalizá-lo e participar da sua atuação, o que facilita a promoção da SSR. Logo, faz sentido afirmar que a SSR é um mecanismo de abrangência transversal com o objetivo de coordenação da criação, transformação e reforma das atividades ligadas ao domínio da segurança, de modo a torná-las mais eficientes, efetivas e sustentáveis (HÄNGGI, 2004). Por esse conceito, evidenciam-se os principais elementos da SSR:

a) a amplitude transversal, por ser um instrumento que afeta outras esferas além da securitária;

b) o foco da SSR, a coordenação de esforços em prol de mudanças;

c) o fato de que serviços de segurança podem ser criados, transformados e reformados através da SSR;

d) o resultado pretendido, que é conferir, em longo prazo, eficiência, efetividade e sustentabilidade ao setor de segurança.

Na mesma perspectiva, a UE estabelece em documentos conceituais os princípios e normas que devem permear o seu engajamento na SSR (COMMISSION OF THE EUROPEAN COMMUNITIES, 2006). Em regra, deve haver: uma apropriação nacional e regional do processo de reformas; uma avaliação dos requisitos essenciais de um sistema de segurança bem estruturado; um quadro que permita o enfrentamento de desafios securitários com base numa abordagem multissetorial; diálogo político, accountability e transparência.

Tendo em vista as diferentes abordagens que envolvem o conceito de segurança, torna-se necessário compreender o alcance do que se chama de "setor de segurança”. Em princípio, ele pode ser visto de duas maneiras. Por um lado, o conteúdo da SSR engloba as reformas de defesa, polícia, inteligência e justiça, num esforço de conduzi-las em conjunto, sob a mesma abordagem (HÄNGGI, 2004). Dependendo do ambiente em que é promovida, ainda pode se referir a questões de desarmamento, desmobilização e reintegração de ex-combatentes, justiça transicional, proliferação de armas leves ou pesadas e minas terrestres, entre outros. 
De outro modo, o setor de segurança pode ser visto sob uma perspectiva de governança, devido ao fator interveniente da governabilidade. Nesse caso, o sistema securitário incluiria as autoridades do poder público que estão relacionadas à prerrogativa de imposição da coerção, como os líderes do Poder Executivo, ministros, membros do Poder Legislativo e responsáveis pelas instituições judiciárias e de execução da lei (HÄNGGI, 2004). Além dessas forças estatutárias, outras forças não estatutárias são incorporadas nessa perspectiva, dada a sua essência de governança democrática: a sociedade civil, a mídia, instituições de pesquisa, organizações não governamentais e demais atores de governança não estatais.

Na promoção da SSR, a UE adota uma abordagem ampla e transversal de sistema ou setor de segurança, refletindo a natureza multidimensional da concepção de segurança, e tornando a SSR um instrumento importante na prevenção de conflitos, na construção da paz e no desenvolvimento sustentável. Dessa maneira, salienta-se que o foco da SSR não está nos serviços individuais, mas, sim, no funcionamento geral do sistema de segurança como parte da governabilidade do setor público. Logo, para a UE, o setor securitário envolve quatro esferas:

\section{Quadro 1. Definição de sistema de segurança pela União Europeia}

\begin{tabular}{|c|c|}
\hline \multicolumn{2}{|r|}{ O SETOR DE SEGURANÇA inclui: } \\
\hline $\begin{array}{l}\text { Agentes de segurança } \\
\text { essenciais, incluindo as } \\
\text { instituições de aplicação } \\
\text { da lei }\end{array}$ & $\begin{array}{l}\text { Forças armadas; polícia; guarda nacional; forças paramilitares; guar- } \\
\text { das presidenciais; serviços de inteligência; guarda costeira; guardas } \\
\text { de fronteiras; autoridades aduaneiras; unidades de segurança locais } \\
\text { ou de reserva. }\end{array}$ \\
\hline $\begin{array}{l}\text { Gestão de segurança e } \\
\text { órgãos de fiscalização }\end{array}$ & $\begin{array}{l}\text { Parlamento/poder legislativo; governo/poder executivo, incluindo } \\
\text { os ministérios da Defesa, da Administração Interna e das Relações } \\
\text { Exteriores; organismos nacionais de consultoria de segurança; auto- } \\
\text { ridades consuetudinárias e tradicionais; órgãos de gestão financeira; } \\
\text { sociedade civil, incluindo meios de comunicação, universidades e } \\
\text { ONGs. }\end{array}$ \\
\hline Instituições de justiça & $\begin{array}{l}\text { Ministérios de Justiça; prisões; serviços de investigação e repressão } \\
\text { criminal; o Judiciário (cortes e tribunais), serviços de implementação } \\
\text { de justiça (oficiais de justiça e diligências); outros sistemas judiciais } \\
\text { consuetudinários e tradicionais; comissões e ouvidorias dos direitos } \\
\text { humanos etc. }\end{array}$ \\
\hline $\begin{array}{l}\text { Forças de segurança não } \\
\text { oficiais }\end{array}$ & $\begin{array}{l}\text { Exércitos de libertação; exércitos de guerrilha; unidades privadas de } \\
\text { segurança pessoal; empresas de segurança privada etc. }\end{array}$ \\
\hline
\end{tabular}

Fonte: Commission of the European Communities, 2006, p. 5 (adaptado). 
É possível perceber, portanto, que o setor policial é entendido pela UE como uma instituição tanto de aplicação da lei quanto de justiça. A partir disso, compreende-se a inserção do setor policial como objeto de política externa da UE dentro do quadro estratégico de ação em SSR, o qual se refere a: 1) órgãos de gestão civil; 2) mecanismos de vigilância civil; 3) reforma da justiça; 4) aplicação da lei; 5) forças armadas; 6) apoio ao desarmamento, desmobilização e reintegração de ex-combatentes e combate a armas pequenas e leves; 7) construção de capacidade regional (COMMISSION OF THE EUROPEAN COMMUNITIES, 2006).

\section{Missões e Capacidades}

Continuando o esforço de delimitação conceitual de termos correlatos a este estudo, é preciso observar o significado mais adequado dos termos state-building, nation-building, capacity-building, peacebuilding e peacekeeping, a fim de se evitar uma provável confusão conceitual.

No entendimento ora discutido, é possível definir state-building como o conjunto intencional de ações para desenvolver a capacidade, as instituições e a legitimidade de um Estado, com vistas à consolidação do trinômio politics-polity-policy de forma efetiva, legítima e viável. Já a capacity-building, na perspectiva da UE, constituiria um subprocesso de state-building, com o objetivo de permitir que indivíduos, grupos, organizações, instituições e/ou países organizem seus próprios sistemas, recursos e know-how, para atingir seus objetivos de forma eficaz (GENERAL SECRETARIAT OF THE COUNCIL, 2014).

Por outro lado, nation-building ${ }^{19}$ seria uma espécie de subprocesso de formação e desenvolvimento de uma identidade nacional, que pode estar inserido no fenômeno de construção estatal ou não; afinal, é um processo importante, mas não condicionante à existência de um Estado - recorde-se que podem existir nações sem Estados (como a Palestina) e Estados com múltiplas nacionalidades (como a antiga Iugoslávia).

19 Na esteira disso, Dobbins et. al. (2008) sugerem que nation-building seria o uso da força armada na sequência de um conflito para promover uma paz duradoura e um governo representativo. É da opinião deste estudo que nada poderia ser mais confuso. O uso de força armada não indica a construção de identidade nacional, mas, sim, algum tipo de intervenção externa ou de peacemaking, a atividade de transformação de uma situação de conflito em uma situação de paz. Ademais, o conceito de governo representativo não exprime, igualmente, a existência de uma identidade nacional. 
Em outro espectro, peacebuilding e peacekeeping são denominadas atividades de paz e segurança promovidas por atores externos em uma região de conflito; via de regra, esses atores são a ONU e outras organizações internacionais. Enquanto peacebuilding pode ser conceituada, de modo geral, como a ação que objetiva reduzir o risco de surgimento de conflito, através do reforço das capacidades estatais em todos os níveis de gestão de conflito, peacekeeping é a ação, realizada com o consentimento das partes envolvidas, de preservar a paz após um conflito e auxiliar na implementação dos acordos de paz (GENERAL SECRETARIAT OF THE COUNCIL, 2014).

A partir dessa compreensão, a UE caracteriza as ações carreadas dentro do quadro da PCSD com conteúdo de SSR como missões civis, e não operações militares. Cabe destacar que, no jargão burocrático dos funcionários das instituições europeias, procedimentos de cunho civil são chamados de "missões", enquanto que os de cunho militar são tratados como "operações”. Tal diferenciação busca o distanciamento do conceito de "intervenções", isto é, atividades empreendidas por um Estado, um grupo dentro de um Estado, um grupo de Estados ou uma organização internacional que interferem coercitivamente nos assuntos internos de outro Estado (VINCENT,1974 apud ROBERTS, 1993).

No caso da intervenção militar, de fato, a distinção entre essa e uma operação militar, ao estilo do que a UE propõe, resta no fato de que a primeira, em última análise, sugere guerra, sendo, então,

uma questão de política internacional resolvida por meio do uso da força como forma de um ator dobrar a vontade de um outro (...) é uma forma de projeção de poder em que o objetivo político determina as metas, magnitude e duração de objetivos de engajamentos e operações de combate - conceito de tática - e a combinação de vários desses para um objetivo bélico que atenda ao propósito político de um ator - conceito de estratégia. (PROENÇA JUNIOR; DUARTE, 2003, p. 136-137)

Logo, as atividades até então aqui discutidas, com foco na SSR, possuem um objetivo claro de colaborar com a sustentação de um Estado, e não de intervenção militar ao estilo clássico de guerra. Não obstante, para que um Estado seja sustentável, ele deve possuir instituições domésticas minimamente efetivas ou, pelo menos, capazes de sê-lo.

Nesse ponto, o conceito de Tilly (2007) de capacidade estatal é adequado para a reflexão sobre as atividades de SSR em Estados da Bósnia-Herzegovina, 
Macedônia e Ucrânia, que passaram, ao mesmo tempo, por uma transição de regime político-econômico (socialista para capitalista) e por um processo de dissolução estatal (considerando o desmembramento da Iugoslávia e da União Soviética, respectivamente). Isso porque o conceito tillyano leva em conta como o contexto de guerra afeta o incremento das funções do Estado, ainda que em intensidade variável. Capacidade estatal significaria "a medida que as intervenções de agentes do Estado em recursos não estatais, atividades e conexões interpessoais alteram as distribuições existentes desses recursos, atividades e conexões interpessoais, bem como as relações entre essas distribuições" (TILLY, 2007, p. 16, tradução livre ${ }^{20}$ ). Em outras palavras, seria a habilidade que um Estado tem de implementar as suas decisões (a extensão de sua intervenção) e buscar os seus próprios interesses e a forma com que isso impacta na vida dos cidadãos.

De certo modo, é essa habilidade que é buscada, mesmo que de forma implícita, em qualquer missão de reforma das atividades relacionadas à segurança de um Estado. Essa capacidade estatal, latu sensu, pode ser desmembrada, então, nos vários setores da vida estatal. A capacidade policial, por seu turno, pode ser enquadrada como parte essencial de uma capacidade de regulação, visto que a polícia é a instituição com autorização estatal para o uso da força física, seja ela real ou por ameaça (BAYLEY; SHEARING, 1996).

Nas missões de SSR, busca-se, portanto, uma adequação dos setores de segurança a padrões de ação minimamente capazes de garantir a sustentabilidade estatal. Isso implica tanto a reformulação de setores e atividades quanto a criação de novas modalidades, o que é especialmente significativo em casos de Estados que passaram por transições e rupturas. Embora a fundação e preservação de estruturas institucionais constituam demandas urgentes no empreendimento de construção ou reconstrução estatal, seja ele feito pelos atores internos ou externos, tendo em vista a estabilização do sistema, sabe-se que nem sempre essa é a prioridade dos atores envolvidos. É o caso da Bósnia-Herzegovina, a qual se encaixa na observação de Cox (2001): em situações de reconstrução, "a resposta internacional à guerra civil frequentemente se centra na busca de novas estruturas constitucionais e instituições políticas" (COX, 2001, p. 05, tradução livre21). Os itens a seguir trazem indícios desse argumento.

20 No original: "State capacity means the extent to which interventions of state agents in existing non-state resources, activities, and interpersonal connections alter existing distributions of those resources, activities, and interpersonal connections as well as relations among those distributions".

21 No original: "The international response to civil war frequently centres on a search for new constitutional structures and political institutions”. 


\section{Missão de Polícia da União Europeia na Bósnia-Herzegovina - EUPM}

Durante o ano de 1990, a República da Bósnia compartilhava a agitação das demais componentes iugoslavas no sentido da desintegração. Após a declaração de independência de algumas repúblicas (Croácia e Eslovênia), a Bósnia-Herzegovina também proclamou sua independência da Iugoslávia, em 1992. A partir disso, o conflito político foi intensificado e tomou a forma de confronto armado entre bosniaks (bósnios de religião muçulmana), bósnios-croatas, bósnios-sérvios e as forças nacionais do que restou da Iugoslávia - em sua maioria, sérvios.

Apesar dos esforços de organizações internacionais e de atuações mais intervencionistas, como o papel desempenhado pelos Estados Unidos, o conflito durou três anos e apenas teve fim oficial com a assinatura do Acordo de Paz de Dayton, em 1995. Além de colocar um ponto final no confronto, tal acordo determinou a nova estrutura estatal do país, o que inclui a sua configuração político-administrativa. Atualmente, portanto, a BiH é caracterizada por uma estrutura descentralizada, que soma quatorze níveis de governo, o que explica a fragmentação do setor policial (MERLINGEN, 2009).

Entre 1995 e 1996, esteve em vigor a Implementation Force (IFOR), encabeçada pela Organização do Tratado do Atlântico Norte (OTAN), mas autorizada pela Organização das Nações Unidas (ONU), que visava garantir a continuidade da paz. Em 1996, o contingente da IFOR foi reduzido e ela passou a ser designada por Stabilisation Force (SFOR), que, no início, tinha características de uma missão de peacekeeping com foco no setor militar, mas que, posteriormente, começou a agir no setor de aplicação da lei, passando a ter um caráter mais de peacebuilding, intervencionista. A SFOR teve seu contingente gradualmente reduzido até que, em dezembro de 2004, foi substituída pela European Union Force Althea (EUFOR Althea), a maior missão da PESD até aquele momento, para supervisionar a implementação militar do Acordo de Paz de Dayton.

Entre o período de retirada da SFOR e de planejamento da EUFOR Althea, foi lançada a Missão de Polícia da União Europeia na Bósnia-Herzegovina, em 2002, com o objetivo de estabelecer mecanismos de policiamento sustentáveis, que deveriam estar de acordo com as práticas internacional e europeia (EUROPEAN EXTERNAL ACTION SERVICE, 2016b). A equipe dessa missão era formada por policiais de Estados membros da UE; porém, países que não faziam parte do bloco também puderam participar. Além disso, a equipe englobava um conjunto de civis internacionais e um grupo de funcionários recrutado localmente. 
A EUPM tinha um mandato inicial de três anos, mas seu fim foi prolongado duas vezes: a primeira foi até 2009; a segunda foi até 2012. Com foco na reforma do setor policial, teve como tarefas chave (EUROPEAN EXTERNAL ACTION SERVICE, 2012):

a) fortalecer as capacidades operacional e de ação conjunta das instituições de aplicação da lei que estivessem envolvidas no combate à corrupção e ao crime organizado;

b) acompanhar e auxiliar no planejamento e condução das investigações sobre esses crimes;

c) aumentar a efetividade do setor policial de forma geral.

Uma análise dos Relatórios de Progresso sobre a Bósnia-Herzegovina emitidos entre 2004 e 2015 (COMMISSION OF THE EUROPEAN COMMUNITIES, 2004; COMMISSION OF THE EUROPEAN COMMUNITIES, 2008; EUROPEAN COMMISSION, 2012; EUROPEAN COMMISSION, 2015) permite perceber um relato, quase que constante, de que houve dificuldades e atrasos na implementação das atividades e, consequentemente, da reforma. Assim, conforme afirmam Hadzovic, Krzalic e Kovacevic (2013), a reforma do setor policial não teve o sucesso esperado, mesmo que os documentos oficiais emitidos pela União Europeia sobre a missão tragam afirmações de que algum progresso foi feito. Um dos motivos que pode ser apontado é a falta de debate democrático sobre esse tema no país.

Além disso, a coordenação entre os 14 níveis de governo é um desafio enorme para a governabilidade desse "país", que ainda se encontra sob a administração internacional do Alto Representante da ONU. O Acordo de Dayton continua a sofrer violações constantes e ainda não foi implementado em sua totalidade. Some-se isso aos problemas gravíssimos de corrupção, capacidades estatais insuficientes e dificuldades econômicas e é possível começar a entender por que a EUPM é tida como um caso de insucesso da UE em termos de missões civis.

\section{Missão de Polícia da UE Proxima (EUPOL Proxima) e Equipe Consultiva de Polícia da UE (EUPAT)}

A República da Macedônia foi palco, em 2001, de um conflito armado entre o grupo National Liberation Army, daqueles de etnia albanesa, e as forças de segurança do governo da Macedônia. O objetivo central dos albaneses era sua desagregação do país para que fosse possível a construção de uma Grande Albânia. 
O conflito foi encerrado com a assinatura entre as partes do Acordo de Ohrid, ainda em 2001.

A atuação da União Europeia no país, a partir desse momento, incluiu a realização de duas missões civis de polícia, no âmbito de sua PCSD: a Missão de Polícia da UE Proxima e a Equipe Consultiva de Polícia da UE.

A EUPOL Proxima seguiu a conclusão da Operação Concordia, tendo sido iniciada em março de 2003, com vistas à garantia da implementação do Acordo de Ohrid. Seus objetivos específicos foram estabelecidos em torno do monitoramento, da orientação e do aconselhamento em questões relativas: à consolidação da lei e da ordem, incluindo a luta contra o crime organizado; à implementação de uma vasta reforma no Ministério de Assuntos Internos (MoI); à transição operacional e à criação de uma polícia de fronteira, como parte do esforço da UE para promover uma gestão fronteiriça integrada; à consolidação de uma relação de confiança entre polícia e população; e ao aumento da cooperação com os países vizinhos no campo do policiamento (COUNCIL OF THE EUROPEAN UNION, 2003).

Trabalhando em conjunto com a polícia nacional da Macedônia, os especialistas em policiamento da Proxima foram instruídos a focar seus esforços em ajudar no desenvolvimento de um serviço policial eficiente e profissional e, ao mesmo tempo, promover os padrões de policiamento europeus naquele país (COUNCIL OF THE EUROPEAN UNION, 2003). A estrutura da missão foi construída de forma a englobar policiais e civis internacionais com o auxílio de funcionários locais atuando em funções de apoio (IOANNIDES, 2009).

Com a finalização da EUPOL Proxima em dezembro de 2005, foi instalada a EUPAT. De acordo com a avaliação da UE, sua presença ainda se fazia necessária no país, principalmente nas áreas rurais fora de Skopje, para consolidar o progresso que havia sido conquistado nos últimos anos. O governo da Macedônia aceitou essa implementação com algumas condições, incluindo que a EUPAT tivesse uma orientação de reforma e não de estabilização; e que não fosse definida como uma “missão”, devido à crescente aproximação do país com a UE (IOANNIDES, 2009).

Os objetivos da EUPAT foram similares aos objetivos da missão anterior, centrados no desenvolvimento de um serviço policial profissional e eficiente, baseado nos padrões europeus de policiamento. O foco dessa segunda missão foi definido nas ações de monitoramento e assistência nas questões de fronteira, ordem pública, prestação de contas, corrupção e crime organizado, com atuação exclusivamente nos setores intermediários e superiores de gestão (EUROPEAN UNION COUNCIL SECRETARIAT, 2005). 
Com uma estrutura menor que a de sua antecessora, a EUPAT foi uma espécie de uma "missão de saída”, uma vez que se iniciava o processo de candidatura da Macedônia para adesão à União Europeia. Foi criado, então, um mecanismo de consulta para aproximar a UE e as autoridades locais, onde a EUPAT submetia relatórios de progresso mensais ao governo da Macedônia, até mesmo como forma de comprometer os governantes a honrar suas promessas e garantir a implementação de reformas (IOANNIDES, 2009).

Ambas as missões executadas na República da Macedônia estão entre as primeiras desse tipo realizadas pela UE e foram marcadas por dificuldades de planejamento e operação. Serviram, porém, para a aproximação entre o país e a UE, culminando no início do processo de adesão da Macedônia à UE, o que denota a existência de um aparato policial minimamente capaz de promover a segurança interna, tendo em vista que esse é um dos requisitos para a aprovação do status de Estado candidato a um país, dentro do contexto do processo de adesão à UE.

\section{Missão de Aconselhamento da UE sobre a Reforma do Setor de Segurança Civil - EUAM}

Na Ucrânia, a Missão de Assessoramento para a Reforma do Setor de Segurança Civil foi estabelecida pelo Conselho da União Europeia em julho de 2014, meses depois da deposição de um presidente eleito democraticamente e em um momento em que as forças securitárias civis ucranianas já não conseguiam dar conta da situação.

A missão foi estabelecida a partir de um pedido emitido pelo governo ucraniano e tem por objetivo ajudar as autoridades ucranianas a executar uma reforma sustentável do setor de segurança civil, através de aconselhamento estratégico e suporte prático a medidas de reforma específicas, com base em normas da UE e princípios internacionais de governança e direitos humanos.

Conforme entendimento da UE, o setor da segurança civil é composto por órgãos responsáveis pela aplicação da lei e pelo estado de direito, como o Ministério dos Assuntos Internos, a Polícia Nacional, o Escritório Nacional Anticorrupção, o Serviço de Segurança da Ucrânia, o Serviço Nacional de Guarda Fronteiriça, a Procuradoria Geral e tribunais locais, além dos papéis também desempenhados pela sociedade civil e pelo Parlamento da Ucrânia. 
Estando ainda em andamento, a EUAM conta com uma equipe de consultores internacionais que provém, principalmente, dos Estados membros da UE, com alta expertise em questões de segurança, polícia, poder judiciário, combate à corrupção, direitos humanos e comunicação pública.

A EUAM possui três pilares de atuação:

a) aconselhamento estratégico sobre a reforma do setor de segurança civil, em particular, a necessidade de desenvolver estratégias de segurança civis;

b) apoio para a implementação de reformas, através da entrega de aconselhamentos, treinamentos e outros projetos;

c) cooperação e coordenação, para assegurar que os esforços de reforma estão harmonizados com os atores ucranianos e internacionais.

Os assuntos de investigação criminal são uma prioridade dentro das atividades da EUAM. A ideia é reforçar a capacidade estatal de combater o crime e a corrupção, sendo um componente necessário à preservação do estado de direito. Atualmente, a Ucrânia carece tanto de uma abordagem estratégica para o setor como um todo, quanto de estratégias individuais de segurança civil.

Após a assinatura, pela Ucrânia, de um Acordo de Associação com a UE, a colaboração do governo com a EUAM passou para o topo da agenda governamental ucraniana, e a reforma do setor de segurança civil foi identificada como uma prioridade. Nesse sentido, o governo ucraniano tem tomado algumas medidas positivas no sentido da reforma, concentrando esforços em temas como o combate à corrupção e a reforma da polícia e do judiciário. No entanto, baixos níveis de confiança pública no sistema judicial, nos políticos e na aplicação da lei sugerem que muito ainda precisa ser feito para que as expectativas do público ucraniano sejam atendidas.

O tratamento específico do setor policial pela EUAM pode ser visto no estabelecimento e reestruturação da Polícia Nacional da Ucrânia, em novembro de 2015. As ações em andamento envolvem a realização de treinamento em desenvolvimento de liderança para os chefes de escritórios regionais de patrulha policial; uma série de workshops comunitários pilotos para os supervisores da Polícia Municipal de Kiev; treinamento de ordem pública para o novo sub-ramo especializado em ordem pública da polícia ucraniana, chamado Kord; e formação sobre os direitos de reunião pacífica para policiais em Lviv e Kharkiv. 
Até o presente momento, um dos projetos mais emblemáticos da missão é o desenvolvimento de um modelo de polícia de resposta para áreas rurais e pequenas cidades (suplementares à polícia de patrulha nas grandes cidades) que foi implementado pela primeira vez em Sambir (na região de Lviv) em 2015, antes de ser lançado para oito delegacias de polícia nas regiões de Kiev, Lviv e Kharkiv. Além disso, graças à EUAM, o conceito de policiamento comunitário, novo para a Ucrânia, foi estabelecido e está sendo implementado através do fornecimento de aconselhamento estratégico e treinamento.

\section{Conclusões}

A pesquisa apresentada neste estudo mostra indícios de que o framework de segurança que a UE oferece é um ponto de partida relevante para analisar o papel que ela pode exercer tanto na política global quanto em questões de segurança e defesa, especialmente em assuntos de reforma do setor de segurança nos países vizinhos.

Com efeito, se a dinâmica de interferência nas políticas domésticas de segurança dos Estados vizinhos for mantida, esse pode ser mais um exemplo que corrobora o argumento de que o papel que a UE irá assumir no cenário internacional dos próximos anos tende a ser o de um modelo normativo, embora isso não signifique um observador passivo das mudanças no sistema internacional. As reformas promovidas com vistas ao tratamento dessas questões nasceram de muitos ajustes políticos entre governo e legisladores, do lado doméstico; contudo, o papel normativo de atores externos, como a UE, precisa ser destacado no sentido de formatação de setores e atividades securitárias aos moldes ocidentais.

No entanto, é impossível desconsiderar a possibilidade de impacto da individualidade dos Estados membros nas decisões da PESC/PCSD. Como temas de segurança e defesa costumam ser caros à soberania estatal, e considerando que cada um dos Estados membros é autônomo para perseguir uma política externa própria nesses domínios - ainda que o alinhamento com a PESC seja desejável -, ainda restam dúvidas sobre o alcance da política externa da UE, consubstanciada em missões de SSR, na efetivação de capacidades estatais securitárias de Estados terceiros. 


\section{Referências}

AGUILAR, Sérgio Luiz Cruz. Reforma do Setor de Segurança: Teoria, prática e crítica. 1. ed. São Paulo: Editora Porto de Ideias, 2014.

BAYLEY, David H.; SHEARING, Clifford D. The Future of Policing. Law \& Society Review, Vol. 30, No. 3. (1996), pp. 585-606.

COMMISSION OF THE EUROPEAN COMMUNITIES. Bosnia and Herzegovina Stabilisation and Association Report 2004. COMMISSION STAFF WORKING PAPER \{COM(2004)205\}. Brussels, 2004, SEC(2004) 375. Disponível em: < http://www.uni-mannheim.de/ edz/pdf/sek/2004/sek-2004-0375-en.pdf > . Acesso em: 13 ago. 2016.

COMMISSION OF THE EUROPEAN COMMUNITIES. Communication from the Commission to the Council and the European Parliament: A Concept for European Community Support for Security Sector Reform. Brussels, 24.5.2006, COM (2006) 253 final. Disponível em: < http://eur-lex.europa.eu/legal-content/EN/TXT/?uri = celex\%3A52006DC 0253 > . Acesso em: 13 ago. 2016.

COMMISSION OF THE EUROPEAN COMMUNITIES. Bosnia and Herzegovina 2008 Progress Report. COMMISSION STAFF WORKING DOCUMENT \{COM(2008)674\}. Brussels, 05.11.2008 SEC(2008) 2693 final. Disponível em: < http://europa.ba/wp-content/up loads/2015/05/delegacijaEU_2011121405151330eng.pdf > . Acesso em: 13 ago. 2016.

COUNCIL OF THE EUROPEAN UNION. Council Joint Action 2003/681/CFSP on the European Union Police Mission on the Former Yugoslav Republic of Macedonia (EUPOL 'Proxima'). Brussels, September 29, 2003. Disponível em: < https://www. consilium. europa.eu/uedocs/cmsUpload/Council\%20Joint \% 20Action \% 202003 \% 20 681 \% 20CFSP.pdf > . Acesso em: 13 ago. 2016.

COX, Marcus. State building and post-conflict reconstruction: lessons from Bosnia. Geneva: Centre for Applied Studies in International Negotiations, 2001.

DOBBINS, James; et. al. Europe's role in nation-building: from the Balkans to the Congo. Santa Monica: RAND Corporation, 2008.

EEAS. European Union External Action website. 2016. Disponível em: < http://eeas. europa.eu/csdp/index_en.htm > . Acesso em: 13 ago. 2016.

EUROPEAN COMMISSION. Bosnia and Herzegovina 2012 Progress Report. COMMISSION STAFF WORKING DOCUMENT \{COM(2012) 600 final\}. Brussels, 10.10.2012 SWD(2012) 335 final. Disponível em: < https://ec.europa.eu/neighbourhood-enlargement/sites/ near/files/pdf/key_documents/2012/package/ba_rapport_2012_en.pdf > . Acesso em: 13 ago. 2016. 
EUROPEAN COMMISSION. Bosnia and Herzegovina 2015 Report. COMMISSION STAFF WORKING DOCUMENT. Brussels, 10.11.2015 SWD (2015) 214 final. Disponível em: < https://ec.europa.eu/neighbourhood-enlargement/sites/near/files/pdf/key_ documents / 2015/20151110_report_bosnia_and_herzegovina.pdf > . Acesso em: 13 ago. 2016.

EUROPEAN COUNCIL. Report on the implementation of the European Security Strategy: providing security in a changing world. Brussels, 11 December 2008. S407/08. Disponível em: < http://www.consilium.europa.eu/ueDocs/cms_Data/docs/pressdata/ EN/reports/104630.pdf > . Acesso em: 13 ago. 2016.

EUROPEAN EXTERNAL ACTION SERVICE. Common Security And Defence Policy: European Union Police Mission in Bosnia and Herzegovina (EUPM). Factsheet. Brussels, June 2012. Disponível em: < https://eeas.europa.eu/archives/csdp/missions-andoperations/eupm-bih/pdf/25062012_factsheet_eupm-bih_en.pdf > . Acesso em: 13 ago. 2016.

EUROPEAN EXTERNAL ACTION SERVICE. Shared Vision, Common Action: A Stronger Europe. A Global Strategy for the European Union's Foreign and Security Policy. June 2016. Disponível em: < http://europa.eu/globalstrategy/sites/globalstrategy/ files/regions/files/eugs_review_web.pdf > . Acesso em: 13 ago. 2016. (2016a).

EUROPEAN EXTERNAL ACTION SERVICE. EUPM/BiH Website. October 2016. Disponível em: < http://eeas.europa.eu/archives/csdp/missions-and-operations/eupm-bih/ index_en.htm > . Acesso em: 18 out 2016. (2016b).

EUROPEAN UNION. A Secure Europe in a Better World: European Security Strategy. Brussels, 12 December 2003. Disponível em: < https://www.consilium.europa.eu /uedocs/cmsUpload/78367.pdf > . Acesso em: 13 ago. 2016.

EUROPEAN UNION COUNCIL SECRETARIAT. EU Police Advisory Team (EUPAT) in the Former Yugoslav Republic of Macedonia. Factsheet. Brussels, December, 2005. Disponível em: < https://eeas.europa.eu/archives/csdp/missions-and-operations/ eupat/pdf/01122 005_factsheet_eupat_en.pdf > . Acesso em: 13 ago. 2016.

FERREIRA-PEREIRA, L. C. The Common Foreign and Security Policy of the European Union: The Anatomy of a Novel Process. Cena Internacional, 10(2), 2008, p. 37-54. FRONTINI, Andrea. The EU Global Strategy for Foreign and Security Policy: A Short Guide for the Perplexed. ISPI - Istituto per gli studi di politica internazionale. 12 Luglio, 2016. Disponível em: < http://www.ispionline.it/it/pubblicazione/eu-global-strategyforeign-and-security-policy-short-guide-perplexed-15441? platform $=$ hootsuite $>$. Acesso em: 13 ago. 2016.

GENERAL SECRETARIAT OF THE COUNCIL. Foreign Policy: key terms in 24 languages. Brussels: European Union, April 2014. 
HADZOVIC, Denis; KRZALIC, Armin; KOVACEVIC, Alma. Overview of Policing in Bosnia and Herzegovina. Center for Security Studies: Sarajevo, 2013. Disponível em: < http://css.ba/wp-content/uploads/2011/06/images_docs2_pregled \%20stanja \% 20 policije \%20u \%20bih_english\%20final.pdf > . Acesso em: 18 out. 2016.

HÄNGGI, Heiner. Conceptualizing Security Sector Reform and Reconstruction. In: BRYDEN, Alan; HÄNGGI, Heiner (eds.). Reform and Reconstruction of the Security Sector. Münster, Germany: LIT Verlag, 2004. Chapter 1, p. 03-18.

IOANNIDES, Isabelle. The EU Police Mission (EUPOL Proxima) and the European Union Police Advisory Team (EUPAT) in the former Yugoslav Republic of Macedonia. In: GREVI, Giovanni; HELLY, Damien; KEOHANE, Daniel. European Security and Defense Policy: The First 10 Years (1999-2009). Paris: The European Union Institute for Security Studies, 2009. Chapter 7, p. 187-199.

MERLINGEN, Michael. EUPM (Bosnia and Herzegovina). In: GREVI, Giovanni; HELLY, Damien; KEOHANE, Daniel (eds.). European Security and Defence Policy: The First 10 Years (1999-2009). Paris: The European Union Institute for Security Studies, 2009. Chapter 4, p. 161-172.

MONTANARO-JANKOVSKI. Security sector reform in the Balkans: a key to ending conflict. European Policy Centre Policy Brief, June 2006.

PROENCA JUNIOR, Domício; DUARTE, Érico E. Projeção de poder e intervenção militar pelos Estados Unidos da América. RBPI, Brasília, v. 46, n. 1, June 2003, p. 135-152. ROBERTS, Adam. Humanitarian war: military intervention and human rights. International Affairs (Royal Institute of International Affairs 1944-), Vol. 69, No. 3, (Jul., 1993), pp. 429-449.

RYAN, Barry J. The EU's Emergent Security-First Agenda: Securing Albania and Montenegro. Security Dialogue, vol. 40, no. 3, June, 2009, p. 311-331.

TILLY, Charles. Democracy. Cambridge: Cambridge University Press, 2007.

WULF, Herbert. Security sector reform in developing and transitional countries. Berghof Research Center for Constructive Conflict Management, 2004. 


\title{
Cooperação Internacional para o Desenvolvimento e Cooperação Sul-Sul: uma análise comparativa de seus princípios e desafios de gestão
}

\author{
International Cooperation for Development and \\ South-South Cooperation: a comparative analysis of \\ principles and challenges for management
}

DOI: $10.21530 /$ ci.v12n1.2017.632

Rosana Correa Tomazini ${ }^{1}$

\section{Resumo}

Os aspectos de gestão, no que compete ao regime de Cooperação Internacional para o Desenvolvimento (CID), têm ganhado destaque crescente nas agendas de organizações internacionais (OIs), tais como a Organização para Cooperação e Desenvolvimento Econômico (OCDE) e União Europeia (UE). Igualmente, a Cooperação Sul-Sul (CSS) executada pelo Brasil por meio da Agência Brasileira de Cooperação ( $A B C$ ) tem seguido a tendência de aprimoramento dos mecanismos de gestão de projetos. Diante de recursos escassos e sociedade civil cada vez mais informada, OIs ou países prestadores de cooperação têm assumido o desafio de perseguir melhores resultados em projetos e agendas de cooperação internacional, aprimorando os próprios mecanismos de gestão. Nesse contexto, o presente artigo propõe realizar uma análise descritiva e comparativa entre os desafios e aspectos da gestão da CSS, levados à cabo pela $\mathrm{ABC}$, do Ministério das Relações Exteriores, à luz dos aspectos de gestão adotados pelo Comitê de Ajuda ao Desenvolvimento, (CAD) da OCDE, e pela Direção-Geral da Cooperação Internacional e do Desenvolvimento (DG DEVCO), da UE.

Palavras-Chave: Cooperação Internacional para o Desenvolvimento, Cooperação Sul-Sul, Desafios de Gestão, Organizações Internacionais, União Europeia.

\begin{abstract}
1 Professora da Universidade Católica de Brasília. E-mail: rctomazini@gmail.com Artigo submetido em 12/02/2017 e aprovado em 13/04/2017.
\end{abstract}

Management aspects, related to the International Development Cooperation (IDC) regime, have gained increasing prominence in the international organizations (IOs) agendas, such as the Organization for Economic Co-operation and Development (OECD) and the European 
Union (EU). Likewise, the South-South Cooperation (CSS) implemented by Brazil, through the Brazilian Cooperation Agency (ABC), has followed the same tendency regarding the improvement of project management mechanisms. In a scenario of scarce resources and civil society progressively informed, IOs or States providing cooperation have assumed the challenge of pursuing better results in international cooperation projects and agendas by improving their own management mechanisms. In this context, the present article proposes to carry out a descriptive and comparative analysis between the challenges and aspects of CSS management, carried out by ABC, of the Ministry of Foreign Affairs, in the light of the management aspects adopted by the Development Assistance Committee (DAC) and the Directorate General for International Cooperation and Development (DG DEVCO), from the EU.

Keywords: International Development Cooperation (IDC), South-South Cooperation, Management Challenges, International Organizations, European Union.

\section{Introdução}

O presente artigo pretende realizar uma análise descritiva e comparativa entre os desafios e aspectos da gestão da Cooperação Sul-Sul (CSS) levados à cabo pela Agência Brasileira de Cooperação (ABC), do Ministério das Relações Exteriores do Brasil, à luz dos aspectos de gestão adotados pelo Comitê de Ajuda ao Desenvolvimento (CAD), da Organização para Cooperação e Desenvolvimento Econômico (OCDE); e pela Direção-Geral da Cooperação Internacional e do Desenvolvimento (DG DEVCO), da União Europeia (UE), no âmbito do sistema de Cooperação Internacional para o Desenvolvimento (CID).

Para tal, serão realizadas algumas reflexões iniciais sobre a CID e a CSS, e posteriormente referidas as três instituições anteriormente citadas quanto aos próprios mecanismos de gestão e acompanhamento de projetos, bem como desafios enfrentados nessa agenda. Assume-se que, no presente século, diante de recursos escassos e sociedade civil cada vez mais informada e participativa será necessário investir progressivamente e com mais rigor nos aspectos de gestão da cooperação internacional, assim como em mecanismos de prestação de contas à população.

Esclarece-se que, embora CID e CSS possam apresentar motivações e formas de execução distintas, como se verá, ambas pretendem colaborar com o desenvolvimento de países terceiros, e, por tal razão, entende-se que ambas compõem o regime de cooperação internacional para o desenvolvimento, justificando, assim, a análise comparativa que se pretende realizar. 


\section{Considerações iniciais sobre a Cooperação Internacional para o Desenvolvimento e a Cooperação Sul-Sul}

Aponta-se como embrião da Cooperação Internacional para o Desenvolvimento (CID) os incentivos financeiros oriundos dos Estados Unidos (EUA) à Europa, principalmente canalizados por meio do Plano Marshall, que tinham, principalmente, dois objetivos: o primeiro comercial/econômico, de reconstrução do continente europeu - e, portanto, da recuperação de relevante parceiro comercial - e, o segundo, geopolítico, de contenção da expansão do comunismo naquele continente (MARTINUSSEN; PEDERSEN, 2003). De forma a gerir os recursos oriundos do Plano Marshall, criou-se, em 1948, organização específica para tal, com foco na Europa, denominada Organização Europeia de Cooperação Econômica (OECE). Em 1961, a OECE dá lugar à Organização para a Cooperação e o Desenvolvimento Econômico (OCDE)², já contando com a participação dos Estados Unidos e Canadá, e ampliando o foco de atuação para outros continentes que não o Europeu.

No âmbito da OCDE, o Grupo de Assistência para o Desenvolvimento da OECE é substituído pelo Comitê de Ajuda ao Desenvolvimento (CAD), cujo objetivo inicial - que permanece até hoje - é o de "definir e monitorar padrões globais em áreas chave do desenvolvimento” (PORTAL OECD, 2016).

Assim, o objetivo da CID, de forma bastante ampla, diz respeito à promoção do desenvolvimento econômico e social de países menos desenvolvidos (denominados pelo CAD/OCDE como receptores), por meio de diferentes estratégias, que podem envolver transferência de recursos financeiros e/ou conhecimentos técnicos especializados, entre outros.

Alguns desafios expressivos da CID, ao longo de sua implementação, se referem tanto às formas de promoção dos diferentes aspectos do desenvolvimento, nos países receptores, como à definição e implementação de mecanismos de gestão que contribuam para incrementar a eficácia da cooperação, sendo este último aspecto o ponto focal deste artigo.

Relevante ressaltar que a CID se caracterizou, incialmente, pela verticalidade da relação entre doadores e receptores, aspecto criticado por países em desenvolvimento (PED), entre os quais o Brasil, que pretendiam estabelecer cooperação de caráter horizontal entre si, denominada posteriormente como Cooperação Sul-Sul (CSS).

2 Sigla em inglês: OEDC - Organization for Economic Development and Cooperation. 
Nota-se, contudo, que a expansão da CSS, iniciada nas décadas de 1950 e 1960, não é vista como um desdobramento da CID, mas como consequência do desenvolvimento dos PED em diversas áreas, tais como técnica, política e econômica, que, gradualmente, acabou por favorecer a cooperação internacional entre os mesmos (CORRÊA, 2010).

Seus princípios comuns de execução igualmente são distintos da CID, levada à cabo pelos países membros do $\mathrm{CAD} / \mathrm{OCDE}$, quais sejam: respeito à soberania dos PED; não interferência em assuntos internos nos países que recebem cooperação; horizontalidade (referem-se mutuamente como parceiros, e não como doador e receptor); e ganhos mútuos entre os cooperantes.

Outros aspectos que marcam o discurso da CSS referem-se à solidariedade e ausência de condicionalismos, como abaixo reforçado por Corrêa (2010).

Os operadores da cooperação entre países em desenvolvimento são enfáticos quando indicam a solidariedade como seu elemento motivador e desvinculado de interesses outros que não a promoção do desenvolvimento, posicionamento em contraponto às condicionalidades e direcionamentos que permeiam a ajuda oficial ao desenvolvimento dos países desenvolvidos. (CORRÊA, 2010, p. 91)

Tais características são aqui destacadas, pois a execução da cooperação prestada pelo Brasil se pauta, pelo menos no nível dos documentos e discursos oficiais, por tais princípios.

Acrescenta-se que a CSS não possui instituição de referência, como a OCDE, por exemplo, que sirva como polo aglutinador entre seus diversos atores. As estratégias, agendas e mesmo dados estatísticos sobre a CSS somente podem ser obtidos caso a caso, ou seja, junto aos atores protagonistas.

Por fim, uma última nota em relação ao desdobramento técnico da CSS, denominada como Cooperação Técnica entre Países em Desenvolvimento (CTPD), impulsionada pela criação, em 1974, de uma unidade especial no âmbito do Programa das Nações Unidas para o Desenvolvimento (PNUD), com o objetivo de subsidiar a cooperação técnica entre os PED. Em âmbito geral, as bases desse tipo de cooperação, estabelecidas no Plano de Ação de Buenos Aires, em 1978, focam o compartilhamento de expertise, tecnologia, recursos, entre outros aspectos, e igualmente se propõe a ser executada de forma horizontal e sem condicionalidades. ${ }^{3}$

3 Embora a CSS seja utilizada, por vezes, como sinônimo de CTPD, o presente artigo entende esta como aspecto técnico da CSS, sendo a CSS mais abrangente, incluindo diferentes modalidades de intercâmbio entre os PED, a saber: cooperação econômica, técnica, acadêmica, tecnológica, cultural e humanitária (Corrêa, 2010). 


\section{Reflexões iniciais sobre os princípios de gestão na Cooperação Internacional para o Desenvolvimento}

Logo após a II Guerra Mundial, acreditava-se que o desenvolvimento seria alcançado, principalmente, por meio do crescimento econômico com ênfase na intervenção do Estado, deixando outros aspectos do desenvolvimento, como o social, político ou institucional, em posição secundária, ou mesmo inexistente. Nesse cenário, a promoção do crescimento e desenvolvimento dos países receptores da CID foi caracterizada, inicialmente, por ações visando predominantemente transferências de recursos financeiros aos PED, com foco em projetos que apoiassem, por exemplo, a criação ou incremento de infraestrutura. Aspectos de gestão não eram devidamente considerados na execução de projetos ou programas de cooperação, pois acreditava-se que transferências de recursos financeiros a tais países seriam, por si só, suficientes para a promoção do crescimento econômico e, consequentemente, do desenvolvimento nos PED. Não foi.

Como consequência, na década de 1980, o Banco Mundial e o Fundo Monetário Internacional - organizações internacionais igualmente envolvidas na agenda da CID - passaram a observar e utilizar o termo "boa governança" para referir um conjunto de princípios sobre os quais projetos/ações na área deveriam se pautar para atingir os resultados propostos, notadamente para alcançar o desenvolvimento almejado ${ }^{4}$.

Embora não seja objetivo do presente artigo aprofundar o significado dos termos governança ou boa governança, a referência a esse último conceito é relevante, pois marca a preocupação das instituições internacionais envolvidas na CID, ou outras formas de cooperação internacional, sobre aspectos de gestão que pudessem melhorar a eficácia de suas ações. Some-se a tal preocupação a reflexão que se fortaleceu no início da década de 1990, no contexto do pós GuerraFria, sobre os aspectos sociais do desenvolvimento, bem como outras agendas das relações internacionais, como os direitos humanos, meio ambiente, entre outros temas, discutidos, por exemplo, nas diversas conferências organizadas

4 De acordo com o Banco Mundial, em seu documento Governance and Development, de 1992, governança "é a maneira pela qual o poder é exercido na administração dos recursos sociais e econômicos de um país visando o desenvolvimento", e boa governança seria definido como gestão saudável/sólida do desenvolvimento (sound development managment). Nesse contexto, os princípios que caracterizam a boa governança são: responsabilização/prestação de contas (accountability); participação; previsibilidade (predictability) e transparência. Disponível em: < http://documents.worldbank.org/curated/pt/604951468739447676/pdf/multipage.pdf $>$. Acesso em: 10 jan. 2017. 
pelas Nações Unidas, com destaque para a participação ativa da sociedade civil (LINDGREN, 2001).

$O$ resultado de tais conferências e engajamento internacional de diferentes atores contribuíram para reforçar um dos objetivos primordiais da CID: a redução da pobreza, culminando no estabelecimento de um conjunto de objetivos que deveriam ser adotados por toda a comunidade internacional (ou pelo menos pelos países signatários da Carta das Nações Unidas), denominados: Objetivos do Desenvolvimento do Milênio (ODM). Os ODM deveriam ser adotados a partir de 2000 e teriam sua vigência até 2015 , sendo posteriormente substituídos pelos Objetivos do Desenvolvimento Sustentável (ODS), hoje em vigor.

Uma das consequências imediatas do estabelecimento dos ODM foi a mobilização de diversos atores internacionais, entre os quais a OCDE, para a construção e estabelecimento de um conjunto de princípios e orientações que deveriam melhorar a efetividade da cooperação para o desenvolvimento ${ }^{5}$, cujos aspectos principais serão descritos no próximo tópico deste artigo.

\section{Aspectos de Gestão envolvendo o Comitê de Ajuda ao Desenvolvimento da OCDE}

Com efeito, aspectos de gestão, mais especificamente no que se refere à avaliação de projetos/ações da CID, se apresentou como um tema fulcral do CAD/ OCDE, desde o seu início. No primeiro relatório da presidência do Comitê, em 1962, por exemplo, o então presidente James Riddleberger afirmou que os membros dos governos deveriam dar mais atenção às avaliações de suas operações de ajuda e à troca de boas experiências na área, concluindo que a eficácia da ajuda seria uma das maiores preocupações do CAD no futuro (ORGANIZATION FOR ECONOMIC DEVELOPMENT AND COOPERATION, 2013, p.7).

Contudo, a preocupação com o tema se acentuou no início dos anos 2000, após a adoção dos ODM pela Assembleia Geral das Nações Unidas, como referido no tópico anterior, materializando-se em uma série de iniciativas/declarações internacionais, segundo as quais deveriam se pautar os atores da cooperação internacional para o desenvolvimento.

5 A efetividade da cooperação para o desenvolvimento, segundo o Fórum da "Parceria Global para a efetividade da cooperação para o desenvolvimento”, diz respeito a assegurar que todos os parceiros envolvidos no desenvolvimento coordenem o seu trabalho de forma a assegurar o máximo de impacto na erradicação da pobreza (PORTAL GLOBAL PARTNERSHIP FOR EFFECTIVE DEVELOPMENT COOPERATION, 2016). 
A Declaração de Roma de 2003, por exemplo, adotada naquele que ficou denominado como "Fórum de Alto Nível sobre a Eficácia da Ajuda", refletiu a preocupação das instituições bilaterais e multilaterais, na figura de doadores da CID, sobre a harmonização de políticas, procedimentos e práticas das instituições e seus países parceiros, de forma a aprimorar a efetividade da cooperação para o desenvolvimento e a implementação dos ODM (OEDC, 2003) ${ }^{6}$. A Declaração de Roma focou, igualmente, na necessidade de aproximação dos países receptores, prevendo dar a esses capacidade de liderarem e se apropriarem das ações a serem implementadas. O documento igualmente focava a necessidade de capacitação institucional dos países receptores, e, não menos importante, o engajamento da sociedade civil, incluindo o setor privado.

Destaca-se aqui a menção à necessidade de engajamento da sociedade civil, que já despontava como elemento de destaque na cena internacional, por exemplo, por meio do seu envolvimento nas várias conferências das Nações Unidas na década de 1990.

No ano seguinte, em 2004, em Marrakesh, foi reforçada a necessidade de se estabelecer a gestão focada nos resultados, com o intuito de atingir o objetivo de redução da pobreza e desigualdades de forma mais eficaz (OEDC, 2004). As discussões no âmbito da OCDE continuaram nesse sentido e, em 2005, adotou-se uma das mais emblemáticas declarações na área da CID, a Declaração de Paris (OEDC, 2006).

Tal declaração retomou os princípios da declaração de Roma, bem como identificou áreas específicas para o aprimoramento da ajuda: (i) necessidade de apropriação, por parte dos países parceiros, de políticas e estratégias de desenvolvimento; (ii) alinhamento, por parte dos doadores, com as estratégias nacionais de desenvolvimento, instituições e procedimentos dos países parceiros; (iii) harmonização entre as ações dos doadores, de forma a torná-las mais transparentes e eficazes; (iv) gestão centrada nos resultados; (v) corresponsabilização, por parte dos doadores e países parceiros, sobre os resultados obtidos no que se refere ao desenvolvimento (OEDC, 2006).

Houve detalhamento para cada uma das linhas de orientação, bem como o estabelecimento de metas, algumas quantificáveis, que deveriam ser atingidas até 2010. A Declaração de Paris reforçou a ideia de que o aumento do volume da

6 Houve preocupação, no início do milênio, sobre a variedade de processos e exigências, por parte dos doadores da CID, que implicavam, por exemplo, em elevados custos de transação e incompatibilidade de práticas por parte dos países recebedores (OEDC, 2003). 
ajuda deveria ser acompanhado, igualmente, pelo incremento de sua efetividade, de forma a alcançar os objetivos voltados para o desenvolvimento.

Nota-se que fizeram parte do Fórum de Alto Nível em Paris não só países membros da OCDE, além de outros países, organismos bilaterais e multilaterais, mas também organizações da sociedade civil (OSC), focando o aspecto da apropriação da declaração na necessidade de reforçar e fomentar a participação da sociedade civil e do setor privado na coordenação da ajuda, aspecto esse que se tornou irreversível na CID (OEDC, 2006).

Destacam-se, ainda, outras duas declarações, que caminharam no mesmo sentido que as anteriores: a Agenda de Ação de Acra, que igualmente reforçou a necessidade de participação da sociedade civil no desenvolvimento da CID, e a Parceria de Busan para a Eficácia da Cooperação para o Desenvolvimento, de 2011, que, entre outros aspectos, propôs: (i) um fórum global para o acompanhamento dos compromissos assumidos até então, denominado Parceria Global para a Efetividade da Cooperação para o Desenvolvimento7; (ii) mecanismos de monitoramento da ajuda; e (iii) reforçou a necessidade de parceria entre a sociedade civil e a iniciativa privada (OEDC, 2011).

Tais iniciativas tiveram o objetivo de dar novo significado para a agenda da cooperação para o desenvolvimento que ultrapassasse a mera relação entre países desenvolvidos do Norte (doadores) e países em desenvolvimento do Sul (receptores).

Para tal, ações complementares foram propostas, tais como: trabalhar em parceria com os governos locais; apropriação por parte dos PED das próprias prioridades de desenvolvimento, dando a esses países a responsabilidade de definir o modelo de desenvolvimento que pretendem seguir; foco em resultados e transparência das ações, participação de todos os envolvidos nas ações de cooperação, no sentido de estabelecer corresponsabilidades, entre diversos outros aspectos (OEDC, 2011).

Nota-se que, além do estabelecimento de princípios sobre os quais a CID deveria se pautar, houve incremento também de mecanismos de monitoramento sobre a execução e alcance de tais princípios. Nesse sentido, por exemplo, foram realizadas avaliações de acompanhamento sobre a implementação dos compromissos assumidos em Paris, nos países envolvidos, em 2006, 2008 e $2011^{8}$.

7 Em inglês: Global Partnership for effective development cooperation.

8 Para acesso às referidas avaliações consultar:

< http://www.oecd.org/dac/effectiveness/parisdeclarationandaccraagendaforaction.htm >. Acesso em: 01 jul. 2016. 
Por fim, destaca-se a avaliação dos pares realizada entre todos os membros do CAD/OCDE, de cinco em cinco anos, de forma a contribuir para a identificação de aspectos a serem melhorados nas estratégias de desenvolvimento adotadas por seus países membros, bem como permitir a troca de boas práticas. Tais avaliações renderam, como produtos palpáveis, além dos relatórios produzidos para cada país membro do $\mathrm{CAD}$, documentos de orientação em gestão, tais como: "Gerindo a Ajuda: Práticas dos Países Membros do CAD" ou "Gestão Efetiva da Ajuda: 12 lições das revisões dos pares do CAD" 9 .

Além dos diversos documentos de referência e avaliação da CID, o CAD/ OCDE propicia espaços de convivência e interação entre seus membros, tais como o Centro de Recursos de Avaliação ${ }^{10}$, rede que agrega gestores e especialistas em avaliação da cooperação para o desenvolvimento, de ministérios e agências de seus países membros e instituições multilaterais, com o objetivo de desenvolver e compartilhar boas práticas de avaliação, bem como contribuir para as diversas avaliações na CID.

No que se refere a dados/estatísticas, por exemplo, o CAD disponibiliza informações por país doador, receptor, setor, entre diversas outras combinações possíveis, representando base de dados de referência mundial, no que se refere à cooperação internacional para o desenvolvimento.

\section{Aspectos de Gestão envolvendo a Direção-Geral da Cooperação Internacional e do Desenvolvimento, da UE}

Antes de se iniciar a exposição dos principais mecanismos de gestão da UE, chama-se atenção para o fato de que a cooperação para o desenvolvimento é de responsabilidade compartilhada entre essa instituição e seus Estados membros. Isso quer dizer que a UE possui seus próprios programas/ações de CID, bem como seus EMs os possuem. Contudo, a própria UE deve coordenar esforços de forma a tornar os programas/ações existentes (na UE e nos EMs) complementares, o que, na prática, representa um dos grandes desafios do bloco.

No que se refere especificamente à UE, quem coordena as ações da CID é a Comissão Europeia (CE), órgão executivo da UE, e, dentro da CE, a CID é

9 Para acesso aos respectivos documentos consultar: < http://www.oecd.org/dac/peer-reviews/ > . Acesso em: 20 ago. 2016.

10 Em inglês: Evaluation Resource Centre DEReC. 
executada pela Direção Geral da Cooperação Internacional e do Desenvolvimento (DG DEVCO). Há que pontuar, igualmente, que com a criação do Serviço Europeu para a Ação Externa (EEAS) ${ }^{11}$, a DG DEVCO ganhou novo parceiro institucional interno, o que significa que a Comissão Europeia continua a executar a CID, mas o EEAS tem a responsabilidade de participação e codefinição política em tal execução ${ }^{12}$.

A UE, como membro do $\mathrm{CAD} / \mathrm{OCDE}^{13}$, segue igualmente as orientações das declarações referidas no tópico anterior, que têm, entre outros objetivos, como visto, o intuito de tornar as ações de cooperação mais eficazes, com maior impacto. No âmbito dessas orientações, a UE lançou, em 2007, uma coleção intitulada "Séries de Ferramentas e Métodos"14, que compila os instrumentos metodológicos produzidos pela direção de Qualidade de Operações da própria instituição. A coleção, disponível em formato digital, inclui uma série de guias, documentos de referência e documentos conceituais, com a finalidade de proporcionar conhecimento técnico e conceitual sobre as diversas fases da CID, além de prover informações práticas aos seus profissionais sobre sua implementação, bem como sobre os principais aspectos a se ter em conta nas diferentes fases do ciclo do projeto ${ }^{15}$.

A primeira publicação, por exemplo, foi lançada em 2004, e se refere ao guia de Gestão do Ciclo de Projeto, ainda em uso. Depois de 2004, várias outras publicações surgiram, compondo um acervo com mais de 40 referências $^{16}$.

No âmbito de tais publicações, merecem igualmente destaque os diversos instrumentos de avaliação e monitoramento que focam a análise de distintos aspectos de programas e projetos. Tais instrumentos podem estar voltados aos projetos, especificamente, ou aos seus instrumentos financeiros e documentos de país. Igualmente, as avaliações podem ser feitas por seus membros internos ou por avaliadores externos.

11 Sigla em inglês EEAS: European External Action Service - instituição criada pelo Tratado de Lisboa com a finalidade de executar a política externa da UE e possibilitar maior coerência em suas ações externas.

12 Nesse cenário, as duas instituições devem manter um diálogo constante, para que haja coerência nas ações internas e externas da UE. Na prática, tal coerência não é tarefa simples, pois são duas instituições robustas, com interesses ou formas de atuação, por vezes, distintos.

13 A UE faz parte do CAD da OCDE, bem como vários Estados membros.

14 Em inglês: Tools and Methods Series.

15 O ciclo do projeto compreende diversas fases, desde a concepção do projeto até a sua conclusão, a saber: identificação, concepção, implementação, avaliação, lições aprendidas.

16 Para ter acesso à lista completa de publicações consultar: < http://capacity4dev.ec.europa.eu/t-and-m-series/ minisite/list-available-publications > . Acesso em: 30 maio 2016. 
Ainda assim, há expressivo foco no monitoramento interno de projetos, de responsabilidade do gestor dos mesmos ${ }^{17}$, merecendo evidência o manual intitulado "Fortalecendo o Monitoramento Interno de Projetos - Como melhorar o papel do Gestor de Projetos" ${ }^{18}$, lançado em 2007, com orientações detalhadas e específicas sobre como proceder no monitoramento interno.

Do ponto de vista da UE, o gestor operacional do projeto é o responsável direto da instituição pelo seu acompanhamento e supervisão, de forma a colaborar para sua correta execução, prestação de contas e alcance de resultados. Ademais, a UE espera que os próprios gestores operacionais sejam igualmente capazes de atuar na concepção dos projetos, dos programas de cooperação, dos planos de trabalho, entre outras atividades.

Tal expectativa reflete a intenção de posicionamento mais ativo, por parte da UE, na execução da CID. Assim, não se trataria, somente, de transferência de recursos financeiros, ou conhecimentos técnicos, ou, ainda, de delegar a responsabilidade do alcance dos resultados aos beneficiários da cooperação, mas há intenção de comprometimento, por parte da UE, de igualmente assegurar a boa execução de seus projetos/programas, ainda que, na prática, tal tarefa assuma desafios de implementação.

No que se refere aos mecanismos externos de monitoramento, ou seja, o monitoramento realizado por avaliadores externos à UE, destaca-se o sistema de Monitoramento Orientado por Resultado (ROM) ${ }^{19}$, implementado de forma bastante detalhada, com foco em resultados ${ }^{20}$. Para realização do ROM são contratadas empresas externas, escolhidas por meio de editais públicos, com o objetivo de obter avaliações isentas de influências internas à instituição. O processo de avaliação incorpora a definição dos critérios de seleção dos projetos a serem monitorados, e é realizado nos locais de atuação dos mesmos.

No Brasil, por exemplo, as missões de monitoramento duram, aproximadamente, duas semanas, sendo feito contato com a delegação no Brasil e com os respectivos gestores de projetos, no início e no final das missões. Durante o tempo de estadia no país, os avaliadores externos visitam os projetos e mantêm diálogo intenso com

17 Gestor de projetos na denominação da UE/EC (European Comission) corresponde a: EC Task Manager.

18 Título original: Strengthening Project Internal Monitoring - How to enhance the role of EC task manager.

19 Sigla em inglês: ROM - Result Oriented Monitoring.

20 O ROM avalia, especificamente, cinco aspectos dos projetos: Relevância, Eficiência, Efetividade, Impacto e Sustentabilidade. Para detalhamento sobre o ROM consultar: < http://ec.europa.eu/europeaid/sites/devco/files/ methodology-tools-and-methods-series-strengthening-project-internal-monitoring-200706_en_2.pdf >. Acesso em: 20 jul. 2016. 
todo o seu público estratégico (stakeholders). Aqui cabe uma observação sobre o desafio que o avaliador enfrenta de obter uma visão completa dos projetos, em tão pouco tempo. A despeito da complexidade e abrangência do mecanismo ROM, o avaliador externo poderá ter dificuldades em identificar ou mensurar variáreis como "impacto" - no tempo em que a tarefa lhe foi designada -, o que representa um dos gargalos da CID, de forma geral. Em que medida ou como o projeto impactou os beneficiários-finais? Trata-se de uma pergunta, por vezes, de difícil resposta, pois os referidos impactos, frequentemente, somente poderão ser observados no médio e longo prazo.

Cita-se, ainda, como mecanismos de gestão, os relatórios semianuais de avaliação institucional, denominado "Relatório de Gestão sobre a Assistência Externa” (EAMR)21, cuja principal finalidade é controlar os desembolsos financeiros por parte das delegações da UE pelo mundo. Refere-se que os próprios projetos devem prever mecanismos de avaliação e monitoramento e, dependendo do valor do projeto, relatórios de auditoria realizados por empresa reconhecida pela UE.

Ademais, há preocupação crescente, por parte da Comissão Europeia, pelo menos por meio do discurso proferido e documentos de orientação publicados, em demonstrar aos próprios contribuintes (cidadãos da UE) o destino e resultados dos recursos alocados à CID. Tal preocupação pode ser ilustrada, por exemplo, por meio do lançamento recente, em julho de 2016, do primeiro relatório baseado em resultados alcançados pelos projetos e programas levados a cabo pela DG DEVCO 22 . Embora se possa criticar a forma sintética como os resultados são demonstrados, tal ação ilustra a tendência dos organismos internacionais envolvidos com CID na direta prestação de contas aos seus contribuintes/cidadãos.

Adensando a preocupação em alocar recursos de forma eficaz, o último documento de base para a Política de Desenvolvimento da UE, lançado em 2011, denominado “Agenda para Mudança”23, apresenta como objetivo primordial o aprimoramento do impacto e efetividade de tal política. O documento orienta a programação de 2014-2010 e exalta, entre outros pontos, a intenção de concentrar recursos e ações nos países que mais necessitam ou nos países mais pobres

21 Sigla em inglês: EAMR - External Assistance Management Report.

22 O relatório foca resultados selecionados, compreendendo projetos e programas financiados pela UE com países terceiros, entre meados de 2013 a meados de 2014. Relatório disponível em: < https://ec.europa.eu/europeaid/ sites/devco/files/eu-results-report-2016.en_.pdf > . Acesso em: 10 ago. 2016.

23 Mais informações sobre a Agenda para a Mudança (Agenda for Change) podem ser consultadas em < http:// ec.europa.eu/europeaid/policies/european-development-policy/agenda-change_en > . Acesso em: 15 jan. 2017. 
(o que não significa que a UE deixará de realizar cooperação com outros países em desenvolvimento, como o Brasil, mas, nesses casos, adotará distintas estratégias); coordenar esforços entre a UE e os EMs, de forma a evitar ações fragmentadas e de forma a potencializar resultados; necessidade de simplificar e tornar mais ágeis os processos dos programas e projetos de cooperação, ou seja, um conjunto de princípios voltados para aspectos da gestão da própria cooperação.

Sobre o papel das OSC, esse foi reafirmado no Tratado de Lisboa, devendo a UE, segundo tal Tratado, estabelecer um diálogo "aberto, transparente e regular" com tais organizações (UNIÃO EUROPEIA, 2007). Todavia, a UE já demonstra a necessidade de interação com as OSC, desde 2001, por meio, por exemplo, do seu "Livro Branco sobre Governança Europeia”, o qual propõe uma reforma na governança interna do bloco, de forma a tornar as próprias ações mais coerentes (no que se refere às interações entre suas diversas instituições) e legítimas (no que se refere ao incremento do diálogo com as OSC).

Quanto à implementação da CID, propriamente dita, a UE estabelece, por exemplo, a exigência de consulta às organizações da sociedade civil, e a outros doadores e intervenientes, antes dos editais de cooperação serem lançados em cada país parceiro, com o objetivo oficial de facilitar e complementar as ações desses atores (UNIÃO EUROPEIA, 2006).

Por fim, a UE possui um complexo serviço de estatísticas, denominado Eurostat $^{24}$, sobre os mais diversos aspectos do processo de integração, inclusive sobre a cooperação internacional para o desenvolvimento prestada pelo bloco, com manuais e cursos de capacitação de forma a facilitar o acesso à miríade de informações disponíveis.

\section{Aspectos de Gestão envolvendo a Agência Brasileira de Cooperação do MRE}

Inicialmente, refere-se que a cooperação técnica no Brasil se desenvolve em duas frentes distintas: cooperação horizontal (ou cooperação Sul-Sul) e cooperação recebida do exterior (bilateral ou multilateral), focando o presente artigo a primeira frente, ou seja, na CSS, executada pelo governo federal, cuja responsabilidade de gestão (coordenação, negociação, aprovação, acompanhamento e avaliação) é de competência legal da ABC.

24 Para acesso ao Eurostat, consultar: < http://ec.europa.eu/eurostat > Acesso em: 09 fev. 2017. 
A aparente carência de mecanismos de gestão da ABC, quando comparados aos anteriormente destacados, no âmbito da DG DEVCO, por exemplo, pode estar justificada na própria intenção ou princípios da CSS, como referido. Nesse sentido, Corrêa (2010) argumenta ser discutível a aplicação universal dos padrões de qualidade ou boas práticas definidos pelos países desenvolvidos para avaliar a eficácia e eficiência da cooperação prestada, pois, no caso da CSS, por exemplo, essa se coloca frente aos seus parceiros de forma horizontal, focando no "respeito mútuo à soberania dos parceiros e na não ingerência em assuntos internos” (CORRÊA, 2010, p. 94).

Nesse contexto, o aspecto da horizontalidade, como característica fulcral nas relações de cooperação entre os PED, parece se colocar como contraponto em relação à cooperação prestada pelos países desenvolvidos, representando a espinha dorsal de sua execução. Em complemento a tal observação, discussões ou estratégias que definam aspectos de gestão, por exemplo, parecem assumir posição secundária na referida agenda, cuja preocupação parece recair mais sobre os princípios - de solidariedade e horizontalidade - do que sobre a forma, ou seja, do que no aprimoramento dos próprios mecanismos de execução.

Contudo, ainda que a reflexão acima possa indicar que as estratégias adotadas pelo CAD/OCDE para incrementar a eficácia da cooperação, por meio do aprimoramento da gestão, por exemplo, possam ser intrusivas aos propósitos assumidos pela CSS, o fato é que, em 2013, a ABC lançou o seu primeiro "Manual de Gestão da Cooperação Técnica Sul-Sul” com o intuito de estabelecer orientações em diversos aspectos, tais como a concepção, negociação, aprovação, execução, acompanhamento e avaliação das ações executadas pelo Brasil, à luz dos mecanismos adotados pela CID, por exemplo. O documento traz ainda diversos exemplos de ferramentas de gestão de projetos, como, por exemplo, modelos de apresentação de relatórios, exemplos de indicadores de resultado, modelos de termos de referência, entre outros, reforçando a preocupação prática com o tema (BRASIL, 2013).

Nota-se que esse primeiro manual, com foco em gestão, foi lançado recentemente, em 2013, não havendo registro de outro documento, com tais características, lançado pela ABC, focando exclusivamente a $\mathrm{CSS}^{25}$.

25 Há, contudo, outros 3 manuais dirigidos à cooperação técnica: "Diretrizes para o Desenvolvimento da Cooperação Técnica Internacional - Multilateral e Bilateral (4 a edição lançada em 2014); Manual de Orientação para a Formulação de Projetos de Cooperação Técnica Internacional (2 a edição lançada em 2005); Manual Operacional da Cooperação Trilateral Brasil - Alemanha (2015). 
No que se refere aos mecanismos de avaliação ou monitoramento das ações implementadas pelo Brasil, o manual de 2013 traz indicações dos princípios e aspectos que deverão ser avaliados, não havendo outras referências disponíveis sobre tais mecanismos.

Sobre as estatísticas e banco de dados, aponta-se que, no caso da CSS, de forma geral, não há centralização de dados em alguma instituição, como há, por exemplo, no CAD/OCDE ou UE para a análise da CID. Nesse aspecto, segundo Corrêa (2010), os resultados são fragmentados, pois não há metodologia elaborada para sua quantificação, dado que suas especificidades são diferentes da CID. Esse aspecto, da falta de estatísticas centralizadas, dificulta, por exemplo, análise mais profunda dos impactos da CSS, ou mesmo de sua caracterização, de forma geral.

Todavia, apesar dos obstáculos quanto à disponibilização de estatísticas agregadas em base de dados única, por exemplo - o Instituto de Pesquisa Econômica Aplicada (IPEA), em conjunto com a ABC, tem, desde 2005, realizado mapeamento das despesas públicas da administração federal por meio dos relatórios sobre a Cooperação Brasileira para o Desenvolvimento (Cobradi). Até o momento, foram publicados três relatórios, referindo-se aos períodos de 2005 a 2009; 2010; e 2011 a 2013, com o propósito primordial de promover a divulgação e transparência da cooperação brasileira para o desenvolvimento. Segundo o prefácio do último Cobradi, lançado em 2016, referente ao período de 2011 a 2013, o governo brasileiro tem buscado aperfeiçoar a própria capacidade de gestão na área da cooperação internacional, incluindo demonstração de resultados, qualitativos e quantitativos (INSTITUTO DE PESQUISA ECONOMICA APLICADA, 2013).

Assim, observa-se a ampliação do escopo dos relatórios Cobradi com preocupações que transcendem a quantificação dos gastos do governo federal, expandindo a análise para aspectos de conteúdo, demonstrando práticas efetivas da cooperação prestada pelo país ${ }^{26}$.

Adicionalmente, é preciso referenciar dificuldades inerentes à CSS, advindas do incipiente marco regulatório, no que se refere à cooperação prestada pelo Brasil, que impossibilita, por exemplo, o país de atuar em áreas básicas da cooperação internacional, como contratação de serviços, aquisição de bens, remessas de recursos financeiros ao exterior, fazendo com que a $\mathrm{ABC}$ tenha que operar por

26 As modalidades de cooperação analisadas pelo Cobradi nos três relatórios já publicados são: cooperação técnica, cooperação educacional, cooperação científica e tecnológica, cooperação humanitária, apoio e proteção a refugiados, operações de manutenção de paz e gastos com organismos internacionais, ou seja, de ampla abrangência em relação aos diversos aspectos da cooperação prestada pelo Brasil. 
meio de agências internacionais, como o PNUD, por exemplo. Esse aspecto tem igualmente impacto na gestão da cooperação, pois implica, por exemplo, alta rotatividade de técnicos e analistas, contratados com frequência em regime de curta duração (RENZIO et al., 2013).

Ao referido incipiente marco regulatório, associa-se a ideia de que o Brasil deveria transformar a cooperação internacional prestada em política pública, de forma a aperfeiçoar suas leis e mecanismos de execução. Nesse sentido, segundo Ayllon (2012), o desafio para o país é instituir uma política pública de cooperação (e não uma política de governo), sustentável e duradoura, que se coloque acima dos governos de ocasião, ou de seus líderes políticos.

Por fim, no que tange à participação da sociedade civil na CSS, não há instruções específicas, por parte da ABC, sobre como tal participação deva ocorrer, embora o Manual de Gestão da Cooperação Técnica Sul-Sul, de 2013, traga algumas referências sobre a necessidade do seu envolvimento nos respectivos projetos $^{27}$. Igualmente, observa-se menção crescente às OSC nos três relatórios Cobradi já referidos, e a necessidade ressaltada nesses documentos de envolver tais organizações, tanto na execução como na concepção da cooperação.

\section{Análise Comparativa entre os aspectos e desafios de gestão do CAD/OCDE, DG-DEVCO/UE e ABC/MRE}

Antes de realizar a análise comparativa proposta, à luz dos aspectos até aqui referenciados, reforça-se que, embora as instituições aqui referidas, CAD/OCDE, DG DEVCO/UE e ABC/MRE, apresentem, por exemplo, estruturas, procedimentos, orçamentos, entre outros aspectos, distintos, destaca-se que a intenção aqui proposta é a de ressaltar os mecanismos, princípios ou documentos que refiram aspectos e desafios de gestão da cooperação internacional para o desenvolvimento no âmbito das respectivas instituições. Igualmente, não se pretende comparar os mecanismos ou ferramentas de gestão em si, analisando quais seriam mais apropriados do que outros, mas destacar a discussão que tem se intensificado, no âmbito do sistema internacional de cooperação para o desenvolvimento, sobre o aprimoramento dos aspectos de gestão, em perspectiva mais ampla.

Diante desse cenário, o CAD/OCDE, como visto, funciona, por exemplo, como fórum internacional aglutinador de orientações, tanto no aspecto de implementação

27 Nas cerca de 196 páginas do manual, a sociedade civil é referenciada apenas 3 vezes. 
da CID, quanto na tentativa de estabelecer mecanismos para tornar seus resultados mais eficazes. Nesse sentido, estabeleceu, por meio de suas declarações, uma série de princípios acordados entre seus membros, de forma a aprimorar a execução de projetos e ações na área. Funciona, igualmente, como instituição de referência para outros atores internacionais envolvidos na CID. Nota-se, ao longo da evolução de suas declarações, por exemplo, a consolidação de determinados aspectos, de forma a melhorar a eficácia da CID, tais como o envolvimento da sociedade civil na sua concepção e evolução, o fortalecimento das capacidades institucionais dos países receptores da cooperação, a recomendação de parcerias entre o setor público e privado, o incentivo ao estabelecimento de mecanismos de avaliação e monitoramento de projetos, bem como o desenvolvimento de aspectos de gestão de projetos, entre outros tópicos.

A forma como cada membro do CAD, ou cada ator envolvido na CID, seguirá tais orientações irá diferir. No caso da DG DEVCO, destacada nesse artigo, por exemplo, há igualmente evolução dos mecanismos da CID, seguindo os aspectos anteriormente referidos, e, muitas vezes, com mais detalhamento, por parte de seus executores. Nesse sentido, nota-se, por exemplo, extenso leque de orientações e publicações voltadas para a melhoria dos aspectos de gestão da cooperação. Da mesma forma, nota-se a relevância dada ao gestor do projeto como um dos responsáveis pelo sucesso na implementação de suas ações ou programas, ou seja, pelo cumprimento dos objetivos propostos e alcance de resultados, com estabelecimento de instruções específicas para o mesmo. Há, adicionalmente, mecanismos de avaliação estabelecidos tanto interna quanto externamente.

Claro, não cabe aqui analisar se tais mecanismos são, por si só, eficientes, ou cumprem, na totalidade, com os princípios propostos, mas cabe ressaltar que ilustram preocupação nos aspectos de gestão e execução dos projetos, bem como preocupação crescente com aspectos de responsabilização/prestação de contas (accountability), ou seja, na necessidade de prestar contas à população, em geral, sobre os resultados da cooperação.

Pode-se atribuir tal preocupação, igualmente, ao desenvolvimento das tecnologias da informação, que permitem, por exemplo, que um contribuinte com acesso à internet, por mais longe que esteja dos projetos de cooperação levados a cabo por seu país, tenha acesso (ou queira ter acesso) à base de dados ou à página web da agência responsável por tal cooperação, para melhor conhecimento sobre como são aplicados os próprios impostos pagos. 
Como justificar elevadas quantias financeiras destinadas aos projetos de cooperação internacional se os resultados desses não são de conhecimento da população, ou seja, dos contribuintes? Com tal preocupação, e diante de uma sociedade civil cada vez mais ativa e engajada, por exemplo, na Europa, a DG/ DEVCO tenta disponibilizar e dar visibilidade às próprias ações, por meio de diversas publicações, bem como por meio da exigência, feita aos países receptores da cooperação, de dar visibilidade aos projetos financiados pela UE. O aspecto da visibilidade, de alguma forma, materializa a cooperação da UE ao torná-la visível ao seu contribuinte, colaborando para a justificativa dos investimentos na área e, portanto, fortalecendo o aspecto da prestação de contas.

No que se refere à CSS, levada a cabo pelo Brasil, notadamente pela ABC, a despeito dessa cooperação se posicionar de forma distinta, como já apontado, aspectos de gestão têm igualmente merecido destaque. Nota-se, por exemplo, que a ABC lançou, recentemente, em 2013, manual voltado especificamente para a gestão da CSS, contendo diversos aspectos preconizados pelo CAD/OCDE, como, por exemplo, instruções específicas para monitoramento e avaliação, necessidade de focar projetos com maior alcance de resultados, ou do envolvimento da sociedade civil na concepção de suas ações - embora não haja instruções claras sobre como essa, por exemplo, poderia ou deveria ser envolvida.

Entretanto, quando comparamos o leque de ferramentas disponíveis no âmbito das referidas instituições, por exemplo, nota-se certa distinção. Mesmo no que se refere à compilação de dados e estatísticas, nota-se ausência de base de dados primária, centralizada na $\mathrm{ABC}$ ou em outro órgão federal, por exemplo, disponível para pesquisa; embora os relatórios Cobradi tenham igualmente o objetivo de fornecer dados para pesquisa na área. Nesse sentido, como já referido, o último Cobradi, relativo ao período de 2011-2013, ressalta preocupação que vai além de demonstrar apenas os gastos públicos com a cooperação prestada pelo Brasil, mas, igualmente, aborda boas práticas de cooperação, com o objetivo de disseminar os conhecimentos técnicos e científicos adquiridos.

Por fim, não menos importante, destaca-se a dificuldade estrutural da cooperação internacional prestada pelo Brasil, quanto ao incipiente marco regulatório, que tem como consequência imediata obstáculos práticos à sua execução (RENZIO et al., 2013). 


\section{Conclusões}

A agenda da CID tem evoluído, desde o pós II Guerra, demonstrando preocupação crescente não só com os próprios princípios norteadores, discutidos e definidos no âmbito do CAD/OCDE, mas com a implementação de tais princípios, notadamente no que se refere aos aspectos de gestão, de forma a incrementar o impacto dos resultados propostos nas suas diversas ações. Nesse sentido, atores do sistema internacional envolvidos com a CID, notadamente organizações internacionais, instituíram distintos mecanismos de gestão de projetos/programas de cooperação, de forma a potencializar resultados e investimentos realizados.

Da mesma forma, a CSS, no caso do Brasil, tem iniciado esforços nesse sentido, como demonstrado por meio de documentos publicados pela ABC e IPEA, como, por exemplo, o Manual de Gestão da Cooperação Técnica Sul-Sul, com o objetivo de aprimorar mecanismos de gestão; e os relatórios Cobradi, de forma a dar maior transparência à cooperação prestada pelo país.

Ainda assim, permanecem desafios a enfrentar, tanto na CID como na CSS. Nessa última, citou-se como desafios, por exemplo, a compilação de dados primários em base de dados digital; o envolvimento da sociedade civil nas discussões referentes à cooperação prestada; ou o próprio aprimoramento dos mecanismos de gestão. No que se refere à CID, por outro lado, embora haja abundância de documentos e mecanismos de gestão de projetos implementados, como visto no caso da DG DEVCO/UE, o desafio permanece quanto à mensuração e demonstração dos impactos dos projetos, por exemplo. Tantos documentos e orientações podem não significar, necessariamente, o aumento da eficácia da cooperação, embora ilustrem a preocupação material com tal agenda. Ademais, no caso da UE, há igualmente o desafio de compatibilizar e coordenar agendas internas, entre as próprias instituições e Estados membros que promovem a CID.

Relevante esclarecer que o presente artigo, ao dar destaque para instituições como a DG/DEVCO, por exemplo - ênfase essa justificada pela pluralidade de documentos e estratégias adotadas no aprimoramento da gestão de projetos de cooperação - não pretendeu afirmar que os princípios adotados por essa, à luz dos preceitos do CAD/OCDE, devam ser seguidos, sem restrições, por todos os atores da cooperação internacional para o desenvolvimento.

O que se pretendeu sinalizar, contudo, é que, no presente século, face ao crescente desenvolvimento tecnológico, ao acesso cada vez mais fácil à informação por parte da população, e diante dos recursos escassos e do aperfeiçoamento de 
mecanismos de gestão em diversas áreas, o aprimoramento do aspecto da gestão de projetos com foco em resultados parece ser tendência irreversível tanto na CID como na CSS.

\section{Referências}

AYLLÓN, B.P. Nuevos horizontes para los profesionales de las Relaciones Internacionales en Brasil - la Cooperación Internacional para el Desarrollo. Monções: Revista de Relações Internacionais, v. 1, n. 1, 2012, p. 208-224. Disponível em: < http://www. periodicos.ufgd.edu.br/index.php/moncoes/article/view/1827/1171 > . Acesso em: 20 jun. 2015.

BRASIL. Ministério das Relações Exteriores. Agência Brasileira de Cooperação. Manual de Gestão da Cooperação Técnica Sul-Sul/Ministério das Relações Exteriores, Agência Brasileira de Cooperação. Brasília, Ministério das Relações Exteriores, 2013. Disponível em: < http://www.abc.gov.br/CooperacaoTecnica/Manuais > . Acesso em: 20 ago. 2016.

CORREA, Marcio Lopes. Prática Comentada da Cooperação Internacional: entre a hegemonia e a busca de autonomia. Brasília, DF: Edição do Autor, 2010.

INSTITUTO DE PESQUISA ECONOMICA APLICADA; AGENCIA BRASILEIRA DE COOPERAÇAO. Cooperação brasileira para o desenvolvimento internacional: 2010. Brasília, DF: IPEA, 2013.

LINDGREN ALVES, J. A. Relações internacionais e temas sociais: a década das conferências. Brasília: IBRI, 2001.

MARTINUSSEN, John Degnbol; PEDERSEN, Poul Engberg. Aid: Understanding International Development Cooperation. London: Zed Books, 2003.

ORGANIZATION FOR ECONOMIC DEVELOPMENT AND COOPERATION, The DAC Network on Development Evaluation - 30 years of strengthening

learning in development, DAC Network on Development Evaluation, OECD: Paris, 2013. Disponível em: < http://www.oecd.org/dac/evaluation/Eval\%20history \% 20booklet \% 20 web.pdf > . Acesso em: 01 set. 2016.

ORGANIZATION FOR ECONOMIC DEVELOPMENT AND COOPERATION. Busan Partnership for Effective Development Co-operation. Coreia do Sul, 2011. Disponível em: < https://www.oecd.org/dac/effectiveness/31451637.pdf > . Acesso em: 12 ago. 2016. ORGANIZATION FOR ECONOMIC DEVELOPMENT AND COOPERATION. Declaracão de Paris sobre a Eficácia da Ajuda ao Desenvolvimento. França, 2006. Disponível em: < https://www.oecd.org/dac/effectiveness/38604403.pdf > . Acesso em: 10 ago 2016. 
ORGANIZATION FOR ECONOMIC DEVELOPMENT AND COOPERATION. Second International Roundtable on "Managing for Development Results". Marrakech, 2004. Disponível em: < http://www.oecd.org/officialdocuments/publicdisplaydocumentp $\mathrm{df} /$ ? cote $=$ DCD $/$ DIR(2004)4\&docLanguage $=$ En $>$. Acesso em: 10 ago 2016 .

ORGANIZATION FOR ECONOMIC DEVELOPMENT AND COOPERATION. Rome Declaration on Harmonisation. Itália, 2003. Disponível em: < https://www.oecd.org/dac/ effectiveness/31451637.pdf > . Acesso em: 10 ago. 2016.

PORTAL GLOBAL PARTNERSHIP FOR EFFECTIVE DEVELOPMENT COOPERATION. "What is development effective co-operation?", 2016. Disponível em: < http://effective cooperation.org/about/faqs/ > . Acesso em: 15 ago. 2016.

PORTAL OECD. “About DAC and DCD”, 2016. Disponível em: < http://www.oecd.org/dac/> . Acesso em: 20 ago. 2016.

RENZIO, Paolo et al. O Brasil e a Cooperação Sul-Sul: Como Responder aos Desafios Correntes. Rio de Janeiro: Brics Policy Center - Centro de Estudos e Pesquisa, 2013. Disponível em: < http://bricspolicycenter.org/homolog/uploads/trabalhos/5992/ doc/1619030609.pdf > . Acesso em: 01 set. 2016.

UNIÃO EUROPEIA.Regulamento (CE) No1889/2006 do Parlamento Europeu e do Conselho, de 20 de Dezembro de 2006. Jornal Oficial da União Europeia, Bruxelas, L 386/1, 29 dez. 2006. Disponível em: < http://eur-lex.europa.eu/legal-content/ PT/TXT/PDF/?uri = CELEX:32006R1889\&from = EN > . Acesso em: 30 maio 2015.

UNIÃO EUROPEIA. Tratado de Lisboa que altera o Tratado da União Europeia e o Tratado que institui a Comunidade Europeia, assinado em Lisboa em 13 de Dezembro de 2007. Jornal Oficial da União Europeia, Bruxelas, ano 50, C 306, 17 dez. 2007. Disponível em: < http://eur-lex.europa.eu/legal-content/PT/TXT/PDF/?uri = OJ:C:2007:306: FULL\&from $=$ PT $>$. Acesso em: 09 jun. 2015. 


\title{
T-TIP against the wall: feasibility, resistance, and consequences for third countries
}

\author{
T-TIP contra a parede: viabilidade, resistência \\ e consequências para países terceiros
}

DOI: $10.21530 /$ ci.v12n1.2017.590

Ana Paula Tostes ${ }^{1}$

\begin{abstract}
The objective of the article is to analyze the Transatlantic Trade and Investment Partnership (T-TIP) as a new model of international agreements, the reasons for resistance and the consequences for third countries that are dependent on trade with the United States and the European Union (EU). Special attention is given to the relationship between Brazil and the EU in the context of this new trend of trade partnerships. Using a theoretical approach based on neoliberal institutionalism (KEOHANE, 2005; KEOHANE, NYE, 1989, 2002), the article presents a historical overview of the transatlantic negotiations and a critical analysis of the innovative aspects it brings. Even considering the potential unfeasibility of the T-TIP, it must be understood as part of a new generation of trade and investments (BALDWIN, 2011, 2008). Similar to the Trans-Pacific Partnership, the North American Free Trade Agreement and the Comprehensive Economic and Trade Agreement, the T-TIP aims to introduce a robust regulatory framework that would affect multilateralism. These "big treaties" include commitments that are not covered by the World Trade Organization and mandates that are not traditionally attributed to international institutions. Therefore, they bring to light new elements in international trends that are yet to be fully understood.
\end{abstract}

Key-words: T-TIP, international relations, European Union, United States, Brazil.

\section{Resumo}

O objetivo do artigo é analisar o Tratado Transatlântico de Cooperação em Comércio e Investimento (T-TIP) como um novo modelo de acordos internacionais, revelando razões da resistência e consequências para os países terceiros que dependem do comércio com Estados Unidos e União Europeia (UE). O artigo foca a relação entre o Brasil e a UE no contexto

1 Pesquisadora Visitante na Universidade Livre de Berlim (ULB) e Professora Adjunta no Departamento de Relações Internacionais da Universidade do Estado do Rio de Janeiro (UERJ).

Artigo submetido em 25/11/2016 e aprovado em 28/03/2017. 
da nova tendência de parcerias comerciais. Utilizando uma abordagem teórica baseada no institucionalismo neoliberal (KEOHANE, 2005, KEOHANE, NYE, 1989, 2002), o artigo apresenta uma visão histórica das negociações transatlânticas e uma análise crítica dos aspectos inovadores que ela traz. Mesmo considerando a potencial inviabilidade do T-TIP, é relevante entender que se trata de um caso dentre outros que faz parte de uma nova geração de tratados de comércio e investimentos (BALDWIN, 2011, 2008). Semelhante ao Tratado de Parceria Transpacífico, ao Acordo de Livre Comércio da América do Norte e ao Acordo Econômico e Comercial Global, o T-TIP visa introduzir um marco regulatório robusto que pode impactar o multilateralismo. Esses "grandes tratados" incluem novos compromissos não incluídos na Organização Mundial do Comércio e competências que tradicionalmente não são atribuídas às instituições internacionais, logo trazem novidades pouco compreendidas sobre novas tendências de institucionalização internacional.

Palavras-chave: T-TIP, relações internacionais, União Europeia, Estados Unidos, Brasil.

\section{Introduction}

Since the adoption of the New Transatlantic Agenda (NTA) by Europe and the United States (US) in 1995, several initiatives on transatlantic cooperation between corporations and governments have been undertaken. Transatlantic Regulatory Cooperation (TRC) initiatives have made progress in reducing costs for businesses and consumers in a few sectors of the economy in both regions. When European and American leaders instructed the Transatlantic Economic Council to establish a new joint High-Level Working Group on Jobs and Growth (HLWG) in 2011, their goal was to identify and assess opportunities for strengthening transatlantic trade and investment relations, especially in areas with the highest potential in terms of job creation and growth. The main goal was to respond to the specific characteristics of transatlantic economic relations "by identifying policies and measures" to increase EU-US trade and investment flows to support "mutually beneficial job creation”, economic growth, and international competitiveness (HLWG Final Report, 2013). The main concern of the leaders heading the joint efforts was to minimize the impacts of the US crisis and the sovereign debt crisis in the Eurozone on inter-regional trade and the global economy.

The EU-US HLWG was founded to boost transatlantic trade and investment between the EU and the US, which were looking for a more "flexible" and "open-minded attitude" towards negotiations and the development of trade solutions. 
The HLWG's establishment, however, coincides with the emergence of new thinking in the wake of the failure of multilateral trade negotiations in the WTO Doha Round framework. The report of the Transatlantic Taskforce on Trade (TATF) emphasized the need for a new understanding of several aspects of the transatlantic relationship (COOPER, 2014). When we examine the Transatlantic Trade \& Investment Partnership Advisory Group Meeting Report (2014), it is not difficult to identify efforts to build closer relations between the two cultural, political, and economic world powers (Transatlantic Trade \& Investment Partnership Advisory Group Meeting Report. 2014). Since the 1990s, both US and European multinational companies have held divergent views on how to regulate markets for both goods and services, as these regulations are the principal barriers to transatlantic commerce. The main reason these companies seek to achieve greater harmonization in standards and regulatory procedures is to reduce costs imposed by having to comply with two different sets of regulations and standards. Regulatory cooperation is an umbrella concept that incorporates a broad range of activities. The acceptance of common principles and standards is seen as a key way to boost trade and investment between Europe and the US. This is exactly what was done within the EU to consolidate its common market (STUDY ON "EU-US HIGH LEVEL WORKING GROUP FINAL REPORT”. 2012).

Establishing rules at the regional level and monitoring compliance with them can foster a more favorable business climate by reducing uncertainties (KEOHANE, 2005). Institutional arrangements and commitments also help to reduce uncertainties and to save time. Furthermore, participation in regional institutions provides a more precise picture of what is important to partner countries, what the parties involved can expect from each other and how they can develop greater mutual trust (AXELROD, 1983). On one hand, compliance can be costly, as can the formulation of rules and new institutions beyond a certain point. On the other hand, however, in the case of heterogeneous populations and situations where preferences for policies and institutions differ from one group to the next, it is worth weighing the costs and benefits of certain integration policies (ALESINA, LA FERRARA, 2005).

Under Obama's administration the economic policy has addressed the establishment of high-standard rules for trade as a vital issue within the global economy. As one of the most ambitious efforts geared towards achieving convergence and aligning policies, the Transatlantic Trade and Investment Partnership (T-TIP) 
appeared as the biggest inter-regional initiative of its kind. Some even go so far as to call it the "agreement of the $21^{\text {st }}$ century" (BALDWIN, 2011, 2008). If we consider governance as formal and informal processes and institutions that guide and restrict collective action (KEOHANE, NYE JR, 2002), it is important for us to analyze the new trend in trade and investment agreements and how they affect global governance. Treaties such as the North America Free Trade Agreement (NAFTA), the Comprehensive Economic and Trade Agreement (CETA), the Trans-Pacific Partnership (TPP), and the Transatlantic Trade and Investment Partnership (T-TIP) are pioneering agreements due to the institutional innovations they bring and the commitments made by member states.

According to Baldwin (2011), there is a new generation of treaties that introduce strong regulations, expand negotiations to new sectors and will have strong impacts on third countries. The scope of these "big treaties" go beyond commercial relations between countries and can affect civil society and domestic policies. While there are many innovative commitments in the new generation of trade and investment treaties that deserve to be broadly explored, the scope of this article will be limited to the history of the T-TIP and the most important and controversial issues to be agreed upon by the member states. A critical overview of the potential impacts of the T-TIP on the institutional level can help understand the consequences of other treaties of a similar magnitude, such as the TPP, CETA, and NAFTA. It is worth highlighting that one of the most controversial issues is the inclusion of a mechanism to settle conflicts that may emerge over the rights and duties agreed upon in the treaty: "investor-state dispute settlement" (ISDS). ${ }^{2}$ ISDS systems generally have full jurisdiction over conflicts and do not allow for any interference from or reviews by the national courts of member states. The ISDS would help investors overcome difficulties they face when their country of origin does not find it politically expedient to bring their case before the International Court of Justice. However, it means that the investors would have full guaranties for their investments, whereas civil society has none regarding the commitments of the investors. Furthermore, the US and the EU are so important economically to third countries that direct cooperation between the two regions will necessary impact the economies of other states.

2 This is a type of international arbitration and an instrument of international public law used in other bilateral and multilateral investment treaties (NAFTA, for example) in which disputes and debts are settled without any interference from national legal institutions. 
Ruggie (1992) defined multilateralism as a system of general principles and rules in which there is no discrimination between states. Based on this definition, in a multilateral world, global institutional frameworks are expected to treat all states equally. One would not expect discriminatory mechanisms that establish special benefits for a small group of countries to be adopted. The analysis of the new wave of "big treaties" provides a critical view of the risks that the alignment of powerful states' trade and investment interests in a comprehensive agreement pose for multilateralism.

The objective of the article is to analyze the T-TIP as a new model of international partnership, while explaining criticisms and reasons for support and rejection of innovative rules and commitments included in the agreement. Even though Donald Trump's victory in the US may mean the death of the T-TIP, the article aims to present the origins of the transatlantic negotiation in the context of a critical interpretation of the innovative rules emerging in the new trend of multilateral and bilateral trade and investment treaties. For this study, a theoretical approach based on neoliberal institutionalism (KEOHANE, 2005; KEOHANE, NYE, 1989, 2002) was adopted. As the potential impacts of these treaties on third countries and multilateralism in general are quite significant, we will examine in more detail the relationship between the EU and Brazil and other BRICS countries. The article begins by presenting a historical overview of the interests and goals of the parties of the treaty in which the context and challenges of the US-EU relationship during negotiations are highlighted. Here, we introduce a few issues and sticking points of the T-TIP in order to better understand the innovative aspects of the new generation of trade treaties. In the second part of the article, we will discuss the uncertain future of the T-TIP and its implications for Brazil-EU relations.

\section{The US and EU partnership and the challenges on the road}

As has already been mentioned, the U.S.-EU relationship is the largest in the world. It makes up nearly half of global GDP. We trade about \$1 trillion in goods and services each year. We invest nearly $\$ 4$ trillion in each other's economies. And all that supports around 13 million jobs on both sides of the Atlantic. And this potentially ground breaking partnership would deepen those ties. It would increase exports; decrease barriers to trade and investment, as part of broader growth strategies in 
both our economies. It would support hundreds of thousands of jobs on both sides of the ocean. (...) I can tell you that it has been warmly received in the U.S. as well, both in our Congress and in our business community. (...) America and Europe have done extraordinary things together before and I believe we can forge on economic alliance as strong as our diplomatic and security alliances - which, of course, have been the most powerful in history. (...) This Transatlantic Trade and Investment partnership is going to be a priority of mine and my administration. (...) it has to be part of a comprehensive strategy that we pursue on both sides of the Atlantic. (THE OBAMA WHITE HOUSE, 2013) 3

The US and the EU are the two big centers of power of the West, although the economic crisis is still around. Together, the US and the EU already retain the largest bilateral trade and investment relationship in the world, roughly $31 \%$ of the world trade and over $49 \%$ of the world GDP, representing a trade of about \$1trillion in goods and services each year, an investment of nearly \$ 4 trillion in each other's economies, and all that supports around 13 million jobs on both sides of the Atlantic. In his statement of 2013, President Obama made clear the US position for strengthening the transatlantic partnership: First, Obama himself appeared engaged in this project. Second, he tried to send the message that the Presidency, the Congress and the business community are all interested in the T-TIP; in other words, it seemed that there was no domestic conflict about the whole intention to overcome potential sensitivities to achieve the T-TIP at that time. Third, the trade and investment alliance seemed as the continuity of the military and defense alliance that resulted in the NATO. Also, President Obama attested in his talk that diplomatic and security strategies were clearly proved as close and related by the historical cooperation between the two regions.

Indications of the US government's intentions appeared once again in one of Obama's last international moves to get the T-TIP approved. In his visit to Berlin in November 2016, Obama and German Chancellor Angela Merkel discussed transatlantic cooperation and Russia in the immediate aftermath of Donald Trump's election victory one month earlier. According to Obama and Merkel, "the future is already happening and there will not be a return to a world before globalization" and "Germans and Americans have to seize the opportunity to shape

3 This is part of the President Obama's statement on the Transatlantic Treaty for Trade and Investment partnership in Lough Erne, Northern Ireland in June $17^{\text {th }}$, 2013. The announcement was about the first round of the Treaty negotiations to have place in Washington on July $8^{\text {th }} 2013$. 
globalization according to their values and ideas" (MERKEL, OBAMA, 2016). The leaders launched a joint appeal in defense of the T-TIP in the Germany weekly WirtschaftWoche:

Negotiations started three years ago and, considering the complexity of these issues, have made solid progress. An agreement that knits our economies closer together, based on rules that reflect our shared values, would help us grow and remain globally competitive for decades to come. Today, many U.S. and European companies and employees already benefit from transatlantic trade and investments. Global markets and production chains are increasingly intertwined. We realize that decisions in one country have tangible effects in others. To meet all these challenges, we need rules that are currently being negotiated in the framework of T-TIP. (MERKEL, OBAMA, 2016)

This clearly illustrates how much energy President Obama put into this transatlantic cooperation initiative. He seemed convinced right until his final days in office that this project was of utmost importance to the US, especially considering the international crisis and China's growing power in a global scenario marked by uncertainty. China's position was confirmed by its investments in infrastructure in Russia: a few projects are still under negotiation, such as the Russia-China gas pipeline, a deep-water port in Crimea, and a railway system in Russia's Far East. By building closer relations with Russia, Kazakhstan, and Belarus, China is placing its bets on these relations serving it well in the future - a strategy supported by the current Chinese foreign ministry.

While other economic and political powers were seeking new joint ventures in the East, Merkel and Obama were big supporters of the negotiations to build a transatlantic free trade and investment corridor. Since 2013, the US and the EU have held ten rounds of negotiations; the first was in Washington, D.C. between July 8 and 12, 2013. The complexity of the negotiations, their scope and scale, and the number of sectors and policies covered under the ambitious trade agreement affect the progress of ongoing talks. That said, the goal of building closer investments and trade relations was not merely a result of the crisis. In fact, for most trade agreements, it has taken much longer than a couple of years to conclude negotiations. The scale of the T-TIP in particular is too large to be achieved in a short period of time. To add to this, both partners have faced new security issues recently. The long duration of such a negotiating process could 
be extended even further in light of changes in government, such as the election of Trump in the US. In the case of Angela Merkel, although she is favored to win Germany's upcoming elections, she still has to go through the democratic process of electing the new Chancellor in 2017.

While EU institutions have already approved the T-TIP, some EU member states were still uncomfortable with the bilateral agreement. On the other side of the ocean, the new US president committed to not signing the treaty during his campaign. In this context, however, we still consider the strength of the bilateral relations between the US and the EU as well as its consequences to the global trade beyond the Trump administration. It is important to understand the complexity of implementing the T-TIP from different points of view, especially as similar institutional innovations exist in NAFTA and CETA, which are still in effect - or, at least, as of now they are.

\section{What's new and why does it matter?}

Between 1980 and 1990, regionalist initiatives took on new characteristics and scope. The pursuit of market liberalization with the goal of reducing costs by strengthening cooperation between the member states of the agreements generated what is known as "open regionalism". In other words, contrary to "closed regionalism" of the past, a new phase of trade cooperation appeared in 1980s. The "open regionalism” entailed expanding not only partnerships among, but also the sectors involved in cooperation (FAWCETT, HURRELL, 1995). The context of the emergence of the "open regionalism" can be explained by the rise of neoliberalism, which promoted the reduction of state interference and greater market liberalization, with greater freedom to sign different kinds of agreements with various objectives as well as the emergence of a greater number of international institutions.

According to Fawcett and Hurrell (1995), in addition to the considerable variations in the level of institutionalization of the second wave of regionalism, its multidimensional nature makes it difficult to draw a clear line between the economy and politics. The proliferation of Preferential Trade Agreements (PTA) and international institutions in 1990s became crucial frame of emerging trust and predictability among the states and other international actors (KEOHANE, 1989). The significant growth of regional agreements has been interpreted as a 
"third wave of regionalism" in the context of the enhance of the interdependence among markets and states.

Baldwin (2011) identifies a complex relation known as the "trade-investment-service nexus", which arose from the new global value chains (GVCs). The complexity of the globalized world required new ways of cooperation and a search for greater institutionalization of standards and rights that affect gains in international trade. The scenario of the new GVC is the key for understanding the commitment of economic partners such as the EU and UE to broaden the scope of predictability in their trade relations. The globalization motivates the economic groups to operate internationally so they frame their activities through outsourcing and offshoring of their activities. International production, trade and investments are organized in different stages of the production. The whole process of production (from raw materials to finished products) and services are carried out wherever the necessary skills and materials are available at competitive costs and quality. The OECD has highlighted the broad range of policy implications of the GVCs.

Neoliberal institutionalism has dedicated to framing explanations about the emergence of the liberal order and the sophistication of international institutions in the post war world. The strategic interests of the Companies under the new GVCs can also be understood as rational choices. The production process is located in different countries, then regional agreements about broader issues can help to reduce costs and time in trading.

The implication of the new trade and investment treaties, however, is not only limited to the partners. In order to better understand the differences of the impact of existing commitments in the new trade and investments treaties as possible threat to multilateralism, Horn, Mavroidis, and Sapir (2009) developed a classification of the new anatomy of regional rules. According to the authors, to understand the new elements introduced by the mega-treaties, one must differentiate between the commitments they contain and the norms and rules of the WTO - that is, those that establish standards already recognized by the multilateral system of norms, called "WTO in" (or intra), and new kinds of commitments that end up prevailing in these cases. In the new trade and investments treaties, in addition to the WTO in-intra norms, one finds commitments that extend the deadlines or the scope on areas and issues beyond what has already been established by WTO norms. The new norms are referred to by the authors as "WTO plus". In these cases, deadlines can be extended or issues referring to obligations or rights already agreed upon 
at the WTO are included. Yet, the most notorious innovation is the expansion of commitments that are not contemplated or regulated by the WTO - classified as "WTO extra" (or "WTO-X"). The WTO extra-X norms include both new rules and new areas of negotiation; investment rules on new issues in the agreements; the definition of new procedures; as well as new principles and rights that involve relations at the country level. Thus, when we consider the international relations as an arena of collective actions, it is possible to understand the aim to enhance commitments by institutionalizing rule related to trade interests of powerful international actors. However, as much as new trade commitments are out of the WTO, the third countries have no access to participate on the establishment of the new trade rules. In other words, once new regulations are decided between strong markets such as the US and EU, the third countries depending on trading with the US and EU will have to follow all new rules and standards - even if they did not make part of the agreement.

\section{The sticking points and actors}

Although the content of the T-TIP and TPP negotiations has not been officially released to the public to protect national interests, the treaties' texts have been leaked several times. As the extent of the treaties and their political and legal impacts on the domestic level are now known, the societies of many countries involved have expressed dissatisfaction with the lack of transparency and the extensive nature of the agreements. There are concerns about how much these new models of regional integration have the potential to profoundly alter the development of global trade and affect multilateralism, as detailed above. In addition, their impacts will be felt not only internationally, but also domestically.

First, the new generation of trade and investment treaties could operate a real free trade zone, since the treaties aim to eliminate or substantially reduce barriers to the circulation of goods, services, and investments impacting societies and small business. Second, they cover new policy issues beyond trade, such as: intellectual property, labor laws, common environmental actions, etc. In this case, several typically domestic issues would escape from national institutions to be created. Finally, and maybe the most important, the new investment treaties create a legal framework for resolving disputes. It means that rather than creating certainty for foreign investors and states, the process of resolving investments 
disputes through arbitration has created uncertainty about the meaning of those tights and public international law. In other words, public international law rights have been articulated for the first time in investment treaties (FRANCK, 2005).

Even considering different points of view, it is still easy to understand why the T-TIP is less about trade than about increasing the power of corporations and making trade easier and cheaper (KHORAMA, 2015). The Treaty would lead to lower tariffs and therefore to lower income for states, though not to a very significant extent because tariffs are already quite low. Thus, removing remaining tariffs is expected to have very limited effects. "Therefore the focus of negotiating and modeling efforts is on non-tariff measures (NTM'S), or non-tariff barriers. These are procedures, laws and regulations other than tariffs or quotas that impede trade in goods and services between two countries." (RAZA et al., 2014, p. 41). In this context, since 2013 negotiating groups have set out respective approaches and ambitions in as much as twenty various areas that the T-TIP is set to cover. The negotiators met with 350 stakeholders to listen to formal presentations and answer questions about cutting differences in technical regulations, standards and certification.

Currently, the volume of trade between the EU and the US is already the largest in the world. Even so, transoceanic trade often costs companies' time and money: for example, when a car is approved in the EU, it has to undergo new safety tests in the US. The T-TIP was expected to reduce such costs and make products and services less expensive. It is too early to evaluate the impact of a transatlantic bilateral partnership on third countries and promises have been made to ensure fair access to the world market. Barker and Workman (2013) conducted a comprehensive survey of stakeholders to capture their views on the agreement. The survey ranked issues according to the importance attributed to them, the level of difficulty involved and the likeliness of them being approved, which helps us to understand more clearly the issues covered by agreements such as T-TIP. 


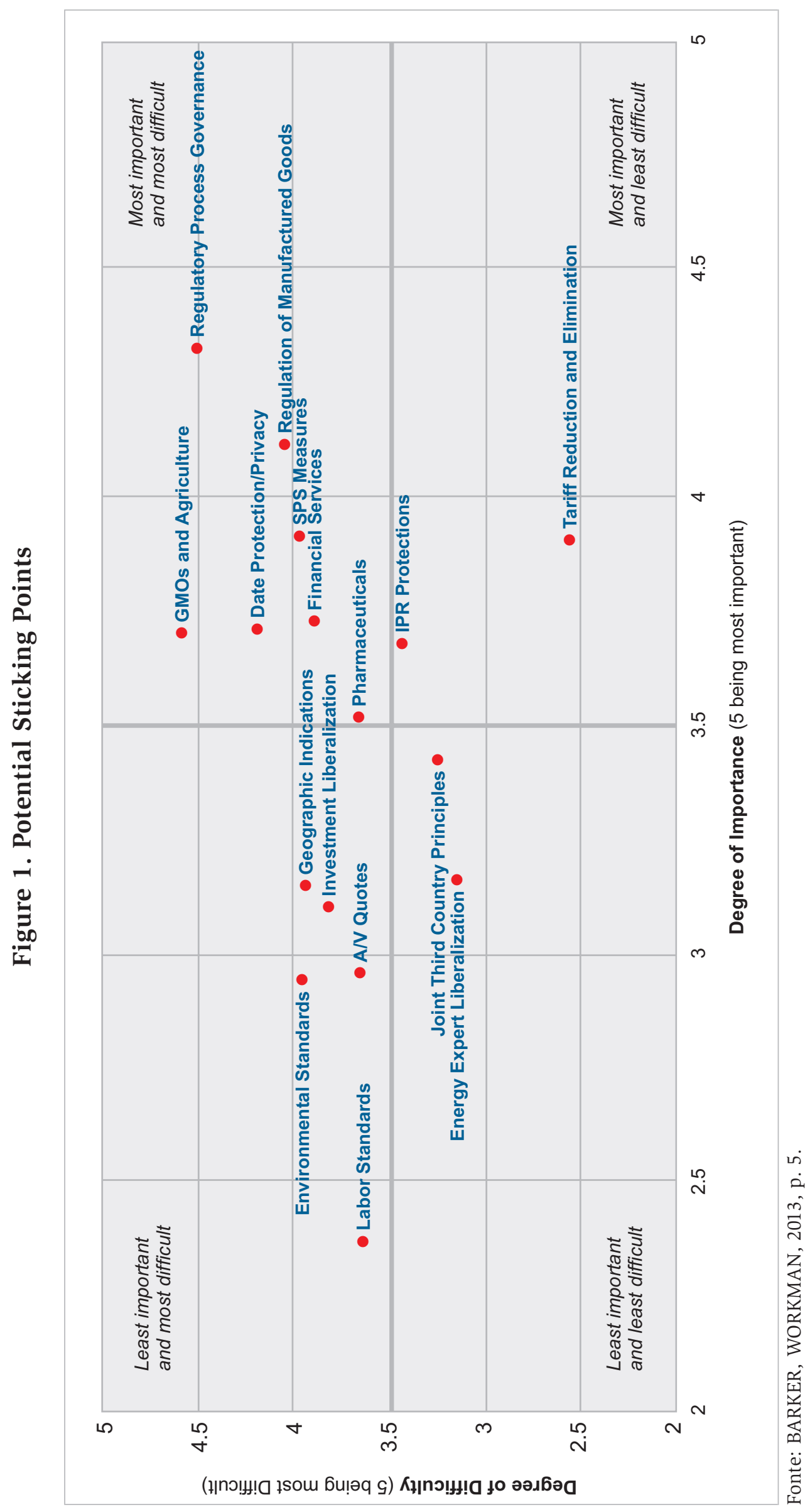


As we can see in figure 1 above, the findings are consistent with public statements by policymakers. The most difficult issues to negotiate are: market access for genetically modified organisms (GMOs) and agricultural products treated with hormones; convergence of regulations across multiple sectors; alignment of regulations on data protection and privacy; and harmonization of regulatory regimes and standards for manufactured goods. The most important issues are among the most difficult as well: GMOs and agriculture, and regulatory convergence. One surprising finding was that stakeholders do not see the convergence in pharmaceutical testing and approval requirements for new drugs and in environmental standards as something difficult to achieve or crucial (BARKER, WORKMAN, 2013, Charts 1 and 2, pp. 3-4).

Once the difficulties are overcome, the EU companies were estimated to be able to sell an additional $€ 187$ billion worth of goods and services a year to the US. This looks good news for jobs. A survey commissioned by Germany's Bertelsmann Foundation revealed however that the US incomes would rise $13.4 \%$ per capita thanks to the T-TIP, whereas those in Europe would only increase 5\%. Even under this disproportionateness of benefits, on balance, Europe has the most to lose if the T-TIP does not go through, since Europe has fewer options than America. Also, there would not be an easy task for the EU to overcome its asymmetries. Europe is experiencing a serious problem of competitiveness of the southern countries such as Greece, and there are differences in the financial rules and exchange rate policies to be reviewed. Also, the institutional procedures to approve a treaty like the T-TIP have to follow all the steps of negotiation, which takes time.

In this scenario, in light of the new US president's vow to stop the T-TIP negotiations, it is important to note two policy options that can effectively boost cooperation, according to the Trade Regulatory Cooperation Report (AHEARN, 2009): (1) attract high-level political support, and (2) increase dramatically the involvement of legislators (the US Congress and the European Parliament). The initiatives to reinforce these two policies have demonstrated their capacity to keep transatlantic cooperation alive.

Thus, the first policy can be associated with the initiative to create the Transatlantic Economic Council (TEC), in April 2007. The Council was designed, in part, to generate the kind of high-level political support that previous initiatives may have lacked. In other words, the institutionalization of the cooperation can bring better conditions to design the terms of the development of the partnership, 
making clear the steps needed to reach the agreement and the limits of the procedures that should be improved.

The second policy (2) is quite important considering the predominance of the executive as a driving force for cooperation. Thus, the involvement of the legislative branch could facilitate the harmonization of the regulatory issues. As well as domestic regulation of standards and measures are necessary in a growing market. Minimal regulation is necessary for the good heath of a free market. Thus, in an increasingly integrated transatlantic marketplace, Congress will be called upon to balance the often-competing demands of trade expansion and barrier reduction against domestic health and safety concerns (AHEARN, 2009).

Finally, supporters of the T-TIP and other new generation treaties such as NAFTA has agreed that these new models of partnership increase the volume of trade and investment with consequences for wages and jobs. Although, the benefits of the new generation treaties are not so evident with regard to real growth and employment. There are concerns in regulatory harmonization and the appropriateness of the ISDS regime in NAFTA (RODRICK, 2015) as well as studies that show benefits flowed to already-wealthy elites, not to workers, their families, and the general poorer population. In the case of NAFTA, "wages stagnated, social protections declined, and violations of worker's organization and collective bargaining rights continued unabated" (COMPA, 2014). Also, despite the good ex ante predictions, NAFTA led to the loss of a million US jobs, and a significant fall in wages (SCOTT CATO, 2015). "In Mexico, the increase in productivity reduced the foreseen increase in manufacturing jobs, and at the same time destroyed a million jobs in the agricultural sector." (BALLERA, 2015, p. 41). In general terms, the urgency of the T-TIP was justified by the need to act in geopolitical strategic way, the interpretation of the "West against the rest" presented as a "defensive" attitude. In reality however it was an "offensive" one, in other "to take advantage of economic, military and political domination so as to impose new regulations on a global scale regardless of multilateral institutions" (BALLERA, 2015, p. 39). As a consequence, companies and business groups from BRICS countries (Brazil, Russia, India, China and South Africa) have started to feel concerned about future preferences of the US and the EU approximation since the Obama administration started to speed the T-TIP. 


\section{If not the T-TIP there still is China and the others}

Neither the United States nor Europe has a monopoly on how to deal with a rising China. Indeed, that may be precisely the point. Both Brussels and Washington have enormous interests in getting the equation right, yet for one reason or another-political mistrust, commercial competition, cultural differences, or others-both have more frequently been at odds over policy toward China than they should be. (GILL, MURPHY, 2008, p. iv).

Gill and Murphy (2008) underlined how much Washington needs to vastly improve its understanding of China-Europe relations on the one hand and broaden transatlantic common ground regarding China's growing influence in the world on the other. China and Europe are important to US, so their steadily relationship has not been sufficiently observed by those against the T-TIP in the US According to the authors, the China-Europe relationship has improved in recent decades, has been institutionalized and has extended to several sectoral dialogues covering areas such as: agriculture, civil aviation, competition policy, customs cooperation, education and culture, information society, intellectual property rights, maritime transport, space cooperation, etc. (GILL, MURPHY, 2008, p. 10-11) Today, as China's influence in the world grows and as the European Union moves to recovery from the serious crisis of the euro, the US policy leaders strengthen its position forward constructing a transatlantic partnership under Obama administration. The T-TIP, then, has been seen as a reaction of the developed world to the accelerated growth of emerging countries, especially China.

Contrarily to what happened in the two past decades, the emerging markets became slow to make progress during the last years. According to the OECD's ${ }^{4}$ chief economist Pier Carlo Padoan, "the bottom line is that advanced economies are growing more and emerging economies are growing less." However, China is, as always, the exception among the BRICS countries (Brazil, Russia, India, China and South Africa).

While during the last Administrations of Presidents Lula and Dilma Rousseff the Brazilian foreign policy has been anchored in participating and playing a leadership role in multilateral forums, especially the BRICS, this emerging economy is involved in one of the most fragile regional integration processes. It has not been part of a bloc following a robust model of economic integration, nor is it participating in

4 The Organization for Economic Cooperation and Development (OECD) produces reports every 2 years on the economic and social development and democracy. 
any of the major transoceanic trade and investment treaties that are giving rise to a new dynamic of strategic cooperation and regionalism. The current scenario is that the US has demonstrated its strength again. There were positive results in unemployment, housing and business investments in US and Europe since 2012. However, we can conclude that the crisis has pushed the proximity of the two political and economic powers. The prospective of the T-TIP was to gains for the EU about 86 billion euros and for the US about 65 billion euro per year. The European business executives say that $80 \%$ of the benefits of an agreement would result from reducing the regulatory burden and bureaucracy, as well as from opening up services and public procurement markets. It is expected that every year an average European household would gain an extra $€ 545$ and the European economy would be boosted by around $0.5 \%$ of GDP, once the deal was fully implemented (TOSTES, 2015). Finally, we have seen a clearer attitude in making this partnership a more popular and visible initiative during the Obama administration, but the issue was avoided during the US presidency campaign. The Transpacific received critics and visibility but the T-TIP was spared by the candidates.

\section{BRICS and Brazil in the context of global powers}

The BRICS countries aimed to form a group of emergent economies that seek reforms in the liberal international order created after World War II. The result is the reordering of international coalitions, the search for new possibilities of pooling of interests and optimization efforts on development and economic growth in the existing liberal order that is sustained by the economic strength that the BRICS were able to show in international flows of trade and capital during the past two decades ago.

Most of countries that integrate the BRICS have large territories, large populations, a varying number of neighbors with whom they need to accommodate interests. Another important feature is that the BRICS countries are natural regional leaders, which can be involved in regional integrations. The discussion about the role of the countries, however, is based on the potential for economic growth and development, but these same countries face the problem of poverty and inequality, anchored in historical processes of social divisions as a legacy of dictatorships and past poverty. Recent past of violence and social conflicts are reflected in the significant difference between indices of human development and inequality when compared with the numbers of developed countries. This means 
that the BRICS countries have a dual ambition: beyond international insertion, they need to solve parallel problems involving domestic policy reforms, social policy adjustments, decreasing violence, poverty and inequality. The decision taken in the fourth BRICS Summit in New Delhi in 2012 and subsequently announced in the fifth BRICS Summit in Durban in 2013 to establish a development bank was achieved in the sixth Summit in Brazil in 2014, which was actually created to be a pivotal player among the BRICS countries. The New Development Bank (NDB) appeared as a promise to increase the weight of BRICS countries in global governance of development finance institutions.

According to the United Nations Development Programme (UNDP) data, China and Brazil have something in common; they made the best performance improvement of the Human Development Index (HDI) among the BRICS countries. According to the UNDP report of 2008, significant economic growth in China drew thousands of people out of poverty, but it remains a challenge to translate this growth equally in all aspects of social welfare and the entire Chinese population. The current China's 0.699 on the HDI represents a remarkable increase of $72 \%$ from the 0.407 it registered on this scale in 1980, or an average year-on-year growth of 1.7 percent. (ENGLISH PEOPLE, 2013)

On trade, despite a very lucrative period for both Brazil and China in the past two decades, the relationship is becoming increasingly asymmetrical. China still intends to reinforce the south-south characteristics of its relationship with Brazil, and the value of better agreements and the strength of the trade between the two countries are shared among them.

Although China became Brazil's main trading partner, Brazil does not figure among China's top ten trading partners (MINISTERIO DAS RELAÇÕES EXTERIORES, 2011). Moreover, relations between the two countries do not constitute a South-South exchange (a balanced exchange between developing countries), as official Brazilian rhetoric may suggest, but an increasingly NorthSouth relationship-with Brazil as an exporter of commodities and an importer of manufactured goods from China. Approximately 79 percent of Brazilian exports to China in the first quarter of 2010 were basic goods (soy, iron ore, and oil). And Brazil's imports from China were mostly electronic and capital goods. In 2000, 49 percent of Brazilian exports to China were basic goods.” (PEREIRA, NEVES, 2011)

Brazil has tried to address the asymmetries of the bilateral exchange with China, however domestic political battles and institutional imperfections are among major source of Brazil's lack of competitiveness. According to a Fitch ratings report 
from 2012: "China's Economic Rise Provides Mixed Benefits for Latin America”, the overall Latin America has benefited from the relationship with China by higher commodity prices, increased growth, increased investment, and improved governmental financials. However, as a result of Latin America's commodity specialization and China's transition into a higher value-added manufacturing exporter, according to the Fitch ratings in 2010, 92\% of Latin American exports to China were commodities. As a consequence, the trade deficit with China has doubled to $0.8 \%$ of regional GDP during 2006 - 2010, from $0.4 \%$ during 2001 2005. Therefore, several experts have argued that the long-term position for Latin American in this partnership would be poor and other sources for growth and trade such as services should be pursued.

\section{Brazil in the context of the feasibility of the T-TIP}

The BRICS countries are clearly grounded in regional political alliances and, at the same time, they actively seek to build stronger multilateral relations. However, unlike its most important trade partners, Brazil is lagging behind in the area of multilateral and bilateral trade agreements: it has no part in the "new generation treaties" on trade and investments. Furthermore, its agenda for preferential agreements is modest (only 22) and its collection of partners is smaller than what one would expect from a country that is seeking to establish itself as an emerging power on the global scene. At the same time, the US and the UE have chosen markedly different strategies for including provisions in their Preferential Trade Agreements (PTAs) that go beyond the World Trade Organization (WTO) agreements (HORN; MAVROIDIS; SAPIR, 2009).

The ambition to join the free trade zones with commitments dealing with issues going beyond the current WTO mandate (e.g. high level of standards regulation and property rights) is far from being the privilege of the wealthier nations though. On 2012, Colombia, Mexico, Chile and Peru signed the Pacific Alliance, which provides zero tariffs for $90 \%$ of goods traded between them. Chile and Peru, including also negotiating with the United States joining the Transpacific Trade Agreement, which includes nine countries on both sides of the ocean and promises to boost trade with Asia. Brazil, however, has tried hard to play a leadership role in the Mercosur since 1990s. ${ }^{5}$

5 Mercosur is composed nowadays by 5 members: Brazil, Argentine, Paraguay, Uruguay, and Venezuela. 
The picture is that Brazilian foreign politics is constrained by the Mercosur and Argentine, which is the buyer of most semi-manufactured Brazilian production but is now under domestic crisis that affect imports from Brazil. As Argentina is the third largest trading partner of Brazil, after China and the United States, every point within Argentinean growth or retraction of its economy means many millions of dollars less in foreign trade. The slowdown of the economy in Argentina made Brazilian exports to the country fall about $20.7 \%$ in 2012 , according to economic consultants of Buenos Aires. The sectors most affected were the auto parts, agricultural machinery and electronics, among others. The fall in imports from Brazil made Argentina's trade deficit with Brazil decrease in 2012 to \$ 1.5 billion - which means a reduction of $73 \%$.

Mercosur has become less of an economic and trade regional project, and more of political forum in recent years. Since the impeachment on Paraguay in 2012 and the entrance of Venezuela as a full member, Mercosur has been accused of becoming a political platform more than a framework for regional development. Anyway, the future of Mercosur can be directly associated to the development both at the multilateral level of the WTO and the interregional preferential level, among others, the T-TIP and TPP. Even considering that the impact of T-TIP on Latin American countries would vary, members of Mercosur, such as Brazil, can suffer with new standards and intellectual property rights. On the other hand, the success of the two big transoceanic Treaties would impact other multilateral mechanisms for regulating trade. The global multilateral trade system is to be impacted in a dimension we still cannot foresee.

Since Brazil was classified as a country of citizens with medium to high income levels, meaning that Brazil lost some of its current perks in trade relations with the European Union, the acceleration of Mercosur-EU negotiation become a matter of surviving. The Generalized System of Preferences (GSP) allowed the reduction of import tariffs on a number of items sold by developing nations the recent loss still needs to be calculated and new strategies need to be found urgently. In 2012 Brazil was the third biggest beneficiary, with sales of $\$ 2.3$ billion, behind India (US $\$ 4.5$ billion) and Thailand ( $\$ 3.7$ billion). In all, the US gives the advantage to 127 countries and territories under the GSP. Approximately 3,500 products used by the auto parts, construction, chemical, steel, capital goods and food again are taxed.

Besides, Brazilian exports of steel, machinery, fuel, beef and cotton go through the competition to sell to Europe, since the US sell the same products. For airplanes and cars, products manufactured here in Brazil have much competition in the 
US, European products, as in the EU, US products. Brazil's trade deficit raises urgency for new agreements. Indeed, there are two potential scenarios for Brazil: find new breathes with Mercosur or look for a way out the Mercosur. There is no way in between. At the same time that Chile and Peru are making agreements including free trade and bilateral agreements with the US, EU and China, Brazil shy it keeps waiting for Mercosur.

In the 1990s, the European market was the destination of about $30 \%$ of the Brazilian exports. Since then, there were fifteen years of conversation first launched in 1999. Both sides have missed deadlines and compromises. Nowadays, the EU is still a major market for Brazilian commodities, especially agricultural goods. However, the exports dropped to about $20 \%$. If the T-TIP gained breath, there is a risk that the US come to gain preference as an exporter of agricultural commodities for the European market, which directly affects Brazil.

\section{Conclusions}

The interdependent context associated to the complex relation known as the "trade-investment-service nexus" (BALDWIN, 2011), which arose from the new GVCs, reinforces the need for cooperation and the search for greater policy coordination between countries (KEOHANE, NYE JR, 1989). Thus, there is no disconnect between the way business operates beyond borders today and the US and the EU's methods of pursuing international trade. Comprehensive joint efforts to deregulate international trade is obviously a demand of big corporations and economic groups that operate around the world and do business with governments. The US and EU currently control about half of the supply of services in the world and account for one third of the global flow of goods. Although the two economic powers are still recovering from the crisis, defenders of the T-TIP argue that it can help boost cooperation between the regions, as it could result in companies saving millions of euros. If the two powers were to continue moving ahead with the transoceanic agreements, it would lead to a new global trade order with a balance of power that is completely different from the one described in predictions on the rise of the East. Although Obama and Merkel have said that the T-TIP could benefit their countries and regions, their affirmations seem to go against Ruggie's (1992) view on multilateralism. According to Ruggie, multilateralism is a demanding organizational form that requires its participants to renounce temporary advantages 
and the temptation to define their positions in terms of national interests. Also, multilateralism requires global actors to avoid ad hoc coalitions and adopting policies based on situational exigencies and narrow interests. "Yet [as] it is by no means a rare organization form in the world" (CAPORASO, 1992, p. 604), it is worth understanding the global consequences of comprehensive partnerships established between the leading economic powers of the international order.

It is crucial to highlight that transatlantic relations are already strong, even without the T-TIP. At the end of 2014, bilateral investments between Germany and the US totaled $\$ 339$ billion and created high-paying jobs in both countries. Since 2015, the US has become Germany's most important trading partner with a trade volume of 173 billion euros, and conversely, Germany has become a cornerstone of the US's economic relations with the EU. Indeed, the significance of transatlantic trade is even more impressive when we look at trade between the US and the EU as a whole: the trading volume in 2015 amounted to 620 billion euros, the largest between any two partners in the world.

Resistance to the treaty exists on both sides of the Atlantic. Yet, one cannot deny that the arguments of the European opponents are more sound. Critics claim that the treaty will benefit big traders and exporters of products produced on the large scale in particular. Furthermore, some issues are more sensitive for European activist groups than for the ones based in the US - namely, the environment and health, which involve different elements of concern and protections for the productive and trade sectors on both sides of the Atlantic. For T-TIP opponents in Europe, the regulatory measures expected to be adopted in the areas of food security, health, animal welfare, and the environment will bring more changes for European procedures and principles than it will for those in the US. Even before the recent leaks ${ }^{6}$ and the increase in protests and the rejection of the T-TIP emerged, shortly after negotiations were launched in July 2013, the Minister of State for Foreign Trade, the Promotion of Tourism and French Nationals Abroad, Matthias Fekl, warned the French Senate about the treaty's incompatibility with the fundamental principles of French policy. Examples are France's protection measures in the area of culture (especially the film industry) and agriculture, as well as its legal autonomy to resolve disputes in the future.

In 2016, after the EU Council of Ministers approved the T-TIP, Donald Trump was elected as the $45^{\text {th }}$ President of the United States. He committed to putting

6 In 2015, texts on the content of and positions on the T-TIP were leaked. The documents were obtained by Greenpeace and exposed by The Guardian. 
an end to the US's participation in the "big treaties" such as NAFTA, the TPP and the T-TIP. Trump may still surprise his electors, as he has made more promises than he can keep. In this context, this article hopes to have contributed to the analysis of possible or inevitable scenarios for a new form of governance being developed over the last ten years. Despite the current uncertainty about the future of trade treaties, it is fundamental to identify the pros and cons of such agreements, the impacts of their failure or success, and Brazil's role in decisions in which the country has acted mainly as a spectator.

\section{References}

AHEARN, Raymond J. Transatlantic Regulatory Cooperation: Background and Analysis CRS Report RL34735, August, 2009. Available at: < http://www.fas.org/sgp/crs/ row/RL34717.pdf > . Accessed at: 10 sep. 2016.

ALESINA, Alberto; LA FERRARA, Eliana. Ethnic Diversity and Economic Performance. Journal of Economic Literature. vol. 43, n. 3, 2005, pp.762- 800.

AXELROD, Robert. The Evolution of Cooperation. New York: Basic Books, 1983.

BALDWIN, Richard. 21 ${ }^{\text {st }}$ Century Regionalism: Filling the gap between $21^{\text {st }}$ century trade and $20^{\text {th }}$ century trade rules. World Trade Organization: Economic Research and Statistic Division, Staff Working Paper ERSD-2011-08, 2011. Available at: < https:// www.wto.org/englisH/res_e/reser_e/ersd201108_e.pdf > . Accessed at: 17 oct, 2016.

BALDWIN, Richard. The WTO tipping point, VoxEU.org, 1/7/2008 > . Available at: < http://www.voxeu.org/index.php?q = node/1345 > . Accessed at: 17 oct. 2016.

BALLERA, Ricard. The TTIP or Europe. In: KHORANA, Sangeeta (ed.) The Transatlantic Trade and Investment Partnership (TTIP) negotiations between the EU and the USA. Caught between myth and reality? Barcelona: CIDOB, 2015, chap 3 pp. 37-47.

BARKER, Tyson, WORKMAN, Garrett. The Atlantic Trade and Investment Partnership: Ambitious but Achievable. A stakeholder Survey and Three Scenarios. Washington DC, Atlantic Council/Bertelsmann Foundation. 2013.

COMPA, Lance. Labor Rights and Labor Standards in Transatlantic Trade and Investment Negotiations: An American Perspective. In: SCHERRER, Christoph (Ed.) The Transatlantic Trade and Investment Partnership (TTIP): Implications for labor. Munchen: Rainer Hampp Verlag, p. 120-136. Available at: < https://www.uni-kassel. de/einrichtungen/fileadmin/datas/einrichtungen/icdd/Publications/Volume5.pdf > . Accessed at: 10 sep. 2016.

COOPER, William. Trade Promotion Authority (TPA) and the Role of Congress in Trade Policy. CRS Report for Congress, vol. 13, January, 2014, Available at: < http://fas.org/ sgp/crs/misc/RL33743.pdf > . Accessed at: 1 aug. 2016. 
CAPORASO, James. International relations theory and multilateralism: the search for foundations. International Organization. vol. 46, n. 3 Summer 1992.

ENGLISH PEOPLE. China climbs on human development index. 16 mar. 2013. Disponível em: < http://english.peopledaily.com.cn/90883/8170028.html > . Acceded at: 10 mar. 2017.

FITCH RATINGS. China's Economic Rise Provides Mixed Benefits for Latin America. 2012. Disponível em: http://www.fitchratings.com/creditdesk/reports/report_frame. cfm?rpt_id $=677239>$. Acceded at: 10 mar. 2017.

FITCH RATINGS. Website. Disponível em: http://www.fitchratings.com/web/en/dynamic/ fitch-home.jsp > . Acceded at: 1 fev. 2017.

FAWCETT, Louise; HURRELL, Andrew (Orgs.). Regionalism in World Politics - Regional Organization and International Order. Oxford: Oxford University Press, 1995.

Fitch: China's Economic Rise Provides Mixed Benefits for Latin America, May, 9, 2012. Available at: < http://newamericamedia.org/2011/01/latin-america-divided-overties-with-china-growing-suspicions-over-chinese-presence-in-latin-america.php $>$. Accessed at: 10 sep. 2016.

FINAL REPORT HIGH LEVEL WORKING GROUP ON JOBS AND GROWTH

February, 2013. Available at: < http://trade.ec.europa.eu/doclib/docs/2013/february/ tradoc_150519.pdf > . Accessed at: 10 sep. 2016.

FRANCK, D. S.. The legitimacy crisis in investment treaty arbitration: privatizing public international law through inconsistent decisions. Fordham Law Review. 2005, pp. 1521-1625.

GILL, Bates; MURPHY, Melissa. China-Europe Relations. Implications and Policy Responses for the United States. Center for Strategic \& International Studies - CSIS. Washington DC, The CSIS Press, 2008.

ORGANISATION FOR ECONOMIC CO-OPERATION AND DEVELOPMENT (OECD). Global Value Chains. Disponível em: < http://www.oecd.org/sti/ind/global-value-chains.htm > . Acceded at: 1 fev. 2017.

HORN, Henrik; MAVROIDIS, Petros C.; SAPIR, André. Beyond the WTO? An Anatomy of EU and US preferential trade agreements. Brussels: Bruegel Blueprint Series vol. VII. 2009. Available at: < http://bruegel.org/wp-content/uploads/imported/publications/ bp_trade_jan09.pdf > . Accessed at: 21 nov. 2016.

KEOHANE, Robert. After Hegemony: Cooperation and Discord in the World Political Economy. 2. ed. Princeton: Princeton University Press, 2005.

KEOHANE, Robert O; NYE JR, Joseph. Power and interdependence: World Politics in Transition. New York: Harper Collins Publishers, 1989.

KEOHANE, Robert O.; NYE JR, Joseph. Power and Governance in a partially globalized world. London: Routledge, 2002.

KHORANA, Sangeeta (ed.) The Transatlantic Trade and Investment Partnership (TTIP) negotiations between the EU and the USA. Caught between myth and reality? Barcelona: CIDOB, 2015. 
MERKEL, Angela; OBAMA, Barack. The Future of Transatlantic Relations. WirtschaftsWoche. 2016. Available at: < http://www.wiwo.de/politik/ausland/us-wahlen/usa-and-germanythe-future-of-transatlantic-relations/14853710.html > . Accessed at: 21 nov. 2016.

MINISTÉRIO DAS RELAÇÕES EXTERIORES. Brasil e China no Reordenamento das Relações Internacionais: Desafios e Oportunidades. Brasília: Fundação Alexandre Gusmão, 2011. PEREIRA, C.; NEVES, J. Brazil and China: South-South Partnership or North-South Competition? Policy Paper. Foreign Policy at Brookings, n. 26, March, 2011. Available at: < https://www.brookings.edu/wp-content/uploads/2016/06/03_brazil_china_ pereira.pdf > . Accessed at: 1 dez. 2016 .

RAZA, Werner; GRUMILLER, Jan; TAYLOR, Lance; TRÖSTER; ARNIM, Rudi von. An Economic Assessment of the Claimed Benefits of the Transatlantic Trade and Investment Partnership (TTIP). In: SCHERRER, Christoph (Ed.) The Transatlantic Trade and Investment Partnership (TTIP): Implications for labor. Munchen: Rainer Hampp Verlag, 2014. pp. 41-99 Available at: < https://www.uni-kassel.de/einrichtungen/fileadmin/ datas/einrichtungen/icdd/Publications/Volume5.pdf > . Acceded at: 10 sep. 2016.

REUTERS. Website. Disponível em: http://www.reuters.com/article/2012/05/09/ idUS194499 + 09-May-2012 + BW20120509 > . Acceded at: 1 fev. 2017.

RODRIK, D. The War of Trade Models. Dani Rodrik's webblog. Unconventional thoughts on economic development and globalization. 4 May 2015 Available at: < http://rodrik. typepad.com/dani_rodriks_weblog/2015/05/the-war-of-trade-models.html. > Acceded at: 10 sep. 2016.

TOSTES, Ana Paula. The effect of the TTIP on the BRICS countries: the case of Brazil. In: ROY, Joaquín (Ed.) The New Atlantic Community: The European Union, The US and Latin America. Miami-Florida: European Union Center/Jean Monnet Chair, 2015.

RUGGIE, John Gerard. Multilateralism: The Anatomy of an Institution. International Organization. vol. 46, n. 3, july 1992.

SCOTT CATO, Molly. I've seen the secrets of TTIP, and it is built for corporations not citizens. The Guardian. 2 feb. 2015. Available at: < http:www.theguardian.com/commentis free/2015/feb/04/secrets-ttip-corporations-not-citizens-transatlantic-trade-deal > . Acceded at: 10 sep. 2016.

STUDY ON “EU-US HIGH LEVEL WORKING GROUP FINAL REPORT.” (Ministry of Economic Affairs, Agriculture and Innovation). Ecorys, Rotterdam, October 2012. Available at: < http://www.ecorys.nl/contents/uploads/factsheets/350_1.pdf > . Accessed at: 1 aug. 2016.

THE OBAMA WHITE HOUSE (official website), 2013 Available at: http://www.youtube. com/watch?v = A7w7OvujpkU > . Accessed at: 30 mar. 2016.

TRANSATLANTIC TRADE \& INVESTMENT PARTNERSHIP ADVISORY GROUP. Meeting Report. December 2014, Available at: < http://trade.ec.europa.eu/doclib/docs/2014/ december/tradoc_152937.pdf >. Accessed at: 10 sep. 2016.

UNDP Report 2008. Available at: < http://hdr.undp.org/sites/default/files/reports/268/ hdr_20072008_en_complete.pdf >. Acessed at: 1 dez. 2016. 


\title{
International Cooperation, Overseas Development, Foreign Assistance: brief historical and bibliographic review on Foreign Aid
}

\author{
Cooperação Internacional, Desenvolvimento \\ Ultramar, Assistência Estrangeira: breve revisão \\ histórica e bibliográfica sobre a ajuda externa oficial ${ }^{1}$
}

DOI: $10.21530 /$ ci.v12n1.2017.584

Ana Maura Tomesani ${ }^{2}$

\section{Resumo}

Este artigo se presta a introduzir o leitor ao conceito, histórico, principais instituições e debates contemporâneos sobre o fenômeno da ajuda externa oficial (foreign aid, em inglês) - que alguns preferem tratar de cooperação internacional para o desenvolvimento, ainda que tais termos não sejam exatamente sinônimos, como se verá. A literatura trabalhada sugere que o debate contemporâneo em torno da ajuda externa oficial possa ser reduzido a duas frentes: a frente dos que buscam as motivações para doar e a frente dos que medem o impacto das doações. Chamamos a atenção, ao final deste trabalho, para o fato de que a maior parte da literatura disponível foi escrita por pesquisadores de países que fazem parte da comunidade de doadores, e é esta a literatura que embasa e orienta as ações das agências de cooperação. Há pouco material que analise a ajuda externa sob a ótica dos países receptores e parte do existente é bastante crítica a tal forma de ajuda. Sugere-se a necessidade de desenvolver mais esses tipos de trabalho.

Palavras-chave: Ajuda externa, foreign aid, cooperação internacional para o desenvolvimento, cooperação bilateral, organismos multilaterais.

\footnotetext{
Abstract

This article aims to introduce the reader to the concept, history, main institutions and contemporary debates around the phenomenon of foreign aid - which some prefer to treat as international cooperation for development, although, as we will see, these terms are not

1 O título deste artigo faz alusão a outros termos comumente utilizados para designar a ajuda externa oficial

2 Doutoranda em Relações Internacionais no IRI/USP. E-mail: anamaura@gmail.com ou anamaura@usp.br Artigo submetido em 17/11/2016 e aprovado em 16/03/2017.
} 
exactly synonymous. The literature suggests that the contemporary debate about official foreign aid can be reduced to two fronts: the front of those who seek the motivations for donating and the front of those who measure the impact of donations. In this text, we also draw attention to the fact that the majority of literature that is accessible is not only in English, but has been written by researchers from countries belonging to the community of donors. Furthermore, that it is this literature which underlies and guides the action of cooperative agencies. There is little material that analyses external aid from the perspective of the receiving countries, and the few existing works are generally very critical concerning this type of aid. We suggest the need to develop such research.

Keywords: foreign aid, international cooperation for development, bilateral cooperation, international assistance, multilateral organizations.

\section{Introdução}

A cooperação internacional para o desenvolvimento é tão difundida hoje em dia que parece difícil imaginar que se trata de uma novidade de pouco mais de 70 anos. E, ao longo desse tempo, tem estado no centro de debates as seguintes questões: porquê, como e para quem doar. O próprio termo "cooperação internacional para o desenvolvimento" não é exatamente um consenso ${ }^{3}$. Vários autores que trabalham o tema - lembrando que boa parte da literatura está em língua inglesa - preferem o termo foreign aid, ou “ajuda externa”, em português.

Uma razão para isso seria o fato de que, quando as agências oficiais de cooperação internacional para o desenvolvimento começaram a surgir nos países do hemisfério norte, nas décadas de 1950 e 1960, apenas o que estava no âmbito dessas agências era chamado de cooperação internacional para o desenvolvimento (doravante, CID) e avaliado enquanto tal. Mas o montante de recursos que um país doa a outro pode não passar por essas agências. Ainda assim, é ajuda externa, mesmo não sendo avaliado pelos órgãos competentes enquanto CID. Em outras palavras, todo o CID é ajuda externa, mas nem toda ajuda externa é “carimbada” como CID pelos países doadores. Um exemplo é o gasto para fins militares, que não está enquadrado na definição de Ajuda Oficial para o Desenvolvimento ( $\left.\mathrm{AOD}^{4}\right)$.

3 Vale esclarecer que o temo "cooperação internacional” é bem mais amplo do que a "cooperação internacional para o desenvolvimento” e pode ser utilizado para designar variados acordos assinados entre países específicos ou no âmbito de organizações multilaterais.

4 Em inglês, ODA - Official Development Assistance. O termo foi criado pela OCDE (Organização para a Cooperação e Desenvolvimento Econômico) para designar os fluxos de recursos transferidos dos países desenvolvidos para os em desenvolvimento. 
Apenas para ilustrar, Bayley (2006), ao tratar do financiamento norte-americano de programas relacionados à segurança pública no exterior, explica que programas de policiamento deixaram de ser financiados pela USAID na década de 1970 porque foram caracterizados como programas relacionados à defesa e segurança, mas seguiram sendo financiados pelos EUA através de outras agências governamentais.

Outra razão que faz com que alguns autores prefiram o termo "ajuda externa" é o fato de que o termo "cooperação internacional para o desenvolvimento", como trabalhado pela Organização para a Cooperação e Desenvolvimento Econômico - OCDE, implica necessariamente os fluxos de recursos transferidos dos países desenvolvidos para aqueles em desenvolvimento, o que caracterizaria a cooperação Norte-Sul apenas, e desconsideraria a cooperação Sul-Sul ou mesmo a transferência de recursos entre países do Norte - Lancaster (2008, pag. 9-10) explica que a definição de AOD exclui transferências de fundos públicos que ocorrem entre países como Rússia, Ucrânia, Israel e Coreia. Além isso, ela explica que a finalidade da ajuda externa, em sua visão, é a melhoria da condição humana (human betterment) e não o desenvolvimento, por entender que o termo "desenvolvimento" é muito amplo e genérico. Há ainda quem entenda que o termo "cooperação" implica benefícios mútuos e intercâmbio horizontal (seja de bens, recursos ou conhecimento), o que significa dizer que o termo só se aplicaria bem à cooperação Sul-Sul, sendo que à tradicional cooperação Norte-Sul o termo ideal seria "assistência" (SOUZA, 2014).

Por conta dessa imprecisão conceitual, é importante esclarecer que estamos tratando aqui da transferência de fundos públicos de um país para outro (dentro de um acordo bilateral) ${ }^{5}$ ou para uma organização internacional (num acordo de um país para com uma organização intermediária de assistência multilateral) ${ }^{6}$ com o objetivo de melhorar a condição social e econômica de um outro país ou grupo de países. Essa é uma definição abrangente de ajuda externa oficial, adaptada de Lancaster (2008) e Riddell (1987), dois grandes estudiosos do tema, que balizou nossa revisão bibliográfica. Ela contempla os programas de CID e

5 Como, por exemplo, o financiamento japonês, via JICA (Japan International Cooperation Agency), de programas de polícia comunitária em São Paulo entre as décadas de 1990 e 2000 (LOCHE, 2010).

6 Como, por exemplo, a contribuição financeira a um escritório ligado à Organização das Nações Unidas - ONU (como UNESCO, UNICEF e PNUD) para financiamento de programas em diversos países. A OCDE considera também como “cooperação internacional para o desenvolvimento" empréstimos realizados por bancos de desenvolvimento (como Banco Mundial e BID), nos quais ao menos $25 \%$ do valor total transferido é considerado crédito não reembolsável ou grant (doação). 
outros programas de transferência de fundos públicos para países estrangeiros que não estejam oficialmente caracterizados enquanto CID. É com tal definição que trabalhamos ao longo do texto.

Vale destacar que há autores que categorizam recursos provenientes de fundações privadas como cooperação internacional. Reconhece-se a importância dessas instituições na formação de comunidades científicas em diversos países em desenvolvimento. Contudo, tais doações são provenientes de fundos privados e não precisam, portanto, estar subordinadas às diretrizes de política externa dos seus países de origem. Mais adequada parece ser a categorização desse financiamento como "filantropia científica", como propõe Marinho (2001), do que cooperação científica internacional, termo utilizado por Faria e Costa (2006) ao tratarem das diferenças de atuação das Fundações Rockefeller e Ford no fomento às comunidades científicas de países em desenvolvimento. Assim, os tópicos que se seguem acerca do tema não contemplam as fundações privadas multinacionais, mas apenas a ajuda externa oficial, aquela em que os doadores constituem nações, com ou sem a intermediação de uma organização internacional.

A seção seguinte apresenta um histórico da ajuda externa oficial, passando rapidamente pelas experiências anteriores à Segunda Guerra, pelas instituições de Bretton Woods, pelo Plano Marshall, pela OCDE e pela criação das agências de cooperação para o desenvolvimento. Esse histórico está baseado na literatura sobre o tema e nos documentos oficiais das instituições envolvidas. A terceira seção trata da ajuda externa oficial no contexto pós-Guerra Fria e dos debates que surgiram nesse período - que, no entender dessa autora, parecem ter se desdobrado em duas frentes: a frente dos que buscam as motivações para doar e a frente dos que medem o impacto das doações. Indico ainda que esse é um campo em que não convém buscar conclusões generalizantes, dada a enorme diversidade dos países doadores e receptores, tanto em termos geográficos como sociais, econômicos e culturais. A seguir, as duas frentes são trabalhadas em subseções, expondo alguns trabalhos que podem ser classificados em cada uma delas.

Nas considerações finais, reforço o interesse deste trabalho, que se presta a introduzir leitores ao tema, lembrando que se trata de uma revisão que procura trabalhar o histórico e os debates atuais sobre ajuda externa oficial sem nenhuma pretensão de esgotá-los. Ressalto que boa parte da literatura sobre o 
tema é produzida por países que fazem parte da comunidade de doadores e que tal literatura embasa e orienta as ações das agências de cooperação. Há pouco material que analise a ajuda externa sob a ótica dos países receptores e sugere-se a necessidade de desenvolver tais trabalhos? ${ }^{7}$

\section{Histórico}

Os primórdios daquilo que se pode chamar de ajuda externa oficial datam do fim da Segunda Guerra Mundial. Antes disso, há registros de transferência de recursos para a ajuda humanitária (principalmente no período após a Primeira Guerra Mundial) e assistência prestada por potências europeias para suas colônias. No entanto, essa transferência de recursos não era institucionalizada e muito menos permanente, já que a “caridade” não era entendida como uma utilização adequada dos fundos públicos, e menos ainda quando os recursos eram dirigidos a pessoas que estavam para além das próprias fronteiras. Era sempre considerada como temporária e tinha por objetivo a recuperação da condição anterior da população beneficiada, ou seja, o restabelecimento da ordem original, ainda que tal ordem fosse também precária (LANCASTER, 2008).

O cenário pós-Primeira Guerra e a ausência de acordos comuns de cooperação financeira no período entreguerras deixou vários Estados em uma situação de penúria que levou muito tempo para ser revertida e afetou mesmo as economias dos países menos devastados com a guerra. Por conta disso, durante e após a Segunda Guerra, foram selados alguns acordos entre os países aliados visando ao alívio emergencial e, posteriormente, à reconstrução dos mais afetados (LANCASTER, 2008; MOYO, 2009). Boa parte dos atuais organismos internacionais de cooperação financeira foram criados nesse ambiente. O BIRD (Banco Internacional para a Reconstrução e Desenvolvimento) - hoje Banco Mundial - e o Fundo Monetário Internacional foram criados em 1944, durante reunião em Bretton Woods, New Hampshire, tendo como objetivo a reconstrução dos países devastados pela Segunda Guerra (BANCO MUNDIAL, 2016) e a recuperação de suas economias. Em 1947, é criada a Organização para a Cooperação Econômica Europeia (OEEC, em inglês) que deveria administrar e distribuir os fundos do Plano Marshall, que

7 Ayllón (2006) explica que a CID constitui um campo consolidado de estudos nos EUA e Europa e que surpreende o fato do tema despertar pouco interesse na comunidade brasileira de internacionalistas. 
consistia numa injeção de capital americano nos países cuja economia havia sido devastada pela guerra. O sucesso da OEEC na administração dos recursos do Plano Marshall acabou atraindo os EUA e o Canadá para a organização que, então com 14 membros, tornou-se a OCDE (Organização para a Cooperação e Desenvolvimento Econômico) ${ }^{8}$ em 1960.

O caráter da ajuda externa mudou significativamente ao longo desse período, quer em termos de quantidade como em termos da natureza da doação. O Plano Marshall, inicialmente criado como um plano para a recuperação e restabelecimento de países devastados após a Segunda Guerra, pode ser entendido, também, como um plano anticomunismo, já que a injeção de recursos evitava a absorção desses países pelo bloco soviético, uma vez que a União Soviética também estava promovendo programas de ajuda externa aos países em recuperação na Europa Oriental.

Assim que razoavelmente recuperados, entre final dos anos de 1950 e início dos de 1960, os países ocidentais financiados pelo Plano Marshall começaram a ser pressionados pelos Estados Unidos para desenvolverem seus próprios programas de ajuda externa, visando à contenção do avanço comunista nos países pobres e/ou pouco industrializados (LANCASTER, 2008). É nesse contexto que se cria também, em 1959, o Banco Interamericano de Desenvolvimento (BID), durante reunião da Organização de Estados Americanos (OEA). Com um propósito um pouco diferente daquele do Banco Mundial - marcado fortemente pela ideia de reconstrução e de ajuda emergencial -, o BID surge como uma plataforma de ajuda mútua entre os países americanos visando o desenvolvimento em vários setores (BID, 2016). Outros bancos regionais de desenvolvimento surgiram nos anos subsequentes, como o Banco Africano de Desenvolvimento (1964) e o Banco Asiático de Desenvolvimento (1966) (GPEARI, 2016).

Até o início dos anos de 1960, a maioria dos países da Europa Ocidental, mais o Japão, tinham todos criado programas de ajuda externa - e alguns deles estabeleceram agências permanentes de ajuda externa em alguns casos - para prestar assistência a países estrangeiros. Países que possuíam colônias no Sul (como Reino Unido e França) já contavam com órgãos estatais para envio de recursos ao exterior e apenas ampliaram suas estruturas para contemplar essa

8 A instituição conta hoje com 35 membros. O Brasil é considerado "parceiro estratégico", bem como a Índia, a China, a África do Sul e a Indonésia. Fonte: arquivos virtuais da OCDE. Disponível em: < http://www.oecd. org/about/membersandpartners/ > . Acesso em: mar. 2017. 
nova demanda. A Agência Francesa de Desenvolvimento (AFD) existia desde 1941 como "um vasto dispositivo de cooperação entre a metrópole e seus territórios ultramarinos" (AFD, 2016). O Departamento para o Desenvolvimento Internacional do Reino Unido (DIFD, em inglês), apesar de oficialmente criado em 1964, foi desenvolvido dentro da estrutura do então Ministério de Desenvolvimento Ultramar, que substituiu o antigo Colonial Development Advisory Committee, em atividade desde 1929 (BARDER, 2005).

De toda forma, a maior parte das agências nacionais para ajuda externa oficial, que nesse período passaram a adotar termos como "cooperação internacional", "desenvolvimento internacional" ou "assistência internacional” em suas siglas, surgiu na década de 1960 - a exemplo da USAID, United States Agency for International Development (1961), do DED, German Development Service (1963) e da CIDA, Canadian International Development Agency (1968). Vale esclarecer que alguns países, apesar de já terem programas bem consolidados de ajuda externa oficial nesse período, demoraram um pouco mais para constituir suas próprias agências. O Japão, por exemplo, já possuía programas de cooperação técnica ultramarina desde 1954, mas a JICA, Japan International Cooperation Agency, só foi estabelecida em 1974 (JICA, 2016).

Todas essas agências passaram a se reunir regularmente no Development Assistance Committee (DAC), um comitê de aid donors (doadores) criado dentro da estrutura da OCDE em 1960. Funcionava inicialmente como um fórum de consulta entre os países doadores e sua institucionalização, em 1961, tinha como objetivo a criação de um espaço para o monitoramento dos fluxos de recursos provenientes da ajuda externa oficial dos países membros. O argumento do grupo formado inicialmente era de que, para que a ajuda externa aos países em desenvolvimento se tornasse permanente e efetiva, ela precisava ser coordenada entre doadores para não haver sobreposição de recursos ou falta deles em setores estratégicos ou países específicos. Era necessária a produção de dados consistentes sobre recursos transferidos, setores, países receptores e parcerias envolvidas. Já em 1962, o DAC lançava as primeiras publicações compilando dados relativos à AOD e tem início a produção sistemática de estatísticas sobre a cooperação para o desenvolvimento (OCDE, 2016). Desde então, as decisões tomadas no âmbito do DAC passaram a ser orientadas pelos dados gerados pelo setor de estatísticas do comitê. As resoluções do DAC determinam o direcionamento e volume dos recursos alocados para a "cooperação para o desenvolvimento" no mundo, apontando 
tendências setoriais e regionais importantes de serem observadas por estudiosos do assunto 9 .

O PNUD (Programa das Nações Unidas para o Desenvolvimento) também surgiu nesse período (1965), a partir de uma fusão do Expanded Programme of Technical Assistance ou EPTA (criado em 1949 e formado por 6 agências das Nações Unidas) e do United Nations Special Fund (1958). O PNUD gerencia recursos provenientes de contribuições voluntárias de signatários das Nações Unidas para executar programas em países em desenvolvimento. É possível que o papel dos Estados Unidos como maior país doador da Organização das Nações Unidas possa ter influenciado os programas do PNUD no sentido de configurá-los como escudos anticomunistas nos países capitalistas periféricos, muito embora a União Soviética também fosse signatária da ONU. A corrida armamentista que caracterizou tal período se refletiu numa corrida para a prestação de assistência financeira, opondo países ocidentais e orientais, e é difícil que o PNUD tenha se mantido neutro nessa disputa. Em todo caso, trata-se de uma hipótese a ser testada, que carece de investigações científicas para tanto.

As décadas de 1960 e 1970 são fortemente marcadas também pelo surgimento de diversas ONGs de caráter humanitário que engrossaram o corpo de igrejas e organizações de caridade envolvidas na redução de sofrimento humano e promoção do alívio em países devastados por catástrofes naturais, fome ou guerras civis. Essas organizações começaram a defender o aumento da ajuda dos países desenvolvidos para os países pobres (VALENTIN, 2005; LANCASTER, 2008). No final da década de 1950, o Conselho Mundial de Igrejas recomendou que os governos desenvolvidos devessem dedicar pelo menos $1 \%$ do seu PIB para ajudar os países pobres (LANCASTER, 2008). Durante os anos de 1960, os membros do DAC aceitaram esses termos, mas os recuaram alguns anos depois com a justificativa de que eles não podiam controlar os fluxos privados. Assim, eles fixaram uma meta menos otimista para o envio de fluxos oficiais: $0,7 \%$ do PIB de cada país-membro deveria ser dedicado à assistência externa (OCDE, 2017).

9 É preciso esclarecer que o Creditor Reporting System (CRS), a central de dados sobre ajuda externa compilados pelo DAC e que constitui a fonte oficial de estatística sobre assistência para o desenvolvimento para todos os países que fazem parte do DAC, trabalha apenas com os países-membros da OCDE e do DAC. Essa central não abrange o volume doado, por exemplo, por países do Sul Global, países do Oriente Médio/Ásia (com exceção do Japão e da Coreia, que fazem parte da OCDE) ou de alguns países da Europa do Leste. Isso significa não apenas que temos um apagão estatístico com relação aos dados de doações feitas pelo Bloco Soviético durante toda a Guerra Fria, como ainda que os dados compilados pela OCDE não dão conta do recente fenômeno do aumento de doações provenientes de países autoritários não ocidentais, como China e Irã (WRIGHT; WINTERS, 2010). 
Nesse período, começa a ganhar força também o Non-Aligned Movement (NAM), ou o Movimento dos Não-Alinhados. Tratava-se de um grupo de países, boa parte dos quais formados por ex-colônias, definidos como "do Sul" - em contraposição aos países desenvolvidos do Norte - que passaram a formar blocos para discutir seus destinos políticos e econômicos autonomamente, bem como para estabelecer acordos de cooperação técnica, sem a interferência de suas antigas metrópoles, a exemplo da Organização da Unidade Africana e do G-77 (MODI, 2011). O ativismo do NAM foi grande na década de 1970 e culminou com o Plano de Ação para a Cooperação Sul-Sul da Conferência das Nações Unidas para o Comércio e o Desenvolvimento - UNCTAD, em inglês - elaborado em Buenos Aires, no ano de 1978 (MODI, 2011; BURGES, 2012).

O desenvolvimento a longo prazo foi incluído na agenda das agências de ajuda internacional na década de 1970 e não foi por acaso. Naquele momento, a maioria dos países do mundo já era doadora ou beneficiária de ajuda externa, que tinha então se tornado um elemento comum e quase "naturalizado" nas relações internacionais, principalmente entre países ricos e pobres. Além disso, a profissionalização das agências de assistência internacional estava em curso e o planejamento estratégico como ferramenta de intervenção da ajuda foi introduzido e difundido entre eles (LANCASTER, 2008). O contexto contribuiu grandemente para esse fenômeno - além da crise econômica nos países subdesenvolvidos que agravou a pobreza e a desigualdade em meados dos anos de 1970 (e da fome na África e na Ásia do Sul), todas essas agências governamentais e multilaterais foram fortemente influenciadas pelas conferências internacionais que tiveram lugar durante a segunda metade do século XX e pelo aumento do número de ONGs proeminentes e influentes, que preconizam a cooperação para o desenvolvimento (VALENTIN, 2005).

Duas grandes visões sobre a ajuda externa para o desenvolvimento estavam em voga: a que defendia a redução das necessidades básicas (a pobreza, a fome, habitação) e aquela que via como inescapáveis os ajustes estruturais na economia (a reforma econômica, a liberalização comercial, a desvalorização da moeda etc.) a fim de promover o crescimento econômico (VALENTIN, 2005; LANCASTER, 2008). A primeira estava alinhada com as ONGs que proliferaram no período e a segunda foi associada com a abordagem dos burocratas do Banco Mundial. Independentemente das visões adotadas pelos doadores, o fato é que, em vinte anos, a ajuda aumentou dez vezes: de US $\$ 8$ bilhões em 1970 para quase US $\$ 80$ bilhões em 1990 (LANCASTER, 2008). 


\section{Debates Contemporâneos}

O fim da Guerra Fria representou grandes mudanças na ajuda externa e no conceito de desenvolvimento que deve guiar os fluxos de ajuda oficial. Temas como democratização, apoiando antigos países socialistas, problemas globais (os relacionados com os bens públicos globais) e a construção da paz em territórios pós-conflito são algumas das questões que ganharam terreno. A década de 1990 foi marcada por várias cúpulas das Nações Unidas com foco em problemas como meio ambiente, população, gênero, alimentação, mudanças climáticas globais, racismo (VALENTIN, 2005; LANCASTER, 2008).

A década de 1990 também marcou o início de uma revisão ampla e profunda do modelo contemporâneo de ajuda externa (revisão que se encontra ainda em curso), seja por estudiosos ou por burocratas das agências governamentais e multilaterais de ajuda (EASTERLY, 2008; LANCASTER, 2008; MOYO, 2009). Nas agências, surgem dúvidas sobre a eficácia da ajuda, a volatilidade dos fundos, críticas sobre auxílio financeiro a países geridos por regimes corruptos e violentos, falta de seletividade, má interpretação sobre os resultados esperados do auxílio financeiro prestado, gerando mal-estar entre doadores e destinatários - tais são algumas das questões levantadas nesse período. Além disso, a queda do Muro de Berlim potencializa os termos de condicionalidade nas doações internacionais. Não que as transferências feitas no período da Guerra Fria fossem totalmente incondicionais - sobretudo no caso da ajuda multilateral, a condicionalidade (aquele receituário fornecido pelo doador/credor para ser seguido à risca pelo país destinatário) sempre existiu. Mas, no período da Guerra Fria, a ajuda externa tinha propósitos geopolíticos de buscar assegurar zonas de influência, então não havia muitos termos de condicionalidade nas doações, já que os doadores entendiam que elas precisavam acontecer de toda forma. Já nos anos de 1980 e 1990, a concorrência entre países destinatários aumenta e a condicionalidade surge como uma marca forte da ajuda externa, seja bilateral ou multilateral (WRIGHT; WINTERS, 2010).

Os Objetivos de Desenvolvimento das Nações Unidas, estabelecidos em 2000, ou Objetivos do Milênio (Millenium Goals), também influenciaram os programas de ajuda dos países desenvolvidos em todo o mundo e o DAC até criou indicadores especiais para medir a eficácia da ajuda em relação aos ODM. Três conferências das Nações Unidas sobre Ajuda Externa para o Desenvolvimento ocorreram nos últimos 15 anos (Monterrey, no México, em 2002; Doha, no Qatar, 2008; e Adis 
Abeba, Etiópia, 2015). As três ocorreram com o apoio do Banco Mundial, do Fundo Monetário Internacional e da Organização Mundial do Comércio.

O Movimento dos Não-Alinhados passou por um período crítico nos anos de 1980, por conta da crise que se abateu sobretudo sobre os países da África e América Latina, que acumularam dívidas e, em alguns casos, chegaram a ter crescimento negativo, o que dificultou a colaboração entre eles. Sem alternativas, esses países tiveram que se render aos programas top-down de ajustes estruturais do Banco Mundial e do FMI, cujo receituário rígido lhes relegava pouca autonomia político-administrativa e econômica (MODI, 2009). Mas a cooperação entre países em desenvolvimento (cooperação Sul-Sul) ressurge nas décadas de 1990 e anos 2000, quando países considerados de renda média, como Brasil, Índia, México e África do Sul, passaram a intercambiar know-how de programas sociais bem-sucedidos nos seus respectivos territórios (SÁ e SILVA, 2009; BURGES, 2012).

Paralelamente, a China vem colaborando financeiramente para com os países da África Subsaariana desde o início do milênio (MOYO, 2009). Os recursos administrados aparecem sob a forma de "assistência/ajuda" (GUÉRIN, 2008; BRÄUTIGAM, 2011), "investimento" (MOYO, 2009) ou ainda "assistência econômica” (LUM, 2009). De fato, como explica Burger (2012), o caso chinês está entre aqueles em que é difícil estabelecer o limite entre ajuda externa e investimento, já que o programa da China na África é complexo e envolve não apenas a instalação de indústrias (sobretudo de mineração) e infraestrutura de escoamento de bens, mas também pequenas doações para gastos sociais e empréstimos com taxas de juros favoráveis (GUÉRIN, 2008). Embora seja visto por Moyo (2009) como um programa promissor em termos de forjar crescimento econômico nos países africanos e pelo caráter não paternalista de ajuda externa, parece haver um consenso entre autores no sentido de que tais recursos não cabem na definição de AOD da OCDE, ainda que possam de alguma forma ser considerados como voltados para o desenvolvimento, sendo uma das razões o fato de que o programa não é transparente (GUÉRIN, 2008; LUM, 2009; BRÄUTIGAM, 2011).

Na comunidade científica, o debate sobre ajuda externa vem se desdobrando em duas frentes: a frente dos que buscam as motivações para doar e a frente dos que medem o impacto das doações. No primeiro caso, autores dos mais diversos matizes teóricos procuram entender as razões que levam um país a doar recursos públicos para outro país. Ainda dentro desse enfoque, há uma discussão importante sobre a questão da seletividade, que trabalha no sentido de verificar os fatores que atraem e/ou afugentam doadores em países ou setores específicos. O objeto, 
nesse caso, é o doador. No segundo caso, os trabalhos medem o impacto da ajuda externa nos países destinatários, em uma variedade de assuntos, tais como em combate à corrupção, democratização, redução da pobreza, crescimento econômico, reformas institucionais e outros. O objeto, aqui, são os países destinatários. Em ambos os casos, os trabalhos transitam entre os campos da ciência política, relações internacionais e economia e há desde estudos quantitativos, com grande número de casos, a estudos de caso descritivos e bastante específicos ${ }^{10}$.

$\mathrm{O}(\mathrm{A})$ leitor(a) poderá se perguntar, ao longo da leitura das próximas seções, por que trabalhos sobre cooperação Sul-Sul (CSS) não foram incluídos. É importante esclarecer aqui que a revisão da literatura foi baseada em uma série de palavras-chave que permitiram também a listagem de trabalhos sobre a cooperação Sul-Sul. Contudo, tais trabalhos caracterizam a CSS como essencialmente técnica (BURGES, 2012; LANDAU, 2008) e frequentemente fruto de triangulação - quando um país desenvolvido financia o intercâmbio e/ou transferência de conhecimento/ tecnologia entre dois ou mais países em desenvolvimento (SÁ e SILVA, 2009; MUGGAH; CARVALHO, 2011). Não envolvem a transferência sistemática de fundos públicos entre países do Sul - o que também torna tal forma de cooperação mais difícil de ser quantificada (BURGES, 2012; SOUZA, 2014), já que muitas situações podem se enquadrar como CSS ${ }^{11}$. A definição com a qual trabalhei não comporta esse formato de cooperação e por isso não incluí os artigos que encontrei na classificação que segue ${ }^{12}$.

A leitura desses trabalhos pode render a impressão de que muitas das constatações dos pesquisadores são paradoxais e contraditórias. Mas é preciso atentar para o fato dos diferentes desenhos de pesquisa utilizados - amostras, enfoques temporais e espaciais, indicadores e metodologias. Conclusões generalizantes sobre ajuda externa empobrecem o debate sobre o assunto, pois estamos tratando de um universo de casos que tem, literalmente, o tamanho do mundo. Por essa razão, recortes muito bem definidos são necessários. Passaremos por esses debates nos dois subitens seguintes.

10 A revisão bibliográfica que redundou na redação dessa seção do artigo está baseada nas seguintes ferramentas de busca bibliográfica: Google Scholar, Jstor e Academia.edu. Foram ainda incorporados alguns trabalhos sugeridos pela(o)s pareceristas que julguei adequados à abordagem desenvolvida aqui.

11 Landau (2008) chega a incluir inclusive o perdão da dívida de países africanos e latino-americanos com o Brasil como forma de cooperação para o desenvolvimento.

12 Embora não se enquadre na definição com a qual estamos trabalhando aqui, não deixa de ser interessante explorar os múltiplos e criativos formatos de cooperação Sul-Sul. 


\section{Debate motivacional sobre ajuda externa}

As razões que explicam a ajuda externa foram tratadas principalmente nos anos de 1960 e 1970, no auge da Guerra Fria. Realistas entendem a ajuda externa como um instrumento para aumentar a segurança da nação doadora - e esse era o objetivo principal dos primeiros programas de ajuda ocidentais: reduzir as tentações do comunismo. Morgenthau (1962), em um artigo clássico sobre a ajuda externa, explica que a ela é um instrumento de poder político e deve ser utilizado para assegurar zonas de influência - no entanto, ele tem uma visão crítica sobre os resultados que tal ajuda pode desencadear. O autor entende a ajuda externa como "poder de compra", como recursos para comprar aliados e concessões - e ele também inclui subornos a título de ajuda. Morgenthau afirma que a ajuda nem sempre é eficaz (eficácia entendida como "pagar e obter o produto") e deve ser muito bem calculada. De fato, até meados dos anos de 1970, não havia outro debate possível sobre as motivações da ajuda externa oficial que não fosse aquele dominado pelo realismo. Como afirma Lancaster (2008), a ajuda externa nasce como instrumento estratégico da Guerra Fria e do realismo diplomático. Embora não mais dominem os trabalhos sobre ajuda externa, os realistas exercem ainda considerável importância nesse campo de estudos, como veremos na seção a seguir.

Já estudiosos da Cepal elaboraram, entre os anos de 1950 e 1960, o que veio a ser conhecida como a "teoria da dependência", que entendia o investimento externo como inibidor do desenvolvimento local e reprodutor do subdesenvolvimento na periferia capitalista. O livro Dependência e Desenvolvimento na América Latina (CARDOSO; FALETTO, 1970), embora não seja o único trabalho que desenvolve as ideias centrais da teoria, tiveram enorme influência nos países latino-americanos e em outros países do Sul, tendo sido traduzido para várias línguas. Esses estudos influenciaram e influenciam ainda trabalhos que interpretam a ajuda externa como um instrumento de intervenção e dominação para fins de exploração de países pobres. Relaciona-se a ajuda externa a uma forma de neocolonialismo/ recolonialismo (GHOSH, 1985; MURRAY, 2004; TANDON, 2008), um mecanismo que tende a criar (ou recriar) vínculos de dependência entre países doadores e países receptores da ajuda (aid dependency). Para Tandon (2008), a ajuda externa é uma forma de controle sobre as nações pobres que gera estigma e subserviência, além de desencorajar a busca pelo desenvolvimento. Sogge (2015) vai ainda mais adiante ao mostrar que os recursos transferidos aos países receptores retornam 
aos países doadores na forma de fluxo de capitais, mostrando que a ajuda externa se revela, na verdade, uma autoajuda.

Riddell (1987) defende que a localização do governo no espectro esquerda-direita influencia a quantidade e a natureza da ajuda. Ele afirma que, na Grã-Bretanha, tanto trabalhistas como conservadores têm uma visão pró-desenvolvimentista da ajuda externa, mas os primeiros são defensores da ajuda para as pessoas mais pobres nos países menos desenvolvidos; a segunda compreende a ajuda ao desenvolvimento como uma espécie de assistência com objetivo de criar ambiente para mercados abertos. Riddell explica que as mesmas considerações sobre a ajuda ao desenvolvimento se aplicam aos Estados Unidos no caso de democratas e republicanos. Na mesma linha de considerar as instituições e os valores domésticos como determinantes para a ajuda externa, Lumsdaine (1993) explica que os propósitos que orientam um determinado país doador seriam reflexo das normas e dos valores em curso de tal país. Sua análise faz sentido sobretudo se olharmos para a literatura que trabalha com a ajuda externa prestada por países com sistema de welfare state bastante desenvolvido. Noel e Thérien (1995), por exemplo, procuram demonstrar como a visão de justiça vigente no plano interno de países doadores, materializada em suas instituições domésticas, influencia no potencial doador desses países.

A partir dos anos de 1990, internacionalistas liberais começaram a escrever sobre a ajuda externa como resultado da interdependência contemporânea e uma ferramenta necessária para resolver os problemas relacionados aos "bens públicos" ou "bens globais", aqueles para os quais todos teriam direito, como segurança, meio ambiente, conhecimento, trabalho digno etc. (MILANI, 2014) e cuja má gestão pode levar a resultados catastróficos que atravessam fronteiras políticas e cruzam oceanos (como epidemias ou desastres gerados pelo aquecimento global). Tal conceito remonta à década de 1950 e foi sendo retrabalhado teoricamente durante toda a segunda metade do século XX e começou a ser incorporado em diversos documentos da ONU a partir dos anos de 1980 (SHUTTE, 2015). São vários os trabalhos que entendem que o maior desafio da ajuda externa atualmente é enfrentar os problemas transnacionais (KANBUR; SANDLER; MORRISON, 1999; JAYARAMAN; KANBUR, 1999).

Vale ressaltar que tais abordagens não são necessariamente excludentes. Propósitos neocolonialistas podem se coadunar perfeitamente com propósitos realistas. Assim como a abordagem segundo a qual os partidos e outras instituições domésticas desempenham papel importante na definição das doações pode ser bem 
trabalhada dentro de uma perspectiva de proteção dos bens públicos globais. E, para além da discussão sobre o que levaria países a doar, ou quais fatores pesam mais nessa decisão, há ainda o debate sobre o que faz com que doem para certos países em detrimento de outros, ou para alguns setores do desenvolvimento em detrimento de outros, ou para comunidades e ONGs em detrimento de governos. Essa questão ensejou uma literatura que compara tipos de doadores e cruza essa informação com características dos países destinatários - como grau de corrupção, qualidade das instituições, governança, tipo de regime político, respeito a direitos humanos etc.

Com efeito, alguns artigos interessantes apontam diferenças no desenvolvimento de atividades de agências bilaterais e multilaterais de ajuda. Maizels e Nissanke (1984) investigaram se as doações são guiadas por interesses do doador ou necessidades do destinatário. Eles encontram evidências de que a ajuda bilateral é mais guiada pelos interesses dos doadores e que a ajuda multilateral é mais guiada pelas necessidades do destinatário. Dollar e Levin (2006) examinam se a ajuda externa, bilateral e multilateral, é "seletiva” em termos de democracia e estado de direito - ou seja, em que medida o respeito a tais valores é levado em consideração por parte das agências doadoras. Eles concluem que a assistência multilateral é mais seletiva do que a ajuda bilateral - ou seja, o respeito à democracia e ao estado de direito por parte de países destinatários pesa mais nas decisões das agências multilaterais do que das agências bilaterais. Neumayer (2003a, 2003b, 2003c) endossa tal conclusão. Ele afirma que o histórico de um país em matéria de direitos humanos é muitas vezes estatisticamente insignificante como um determinante da concessão da ajuda, mas existem diferenças entre as alocações de ajuda de agências bilaterais e multilaterais. Apenas para as últimas o respeito aos direitos humanos é relevante.

Há ainda uma discussão sobre as agências fornecedoras de "créditos reembolsáveis" e “créditos não reembolsáveis” (HAMMERGREN, 2003). Os créditos reembolsáveis seriam os empréstimos e os não reembolsáveis, as doações. Segundo Hammergren (2003), há uma diferença na maneira de agir desses dois tipos de agências. Aquelas que fornecem créditos reembolsáveis - como o Banco Mundial e outros bancos de desenvolvimento regional - seriam mais sensíveis a demandas locais do que as agências fornecedoras de créditos não reembolsáveis - como as agências bilaterais de CID -, que tenderiam a condicionar a doação a um receituário genérico e engessado, pouco aberto ao diálogo com os governos ou organizações dos países destinatários. O texto de Hammergren corrobora as ideias 
dos autores trabalhados acima, já que a classificação que faz entre agências que fornecem créditos reembolsáveis e não reembolsáveis pode ser convertida, sem prejuízos, em uma classificação entre, respectivamente, agências multilaterais e bilaterais.

Easterly (2002), um estudioso que também é um ex-executivo do Banco Mundial, afirma que as agências de ajuda externa exigem demasiadamente dos países receptores, desconsiderando que muitos desses países, sobretudo os mais pobres, possuem instituições fracas e pouco consolidadas, além de não contar com recursos humanos adequados. Segundo o autor, essa fórmula leva ao fracasso certo. Easterly (2002) entende que é importante ouvir atores nos países beneficiários, a fim de evitar decepções. Tal opinião é partilhada com Berg (2000), para quem o fracasso na reforma das instituições políticas nos países receptores pode ser considerado uma deficiência dos doadores em adaptar programas e práticas para as circunstâncias dos países de baixa renda com instituições administrativas fracas. Nessa mesma linha, a crítica segundo a qual a comunidade de doadores cria fórmulas demasiadamente generalizantes para localidades muito distintas, do ponto de vista institucional, é partilhada por alguns autores que trabalham com programas de reforma do setor de segurança na América Latina (TUCHIN; GOLDING, 2003; ZIEGLER; NIELD, 2002).

Ainda no rol dos debates motivacionais sobre ajuda externa, trabalhos apontando motivações pouco elogiosas e mesmo perversas de algumas agências, bilaterais e multilaterais, são frequentes na literatura. Numa abordagem mais marxista, Petras (1997) explica que as ONGs e muitas das organizações internacionais atuantes na América Latina desde os anos de 1980 sobrevivem de recursos doados por agências norte-americanas e europeias que estiveram e estão a serviço do imperialismo ocidental, tendo introduzido um discurso antiestatista na América Latina transvestido de defesa da sociedade civil. Segundo o autor, muitas dessas ONGs internacionais constituem, na verdade, a "face comunitária" do neoliberalismo.

Há ainda uma quantidade respeitosa de trabalhos que denunciam projetos de alfabetização do Banco Mundial e da UNESCO voltados à África e ao Pacífico Sul como uma tentativa de dominação cultural e simbólica para facilitar a dominação econômica desses povos (WICKENS; SANDLIN, 2007; BIRAIMAH, 2005). A mesma crítica pode ser estendida ao projeto do Banco Mundial de financiamento de universidades africanas nos anos de 1970 e 1980, que resultaram no desmantelamento do ensino superior público nos países receptores dos fundos e o 
consequente barateamento da mão de obra (COLLINS; RHOADS, 2010; CAFFENTZIS, 2000). Podemos citar ainda o investimento da USAID no treinamento das polícias latino-americanas durante os anos de 1960 e 1970, período marcado por vários governos ditatoriais e violentos no continente (MOTTA, 2010). Ainda sobre a USAID, os acordos MEC-USAID - série de doze acordos assinados entre o ministério da Educação brasileiro e a agência de cooperação norte-americana entre as décadas de 1960 e 1970 - visavam à adequação do ensino público brasileiro à formação de mão de obra para escorar o desenvolvimento econômico e foram intensamente criticados pelo movimento estudantil e intelectuais do período (CUNHA; GÓES, 1986; PINA, 2011). Vale lembrar que tais acordos foram assinados no período da Guerra Fria, quando a USAID trabalhou intensamente para conter o avanço comunista no globo, o que significa que uma educação mais técnica, profissionalizante e alinhada às demandas do mercado constituía um bom argumento para a redução da carga horária de disciplinas de cunho humanista, mais críticas e reflexivas. De fato, os acordos MEC-USAID orientaram as reformas do ensino ocorridas nos primeiros anos da ditadura militar no Brasil, que redundaram na eliminação de um ano de estudos da grade escolar de então (de doze para onze anos), na redução da carga horária de disciplinas como História e Geografia, além da retirada de Filosofia da grade, entre outras coisas (FONSECA, 2003; ARANHA, 1994).

Tratando ainda de motivações perversas e às vezes corruptivas, o jornalista Peter Gill (2016) chama a atenção em livro publicado recentemente para a captura política de ONGs internacionais e órgãos das Nações Unidas - como UNICEF e UNHCR - pelo Conselho de Segurança da ONU nas localidades em que ocorre a chamada guerra ao terror. O autor explica que organizações respeitadas historicamente por seu trabalho humanitário vêm sofrendo pressão das agências financiadoras - agências oficiais dos mesmos países que financiam a guerra ao terror - para seguirem uma agenda de trabalho que não condiz com aquela apregoada por essas organizações e nem com os princípios do trabalho humanitário.

\section{A discussão sobre o impacto da ajuda externa nos países destinatários}

Os trabalhos sobre o impacto da ajuda externa são bem mais abundantes do que aqueles que exploram as motivações para que ela ocorra. Alguns autores analisam o impacto da ajuda externa sob a ótica realista da "capacidade de compra" dos países doadores para com países beneficiários em votações da ONU, associando países beneficiários a concessões específicas (WANG, 1999; KEGLEY; HOOK, 1991; 
KUZIEMKO; WERKER, 2006; DREHER; NUNNENKAMP; THIELE, 2008). A maioria desses estudos analisa a capacidade dos investimentos norte-americanos para controlar os votos dos países beneficiários nas conferências, Assembleia Geral e conselhos das Nações Unidas. E a maioria deles aponta para a correlação positiva entre a ajuda e alinhamento do voto com os EUA, o que demonstra a eficácia da ajuda externa na “compra” dos votos dos países em desenvolvimento.

A relação entre ajuda externa e corrupção é trabalhada por Tavares (2003). O autor calcula a distância geográfica e cultural entre países doadores e receptores e conclui que a ajuda externa reduz a corrupção nos países receptores, mas que esse efeito é maior quando os países estão mais próximos geograficamente e culturalmente. Um estudo quantitativo com vários países doadores e receptores também foi feito por Okada e Samreth (2012) e concluiu que a ajuda externa geralmente reduz a corrupção, mas tal efeito de redução é maior em países que já são menos corruptos e pode variar de acordo com os países doadores. Essa visão otimista não é compartilhada por Alesina e Weder (1999), que documentam que, de acordo com alguns indicadores de corrupção, governos corruptos recebem mais ajuda que os não corruptos e não há evidência de que o aumento da ajuda externa reduz a corrupção.

No campo da relação entre ajuda externa e democracia, Kosack (2003) pesquisa o efeito da ajuda externa na qualidade de vida de habitantes em democracias e autocracias e conclui que a ajuda é mais eficaz quando aplicada em democracias, sugerindo que a ajuda externa devesse centrar fogo na democratização de países não democráticos. Knack (2004), porém, produz análise multivariada do impacto da ajuda sobre a democratização em uma grande amostra de países beneficiários, durante o período 1975-2000, e não encontra evidências de que a ajuda externa seja capaz de promover democracia. Finkel, Pérez-Liñán e Seligson (2007) estudaram programas de ajuda externa destinados a aumentar a democracia, tendo os EUA como doador em 165 países beneficiários entre 1990-2003. Os autores concluem que a assistência à democracia tem um impacto positivo significativo na democratização dos países receptores.

Vale ressaltar o papel da condicionalidade das doações no impacto dessa ajuda nos países receptores. Alguns críticos entendem que a condicionalidade é simplesmente ineficiente para induzir crescimento econômico (EASTERLY, 2005). Há outros que veem no receituário proposto pelas agências de financiamento um atentado à soberania dos países destinatários e uma forma de neocolonialismo paternalista (MURRAY, 2004), mas há trabalhos que evidenciam a efetividade 
da condicionalidade. Dunning (2004) constata que o pequeno efeito positivo da ajuda externa ocidental na democratização de países africanos subsaarianos está limitado ao pós-Guerra Fria, sendo esse um indicador de que o efeito da ajuda externa está condicionado pelo contexto geopolítico - com a ausência do bloco soviético na disputa por zonas de influência, a ameaça de interromper os fluxos assistenciais por parte de doadores ocidentais leva países destinatários a seguir o receituário imposto pela agência doadora. Bearce e Tirone (2010) chegam a uma conclusão parecida no que tange ao crescimento econômico. Eles demonstram que a ajuda fornecida por países ocidentais só promoveu crescimento econômico depois dos anos de 1990, uma vez que o fim da Guerra Fria possibilitou aos países doadores condicionar as doações às reformas que entendiam como necessárias nos países destinatários.

De todos os impactos supostamente causados pela ajuda externa, os mais trabalhados pela literatura são, de longe, aqueles relacionados ao crescimento econômico e à redução da pobreza. Com relação ao crescimento econômico, alguns trabalhos são bem pessimistas no sentido de demonstrarem que a soma dos volumes destinados aos países em desenvolvimento ao longo dos últimos 60 anos é gigantesca e que o crescimento econômico gerado é incremental (WRIGHT e WINTERS, 2010). Por outro lado, desagregar os dados por tipo de ajuda, tipo de doador, setor e país de destino pode ajudar a obter dados mais apurados. Burnside e Dollar (1997) alegam que a ajuda externa oficial só tem efeito quando o país destinatário apresenta algumas pré-condições, como boas políticas monetárias e fiscais. Alguns pesquisadores notam que o efeito sobre o crescimento econômico pode estar relacionado ao tipo e ao período da ajuda - se de curto ou longo prazo (CLEMENS; RADELET; BHAVNANI 2004; RAJAN; SUBRAMANIAN'S, 2008). Knack (1999) nota ainda que o volume da ajuda tem efeito sobre o crescimento econômico, tendo constatado que quanto maior o montante da ajuda, menor o impacto sobre o crescimento econômico - segundo o autor, altas somas injetadas em um mesmo país tem efeito deletério sobre a governança, reduzindo a transparência das ações governamentais e gerando focos de corrupção e dependência de ajuda externa. Ainda sobre crescimento econômico, Easterly (2003) aponta que a ajuda não é capaz de promover o crescimento em grande escala e as agências devem estabelecer metas mais modestas, ao invés de buscarem ser catalisadoras da transformação de toda a sociedade.

No caso do impacto da ajuda externa oficial na redução da pobreza, há uma distinção entre autores que trabalham com uma definição econômica de 
pobreza (como renda per capita) e aqueles que trabalham com indicadores de desenvolvimento humano, como mortalidade infantil e analfabetismo. No primeiro caso, destacam-se os autores que criam modelos de efetividade da ajuda externa na redução da pobreza, baseados no argumento de que o atual modelo de fluxo de recursos destinados ao combate à pobreza é ineficiente, seja porque não beneficia os mais pobres (COLLIER; DOLLAR, 2002), seja porque não recompensam países que apresentam boas iniciativas (BURNSIDE; DOLLAR, 1998; COLLIER; DOLLAR, 2001), seja porque não levam em consideração a questão da promoção da igualdade de renda e de oportunidades na distribuição dos recursos (COGNEAU; NAUDET, 2007).

No segundo caso, uma pesquisa interessante concluiu, na década de 1990, que a ajuda externa não aumenta significativamente o crescimento econômico, nem beneficia os pobres, mas aumenta o tamanho do governo - o que não pode ser visto como um bom ou mau indicador em si (BOONE, 1996). Além disso, o autor da pesquisa conclui que o fato do país ser democrático ou repressivo não tem efeito significativo sobre o impacto da ajuda, mas governos liberais e democracias que receberam auxílios reduziram suas taxas de mortalidade média infantil 30\% mais do que os regimes repressivos. Já Yontcheva e Masud (2005) trabalham com o efeito da ajuda externa proveniente de doadores bilaterais e ONGs internacionais sobre a mortalidade infantil e o analfabetismo. Constatam que projetos financiados por ONGs internacionais têm impacto positivo maior sobre a mortalidade infantil do que aquele verificado nos projetos financiados por agências bilaterais, mas há pouca diferença com relação ao impacto sobre o analfabetismo. Verificam ainda que a entrada de recursos provenientes da ajuda bilateral pode levar países a substituir programas governamentais pelos projetos que se desenvolvem no âmbito do acordo bilateral, substituição tal que não ocorre no caso nos projetos financiados pelas ONGs internacionais. Já o trabalho de McGilllivray e Noorbakhsh (2007) busca cruzar informações de ajuda externa com IDH em países em conflito, a fim de verificar se os recursos recebidos são capazes de minimizar o efeito dos conflitos sobre o bem-estar da população desses países. Concluem que a ajuda está negativamente associada aos indicadores de IDH, o que significa que ela não consegue reduzir ou neutralizar o impacto dos conflitos sobre o bem-estar da população.

Além dessas macrodiscussões acima, que são geralmente baseadas em estudos quantitativos com grandes amostras, numerosos estudos de caso também surgiram nos últimos 25 anos. Há farta literatura tratando de países destinatários 
em conjunto ou receptores específicos, tendo programas ou agências em particular como objeto de pesquisa. É possível encontrar trabalhos em diferentes idiomas, pois os casos estudados são geralmente locais. É interessante conhecê-los porque introduzem uma análise da ajuda externa sob a perspectiva dos receptores, algo que não concorre com o mainsteam da produção acadêmica nesse campo.

Podemos citar o trabalho de Nipassa (2009), pesquisador moçambicano que analisa os efeitos da ajuda externa sobre o país africano desde a independência do mesmo em 1975. O autor discute os efeitos perversos da concessão de ajuda externa a Moçambique no longo prazo, explicando que o volume de recursos vem aumentando desde então e que esses montantes não foram capazes de reduzir a pobreza ou aumentar os indicadores de desenvolvimento. Pelo contrário: o resultado que vem sendo observado é um aumento da dependência econômica do país em relação aos recursos externos, tornando o povo moçambicano subserviente e desempoderado. Khan e Amhed (2007) avaliam que o impacto que a ajuda externa teve no Paquistão desde sua independência, em 1947, foi insignificante e concluem que não há relação entre a ajuda recebida e crescimento econômico nesse país. Para eles, a melhoria das condições para o investimento doméstico poderia atrair investimento externo direto e, então, gerar crescimento. A ideia de que a ajuda externa gera dependência econômica e limita o progresso de países receptores está presente em diversos trabalhos, boa parte dos quais produzidos nos países receptores da ajuda, sobretudo no que tange aos países da África (MOYO, 2009; LUMUMBA-KASONGO, 2011; TANDON, 1991), ilhas do Pacífico Sul (CONNEL, 1991; CONNEL 2006; CAMPBELL, 1992).

\section{Conclusões}

Este artigo foi escrito com a intenção de introduzir o leitor à discussão sobre ajuda externa. O objetivo era traçar um histórico contextualizado e situar o leitor no âmbito dos principais debates acadêmicos relacionados ao tema. Segundo Ayllón (2006), a literatura acadêmica sobre ajuda externa é hoje bastante extensa internacionalmente e os debates fomentados refletem uma agenda de pesquisa consolidada na América do Norte e Europa. O tema parece não despertar, entretanto, o mesmo interesse no Brasil.

O que se nota a partir desse levantamento é que não há análises conclusivas sobre as motivações e o impacto da ajuda externa. Um ponto interessante é que, 
num primeiro momento, as experiências analisadas parecem corroborar a tese de Easterly (2003), segundo a qual a ajuda externa não foi capaz de desencadear mudanças estruturais positivas e significativas nos países destinatários, no que tange principalmente à redução da pobreza e ao crescimento econômico. O fato é que o rol de programas financiados com ajuda externa, de países doadores e de países receptores é enorme e é bem possível que haja muitas experiências ainda subanalisadas. Se houvesse a possibilidade de ter todos os programas analisados, talvez chegássemos à conclusão de que uma parte foi bem-sucedida e outra, não.

Um dado que chamou atenção é o fato de não terem aparecido muitos trabalhos analisando o impacto da ajuda externa em questões ambientais. Estou certa de que tais trabalhos existem. O fato é que minha revisão tomou por base os temas mais frequentes no debate sobre ajuda externa, entendidos como aqueles que aparecem mais assiduamente nas buscas bibliográficas. No levantamento que empreendi, não privilegiei nenhum corte setorial e a maior parte dos trabalhos que surgiram analisavam o impacto da ajuda externa oficial na redução da pobreza ou no crescimento econômico, o que denota que tal discussão está dominada por esses temas.

Outra questão que merece destaque é o fato de que a maior parte do que é produzido no campo da ajuda externa foi escrito por acadêmicos que fazem parte dos países que se encontram dentro da comunidade de doadores (os DAC members). Não é fácil encontrar material produzido por pesquisadores dos países destinatários - não sabemos se isso se deve ao fato de não serem acessíveis, de não se encontrarem disponíveis em bases e/ou indexadores bibliográficos ou motores de busca acadêmica comumente utilizados, ou se há realmente pouca produção a respeito. Contudo, ainda que tal produção seja incipiente, entendemos que é preciso buscá-la e mesmo estimulá-la, pois a perspectiva dos países destinatários sobre a ajuda externa parece destoar bastante da literatura dominante sobre o tema e oferecer uma abordagem mais crítica e reflexiva sobre o assunto.

\section{Referências}

AGÊNCIA FRANCESA DE DESENVOLVIMENTO (AFD): arquivos virtuais da AFD. Disponível em: < http://www.afd.fr/home/AFD/presentation-afd/GouvernanceAFD/ Historique-et-statuts $>$. Acesso em: jun. 2016.

ALESINA, Alberto; WEDER, Beatrice. Do corrupt governments receive less foreign aid?. National Bureau of Economic Research, 1999. 
ARANHA, Maria Lúcia de Arruda. História da educação. Moderna, 1994.

AYLLÓN, Bruno. O sistema Internacional de Cooperação ao Desenvolvimento e seu estudo nas Relações Internacionais: a evolução histórica e as dimensões teóricas. Revista de Economia e Relações Internacionais. Vol. 5 nº 8, 2006, pags. 5-23.

BANCO MUNDIAL: arquivos virtuais do Banco Mundial. Disponível em: < http://www. worldbank.org/en/about/archives/history > . Acesso em: jun. 2016.

BANCO INTERAMERICANO DE DESENVOLVIMENTO (BID): arquivos virtuais do BID. Disponível em: < http://www.iadb.org/en/about-us/history-of-the-inter-americandevelopment-bank,5999.html > . Acesso em: jun. 2016.

BARDER, Owen. Reforming Development Assistance: Lessons from the UK Experience. Working Paper $n^{\circ}$ 70. Center for Global Development, October, 2005. Disponível em: < http://www.cgdev.org/files/4371_file_WP_70.pdf >. Acessado em: 06 jun. 2016.

BAYLEY, David. Changing the Guard. Nova York, Oxford University Press, 2006.

BEARCE, David H.; TIRONE, Daniel C. Foreign aid effectiveness and the strategic goals of donor governments. The Journal of Politics, v. 72, n. 03, 2010, p. 837-851

BERG, E. Aid and failed reforms. Foreign Aid and Development: Lessons Learnt and Directions for the Future, 2000, p. 363-380.

BIRAIMAH, Karen. Achieving equitable outcomes or reinforcing societal inequalities? A critical analysis of UNESCO's Education For All and the United States' No Child Left Behind Programs. Educational Practice and Theory, v. 27, n. 2, 2005, p. 25-34

BOONE, Peter. Politics and the effectiveness of foreign aid. European economic review, v. 40, n. 2, 1996, p. 289-329.

BRÄUTIGAM, Deborah. Aid 'With Chinese Characteristics': Chinese Foreign Aid and Development Finance Meet the OECD-DAC Aid Regime. Journal of international development, v. 23, n. 5, 2011, p. 752-764.

BURGES, Sean W. Developing from the South: South-South cooperation in the global development game. Austral: Brazilian Journal of Strategy \& International Relations, v. 1, n. 2, 2012, p. 225-249.

BURNSIDE, Craig; DOLLAR, David. Aid, Policies and Growth. World Bank Policy Research Working Paper n ${ }^{\circ}$ 569252, 1997.

BURNSIDE, Craig; DOLLAR, David. Aid, the incentive regime, and poverty reduction. World Bank Publications, 1998.

CAFFENTZIS, George. The world bank and education in Africa. In: FEDERICI, Silvia; CAFFENTZIS, George; ALIDOU, Ousseina (Ed.). A Thousand Flowers: Social struggles against structural adjustment in African Universities, Asmara: Africa World Press, 2000, Chapter 1, p. 3-18.

CAMPBELL, Ian C. A historical perspective on aid and dependency: the example of Tonga. Pacific Studies, v. 15, n. 3, 1992, p. 59-75. 
CARDOSO, Fernando Henrique.; Faletto, Enzo. Dependência e Desenvolvimento na América Latina. Editora Civilização Brasileira, São Paulo, 1970.

CLEMENS, Michael A.; RADELET, Steven; BHAVNANI, Rikhil R. Counting chickens when they hatch: The short term effect of aid on growth. Center for Global Development working paper, n. 44, 2004.

COGNEAU, Denis; NAUDET, Jean-David. Who deserves aid? Equality of opportunity, international aid, and poverty reduction. World Development, v. 35, n. 1, 2007, p. 104-120.

COLLIER, Paul; DOLLAR, David. Can the world cut poverty in half? How policy reform and effective aid can meet international development goals. World development, v. 29, n. 11, 2001, p. 1787-1802.

COLLIER, Paul; DOLLAR, David. Aid allocation and poverty reduction. European Economic Review, v. 46, n. 8, 2002, p. 1475-1500.

COLLINS, Christopher S.; RHOADS, Robert A. The World Bank, support for universities, and asymmetrical power relations in international development. Higher Education, v. 59, n. 2, 2010, p. 181-205.

CONNELL, John. The new Micronesia: pitfalls and problems of dependent development. Pacific Studies, v. 14, n. 2, 1991, p. 87-120.

CONNELL, John. Migration, dependency and inequality in the Pacific: Old wine in bigger bottles? (Part 1). In: FIRTH, Steward (Ed.). Globalisation and governance in the Pacific Islands: State, Society and Governance in Melanesia Studies in State and Society in the Pacific, No. 1, Canberra: Australian National University, 2006, p. 59-80. CUNHA, Luiz Antônio; GOES, Moacyr. O golpe na educação. Zahar, 1986.

DOLLAR, David; LEVIN, Victoria. The increasing selectivity of foreign aid, 1984-2003. World development, v. 34, n. 12, 2006, p. 2034-2046.

DREHER, Axel; NUNNENKAMP, Peter; THIELE, Rainer. Does US aid buy UN general assembly votes? A disaggregated analysis. Public Choice, v. 136, n. 1-2, 2008, p. 139-164.

DUNNING, Thad et al. Conditioning the effects of aid: Cold War politics, donor credibility, and democracy in Africa. International Organization, v. 58, n. 2, 2004, p. 409-423.

EASTERLY, William. The cartel of good intentions: the problem of bureaucracy in foreign aid. The Journal of Policy Reform, v. 5, n. 4, 2002, p. 223-250.

EASTERLY, William. Can foreign aid buy growth?. The journal of economic perspectives, v. 17, n. 3, 2003, p. 23-48.

EASTERLY, William. What did structural adjustment adjust?: The association of policies and growth with repeated IMF and World Bank adjustment loans. Journal of development economics, v. 76, n. 1, 2005, p. 1-22.

EASTERLY, William (Ed.). Reinventing foreign aid. Cambridge: The MIT Press, 2008. 
FARIA, Lina; COSTA, Maria Conceição. Cooperação científica internacional: estilos de atuação da Fundação Rockefeller e da Fundação Ford. Dados, Vol. 49, n 1, 2006, p. 159-191.

FINKEL, Steven E.; PÉREZ-LIÑÁN, Aníbal; SELIGSON, Mitchell A. The effects of US foreign assistance on democracy building, 1990-2003. World Politics, v. 59, n. 03, 2007, p. 404-439.

FONSECA, Selva Guimarães. Didática e prática de ensino de História. São Paulo: Papirus Editora, $7^{\text {a }}$ edição, 2003.

GABINETE DE PLANEAMENTO, ESTRATÉGIA, AVALIAÇÃO E RELAÇÕES INTERNACIONAIS DO MINISTÉRIO DAS FINANÇAS DE PORTUGAL (GPEARI): arquivos virtuais do Gpeari. Disponível em: < http://www.gpeari.min-financas.pt/relacoes-internacionais/ relacoes-multilaterais/instituicoes-financeiras-internacionais/bancos-regionais-dedesenvolvimento > . Acesso em: jun. 2016.

GHOSH, B. N. Political economy of neocolonialism in Third World countries. New Delhi: Sterling, 1985.

GILL, Peter. Today we drop bombs, tomorrow we build bridges: how foreign aid became a casualty of war. Londres: Zed Books, 2016.

GUÉRIN, Émmanuel. Chinese assistance to Africa: characterization and position regarding the global governance of development aid. IDDRI - Idées pour le débat, $\mathrm{n}^{\circ} 3,2008$, p. 1-10.

HAMMERGREN, Linn. International Assistance to Latin American Justice Programs: Toward an Agenda for Reforming the Reformers. In: JENSEN, Ericket; HELLER, Thomas (Ed.), Beyond common knowledge: empirical approaches to the rule of law. Stanford: Stanford University Press, 2003. Chapter 9, p. 290-335.

JAPAN INTERNATIONAL COOPERATION AGENCY (JICA): arquivos virtuais da JICA. Disponível em: < http://www.jica.go.jp/english/about/history/ > . Acesso em: jun. 2016.

JAYARAMAN, Rajshri; KANBUR, Ravi. International public goods and the case for foreign aid. Working Paper 99-05. Department of Agricultural, Resource, and Managerial Economics, Cornell University, 1999.

KANBUR, Ravi; SANDLER, Todd; MORRISON, Kevin. The future of development assistance: common pools and international public goods. Policy Essay $\mathrm{n}^{\circ} 25$. Washington, DC: Overseas Development Council, 1999.

KEGLEY, Charles W.; HOOK, Steven W. US foreign aid and UN voting: did Reagan's linkage strategy buy deference or defiance?. International Studies Quarterly, v. 35, n. 3, 1991, p. 295-312.

KHAN, Muhammad Arshad; AMHED, Ayaz. Foreign Aid-Blessing or Curse: Evidence from Pakistan. The Pakistan Development Review, vol. 46, nº 3, 2007, p. 215-240. 
KNACK, Stephen. Aid Dependence and the Quality of Governance: A Cross-Country Empirical Analysis. World Bank Policy Research Working Paper, n. 2396, 1999.

KNACK, Stephen. Does foreign aid promote democracy?. International Studies Quarterly, v. 48, n. 1, 2004, p. 251-266.

KOSACK, Stephen. Effective aid: How democracy allows development aid to improve the quality of life. World Development, v. 31, n. 1, 2003, p. 1-22.

KUZIEMKO, Ilyana; WERKER, Eric. How much is a seat on the Security Council worth? Foreign aid and bribery at the United Nations. Journal of political economy, v. 114, n. 5, 2006, p. 905-930.

LANCASTER, Carol. Foreign aid: Diplomacy, development, domestic politics. University of Chicago Press, 2008.

LANDAU, Georges. O Brasil e a cooperação internacional para o desenvolvimento. Revista de Economia e Relações Internacionais. Vol. 6, $\mathrm{n}^{\circ}$ 12, 2008, p. 103-116.

LOCHE, Adriana Alves. Segurança e controle social: uma análise do policiamento comunitário. 2012. 191 f. Tese (Doutorado em Sociologia). Faculdade de Filosofia, Letras e Ciências Humanas, Universidade de São Paulo, São Paulo. 2012.

LUM, Thomas. China's assistance and government-sponsored investment activities in Africa, Latin America, and Southeast Asia. Washington DC: Congressional Research Service, 2009.

LUMSDAINE, David Halloran. Moral vision in international politics: the foreign aid regime, 1949-1989. Princeton: Princeton University Press, 1993.

LUMUMBA-KASONGO, Tukumbi. China-Africa relations: A neo-imperialism or a neo-colonialism? A reflection. African and Asian Studies, v. 10, n. 2-3, 2011, p. 234-266.

MAIZELS, Alfred; NISSANKE, Machiko K. Motivations for aid to developing countries. World Development, v. 12, n. 9, p. 879-900, 1984.

MARINHO, Maria Gabriela. Norte-americanos no Brasil: uma história da Fundação Rockefeller na Universidade de São Paulo, 1934-1952. São Paulo: Editora Autores Associados, 2001.

McGILLIVRAY, Mark; NOORBAKHSH, Farhad. Aid, conflict and human development. Working Papers 2007-03, Department of Economics, University of Glasgow, 2007.

MILANI, Carlos. Evolução histórica da cooperação Norte-Sul. In: SOUZA, André de Melo. Repensando a cooperação internacional para o desenvolvimento, Brasília (DF): Ipea. Capítulo 2, p. 33-56, 2014.

MODI, Renu (Ed.). South-South Cooperation: Africa on the Centre Stage. Basingstoke: Palgrave Macmillan, 2011.

MORGENTHAU, Hans. A Political Theory of Foreign Aid. The American Political Science Review, vol. LVI, n 2, 1962, p. 301-309. 
MOTTA, Rodrigo Patto Sá. Modernizando a repressão: a Usaid e a polícia brasileira. Revista Brasileira de História, v. 30, n. 59, 2010, p. 237-266.

MOYO, Dambisa. Dead aid: Why aid is not working and how there is a better way for Africa. New York: Farrar, Straus and Giroux, 2009.

MUGGAH, R., CARVALHO, I.S. O Efeito Sul: reflexões críticas sobre o engajamento do Brasil com Estados Frágeis. Revista Brasileira de Segurança Pública, vol. 5, n 2 , 2011, 390-400.

MURRAY, W. E. Neocolonialism. Encyclopedia of International Development. London: Routledge, 2004.

NEUMAYER, Eric. Is respect for human rights rewarded? An analysis of total bilateral and multilateral aid flows. Human Rights Quarterly, v. 25, n. 2, 2003a p. 510-527.

NEUMAYER, Eric. Do Human Rights Matter in Bilateral Aid Allocation? A Quantitative Analysis of 21 Donor Countries*. Social Science Quarterly, v. 84, n. 3, 2003b, p. 650-666. NEUMAYER, Eric. The determinants of aid allocation by regional multilateral development banks and United Nations agencies. International Studies Quarterly, v. 47, n. 1, 2003c, p. 101-122.

NIPASSA, Orlando. Ajuda externa e desenvolvimento em Moçambique: Uma perspectiva crítica. In: II Conferência IESE. Dinâmicas da pobreza e padrões de acumulação econômica em Moçambique. 2009.

NOEL, Alain; THÉRIEN, Jean-Philippe. From domestic to international justice: The welfare state and foreign aid. International organization, v. 49, n. 03, 1995, p. 523-553.

ORGANIZAÇÃO PARA A COOPERAÇÃO E DESENVOLVIMENTO ECONÔMICO (OCDE): DAC in Dates: The History of OCDE's Development Assistance Committee. Disponível em: < http://www.OCDE.org/dac/1896808.pdf > . Acesso em: jun. 2016.

ORGANIZAÇÃO PARA A COOPERAÇÃO E DESENVOLVIMENTO ECONÔMICO (OCDE): Arquivos virtuais da OCDE. Disponível em: < http://www.oecd.org/dac/stats/ the07odagnitarget-ahistory.htm > . Acesso em: mar. 2017.

OKADA, Keisuke; SAMRETH, Sovannroeun. The effect of foreign aid on corruption: A quantile regression approach. Economics Letters, v. 115, n. 2, 2012, p. 240-243.

PETRAS, James. Imperialism and NGOs in Latin America. Monthly review, v. 49, n. 7 , 1997, p. 10-27.

PINA, Fabiana. O acordo MEC-USAID: ações e reações (1966-1968). 2011. 187-f. Dissertação (Mestrado em História). Programa de Pós-Graduação em História da UNESP de Assis. Assis, 2011.

RAJAN, Raghuram G.; SUBRAMANIAN, Arvind. Aid and growth: What does the cross-country evidence really show? The Review of economics and Statistics, v. 90, n. 4, 2008, p. 643-665. 
RIDDELL, Roger C. et al. Foreign aid reconsidered. Overseas Development Institute, 1987. SÁ e SILVA, Michelle. South-South Cooperation in Times of Global Economic Crisis. One Pager, v. 76, International Policy Centre for Inclusive Growth, 2009.

SCHUTTE, Giorgio Romano. Bens Públicos Globais: Entre a Diplomacia Multilateral e a Soberania Nacional. Paper apresentado no $5^{\circ}$ Encontro Nacional ABRI Belo Horizonte, PUC-Minas, 29-31 de julho de 2015. Disponível em: file://C:/Users/Ana\%20Maura/ Downloads/2015.06.17ABRI_Artigo.pdf > . Acessado em: 14 mar. 2017.

SOGGE, David. Los donantes se ayudan a sí mismos. Cuadernos $\mathrm{n}^{\circ} 6$ - Colección Cuadernos 2015 y más. Madrid: 2015 y más, 2015.

SOUZA, André de Melo. Repensando a cooperação internacional para o desenvolvimento. Em: SOUZA, André de Melo (org). Repensando a cooperação internacional para o desenvolvimento. Brasília (DF): Ipea, 2014. Capítulo 1, p. 11-32.

TANDON, Yash. Foreign NGOs, uses and abuses: An African perspective. IFDA dossier, n. 81,1991 , p. 67-78.

TANDON, Yash. Ending aid dependence. Cape Town: Fahamu Books, 2008.

TAVARES, Jóse. Does foreign aid corrupt?. Economics Letters, v. 79, n. 1, 2003, p. 99-106. TULCHIN, J. S., GOLDING, H.A. Introduction: Citizen Security in Regional Perspective. In: FRUHLIN, H., TULCHIN, J.S. and GOLDING, H.A. (eds.). Crime and Violence in Latin America: citizen security, democracy and State. Washington: Woodrow Wilson Center Press. 2003. Chapter 1, p. 1-12.

VALENTIN, E. La coopération internationale au développement : un vecteur de développement durable? Québec, Canada: Institut québécois des hautes études internationales - Université Laval, 2005.

WANG, Te-Yu. US foreign aid and UN voting: An analysis of important issues. International Studies Quarterly, v. 43, n. 1, 1999, p. 199-210.

WICKENS, Corrine M.; SANDLIN, Jennifer A. Literacy for what? Literacy for whom? The politics of literacy education and neocolonialism in UNESCO and World Bank-sponsored literacy programs. Adult Education Quarterly, v. 57, n. 4, 2007, p. 275-292.

WRIGHT, Joseph; WINTERS, Matthew. The politics of effective foreign aid. Annual Review of Political Science, v. 13, 2010, p. 61-80.

YONTCHEVA, Boriana; MASUD, Nadia. Does foreign aid reduce poverty? Empirical evidence from nongovernmental and bilateral aid. Working Paper 05-100. Washington: International Monetary Fund, 2005.

ZIEGLER, M., NIELD, R. From Peace to Governance: Police Reform and the International Community. Washington: John Hopkins University, 2012. 


\title{
O fenômeno dos "Estados emergentes" na política internacional contemporânea: contribuições da Economia Política Internacional para um objeto multi-aspectual
}

\author{
The phenomenon of the "Emergent Countries" \\ in the contemporary international politics: \\ contributions from International Political Economy \\ for a multi-aspectual object
}

DOI: $10.21530 /$ ci.v12n1.2017.615

Marina Scotelaro ${ }^{1}$

\section{Resumo}

A discussão do artigo se situa dentro do debate contemporâneo sobre a categorização de potências emergentes no capitalismo global, um fenômeno cada vez mais problematizado acerca da ascensão política e expressivo crescimento econômico dos Estados em desenvolvimento do Sul Global. A despeito da preexistência de um debate dentro de correntes tradicionais de relações internacionais, o resgate e a consolidação desses esforços analíticos no início do século XXI permitiram às teorizações econômicas uma crescente influência nos esforços interpretativos sobre tal aspecto do ambiente internacional. Entende-se que as abordagens interpretativas de relações internacionais que partem da economia política internacional fornecem atributos consistentes e são adequadamente correlacionados para compreender o posicionamento de países com crescente projeção internacional. Os avanços interpretativos possibilitaram novas compreensões sobre os fenômenos, mas a tentativa de dimensionar os Estados segundo sua potencialidade de influenciar na política internacional se torna problemática em função do seu nível de integração à economia capitalista global.

Palavras-chave: Estados Emergentes, Economia política internacional, Capitalismo, Governança Global.

1 Doutoranda em Relações Internacionais na PUC Minas; professora de Relações Internacionais no Centro Universitário de Belo Horizonte (UniBH). E-mail: marinascotelaro@gmail.com

Artigo submetido em 31/01/2017 e aprovado em 19/04/2017. 


\begin{abstract}
The discussion of this article is inserted into the contemporary debate about the categorization of Emerging powers in global capitalism, an increasingly problematized phenomenon regarding the political rise and significant economic growth of the developing States in the Global South. Despite the preexistence of a debate within traditional theories of International Relations, the recovery and the consolidation of these analytical efforts in the early twenty-first century allowed economic theorization a growing influence on interpretive efforts of this aspect of the international system. We believe that the interpretative approaches to International Relations derived from International Political Economy provide consistent attributes and are properly correlated to understand the positioning of countries with growing international projection. Interpretative advances made new understandings of the phenomena possible, but the attempt to scale the States by their capacity to influence international politics can become problematic depending on its level of integration into the global capitalist economy.
\end{abstract}

Keywords: Emergent States; Political Economy, Capitalism, Global governance.

\title{
Introdução
}

Um dos fenômenos da política internacional contemporânea com grande relevância nas relações internacionais é a crescente visibilidade alcançada por alguns Estados em desenvolvimento. A ascensão desses atores se dá em diversos níveis e setores, mas chama atenção a crescente participação dos mesmos nos fluxos econômicos internacionais, sobretudo no que tange ao seu crescimento econômico e sua capacidade de resposta à crise que atingiu o centro capitalista mundial no final da década de 2000.

As dificuldades de apreensão teórica desses fenômenos, de natureza diversa dos modelos de análise positivistas clássicos, são constantemente expostas. O "estadocentrismo" - manter o Estado como unidade de análise principal - e a "anarcofilia" - entender o sistema internacional como composto por unidades iguais - são tendências analíticas recorrentes que contaminam o entendimento de objetos inseridos em um contexto no qual o que prevalece empiricamente é a hierarquia entre os Estados (STEPHEN, 2014; ROBINSON, 2015). Tais descrições das relações internacionais se infiltraram na discussão de "potências médias" desde o começo das análises do fenômeno. Assim, essas transposições de elementos de teorias mainstream geraram implicações problemáticas e pouco adequadas às particularidades do objeto. 
A investigação teórica acerca das "potências emergentes" na academia de relações internacionais se estabeleceu a partir de diferentes abordagens no pós-guerra. O modelo funcional, a abordagem estrutural-sistêmica, a abordagem “intermediária” (de Robert Keohane) e o modelo behaviorista buscavam explicações acerca da forma como Estados industrializados não centrais se posicionavam no sistema e como o influenciavam. Tais abordagens se alternavam entre o foco na agência dos atores ou na determinação da distribuição de poder existente a partir da estrutura do sistema (HUELSZ, 2009, p. 30). O surgimento de cada interpretação está ligado a um contexto específico do campo e das relações internacionais. A cientificidade existente à época, seus aspectos disciplinares, modelavam as perspectivas analíticas mais recorrentes no momento para sua aplicação aos casos estudados.

Tais teorias, já em seu contexto, apresentaram deficiências para entender os Estados em emergência a partir da década de 1980. Uma crítica fundamental a tais abordagens é a ênfase artificial que as mesmas sustentam com relação à separação entre estrutura e agência. Outra crítica sustentava que a limitação de entender o poder somente em termos materiais ou ideacionais é insuficiente para compreender o papel das "novas” potências médias ou dos "novos" emergentes (HUELSZ, 2009, p. 27). Restringir sua relevância a assuntos secundários em relação ao núcleo duro da política internacional ou ampliá-la, a ponto de considerar tais nações como potenciais transformadoras da ordem, propositivas de um novo modelo de organização social, é tanto subestimar quanto superestimar suas características atuais. Os trabalhos subsequentes que trataram do conceito tentaram incorporar críticas dessa natureza, aproximando o conceito à realidade desses Estados não localizados no centro da comunidade ocidental.

É possível identificar alguns autores a partir da década de 1990 que incorporam em suas análises a diferenciação do contexto e dos atores em si para entender sua emergência fora do padrão de desenvolvimento industrializado. Contudo, algumas limitações persistiram, uma vez que os "novos emergentes" foram classificados segundo categorizações binárias tradicionais, pertencentes aos “desenvolvidos” ou “em desenvolvimento”, a depender do seu nível de desenvolvimento econômico (HUELSZ, 2009). A identificação desses padrões de enquadramento de casos em conceitos estabelecidos com outros propósitos teóricos gera inconsistências científicas, na medida em que traz ao conceito original elementos que poderiam ser mais bem acomodados em uma discussão qualitativamente diferenciada. 
Consideramos que os descaminhos do desenvolvimento teórico do conceito de "potências médias" - até as atuais perspectivas - ocorreram por conta da demasiada extensão de tal conceito, com objetivo de adequar diversos casos que compartilhariam alguns de seus atributos (HUELSZ, 2009). Há uma recorrente absorção nas relações internacionais dos conceitos baseados em objetos gerados por categorias referentes à realidade dos Estados do centro para analisar casos fora de seu contexto civilizacional específico. A limitação nesse tema tem um caráter (1) ontológico e (2) epistemológico. Em relação ao primeiro ponto, as unidades a que hoje nos referimos como "potências emergentes” (Brasil, China, Índia, África do Sul, Turquia, Arábia Saudita, dentre outros) possuem uma formação social interna diferenciada de uma economia capitalista e liberal, e que são transformadas por processos externos às suas fronteiras nacionais. Ademais, descolá-las de seu contexto de emergência específico, que delimita as possiblidades de ação dentro do modelo econômico vigente, nos impede de compreender seus limites de inserção e sua margem de contestação ou adesão ao sistema. Em segundo lugar, o debate sobre o papel e a influência internacionais desempenhados pelas "potências médias emergentes” é um típico problema teórico interdisciplinar e multinível muito caro à disciplina de relações internacionais.

A partir desse quadro, pontuamos alguns aspectos passíveis de problematização. A discussão não se contém em fronteiras teóricas bem definidas, uma vez que os padrões e indicadores para mensurar a influência de um Estado no sistema não são compartilhados nem mesmo por teóricos de uma mesma corrente interpretativa. Assumindo o contexto histórico atual como diverso daquele em que emergem as contribuições teóricas sobre as "potências médias", é imperativo compreendê-lo para identificar o potencial de emergência dos Estados na fase financeirizada do capitalismo. A própria configuração das unidades se diferencia frente ao contexto em que se começa as discussões sobre o tema. Logo, entender como as forças sociais internas de cada Estado respondem aos processos internacionais é também essencial.

O objetivo do trabalho é compreender, a partir das contribuições das abordagens baseadas na economia política internacional, os possíveis desdobramentos geopolíticos, econômicos e institucionais da ascensão das denominadas "potências emergentes" no sistema internacional contemporâneo. Esse trabalho avança na sistematização de alguns elementos teóricos que são capazes de apreender tendências empíricas para mapear os caminhos da caracterização de um Estado entendido como emergente no sistema. Só a partir de uma construção analítica assim é possível formar um quadro holístico do fenômeno. 
Algumas considerações terminológicas devem ser esclarecidas nesse momento para evitar entendimentos equivocados de termos recorrentes na literatura sobre o tema. Optamos por utilizar, como referência aos termos "potências médias", "potências emergentes", "potências médias emergentes", o termo Estados emergentes $^{2}$. Sobre a natureza do fenômeno, e apropriando-se da constatação para essa proposta de trabalho, "qualquer tentativa de se definir e especificar a identidade dos poderes emergentes poderia facilmente se tornar esotérica, idiossincrática particularmente inútil para o tema central sob análise nesse artigo"3 (THAKUR, 2014, p. 1791). Ainda, sobre o uso dos termos "Sul Global" e "Norte Global”: nos referimos não somente à divisão política comumente reconhecida entre economias avançadas e aquelas em outros níveis de desenvolvimento; optamos por considerar os conceitos de forma ampliada, que levam em conta as diversas hierarquizações geopolíticas de poder internacional ${ }^{4}$. Considera-se mais produtivo apresentar algumas possibilidades interpretativas sobre o fenômeno que de fato apontem para a amplitude de aspectos que o mesmo abarca. Ao tentarmos demonstrar suas limitações, não pretendemos restringir outras potenciais argumentações, mas nos posicionarmos no debate.

Prosseguiremos com a discussão a partir de três momentos. Dada a amplitude do fenômeno, apresentamos algumas problematizações acerca dos processos que envolvem a emergência dos Estados na contemporaneidade, o que demonstra como se configuram como objeto de análise para o entendimento do ambiente internacional. Na sequência, levantamos contribuições de autores da economia política internacional (EPI) que trabalham sobre os Estados emergentes e que dialogam com a configuração do sistema atual com os processos internos às unidades. A partir dessa discussão, elencamos alguns pontos sobre o quanto

2 Por "potência” entendemos o ator com um poder/papel potencial ainda não realizado de suas capacidades no sistema internacional - o que, utilizando o termo Estado, não implicaria comprometimento dessa análise. A classificação "média” situa o ator em um estrato da política internacional próximo à classificação da literatura tradicional, geralmente em arenas da chamada baixa política; por "emergente” classificamos aquele ator que passa a exercer um peso maior na política internacional em relação ao seu momento anterior em decorrência do incremento de seu poder em relação ao sistema como um todo.

3 Any attempt to define and specify the identity of "emerging powers" could quickly become esoteric, idiosyncratic and not particularly helpful for the central issue under analysis in this article.

4 A discussão sobre Sul Global e Norte Global, ainda que agrupe os Estados de acordo com posição geográfica que, em alguma medida, coincidira com seu nível de industrialização, deve ser vista de forma ampliada. Contemporaneamente, tal divisão ajuda a informar hierarquias sobrepostas entre várias dimensões da categoria de poder - de aspectos materiais a subjetivos. Ademais, vale ressaltar no momento da aplicação: 1) qual tipo de emergência é utilizado para classificação dos países; 2) levar em conta a heterogeneidade dos Estados localizados nos hemisférios Sul ou Norte, evitando uma classificação automática. 
podemos considerar os ditos Estados emergentes como reais ou potenciais transformadores da ordem internacional, tanto no que diz respeito aos aspectos materiais quanto aos ideacionais.

\section{Potencial analítico do fenômeno}

A dificuldade de teorização do fenômeno dos Estados emergentes decorre da multiaspectualidade dos elementos e dilemas recentes que os circundam. O processo de ascendência desses atores se inicia no último quartel do século XX, mas chama atenção sua discussão mais sistematizada e intensificada a partir do início do século XXI. Desde então, pululam publicações sobre as diversas dimensões do fenômeno, seja sobre o fortalecimento do Estado frente às crises econômicas, seja sobre a transnacionalização de suas economias; seu papel em organizações internacionais e outros fóruns multilaterais; e os dilemas sociais internos enfrentados por Estados que são "potências regionais"5. Nos últimos anos, edições especiais de periódicos acadêmicos da área de relações internacionais se dedicaram à forma como tais Estados emergentes do Sul Global se comportam frente ao consenso de Washington (BAN; BLYTH, 2013) e como se encaixam em um contexto de transformações da governança global (GRAY; MURPHY, 2013). $\mathrm{O}$ grau de distanciamento frente à ordem vigente vem sendo objeto caro às discussões sobre os Estados emergentes, sobretudo quando consideramos aqueles que buscam uma autonomia político-econômica no Sul Global.

A ideia de Sul Global como espaço político que concentra Estados que buscam sua autodeterminação data das pós-independências na segunda metade do século XX. Politicamente, a Conferência de Bandung, de 1955, e o movimento dos Estados não alinhados da década de 1960 forneceram elementos para um esforço intelectual que culminaria em proposições objetivas para uma ordem global posterior mais equânime. As ambições existentes no projeto da nova ordem econômica internacional da década de 1970 tinham o intuito de diminuir as disparidades econômicas internacionais entre os Estados centrais e os Estados periféricos, o que proporcionaria aos países em desenvolvimento a condução de seu próprio desenvolvimento socioeconômico (GOLUB, 2013). Os impasses enfrentados pelos Estados da periferia do capitalismo, em decorrência dos choques

5 O termo "potência regional" refere-se ao Estado que tem a capacidade de exercer influência sobre os outros atores que se localizam no seu espaço geográfico próximo. 
do petróleo nos anos de 1970, foram sentidos especialmente na América Latina e na Ásia com as crises da dívida e as crises monetárias das décadas de 1980 e 1990, respectivamente. O impacto econômico sofrido por esses países diluiu o esforço das décadas anteriores em construir uma força conjunta de governança global a partir de "baixo". Entretanto, a subsequente não transformação da ordem, a permanência da hegemonia estadunidense e da estrutura hierárquica do sistema não podem ser vistas como a falência do Sul Global. Tais momentos da história inauguram alguns dos aspectos observáveis nas reivindicações dos emergentes da contemporaneidade pela busca de uma maior equidade na governança global.

O século XXI se tornou palco de transformações político-econômicas globais que abriram canais para uma redefinição de papéis entre os Estados no ordenamento de tal forma que afetou a distribuição de poderes dentro do Sistema Internacional. O que difere a natureza dos demandantes atuais e os movimentos terceiro-mundistas das décadas anteriores é o intenso engajamento internacional, consequente da grande dimensão econômica que os primeiros alcançaram sem se distanciar da ordem hegemônica (GRAY; MURPHY, 2013). Os avanços de uma descentralização do poder na economia política internacional global não estão necessariamente relacionados a uma transformação dos princípios hegemônicos do sistema. A dizer, a participação de alguns Estados emergentes do Sul Global, que se distanciam cada vez mais da maioria dos outros países em desenvolvimento, não indica uma democratização do sistema no sentido de inclusão de todos os emergentes na governança global. A identificação do posicionamento dos Estados emergentes em várias arenas políticas e econômicas é essencial para desvelar se os países que mais vêm se destacando representam ou não os interesses daqueles pouco vocalizados internacionalmente.

Temas antes tratados como secundários para o dimensionamento do poder na agenda global são fundamentais para dimensionar o potencial dos Estados emergentes como transformadores da ordem. A reivindicação por parte de países como Brasil, China, Rússia e Arábia Saudita por uma ordem mais participativa, "mais justa”, não é reflexo das relações sociais que esses mantêm internamente. "Em resumo, muitos dos países mais desiguais do mundo demandam equidade nos fóruns globais" (CHANDHOKE, 2013, p. 311). Um dos aspectos passíveis de esvaziamento em tal contexto é o tratamento da questão da pobreza. Apropriado por organizações multilaterais de desenvolvimento, o reposicionamento do discurso sobre a erradicação da pobreza é tratado como tema de reforma e não de mudança

6 In sum, some of the most unequal countries in the world demand equality in global forums. 
estrutural na ordem (VAN DER WESTHUIZEN, 2012). A pobreza é um elemento característico dos países em desenvolvimento - o que inclui aqueles aqui tratados como emergentes. Para além de uma preocupação moral com o bem-estar social, o discurso da pobreza pode incorrer na armadilha de uma falsa canalização das demandas dos emergentes, uma vez que é um aspecto historicamente vinculado a instituições multilaterais. Qualificar quais são os temas e as reivindicações realmente genuínos e que aproximam os Estados emergentes de maior destaque no sistema internacional contemporâneo delimita as possibilidades analíticas de compreender as transformações em curso.

As tentativas de compreender o fenômeno estimularam agrupamentos de países a partir de alguns atributos supostamente compartilhados. Um relatório, com o objetivo de gerar novos destinos de investimento, publicado em 2001 (SACHS, 2001), provocou uma inflexão na forma de se entender os mercados de investimento, os ditos "mercados emergentes". O termo BRICs (Brasil, Rússia, Índia e China) desencadeou um processo em que o conhecimento produzido sobre o campo econômico gerou implicações políticas reais. Além de um aumento de transações econômicas, tais como investimentos diretos externos, politicamente isso também se evidencia, a partir do momento em que os países passaram a se reunir em cúpulas até a formalização de um banco de investimentos em 2015. Ainda que tal acrônimo não seja a razão de sua crescente influência internacional, a criação catalisou a emergência de "circuito cultural de capital" distinto (WANSLEBEN, 2013). A partir dos BRICs, uma série de agrupamentos reúne Estados sugerindo mercados e sociedades em "emergência".

Cada tentativa de sistematizar uma identidade diferente aos Estados agrupados gera novas potencialidades analíticas, mas pode incorrer no erro da extensão do conceito de “emergentes” a esferas impróprias. Agrupar Índia, Brasil e África do Sul (chamados IBSA) para uma estratégia mais proporcional entre as unidades parece coerente, até quando situamos os atores em seus respectivos contextos geopolíticos. Incorporar a China a esse grupo (transformando IBSA em BASIC), com o intuito de representar a periferia ascendente do capitalismo, levanta questões sobre a legitimidade de representação do grupo. Como será discutido adiante, o acrônimo BRICs (ou BRICS7 ) já agrega uma disparidade significativa entre seus membros.

\footnotetext{
7 A incorporação da África do Sul se dá em 2009, transformando o acrônimo em BRICS. A despeito disso, alguns trabalhos ainda mantém o grupo sem África do Sul por questões metodológicas referentes aos atributos utilizados para agrupá-los. Quando a referência não incorporar a África do Sul como integrante do grupo, manteremos o acrônimo como BRICs; e, quando incorporada, BRICS.
} 
Compreender os parâmetros e as categorizações são fundamentais para evitar o esvaziamento da discussão. As implicações políticas dessas tensões analíticas são importantes, uma vez que a transformação do conhecimento econômico pode alterar realidades materiais (WANSLEBEN, 2013).

Definir com clareza quais são os aspectos que indicariam um "Estado emergente" é uma das carências na literatura. Para os propósitos deste trabalho, consideramos que o termo

Emergência significa grupos de auto-organização que correspondem estrategicamente à economia política global na qual estão entrelaçados. Eles são organicamente adaptados à dinâmica do sistema. Os microelementos contribuem para a constituição de macrocomportamentos em um mundo crescentemente policêntrico. A política da emergência é parte crucial deste fenômeno. Vale enfatizar que a rubrica "mercados emergentes" omite a política e que a "poderes emergentes" ou "poderes em ascensão" negam a economia. Superar tal separação, com a implícita primazia tanto da economia quanto da política, parece adequado. ${ }^{8}$ (MITTELMAN, 2013, p. 26)

As interações entre o Estado, o mercado e a sociedade são fundamentais para compreender os limites e as possiblidades de atuação desses atores na governança global. Uma investigação acerca desse fenômeno envolve diferentes níveis de análise organicamente interligados sem uma separação entre fenômenos políticos e econômicos.

Os elementos ontológicos do fenômeno contemporâneo dos Estados emergentes perpassam "processos globalizantes, corporações transnacionais, regiões, Estados, organizações subnacionais e internacionais, cidades e estruturas sociais"9 (MITTELMAN, 2013). É nítida a dificuldade de compreender de forma coesa as diferentes possibilidades e modelos que serão introduzidos a partir desses processos que, ainda, se configuram como desordenados e espontâneos. Nisso, podemos incluir as continuidades e descontinuidades dos processos de integração regional e inter-regional; os caminhos alcançados por visões

8 Emergence denotes clusters of self-organisation that are responding strategically to the global political economy in which they are enmeshed. They are adapting organically to a dynamic system. The micro-elements contribute to constituting macro-behaviour in an increasingly polycentric world. The politics of emergence is a crucial part of this phenomenon. It is worth emphasizing that the rubric "emerging markets" omits the politics and that the header "emerging powers" or "rising powers" deflects the economics. Overcoming this separation, with its implicit primacy of either economics or politics, seems referable.

9 Globalising processes, transnational corporations, regions, states, international and subnational organizations, cities and social structures. 
emancipatórias dos emergentes; e o redimensionamento de forças políticas no plano internacional.

A transdisciplinaridade se impõe sobre o problema, sobretudo, ao considerarmos que suas bases se fundamentam e dependem de modificações no capitalismo global contemporâneo. Identificar os princípios do funcionamento do capitalismo, em sua fase financeira, e quais as possibilidades nos fluxos possíveis entre os Estados (seja no setor comercial, de investimento e/ou financeiro), é um ponto chave na discussão. Não é possível compreender o posicionamento das unidades do sistema sem o panorama geral sobre o qual as relações sociais e econômicas internacionais são estabelecidas. Apenas com uma abordagem capaz de vincular tais aspectos é possível avançar na compreensão das determinações.

\section{Contribuições da Economia Política Internacional}

Frente à necessidade de um diálogo mais coerente entre objeto/fenômeno e teoria, as abordagens críticas a partir da economia política internacional fornecem elementos interessantes. A validade de uma abordagem materialista histórica reside na capacidade de identificar a natureza da mudança do capitalismo, que incide diretamente sobre as relações nacionais entre Estado e sociedade. Em termos de avanço frente ao que já foi anteriormente proposto como opções teóricas, "usar um entendimento crítico de estrutura e agência ajuda a melhorar a forma de identificar e entender diferentes formas de poder"10 (HUELSZ, 2009, p. 64). Da mesma maneira, evita a separação instrumental entre questões econômicas e políticas, que são partes codeterminantes de um mesmo modo de produção social. A perspectiva da economia política internacional é capaz de incorporar elementos e processos que não se restringem aos limites territorialistas das abordagens mainstream.

As funções desempenhadas na dimensão transnacional das relações socioeconômicas transcendem o "estadocentrismo" clássico das teorias políticas e ressignificam a forma de inserção dos emergentes na economia global. A estrutura do capitalismo contemporâneo pode ser caracterizada como "híbrida": ao mesmo tempo em que se observa uma crescente integração transfronteiriça, acompanha-se uma erosão dos princípios liberais da governança global hegemônica

10 Using a critical understanding of structure and agency further helps to better identify and understand different forms of power. 
(STEPHEN, 2014). O Estado se diferencia historicamente a partir de seu modelo de regulação de mercado e o nível de transnacionalização de seus circuitos econômicos. Considerando-se que as alterações das forças sociais internas ocorrem em decorrência do processo de estruturação da econômica global (dado o nível de integração econômica), os interesses nacionais são moldados a partir do resultado dessas interações (STEPHEN, 2014; ROBINSON, 2010). O Estado, para os países emergentes, vive em função da dialética, que é organizar sua estrutura interna de forma que as elites domésticas possam se integrar transnacionalmente aos fluxos globais da economia.

Uma das especificidades dos Estados em desenvolvimento é a relação estabelecida por suas elites transnacionais em ascensão e as respectivas estruturas governamentais postas a seu serviço. O “capital transnacional” é a atual fração hegemônica do capitalismo constituída por elites ${ }^{11}$ internacionalizadas de diversas origens nacionais, interligadas por cadeias de valor produtivas ou financeiras (ROBINSON, 2010). Em países em desenvolvimento, tal processo ganha características diferenciadas.

A formação das classes transnacionais nos países em desenvolvimento é a maior dimensão da globalização capitalista. Na medida em que o capitalismo global penetra em novas esferas e as sujeitam com sua lógica de acumulação transnacional, as classes pré-globalizadas, tais como camponeses e artesãos, tendem a desaparecer, substituídos por novos grupos de classes subordinados e dominantes ligados à economia global. Geralmente, temos visto isso em países em desenvolvimento: a Ascenção de novos grupos dominantes e frações de classe ligadas à econômica global; a diminuição da mobilidade - ou proletarização - das antigas classes médias e estratos profissionais e a ascensão de novas classes trabalhadores rurais e urbanas ligadas aos processos de produção transnacional; a própria classe trabalhadora se tornou flexibilizada e informalizada; o aparecimento de uma massa expandida desde supranumerários ou marginalizados. ${ }^{12}$ (ROBINSON, 2010, p. 7)

11 Neste texto, partimos da definição de elite como uma parcela socioeconomicamente e politicamente dominante. Nos países em desenvolvimento, geralmente estão associados à administração do sistema político do Estado, ainda que não sejam capitalistas detentores dos meios de produção de valor. Não obstante, determinantes são suas funções ou colaborações para a reprodução do capital (ROBINSON, 2010, p. 3).

12 Transnational class formation in the developing countries is a major dimension of capitalist globalization. As global capitalism penetrates new spheres and subjects them to the logic of transnational accumulation, pre-globalization classes such as peasantries and artisans tend to disappear, replaced by new dominant and subordinate class groups linked to the global economy. We have generally seen in developing countries: the rise of new dominant groups and capitalist fractions tied to the global economy; the downward mobility - or proletarianization - of older middle classes and professional strata and the rise of new middle and professional 
A decorrente transformação na natureza clássica do Estado - espaço territorial onde se concentra o poder no monopólio da força - impõe desafios sobre problemas outrora reconhecidos como objetos do âmbito doméstico. Como projetar políticas para o desenvolvimento nacional quando os processos não são mais gerenciados no interior das fronteiras nacionais e são, ao mesmo tempo, dinamizados pelo nível de transnacionalização definida a partir da função exercida pelo Estado em sua inserção internacional?

Independente do grau de integração do Estado nas redes globais da economia mundializada, compreender o fenômeno de Estados emergentes exige compreender o comportamento das elites ou da classe capitalista transnacional. A plataforma política internacional de países, como, por exemplo, os membros do BRICS, é direcionada para uma associação mais profunda ao capitalismo por meio do capital transnacional. A integração na economia global vem sendo o caminho encontrado por países emergentes para incrementar seu poder econômico e sua influência política (ROBINSON, 2015) A clivagem Norte-Sul anterior é hoje melhor entendida em termos de uma divisão social transnacional em detrimento de uma divisão geopolítica. Talvez seja possível assinalar mais proximidades entre Estados do Norte e do Sul Global quando percebidos em uma perspectiva histórica mais ampla.

Por essa dificuldade em estabelecer os limites de uma "cooperação" entre esses Estados na concertação da ordem capitalista global, é essencial compreender os mecanismos que estabilizam a ordem e quais são os Estados que comportam as elites dirigentes determinantes para manter a ordem capitalista global. Assim, o questionamento do papel dos Estados Unidos como tutor da ordem acompanha os debates sobre a ascensão dos emergentes do Sul Global. Contudo, é relativizado o declínio dos Estados Unidos como centro de referência econômica mundial, sobretudo no que tange aos processos de estabilização monetária (STARRS, 2014). O grau de interdependência econômica hoje indicada pelo compartilhamento de ativos e títulos de dívidas, por exemplo, aparenta uma fuga analítica para ampliar a relevância dos BRIC, sobretudo quando sobressaltamos o montante que a China concentra da dívida pública estadunidense (VANAIK, 2013). As instituições de Bretton Woods de fato foram se colapsando ao longo dos anos, mas foram essenciais para a construção de uma hegemonia financeira sólida ainda desempenhada pelos Estados Unidos.

strata; proletarianization of peasants and artisans and the rise of new urban and rural working classes linked to transnational production processes; the working class itself become flexibilized and informalized; the appearance of an expanding mass of supernumeraries or marginalized. 
Essa hegemonia “autossustentável” não deve ser compreendida como um fenômeno pós-Guerra Fria. As condições estruturais existentes no momento do estouro da crise de 2008 são as mesmas da década de 1970. Há cerca de quase meio século, a desregulamentação do setor financeiro e o esvaziamento da estrutura intervencionista estatal aprofundou o caráter desigual do capitalismo (VANAIK, 2013). As crises econômicas são analiticamente ilustrativas para entender a dimensão da distribuição do poder no capitalismo atual. Momentos de turbulência prologada, como aqueles iniciados em 2008, são apenas episódios recorrentes em uma estrutura onde a instabilidade é o princípio ordenador. As particularidades de cada crise devem ser compreendidas a partir de cada momento histórico específico, quando a configuração do jogo de forças envolvidas redefine as caraterísticas geopolítico-econômicas. Na América Latina, durante a década de 1980, e na Ásia, na década de 1990, sobressaltaram-se as fragilidades da periferia com as crises da dívida para financiamento das contas públicas voltadas ao desenvolvimento industrial. De forma diversa, os finais da década de 2010 apontaram para a vulnerabilidade dos antes "credores" do sistema.

A fragilização das unidades centrais do sistema internacional abre espaço para os ganhos dos emergentes. Os débitos nas contas públicas são relativamente maiores nas economias ditas avançadas em relação aos Estados em desenvolvimento melhor estruturados macroeconomicamente. Contudo, o fato dos débitos estarem todos condicionados ao dólar estadunidense demonstra a capacidade de retroalimentação do sistema. Os choques externos ainda determinam com maior intensidade a vulnerabilidade daqueles Estados endividados pela moeda padrão internacional. Esse "privilégio" do hegêmona garante sua posição no sistema econômico internacional (ANTONIADES, 2013). A legitimidade da ordem dependerá da forma como se proporá a regulamentação dos fluxos financeiros e da dívida. Os Estados emergentes podem desempenhar um papel fundamental nessa nova configuração da governança global financeirizada.

E tal papel dependerá da forma como os Estados emergentes irão lidar com as contradições entre a penetração das finanças internacionais e o controle das relações sociais nacionais. Existem maneiras pelas quais os governos utilizam intencionalmente medidas monetárias ou financeiras para atingir seus propósitos de política externa. Compreender os propósitos dos ajustes econômicos realizados pelos Estados emergentes indica padrões de alinhamento ou não aos princípios regulatórios compartilhados internacionalmente (ARMIJO; KATADA, 2015; 
KATARIA, 2013) ${ }^{13}$. O uso intencional dessas estratégias tem como intuito principal reverter uma situação desfavorável ou mesmo transformar pressões financeiras em situações positivas para a economia. Dependendo do teor defensivo ou ofensivo da ampliação do crédito, da promoção de investimento ou da alavancagem de moedas, comportamentos unilaterais ou coordenados entre os Estados emergentes podem ser traduzidos em questionamentos na ordem. A continuidade de tais ações será traduzida em alterações na governança, o que inclui uma ressignificação dos princípios ordenadores que são legitimados por instituições multilaterais.

O papel das organizações internacionais é determinante na legitimação da natureza da governança global em andamento. Uma das características mais sistematizadas na literatura é sua função de representar os interesses do concerto de forças de um determinado momento histórico, servindo de instrumento dos Estados. Contudo, as contradições existentes no capitalismo global não são comportadas no interesse nacional dos Estados dominantes. As instituições internacionais são o locus onde são coordenadas essas contradições, conferindo-lhes uma relativa autonomia frente a tais interesses. Isso não significa que os princípios da ordem não coincidam com os Estados centrais, mas que algumas das demandas dos Estados emergentes são necessariamente incorporadas com o intuito de cooptar os contestadores da ordem. Não é sem propósito que a coordenação de ações entre o Banco Mundial e o Fundo Monetário Internacional incitam que

os países em desenvolvimento assumem a "direito" de políticas relevantes, “aceitando a responsabilidade pelo seu próprio desenvolvimento, e [adotando] estratégias vinculadas às circunstancias de seus países e envolvem uma ampla participação”, e os países industriais abrem seus mercados, elevam a ajuda e promovem o perdão da dívida [...] Isso prevê um comprometimento comum às “políticas certas” em promover a acumulação no nível doméstico, cooperar no nível global com o intuito de aumentar a estabilidade da economia mundial como um todo, e concertar esforços dentro e ente países individuais para assegurar a legitimidade de pacotes de políticas e iniciativas globais relacionadas. ${ }^{14}$ (CAMMARCK, 2003, p. 53)

13 Essa referência utiliza o financial statecraft como elemento para complementar a análise realista neoclássica aplicada para compreensão de como o uso intencional dessas medidas evitam uma perda de influência no sistema econômico (ARMIJO, KATADA, 2015).

14 The developing countries to assume "ownership" of the relevant policies, "accepting responsibility for their own development, and [adopting] strategies tailored to country circumstances and involving broad-based participation”, and upon the industrial countries to open their markets, increase aid, and provide debt relief [...] It envisaged a common commitment to "the right policies" to promote accumulation at domestic level, co-operation at global level in order to improve the stability of the world economy as a whole, and concerted efforts within and across individual countries to secure legitimacy for the policy packages and global initiatives concerned. 
Tal "adaptabilidade” da ordem é a maneira de controlar as contradições sistêmicas externalizadas nas disputas a partir do nível nacional. O quadro que se apresenta não contém elementos suficientes para configurar um declínio da fase neoliberal capitalista, mas somente possibilita o entendimento da forma como o sistema é organizado para absorver as crises cíclicas e os atores contestadores.

As evidências podem indicar uma transformação da ordem; entretanto, no sentido de transição de hegemonia, não há consistência sequer para demonstrar a superação da crise - entendendo-a como parte indissociável das transformações e adequações do funcionamento do sistema capitalista. Em termos teóricos, há um limite na compreensão do papel dos Estados emergentes quando agrupados. Entendê-los como um ator coletivo - mesmo que seus propósitos residam sobre a estabilização do sistema e o não questionamento da hegemonia - envolve um compartilhamento de interesses e valores que dificilmente se verifica nos casos apresentados. Esses limites se evidenciam ainda mais quando minuciados alguns indicadores específicos sobre setores econômicos entre os países do Norte e do Sul, e entre os próprios Estados emergentes.

\section{Limites e potencialidades de transformação da ordem}

A despeito de muitos avanços nas discussões acerca do fenômeno dos Estados emergentes, algumas questões permanecem em aberto. O nível de coesão pode ser definido a a partir dos limites de competitividade quando confrontados diretamente em setores econômicos determinantes para suas respectivas receitas. As relações entre os próprios emergentes são condicionadas às relações que possuem individualmente com os Estados centrais. Logo, as dificuldades de coordenação são complexificadas pelas posturas bilaterais já estabelecidas entre o Norte e o Sul Global. Existem elementos consistentes o suficiente para indicar que o declínio do modelo ocidental é inevitável e a transformação dos Estados emergentes, rumo ao patamar de "potência”, como inexorável?

De início, há evidências de uma diminuição do ritmo de crescimento dos indicadores econômicos dos Estados emergentes. Os setores econômicos mais relacionados e dependentes dos fluxos de capitais estrangeiros vêm sofrendo uma queda, em decorrência de um ciclo econômico positivo em torno dos preços das commodities. Seu recuo aconteceu com o advento da crise recente, demonstrando a contínua dependência sobre o setor primário exportador (STARRS, 2014). Ademais, 
a dominância dos Estados Unidos sobre alguns setores econômicos se manteve ou teve um acréscimo em termos relativos quanto a seu principal concorrente (STARRS, 2014). O crescimento verificado nos períodos anteriores à crise de 2008 não deve ser atribuído a um declínio dos Estados Unidos sem que esse seja devidamente qualificado. Sendo assim, as melhoras (que foram significativas) nos indicadores econômicos de países, como, por exemplo, os membros do BRIC, não alcançaram um patamar suficiente para desafiar a predominância estadunidense no direcionamento da agenda econômica.

Os padrões de crescimento elevado dos Estados emergentes corresponderam a um contexto favorável de estabilidade macroeconômica internacional e a um redirecionamento de atenção dos Estados centrais a suas realidades nacionais. Ademais, os BRICS enfrentam problemas internos de déficits estruturais, instabilidades políticas, insegurança social, dilemas sobre a capacidade de extensão interna do consumo (POORSAFAR, 2013). Entretanto, simbolicamente, suas implicações políticas têm repercussões importantes na redefiniçao dos parâmetros da governança global e isso será posteriormente retomado. Talvez sejam esses os elementos - com impactos degradantes para suas respectivas sociedades - que aproximam as unidades do acrônimo BRICS.

As ditas convergências em assuntos globais, que manteriam a unidades do grupo enquanto "emergentes", se baseia apenas em um nível genérico. Assuntos como mudanças climáticas, negociações sobre fluxos de comércio e aqueles ligados a algum tipo de intervenção militar por parte das potências centrais já são descompassados, dependendo do fórum em que se encontram. A China não só se distancia de outros países em desenvolvimento, como dos integrantes do G7715, em termos econômicos, como também destoa dos acrônimos dos quais faz parte. É em si o Estado impulsionador dos indicadores elevados nas demonstrações da crescente relevância dos emergentes. Sobre a China, podemos dizer que: (a) que tanto suas relações com a Rússia quanto com a Índia podem causar tensões internas à região asiática; (b) é um forte competidor frente ao potencial brasileiro de exportação; e (c) que levanta dúvidas "morais" sobre sua incursão desenfreada na África para escoar sua necessidade de crescimento econômico (PANT, 2013). Ou seja, a despeito do desejo de mudança do ordenamento econômico internacional que viabilizaria uma inserção mais vantajosa dos Estados

15 O G77 é um grupo de países em desenvolvimento institucionalizado dentro do âmbito da ONU, cujos objetivos centrais se resumem a uma coordenação de interesses econômicos e à promoção de uma cooperação entre Estados do Sul Global. 
emergentes, como deveria se configurar essa democratização sistêmica ainda é um assunto nebuloso.

Parte da dificuldade de consenso político mais claro entre os BRICs pode ser associada à forma como lidam com as convenções internacionais. A dificuldade em compreender até que ponto o Consenso de Washington é contestado pelos emergentes reside na adesão aos princípios macroeconômicos pré-determinados e às condicionalidades aceitas para obtenção de recursos internacionais. O Consenso de Washington não foi só um conjunto de proposições para estabilização da econômica; as recomendações disseminam uma cultura político-econômica neoliberal financista que condensa a natureza da hegemonia da fase contemporânea do capitalismo (BAN; BLYTH, 2013).

O Consenso de Washington não perdeu sua relevância como modelo estruturador macroeconômico, nem como paradigma político. O FMI, grande promulgador das ideias do Consenso, atingiu um grau de autonomia que lhe impõe a necessidade de aplicar as mesmas normas restritivas àqueles que outrora foram seus legitimadores, e que hoje sofrem com danos do sistema inflacionado - a situação europeia é representativa disso (FOURCADE, 2013). As estratégias dos BRICS não correspondem às prescrições mais liberais do Consenso de Washington; a intervenção estatal figura como o princípio contestador de Estados emergentes como o Brasil, a Rússia e a China. Entretanto, é equivocado considerar que o ordenamento internacional rumo à estabilidade macroeconômica como premissa para o desenvolvimento já não tenha sido introjetada à racionalidade dos Estados emergentes.

Os resultados econômicos positivos que carregam a alcunha de "emergentes" estão diretamente relacionados com medidas dessa natureza. Como consequência, viabilizaram o redirecionamento da atenção internacional para essas economias como novos destinos de investimento. Mas o que se tem é uma economia global definida em termos de desigualdade, construída historicamente a partir das diferenças de desenvolvimento tecnológico e dos ganhos resultantes da expansão comercial. Não existe tendência automática para uma "convergência” entre os Estados emergentes e as economias avançadas quando comparados os níveis de desenvolvimento dos mercados tecnológico, financeiro e comercial (SAAD-FILHO, 2014). O nível de crescimento econômico se deu de forma diferenciada entre os países em desenvolvimento. Os dois países com desempenhos destoantes foram a China e a Índia. Esse é um dos motivos pelo qual se elaboram proposições em que esses dois Estados emergentes seriam parte, ao lado de Estados Unidos, União 
Europeia e Rússia, de um "quinteto" hegemônico. Os problemas de interpretações como essas são observáveis quando se considera a incompatibilidade ideológicapolítica entre os atores, sobretudo no peso desproporcional que ainda reside nos Estados Unidos (VANAIK, 2013).

As formações entre Estados economicamente mais semelhantes podem ser mais prolíficas para interpretar os limites de ascensão dos Estados em desenvolvimento. Em razão da desproporcionalidade com a China - que dá mais peso ao BRICS ou ao BASIC - o IBAS foi iniciado em 2003 como contraposição às rodadas de negociações comerciais desfavoráveis ao Sul Global na Organização Mundial do Comércio. Essa é uma "atividade multilateral [que] pode de fato ter um potencial em deslegitimar a ordem mundial em curso. As variáveis são as condições globais objetivas e as concomitantes posições das elites"16 (TAYLOR, 2009, p. 47). As limitações de avanços institucionalizados emergem de várias frentes: das restrições impostas por suas instituições de cooperação regional, da sua incapacidade de se desvincular das regras econômicas internacionais e das suas tentativas estadocêntristas de lidar com processos globalizados. Ainda que haja a tendência de compreender essas coalizações em termos simbólicos, a ilusão acerca do real potencial transformador da ordem por parte de emergentes do Sul Global pode sobrevalorizar os aspectos proativos do fenômeno ao invés de elucidar seus aspectos reativos aos dilemas impostos pela necessidade de restruturação capitalista.

Em suma, "três [são os] aspectos do atual Sistema capitalista global: a contínua dominação dos EUA, a extraordinária ascensão do Resto (China em particular), e a estreita correlação entre tal ascensão e o índice de preços de matérias-primas"17 (STARRS, 2014, p. 95). O aspecto fundamental dessa caraterização é compreender que a elevação dos preços dos produtos de exportação dos países em desenvolvimento foi o motivo pelo qual a ascensão dos Estados em emergência se sustentou. Novas frentes econômicas foram abertas em decorrência da valorização financeira nesses mercados, mas seus limites esbarram em uma hegemonia estadunidense que se manteve em relação aos outros Estados no ambiente internacional. Pensar em uma concertação "contra-hegemônica” a partir de um "Consenso de Beijing” deve servir apenas como um conceito relacional para ressaltar os processos em curso, e não uma transição hegemônica inevitável (FOURCADE, 2013).

16 Multilateral activity (that) can in fact have a certain potential in de-legitimising the ongoing world order. The variable is objective global conditions and the concomitant positions of elites.

17 Three [are the] aspects of today's global capitalism system: the continued dominance of the US, the extraordinary rise of the Rest (China in particular), and the tight correlation between that rise and the raw materials price index. 
Os pontos levantados ao longo da discussão constituem parte da literatura referente ao tema proposto. Não foi nosso intuito esgotar as fontes e as perspectivas sobre o fenômeno dos Estados emergentes. Entendemos que apenas com o desenvolvimento futuro das relações entre tais atores será possível entender com clareza a dimensão da transformação sistêmica. A proposta chinesa de substituição da dependência internacional ao dólar estadunidense pode ter desdobramentos importantes na atual supremacia monetária internacional. As respostas a estes e a outros processos em curso devem ser compreendidos não apenas na realidade imediata, mas em relação aos seus determinantes anteriores e às prospecções que podem causar.

\section{Conclusões}

A compreensão do fenômeno dos Estados emergentes é uma das possiblidades interpretativas mais promissoras do campo de relações internacionais quando se pretende retratar o quadro político no sistema internacional do século XXI. Suas potencialidades analíticas provocam a necessidade de um diálogo interdisciplinar com outras ciências correlatas. Ao mesmo tempo, impele uma apreensão transdisciplinar entre os analistas internacionais que desejam enveredar por tais processos e entendimentos.

O que se chama hoje de “emergentes” difere substancialmente dos atores assim chamados nas abordagens realizadas no decorrer da segunda metade do século $\mathrm{XX}$, de onde se toma tal conceito. A discussão sobre a prevalência de afirmações terceiro-mundistas nas definições pode ser mais adequada do que as caracterizações tradicionais, que se restringiam a sociedades industriais já bem estabelecidas. Os avanços nas intepretações mais apropriadas à natureza desse fenômeno contemporâneo evitam alongamentos conceituais, cujos efeitos podem significar a perda de suas validades científicas.

As iniciativas de formação de acrônimos com o objetivo de apontar ações coordenadas entre os Estados emergentes - como os BRIC(S)s, IBSA, e BASIC facilitam a visualização dos blocos de poder que se contrapõem à ordem hegemônica neoliberal. Entretanto, cuidados mínimos são necessários quando comparamos atores com estruturas sociais internas tão díspares. A proximidade no posicionamento em relação a alguns temas globais não indica um compartilhamento irrestrito de concepções e valores. Um exemplo evidente é a diferença 
entre advogar em favor de uma "democratização do sistema internacional" e reivindicar o respeito à autodeterminação política interna, sobretudo, no que tange aos limites intervencionistas dos Estados em áreas hoje amplamente desregulamentadas e privatizadas.

As diferentes posturas dos Estados são também fruto dos seus processos individuais de crescimento e desenvolvimento. A forma como os Estados respondem aos desafios impostos pela transnacionalização financeira redefine as funções por eles despenhadas no sistema internacional e suas responsabilidades internas para a coesão social. Nesse ponto, a forma como suas elites dirigentes e suas elites integradas internacionalmente dialogam define suas probabilidades de aprimorar a própria inserção internacional.

A ordem capitalista contemporânea é marcadamente definida por processos de transnacionalização da produção de valor. Mais aguda ainda é a fluidez da formação de um capital fictício, responsável pela crescente instabilidade do sistema econômico internacional. As classes transnacionalizadas são cada vez mais "multinacionalizadas"; a cadeia de produção de valor nessa fase do capitalismo já se encrustou em diversas elites que se localizam não apenas nos países centrais, mas também nos Estados emergentes mais bem associados à dinâmica sistêmica. O nível de sensibilidade dos países é homogeneamente compartilhado, mas suas vulnerabilidades respondem a capacidades bem diferenciadas.

Questionar a existência de um hegêmona, uma ordem política unipolar dirigida por um Estado que teve perda de legitimidade política, não implica decadência inevitável do modelo capitalista que emergiu quando da ascensão de tal Estado. É fundamental atentarmos para qual o processo hoje em curso: a dificuldade de legitimação de uma hegemonia estatal talvez resida na crescente sustentação da ordem por elementos por ela autonomizados. Nesse aspecto, algumas instituições exercem papel essencial na legitimação dessa ordem fragilmente "autossustentada" - dada a recorrência de crises econômicas e de legitimação.

As organizações internacionais são capazes de agir em condescendência com os interesses dos Estados centrais, mas com forte interesse em adaptar suas estratégias político-econômicas à participação dos emergentes. A urgência da mudança de foco reside na lucidez de reconhecer que uma "nova governança global" exige uma redistribuição maior de custos e uma reconcentração de poder. A crescente atenção internacional frente às potencialidades dos mercados e dos Estados emergentes foi em si parte de um processo de ressignificação do entendimento econômico e das novas necessidades do capital internacional. 
O início deste milênio inaugura uma nova fase de ideias que foram introjetadas e posteriormente alcançaram as realidades econômicas dos Estados envolvidos.

A história recente da América Latina fornece um exemplo claro de como as ideias, no plano econômico, têm potencial transformador da realidade internacional. No período pós-II Guerra, o discurso internacional era voltado para industrialização e expansão do mercado interno. A Comissão Econômica para América Latina foi um órgão preponderante na disseminação dessas diretrizes. De caráter policy-oriented sob os auspícios da Organização das Nações Unidas, sempre teve seu respaldo. Com a crise da dívida e as medidas de austeridade impostas pelos pontos do Consenso de Washington, não apenas as práticas discursivas se voltaram para uma integração dos mercados internacionalmente, como foi assumida a orientação de políticas macroeconômicas pré-determinadas para atingir tal fim. Ligeiramente oposto ao período anterior, esse foi um dos meios de vocalização do discurso neoliberal (ROBINSON, 2010).

Os acrônimos formados nos últimos anos têm um alto potencial contestador, quando comparados ao que havia de potencial no grupo de países latino-americanos endividados que poderiam ter imposto a moratória coordenadamente em 1980. Como ressaltamos durante o artigo, identificar as especificidades históricas nesses processos é fator chave no entendimento do que pode vir a ser essa "nova governança global”. As qualificações são necessárias quando comparamos em termos absolutos e relativos o crescimento econômico real dos Estados emergentes em relação aos Estados centrais.

\section{Referências}

ANTONIADES, Andreas. Recasting the Power Politics of Debt: structural power, hegemonic stabilisers and change. Third World Quarterly, v. 34, n.2, 2013, p. 214-232.

ARMIJO, Leslie Elliott; KATADA, Saori N. Theorizing the Financial Statecraft of Emerging Powers. New Political Economy, v. 20, n. 1, 2015, p. 42-62.

BAN, Cornel; BLYTH, Mark. The BRICs and the Washington Consensus: An introduction. Review of International Political Economy, v. 20, n. 2, 2013, p. 241-255.

CAMMACK, Paul. The Governance of Global Capitalism: A New Materialist Perspective. Historical Materialism, vol. 11, n.2, 2003, p. 37-59.

CHANDHOKE, Neera. Realising Justice. Third World Quarterly, v. 34, n. 2, 2013, p. 305-320. FOURCADE, Marion. The material and symbolic construction of the BRICs: Reflections inspired by the RIPE Special Issue. Review of International Political Economy, v. 20, n. 2, 2013, p. 256-267. 
GOLUB, Philip S. From the New International Economic Order to the G20: how the 'global South' is restructuring world capitalism from within. Third World Quarterly, v. 34, n.6, 2013, p. 1000-1015.

GRAY, Kevin; MURPHY, Craig N. Introduction: rising powers and the future of global governance. Third World Quarterly, v. 34, n. 2, 2013, p. 183-193.

HUELSZ, Cornelia. Middle Power Theories and Emerging Powers in International Political Economy: A Case Study of Brazil. University of Manchester (PhD): Faculty of Humanities, School of Social Sciences, 2009.

KATARIA, Anuradha. Future of BRICS - the world is not flat! International Affairs Forum, v. 4, n. 2, 2013, pp. 142-144.

MITTELMAN, James H. Global Bricolage: emerging market powers and polycentric governance. Third World Quarterly, v. 34, p. 1, 2013, p. 23-37.

PANT, Harsh V. The BRICS Fallacy. The Washington Quarterly, v. 36, n. 3, 2013, p. 91-105. POORSAFAR, Hamid. BRICing down? A new normal for the BRICs. International Affairs Forum, v. 4, n. 1, 2013, p. 59-61.

ROBINSON, William I. Global Capitalism Theory and the Emergence of Transnational Elites. Working Paper No 02. UNU-WIDER. 2010.

ROBINSON, William I. he transnational state and the BRICS: a global capitalism perspective. Third World Quarterly, v. 36, n.1, 2015, p. 1-21.

SAAD-FILHO, Alfredo. The 'Rise of the South': Global Convergence at Last? New Political Economy, v. 19, n. 4, 2014, p. 578-600.

SACHS, Goldman. Building Better Global Economic BRICs. Global Economics Paper No. 66, 2001.

STARRS, Sean. The Chimera of Global Convergence. New Left Review, n. 87, 2014, p.81-96. STEPHEN, Matthew D. Rising powers, global capitalism and liberal global governance: A historical materialist account of the BRICs challenge. European Journal of International Relations. 2014, p.1-27.

TAYLOR, Yan. 'The South Will Rise Again'? New Alliances and Global Governance: The India-Brazil-South Africa Dialogue Forum. Politikon, v. 36, n.1, 2009, p. 45-58. THAKUR, Ramesh. How representative are brics? Third World Quarterly, v. 35, n. 10, 2014, p. 1791-1808.

VAN DER WESTHUIZEN, Janis. Falling on Fertile Ground? The Story of Emerging Powers' Claims for Redistribution and the Global Poverty Debate. Global Society, v. 26, n. 3, 2012, p. 331-350.

VANAIK, Achin. Capitalist Globalisation and the Problem of Stability: enter the new quintet and other emerging powers. Third World Quarterly, v. 34, n,2, 2013, p. 194-213. WANSLEBEN, Leon. Dreaming with BRICs. Journal of Cultural Economy, v. 6, n. 4, 2013, p. $453-471$. 


\title{
A path dependence na inserção internacional da Guiana
}

\author{
Path dependence and Guyana's \\ international insertion
}

DOI: $10.21530 /$ ci.v12n1.2017.613

Marcelino Teixeira Lisboa ${ }^{1}$

Ronaldo Silva ${ }^{2}$

\section{Resumo}

Este texto trata da inserção internacional da Guiana através da adesão a processos de integração e organizações internacionais no período de 1966 a 2015. O objetivo é demonstrar como a inserção guianense nesse aspecto criou, ao longo do tempo, uma dependência da trajetória adotada logo após a independência. A análise é realizada com base nos preceitos da path dependence, entendida como uma dependência gerada pela trajetória traçada em determinado caminho, escolhido em um dado momento histórico, dependência essa que se consolida a cada passo trilhado na mesma trajetória. Concluiu-se que, no período analisado, a Guiana teve um eixo de sua integração voltado para a Europa e outro para o Caribe, a partir dos anos de 1970, que seguiram sendo reforçados ao longo do tempo; a partir dos anos 2000, o país passou também a aderir a processos voltados para a América Latina, mas sem deixar as relações anteriores, ramificando sua inserção internacional, que foi institucionalizada desde a sua independência.

Palavras-chave: Guiana; Inserção internacional; Path dependence; Política externa.

\begin{abstract}
This text addresses the international insertion of Guyana through the adherence to integration processes and international organizations in the period from 1966 to 2015 . The objective is to demonstrate how the Guyanese relations have become dependent on the trajectory adopted shortly after independence. The analysis is based on the precepts of path dependence,

1 Professor do Curso de Relações Internacionais e Integração da Universidade Federal da Integração Latino Americana (UNILA). E-mail: marcelino.lisboa@yahoo.com.br

2 Mestrando do Programa de Pós-Graduação em Integração Contemporânea da América Latina (PPG-ICAL). E-mail: ronaldosilvars@hotmail.com

Artigo submetido em 14/01/2017 e aprovado em 16/03/2017.
\end{abstract}


understood as dependence generated by the trajectory traced in a particular path, chosen at a given historical moment and consolidated with each step taken in the same trajectory. It was concluded that in the period analyzed Guyana had one axis of its integration turned to Europe and another to the Caribbean, from the 1970s, which was reinforced over time; from the 2000s on, the country began to adhere to processes aimed at Latin America, but without abandoning previous relations, branching out the international insertion that was institutionalized since its independence.

Keywords: Guyana; International relations; Path dependence; Foreign policy.

\section{Introdução}

A República Cooperativa da Guiana ${ }^{3}$ é um país independente desde 1966, até quando era uma colônia inglesa. Em 2016, o país completou 50 anos de independência, com liberdade de definir suas diretrizes políticas e seu modelo de inserção internacional. Durante esse meio século, diversas mudanças ocorreram no cenário internacional, tal como o fim da Guerra Fria, períodos de governos militares, redemocratização e crises econômicas. Além desses, outros dois acontecimentos relevantes foram a criação de diversas organizações internacionais e o avanço de processos de integração entre os Estados. Dentro dessa temática, este texto discorre acerca dos processos de integração e das organizações internacionais a que a Guiana aderiu ao longo de sua curta história como país independente, buscando a resposta à seguinte questão: qual foi a trajetória traçada pela Guiana em sua inserção internacional, no que diz respeito à sua adesão a processos de integração e participação em organizações internacionais?

A partir dessa indagação, o objetivo do artigo é demonstrar como a inserção internacional da Guiana, relativamente aos processos de integração e da participação em organizações internacionais, passou por alguns momentos decisórios cujas alternativas adotadas foram influenciadas por condições historicamente construídas; além disso, tais alternativas foram reforçadas ao longo do tempo. Para tanto, aborda-se a inserção internacional da Guiana a partir da visão da path dependence,

3 O nome tão singular do país foi instituído em 23 de fevereiro de 1970, quando deixou de fazer parte da monarquia britânica e passou a utilizar o termo "Co-operative" no nome oficial. Nessa ocasião, foi instituído um terceiro setor na economia, o cooperativo, que deveria ter primazia em relação ao setor estatal e ao privado. De acordo com a Constituição de 1970, o cooperativismo passaria a ser o princípio dinâmico da transformação socialista, passando a permear toda as inter-relações sociais (GUYANA, 1970). Um exemplo da importância do setor cooperativo são as instituições econômicas estatais criadas, como Guyana National Cooperative Bank, Guyana Agricultural Co-operative Development Bank, Guyana National Cooperative Bank Trust Company (LIMA, 2011). 
cujas ferramentas permitem um ponto de vista que considera os fatores históricos, as decisões tomadas e a abordagem das relações - causais ou não - entre os eventos ao longo do tempo.

O recorte temático define o primeiro contributo do artigo, que é o de colaborar para um melhor entendimento das relações internacionais da Guiana, visto que ainda é um Estado pouco explorado pela literatura das relações internacionais no Brasil. A justificativa para se analisar a adesão da Guiana aos processos de integração e às instituições internacionais, deve-se ao fato de que são itens da pauta da política externa do país presentes em todo o período analisado e nos quais observam-se mudanças passíveis de serem examinadas a partir da proposta metodológica. A segunda contribuição é de cunho teórico, realizando uma abordagem a partir de ferramentas conceituais e metodológicas ainda pouco comuns no campo das relações internacionais, com a análise a partir da path dependence. Apesar de possuir elementos úteis para as relações internacionais, tal perspectiva ainda é relativamente nova no campo científico, se for considerado que sua sistematização como teoria ocorreu na década de 1990 na economia e nos anos 2000 na ciência política, sendo que, nas relações internacionais, ainda é uma ferramenta a ser explorada e desenvolvida.

A Guiana passou por duas fases distintas de domínio da cena política por determinados grupos, cujos períodos de governo servem para organizar o presente texto. A primeira fase ocorreu desde a independência, em 1966, até 1992, tendo no governo o People's National Congress/Reform (PNC/R), partido que manteve as cadeiras de presidente e primeiro-ministro no período. A segunda fase ocorreu de 1992 a 2015, quando o domínio foi do People’s Progressive Party/Civic (PPP/ CIVIC). Além da introdução e da conclusão, o texto possui três partes, sendo a primeira referente à discussão sobre a path dependence, a segunda sobre o período do governo do PNC/R e a terceira abordando o governo do PPP/CIVIC.

\section{Path dependence: origem e elementos constitutivos}

O institucionalismo histórico é um ramo de estudos das ciências que associa as decisões tomadas pelos atores aos arranjos institucionais existentes, considerando ainda que existe uma relação causal social entre uma decisão tomada em um dado momento e seus efeitos futuros. De forma mais simplificada, pode-se dizer que a história importa e as instituições moldam as ações dos indivíduos. 
Além da causalidade histórica, a perspectiva histórico-institucional considera que cada passo na direção de uma determinada trajetória consolida o caminho escolhido e gera uma dependência de certos fatores presentes nesse percurso, ou seja, uma dependência da trajetória ou path dependence ${ }^{4}$.

A conceituação e o desenvolvimento da ideia de path dependence tiveram sua gênese na economia, a partir das críticas às premissas da economia neoclássica, tendo como precursores Brian Arthur, com a teoria dos retornos crescentes (increasing returns) (ARTHUR, 1994), e Paul David, que abordou o fenômeno como um irreversível processo de ramificação (branching) (DAVID, 1997). Na ciência política, Paul Pierson foi um dos responsáveis pela difusão do debate a partir da path dependence, considerando a ideia de increasing returns, bem como a importância do momento (timing) e da sequência de eventos (sequence) que levam a uma mudança institucional (PIERSON, 2000)5.

Ruth Berins Collier e David Collier trouxeram para tal debate uma questão que faz parte das abordagens de Arthur, David, Pierson e outros, aprofundando a discussão sobre a forma como conjunturas críticas (critical junctures) afetam um fenômeno path dependent (COLLIER; COLLIER, 2002). Aproximando-se de questões metodológicas, James Mahoney realizou uma explanação sobre a utilização das ferramentas metodológicas da path dependence para estudos sociológicos (MAHONEY, 2000). Andrew Bennett e Colin Elman trataram de questões metodológicas envolvendo a path dependence, demonstrando como o uso da comparação e do process tracing podem esclarecer casos de dependência da trajetória (BENNETT; ELMAN, 2006), além de destacar que os estudos qualitativos cada vez mais têm focado na busca de teorias que envolvam diferentes formas de compreensão, sendo que path dependence é uma das opções que podem levar à resolução das problemáticas de pesquisa (BENNETT; ELMAN, 2008).

Embora os estudos comparados e estudos históricos que abordam os efeitos de decisões passadas no desenvolvimento futuro tenham uma longa tradição na ciência política, a path dependence passou a ser mais utilizada, tanto na economia como na ciência política e em outros campos de estudo, a partir do trabalho de Brian Arthur (1994), por conta da sua definição de uma teoria das condições que

4 Optou-se por utilizar a denominação dos conceitos em inglês para manter os termos apresentados pelos autores utilizados e para evitar equívocos com o uso de palavras semelhantes à tradução em português no corpo do texto.

5 Para Pierson, alguns aspectos dos processos políticos que não estão presentes na economia e que devem ser considerados em análises de dependência da trajetória, tais como o papel da ação coletiva, a densidade das instituições, as assimetrias de poder e a complexidade intrínseca aos processos políticos (PIERSON, 2004). 
produzem a dependência da trajetória. No campo das relações internacionais, apesar de também ser possível encontrar uma produção científica com análises a partir da path dependence, trata-se de trabalhos com discussões recentes ${ }^{6} \mathrm{e}$ em pouca quantidade? . Uma questão que frequentemente surge, quando certas abordagens são pouco utilizadas em determinada área, é se tal carência poderia estar relacionada à insuficiência de tal abordagem para um dado objeto. No caso em questão, alguns trabalhos têm demonstrado o potencial da path dependence para o campo de estudo das relações internacionais.

No debate sobre a posição da path dependence nos estudos em relações internacionais, Andrew Hurrel e Terry Macdonald discutem como a moral, a ética e as ideias influenciam o comportamento político e como o comportamento moral é influenciado pela dinâmica das mudanças na política global. Situam a path dependence no campo da visão racionalista, destacando como as normas afetam os resultados de uma decisão política (HURRELL; MACDONALD, 2013). Duncan Snidal ressalta que, nas relações internacionais, a rational choice não é suficiente para realizar predições, enquanto que os estudos históricos são insuficientes para explicar as mudanças de status quo entre anarquia e cooperação. Para o autor, a path dependence, apesar de sofrer críticas e possuir limitações, pode dialogar com essas perspectivas e servir como ferramenta complementar (SNIDAL, 2013). John Ikenberry defende que o institucionalismo histórico apresenta ferramentas de análise - como a path dependence, os increasing returns e as critical junctures - que podem esclarecer fenômenos que as abordagens baseadas na análise de distribuição de poder no sistema internacional não são capazes de explicar, tais como mudanças na ordem mundial (IKENBERRY, 2016). Emmanuel Adler, um dos teóricos do construtivismo nas relações internacionais, em texto que debate a evolução dessa perspectiva na disciplina, afirma que o construtivismo não utiliza a história como um método descritivo, mas como parte da própria teoria. Para Adler, a historicidade na perspectiva construtivista emerge em processos de path dependence que envolvem a relação agente-estrutura e que explicam os mecanismos envolvidos em uma mudança de trajetória (ADLER, 2013). Em um estudo sobre as teorias do desenvolvimento nas relações internacionais,

6 O livro de Fioretos, Falleti e Sheingate (2016) possui 38 capítulos sobre institucionalismo histórico e uma seção com 8 artigos com temáticas exclusivas das RI, dos quais apenas dois utilizam a path dependence em suas análises.

7 O Handbook of International Relations (CARLSNAES; RISSE; SIMMONS, 2013) apresenta 33 capítulos, dos quais apenas quatro discutem em alguma medida a path dependence, sua importância e potencial como ferramenta analítica para as RI. No entanto, em nenhum deles essa perspectiva é utilizada como metodologia ou apoio teórico. 
Jana Hönke e Markus Lederer destacam a importância da path dependence na literatura neoinstitucionalista que debate a teorização do desenvolvimento, tal como na análise da distribuição de recursos por parte de determinados Estados, em benefício de suas colônias (HÖNKE; LEDERER, 2013).

Ainda que escassas, podem ser encontradas, na esfera das relações internacionais, abordagens que utilizam a path dependence como ferramenta metodológica, como etapa de análise através do institucionalismo histórico ou como base teórica para formulação de hipóteses. Etel Solingen e Wilfred Wan analisam as divergências entre os paths da segurança regional no Leste Asiático e no Oriente Médio, além do regime de não proliferação de armas nucleares, utilizando o institucionalismo histórico. Concluem que a path dependence é pertinente para entender um tratado que separa os Estados em duas classes, os nucleares e os não nucleares. Também demonstram que a path dependence pode revelar que as mesmas propriedades em um fenômeno não geram os mesmos resultados em diferentes situações (SOLINGEN; WAN, 2016). Mahoney, em estudo comparativo sobre a mudança de regime político nos países da América Central no final do século XIX e início do século XX, apoia-se na path dependence para formulação de suas hipóteses e definição de seus argumentos, bem como as variáveis de seu modelo analítico (MAHONEY, 2001). Stefan Hedlund realizou um estudo sobre a path dependence na economia política internacional da Rússia, utilizando os postulados de Brian Arthur, por sugestão de Paul David, analisando como a dependência da trajetória influenciou historicamente as relações da Rússia com outros países e regiões (HEDLUND, 2005). Embora a pesquisa realizada por Mahoney seja mais próxima da ciência política e a de Hedlund mais ligada à economia, ambos trazem importantes aportes do uso da path dependence que podem ser observados pela ótica das relações internacionais. Esses trabalhos exemplificam as possibilidades de uso da path dependence nas relações internacionais, bem como a necessidade do desenvolvimento de um arcabouço teórico-metodológico agregado a esta área da ciência.

\section{Path dependence como modelo de análise}

A path dependence, a partir da perspectiva do desenvolvimento histórico, tal como citado anteriormente, pode ser entendida como uma dependência gerada pela trajetória traçada em determinado caminho, escolhido em um dado momento histórico, dependência essa que se consolida a cada passo trilhado na mesma 
trajetória. Quanto a essa afirmação, não há divergências entre os estudiosos do tema, sejam da economia, da ciência política ou das relações internacionais. No entanto, é necessário um melhor entendimento dos mecanismos que envolvem a path dependence para a sua utilização como um modelo analítico. Nesse tópico do texto, são apresentados os conceitos utilizados na análise deste artigo: a) critical juncture; b) contingent event; c) antecedent conditions; d) self reinforcing.

Critical junctures são períodos nos quais há a seleção de uma opção dentre diversas alternativas (MAHONEY; SCHENSUL, 2006), gerando um movimento na direção selecionada e um processo causal relacionado à alternativa eleita (COLLIER; COLLIER, 2002). Mahoney desenvolve a ideia de que as critical junctures são momentos de escolha nos quais uma opção é adotada em detrimento das demais, tornando progressivamente mais difícil retornar ao ponto inicial no qual múltiplas alternativas estavam disponíveis, gerando uma trajetória que não pode ser facilmente interrompida ou revertida (MAHONEY, 2001). Complementa com a afirmativa de que, quando as condições que precedem uma critical juncture podem predizer ou explicar os resultados da decisão tomada, a sequência de eventos que se sucederem não podem ser considerados path dependents. Sendo assim, uma critical juncture é uma condição presente no início de uma trajetória dependente ou em momentos de tomada de decisão dentro dessa trajetória. Além disto, a definição de uma critical juncture auxilia no problema do estabelecimento do quanto se deve retornar ao passado para explicar um fenômeno, ou seja, serve como base para o recorte da pesquisa (MAHONEY, 2001).

Assim, como as critical junctures, um contingent event está ligado às condições iniciais de uma trajetória dependente. Entretanto, há grandes diferenças sobre o entendimento desse elemento na path dependence. Alguns autores consideramno como um fator aleatório e inexplicável com efeito causal nos momentos de critical junctures, enquanto que outros consideram que possa ser um elemento explicável, mas exógeno ao fenômeno em análise, além de necessário para que ocorra a path dependence. Outros autores consideram que o contingent event não é condição suficiente e nem necessária para a existência da path dependence (BERNARDI, 2012). Adota-se, neste trabalho, a premissa mais geral de que um contingent event é um acontecimento ligado à fase inicial de um processo path dependent e às critical junctures, mas considera-se também a posição de Kathleen Thelen de que as trajetórias políticas não são necessariamente desencadeadas por um evento inicial contingente, pois suas origens podem estar mais fortemente ligadas às antecedent conditions (THELEN, 1999). 
As antecedent conditions são características historicamente construídas, que definem a extensão das alternativas disponíveis aos decision makers, mas não determinam qual alternativa será escolhida (CAPOCCIA, 2015). Como parte das antecedent conditions, Capoccia aponta que atores estrategicamente dispostos nos momentos de critical junctures podem usar sua posição para difundir ideias que legitimam uma escolha em particular, prevalecendo sobre outros grupos sociais. Quando essa batalha de ideias encontra um vencedor, as ações coletivas passam a ocorrer no sentido da construção e do suporte ao caminho escolhido (CAPOCCIA, 2015). Mahoney e Schensul (2006), assim como Collier e Collier (2002), concordam com Capoccia na afirmativa de que as antecedent conditions são elementos necessariamente existentes antes das critical junctures e da ocorrência de crises ou cleavages. Assim, as antecedent conditions podem ser entendidas como as características de um fenômeno, que antecedem um momento de crise e levam a uma critical juncture, na qual ocorrerá a tomada de decisão.

As antecedent conditions, critical junctures e contingent events são elementos que caracterizam o processo inicial de uma condição path dependent. Todavia, para que se produza a dependência da trajetória é necessário que a opção selecionada seja reproduzida, tomando atitudes que reforcem a decisão anterior. Na economia, a abordagem mais comum para explicar a razão pela qual uma opção selecionada é reproduzida são os increasing returns ou feedbacks positivos, ligados a uma abordagem utilitarista e racional. No caso da política, que se aplica também às relações internacionais, é importante resgatar a afirmação de Pierson de que a retroalimentação de uma trajetória deve considerar a possibilidade de uso da posição de um determinado ator nas disputas de poder (PIERSON, 2004), frequentemente assimétricas. Devido a tais características, utiliza-se neste texto o termo self reinforcing para designar as ações voltadas a reproduzir uma opção. Entende-se que o termo increasing returns (ARTHUR, 1994) é mais útil em análises com base racionalista. Também não se utiliza a expressão positive feedback (PIERSON, 2000), empregada com frequência de maneira intercambiável com self reinforcing, pois entende-se que o positive feedback, assim como os increasing returns, são os fatores motivadores para uma ação de self reinforcing.

A partir da visão de que os mecanismos que definem a fase inicial de uma condição de path dependence são diferentes daqueles que reproduzem tal condição (COLLIER; COLLIER, 2002), é possível entender o self reinforcing como uma decisão ligada à opção inicial ou influenciada por ela, que necessariamente conduz a trajetória ao lock-in ou situação de irreversibilidade da trajetória. Nesse 
caso, o custo da transição para uma alternativa torna-se inviável, permitindo apenas a adoção de opções que gerem um processo de branching, que se trata de um padrão de mudanças que se restringem a ramificações dentro da mesma trajetória (DAVID, 1997). Essa limitação de escolhas que se acentua ao longo do horizonte histórico é um dos temas sobre os quais há uma quase unanimidade entre os estudiosos da path dependence, que consideram que as escolhas feitas na fase de formação de uma instituição ou da definição de uma política terão influência determinante e contínua ao longo do tempo. Em um processo path dependent em que ocorrem sequências de self reinforcing, as critical junctures são períodos de gênese institucional (MAHONEY, 2000) ou mesmo de mudanças dentro de um mesmo processo de path dependence (MAHONEY; MOHAMEDALI; NGUYEN, 2016). O self reinforcing é uma etapa posterior à critical juncture, que reproduz uma opção selecionada anteriormente, promovendo uma persistência do caminho, gerando o lock-in, e tornando a dinâmica mais path dependent a cada passo na trajetória.

A partir da explanação dos conceitos ligados à path dependence que são utilizados na presente análise, pode-se definir a path dependence, para o objetivo deste artigo, como uma situação iniciada em uma critical juncture, na qual ocorreu uma tomada de decisão influenciada por antecedent conditions e que permaneceu ativa por conta do mecanismo de self reinforcing, levando ao lock-in institucional. Entretanto, é importante acrescentar que uma trajetória dependente pode ser substituída em momentos de ruptura da trajetória (path broken) ou alterada pelo mecanismo de branching dentro dos padrões impostos pela escolha realizada na fase de critical juncture. As seções seguintes do texto abordam o estudo do caso da Guiana, considerando os elementos da path dependence.

\section{Europa e Caribe na Agenda: o Governo do PNC/R (1966-1992)}

A Guiana tornou-se independente da Inglaterra em 1966, sendo que, no período desde a independência até 1970, teve a rainha Elizabeth II da Inglaterra como chefe de Estado e o primeiro-ministro, Forbes Burnham, do PNC/R, como chefe de governo. O período, que se iniciou em 23 de fevereiro de 1970 na Guiana, marcou o início da sua história como um Estado republicano, a República Cooperativa da Guiana, desfazendo os laços institucionais de governo com a monarquia britânica. O primeiro presidente republicano foi Arthur Chung (1970-1980), que não era 
filiado a nenhum partido na ocasião de sua eleição, que ocorreu de forma indireta, através dos votos dos parlamentares da Assembleia Nacional.

Durante todo o governo Chung, Burnham continuou sendo o primeiro-ministro e era quem exercia o poder de fato, utilizando-se de sua liderança político-partidária e da sua condição constitucional de principal assistente do presidente nas questões do executivo, principalmente na função de líder do governo perante a Assembleia Nacional. Em 1980, Burnham foi eleito presidente da Guiana, governando entre 1980 e 1985, quando faleceu e foi substituído pelo primeiro-ministro Desmond Hoyte, também do PNC/R, que governou até 1992. No período em que o PNC/R dominou a cena política, principalmente nos primeiros anos da Guiana republicana, foram tomadas as primeiras decisões em relação à inserção internacional e à política externa guianense, inclusive nos temas relativos à incorporação a processos de integração e adesão a organizações internacionais, como o CARICOM, ou manutenção de relações anteriores à independência, tal como a Commonwealth.

\section{A commonwealth e o ACP Group of States}

A British Commonwealth, foi institucionalizada em 1931 pelo governo britânico através do Estatuto de Westminster, como consequência da Conferência Imperial da Commonwealth de 1926. A principal alteração que a Commonwealth trouxe às colônias britânicas foi a mudança de sua condição de territórios coloniais para domínios autônomos, iguais em status, nenhum deles sendo subordinado aos demais, unidos pela fidelidade à Coroa e livremente associados como membros da Commonwealth. O estatuto previa ainda a autonomia legislativa de cada unidade e o direito de deixar de fazer parte da instituição quando assim desejasse (UNITED KINGDOM, 1931).

Em 1932, foi incluída uma dimensão econômica com a criação da Commonwealth Preference, um sistema que eliminou as tarifas dos produtos que a Inglaterra comprava de seus domínios; nessa ocasião, a Coroa recomendou que os domínios passassem também a realizar tal prática entre si. Essas medidas fizeram com que a Commonwealth atuasse como um bloco econômico nos anos seguintes, com o comércio entre seus membros vindo a reduzir-se somente ao final dos anos 1960 (FEDERAL RESEARCH DIVISION, 1993). Outro ponto importante é que os domínios tinham como autoridade máxima o representante da Coroa, ou seja, o monarca britânico. Aos domínios que alcançaram a sua independência, ficava a prerrogativa de manter a monarquia na função de chefe de Estado ou desfazer 
tais laços, o que não implicava retirada da Commonwealth, somente a condição de fazer parte do Reino da Commonwealth, composto por monarquias parlamentaristas independentes que compartilham o chefe de Estado.

No caso da Guiana, após a independência o país manteve-se na categoria de Reino da Commonwealth até a posse do presidente Chung, em 1970, quando se instaurou o modelo republicano e, ainda assim, a Guiana optou por seguir participando da Commonwealth. Na visão de Joshua Hyles, uma das principais motivações para que a Guiana permanecesse na Commonwealth era manter a possibilidade de solicitação de auxílio aos britânicos no caso da disputa territorial que ocorria com a Venezuela, pois o apoio inglês seria um freio às pretensões do país vizinho, caso esse resolvesse utilizar a força para a resolução da questão fronteiriça (HYLES, 2013). George Fauriol concorda com Hyles e acrescenta que uma segunda motivação era seguir usufruindo dos benefícios comerciais providos pelas preferências tarifárias (FAURIOL, 1993). Nesse caso, há que se destacar que, após a Segunda Guerra Mundial, as trocas comerciais entre os membros da Commonwealth reduziram-se, com a situação se agravando quando a Inglaterra passou a compor a Comunidade Econômica Europeia (CEE), o que levou a Commonwealth Preference a ser gradualmente abolida, sendo extinta em 1977 (FEDERAL RESEARCH DIVISION, 1993).

A realidade que a Commonwealth construiu desde os anos 1930 entre a Inglaterra e suas colônias deu a tônica das antecedent conditions que o primeiro governo da Guiana independente encontrou no momento de decidir as diretrizes internacionais do país, influenciando para que o país se mantivesse mais inclinado à Europa em suas relações internacionais. A independência da Guiana pode ser entendida como uma critical juncture, pois foi o momento no qual os governantes tiveram a possibilidade de escolher uma alternativa entre várias disponíveis, visto que, além da Commonwealth, havia a possibilidade de alinhamento com uma das grandes potências da Guerra Fria, reduzindo os laços com o eixo europeu. Todavia, a Guiana optou por manter os laços com a Commonwealth e aderir ao Non Aligned Movement (NAM), adotando uma política interna de cunho socialista, mas com uma política externa de neutralidade em relação às grandes potências. Assim, a Commonwealth foi a opção de inserção internacional vista como mais viável, em detrimento do alinhamento às grandes potências. Destarte, a adesão ao NAM e a posição neutra na Guerra Fria não significaram inexistência de relações da Guiana com os Estados Unidos ou com a União Soviética, pois as relações diplomáticas e comerciais ocorreram com ambos. 
O que é relevante para uma análise com base na path dependence é que a Guiana iniciou sua trajetória independente em uma critical juncture, que foi a fase imediatamente posterior à independência. Nessa situação, a decisão pela manutenção das relações com a Commonwealth, como principal linha de inserção internacional, foi o resultado das antecedent conditions construídas pela própria Commonwealth e de um contingent event, que era o conflito fronteiriço com a Venezuela. Ambas as causas podem ser consideradas uma herança colonial, pois a forte ligação com a Commonwealth foi institucionalizada pela Inglaterra no período colonial, enquanto que o conflito fronteiriço também é um tema sem solução desde 1814, quando a Convenção de Londres passou a região para o comando britânico.

Após a fase de critical juncture do pós-independência e o aprofundamento das relações com a Commonwealth, a Guiana ficou sujeita às flutuações inerentes às situações de path dependence. Com o avanço do processo de institucionalização da integração na Europa e a adesão definitiva do Reino Unido à Comunidade Econômica Europeia (CEE), em 1973, o eixo estrutural econômico da Commonwealth alterou-se, levando a modificações nas preferências tarifárias dos países da comunidade com o Reino Unido, as Commonwealth Preferences. Em fevereiro de 1975 foi assinada a Convenção de Lomé, entre os Estados partes do tratado que estabeleceu a CEE e os países que passariam a compor o African, Caribbean and Pacific Group of States (ACP). Tal convenção tinha o objetivo de promover a cooperação comercial entre as partes contratantes, levando em conta o nível de desenvolvimento de cada um dos países e a necessidade de se assegurar benefícios adicionais aos países da ACP, para garantir o seu acesso aos produtos da CEE e acelerar suas taxas de crescimento (THE LOME CONVENTION, 1975). Para os países da Commonwealth, tal como a Guiana, esse tratado serviu como substituição às Commonwealth Preferences, que vinham sendo reduzidas desde 1973 e foram extintas em 1977. Quando a Convenção de Lomé foi assinada, a ACP não existia formalmente, o que ocorreu somente em junho de 1975, através do Tratado de Georgetown, que denominou o conjunto dos países signatários como ACP-Group of States (THE GEORGETOWN AGREEMENT, 1975).

A adesão à ACP representou um aprofundamento das relações com a Europa, pois o tratado foi assinado com o bloco de países e não mais com o Reino Unido. A realidade guianense, quando foram eliminadas as Commonwealth Preferences e assinada a Convenção de Lomé, era de um país dependente no contexto internacional, muito mais do que uma nação capaz de conduzir uma política 
externa independente, baseada em algum interesse nacional. Essas condições, assim como decisões anteriores da fase de critical juncture, colocaram a Guiana em uma situação de path dependence com o Reino Unido através da Commonwealth, enquanto que a ACP significou um self reinforcing a tal trajetória, por conta da reprodução da opção escolhida anteriormente.

A persistência estrutural da trajetória selecionada foi ainda reforçada quando foi promulgada a Constituição da República Cooperativa da Guiana, de 1980, que caracterizou outro self reinforcing. A constituição guianense quebrou definitivamente todas as ligações com a monarquia britânica, mas reafirmou sua participação na Commonwealth, citando a instituição em onze dos seus 233 artigos (GUYANA, 1980). Dentre os temas tratados na constituição, o principal é o reconhecimento de cidadania e direitos a cidadãos de outros Estados da Commonwealth residentes na Guiana, com os mesmos direitos de cidadãos guianenses.

A relação com a Commonwealth e com a ACP evidenciam a manutenção de uma trajetória, exatamente nas primeiras décadas após a independência, período em que a Guiana poderia iniciar a superação dos antigos vínculos coloniais. No entanto, as antecedent conditions foram essenciais para determinar a trajetória vinculada aos antigos parceiros europeus e por eles determinada, em detrimento da exploração dos atributos materiais do Estado ou capabilities, tais como poder militar, posse de recursos naturais, características da sociedade e poder econômico.

\section{A agenda regional: CARICOM}

Além da inserção internacional via Europa, o governo guianense, nos anos de 1970, passou também a investir esforços na integração com o Caribe, a partir de 1973, quando o país passou a fazer parte do Caribbean Community and Commom Market (CARICOM). O CARICOM foi institucionalizado em 1973 com a assinatura do Tratado de Chaguaranas por Barbados, Guiana, Jamaica e Trinidad e Tobago, em substituição ao Caribbean Free Trade Agreement (CARIFTA). O CARIFTA era um tratado de livre-comércio criado em 1965, com o intuito de unir as economias dos antigos domínios britânicos no Caribe, que haviam se tornado independentes naquele período, com o objetivo de aumentar sua capacidade de barganha no cenário internacional. Hyles aponta que o CARIFTA não era um processo com a intenção de realizar uma integração pan-caribenha, mas um acordo comercial com o intuito de reagir à mudança do foco da política externa britânica, que se voltava naquele momento totalmente para a Europa (HYLES, 2013). 
Com o avanço da integração europeia e com a participação britânica no processo, também no Caribe os países passaram a tratar a integração de outra forma. O CARIFTA deixou de existir, sendo substituído pelo CARICOM, que possuía objetivos que estavam além do livre-comércio. Melhoria das condições de trabalho e emprego, avanço no desenvolvimento social e cultural, além da intensificação da cooperação em áreas como saúde e educação, eram temas da agenda da instituição. A Guiana teve importante papel em ambos os casos, propondo a ideia do CARIFTA e posteriormente sediando o escritório central do CARICOM. Assim, pode-se perceber que a face caribenha da inserção internacional da Guiana através de processos de integração e de participação em organizações internacionais teve sua gênese na mesma critical juncture em que houve o direcionamento das relações para a Europa, ou seja, a fase da independência. O que se altera é o contingent event, que nesse caso foi a participação britânica no processo de integração europeia. Apesar da ligação entre Europa e Caribe pela ACP, os Estados caribenhos, muitos deles recentemente independentes como a Guiana, perceberam a necessidade de aprofundar as relações regionais geograficamente mais próximas. A Guiana foi protagonista nesses processos, sendo propositora do CARIFTA, que se caracterizou por ser a alternativa selecionada na critical juncture, além de ter a sede do CARICOM, que significou um self reinforcing da inserção internacional regional guianense.

Contudo, nos doze anos (1973-1985) em que o CARICOM esteve em atividade e que Burnham exerceu o cargo de primeiro-ministro e, posteriormente, de presidente da Guiana, as relações com os demais países dentro da instituição foram problemáticas. Dos treze países da comunidade, somente a Jamaica, Granada e a Guiana tinham uma retórica anti-EUA, enquanto que os demais Estados eram marcados por uma política de apoio ao Ocidente e ao capitalismo, o que estava gerando desentendimentos no âmbito decisório do CARICOM, devido ao posicionamento crítico de Burnham em relação aos EUA. Deve-se destacar que o discurso de Burnham não era somente anti-EUA, mas também de críticas à União Soviética, afirmando que o país não serviria de peão nem ao Leste e nem ao Oeste (JACKSON, 2003), mas sem romper os laços com nenhuma dessas nações. A situação agravou-se com a intervenção dos EUA em Granada, em 1983, quando Burnham criticou tanto a ação norte-americana quanto os líderes do CARICOM e da Commonwealth que apoiaram a operação. Com isto, Burnham afastou-se dos demais líderes da Commonwealth, chegando a ameaçar o futuro do CARICOM (FAURIOL, 1993). Tal situação somente foi alterada quando Hoyte substituiu Burnham na presidência. 
Após a morte de Burnham, em 1985, Desmond Hoyte assumiu o governo até 1992. No período de Burnham no governo, não obstante o fato de manter o não alinhamento nas questões políticas, a Guiana tinha laços diplomáticos com os governos comunistas do Leste Europeu, com a União Soviética e com Cuba. Quando Hoyte assumiu o poder, apesar de pertencer aos quadros do PNC/R, adotou uma política externa menos tolerante com as causas socialistas, encerrando a retórica anticapitalista e antiocidental, inaugurando uma nova estratégia para obter apoio das potências ocidentais para a implementação de sua política econômica. As relações com o CARICOM e com os líderes dos países da Commonwealth foram reassentadas, ao passo que, com as nações comunistas, o relacionamento foi não mais que de cordialidade, levando ao arrefecimento ao longo dos anos seguintes (FAURIOL, 1993).

No âmbito da relação com as organizações internacionais, o ponto mais relevante do governo Hoyte foi a adesão à Organização dos Estados Americanos, em 1991. A despeito da adesão somente nesse período, a Guiana pleiteava a participação na organização desde a sua independência, em 1966, mas tinha essa possibilidade vetada pela Venezuela, por conta de um litígio fronteiriço entre os dois países. Apesar da tentativa do Reino Unido de mediar as negociações para a resolução da questão, ainda em 1966, não foi possível realizar um acordo e o conflito se estendeu até 1989, quando o presidente venezuelano era Jaime Lusinchi. Quando Carlos Andrés Pérez assumiu o governo, em substituição a Lusinchi, as negociações se tornaram menos conflituosas e mais cordiais, levando a Venezuela a retirar sua objeção à entrada da Guiana na OEA. Com isso, a partir de 1990, a Guiana passou a fazer parte também da organização, embora o tema fizesse parte da agenda e das diretrizes políticas desde 1966, ano em que a Guiana também aderiu à Organização das Nações Unidas.

\section{Continuidades e novas opções: o Governo do PPP/CIVIC (1992-2015)}

Durante o governo do PPP/CIVIC, ocorreu uma transformação políticoeconômica na qual o grupo governista absteve-se das políticas dos governos anteriores, direcionando sua matriz de inserção internacional a uma abertura econômica e à prática de políticas de livre mercado (FAURIOL, 1993). Em relação à política externa da Guiana e sua relação com as organizações internacionais e processos de integração nesse período, destaca-se a participação em cinco 
instituições: Association of Caribbean States (ACS), União de Nações Sul-Americanas (UNASUL), Comunidad de Estados Latinoamericanos y Caribeños (CELAC) e o Mercado Comum do Sul (MERCOSUL), além do Acordo de Cotonou, no âmbito da ACP. A adesão a tais instituições demonstra tanto ações que representam uma continuidade quanto parcerias que implicam uma mudança na política externa guianense. Ao mesmo tempo, são consequências mais ligadas aos condicionantes externos e ao contexto internacional do que necessariamente uma mudança de planejamento das diretrizes externas do país, visto que as alterações no direcionamento de sua política externa foram influenciadas, em grande medida, pelo avanço da integração europeia e pela consolidação de instituições sul-americanas.

\section{Self reinforcing: ACS e Cotonou}

A Guiana passou a compor a Association of Caribbean States (ACS) desde a sua fundação, em 1994. A ACS constitui-se de conferências de cúpula realizadas por chefes de Estado ou representantes de alto nível, com fins de promoção de cooperação regional e integração econômica entre os países caribenhos, com o objetivo de promover a cooperação e ação concentrada dos Estados membros (ASSOCIATION OF CARIBBEAN STATES, 2012). Para tanto, a ACS identificou áreas de interesse comum aos países membros, como a preservação e conservação do mar do Caribe, o turismo sustentável, o comércio e as relações econômicas internacionais, os desastres naturais e as questões de transporte e infraestrutura.

Ao analisarem-se as áreas de interesse dos países membros, nota-se uma semelhança com diversos temas também tratados pelo CARICOM. No entanto, conforme destaca a própria ACS, enquanto que o CARICOM possui quinze membros, a ACS possui 25 Estados membros independentes, além de oito países associados. Outra diferença entre os dois é que o CARICOM tem seu foco principal em um mercado comum e outras questões econômicas, com o objetivo de gerar um processo de integração. A ACS, por sua vez, é um foro consultivo e deliberativo, que tem o intuito de gerar uma zona de cooperação nas diversas áreas de interesse identificadas (ASSOCIATION OF CARIBBEAN STATES, 2012). Assim, tanto a ACS quanto o CARICOM são instituições das quais a Guiana participa e que estão geograficamente voltadas às questões caribenhas.

Desde a fundação do CARIFTA até a institucionalização da ACS, pode-se considerar que a integração da Guiana voltada para o Caribe completou três 
décadas de desenvolvimento, consolidando um lock-in nessa questão. Os modelos de integração do CARIFTA, do CARICOM e da ACS demonstram uma evolução nos objetivos e na abrangência, sempre com foco no Caribe, reproduzindo a opção guianense dos anos 1960 em um processo de self reinforcing. O caminho traçado pela inserção internacional da Guiana, através da aproximação com países do Caribe, a cada novo evento apresentou decisões alinhadas com o lock-in existente, não contrastando, mas, sim, reforçando a opção inicial.

O mesmo pode-se apontar em relação à opção pela parceria com a Europa pela Commonwealth, que passou por outro self reinforcing no governo do PPP/ CIVIC. No ano de 2000, foi estabelecido um acordo entre o ACP-Group of States e a União Europeia, o ACP-UE, que consiste no estabelecimento de um processo de cooperação. Conhecido como Acordo de Cotonou, esse tratado entrou em vigor em 2003 e é uma continuação e atualização da Convenção de Lomé, representando uma nova fase de cooperação entre ambas organizações. O Acordo de Cotonou alterou as convenções anteriores, promovendo acordos comerciais e de cooperação entre as nações, tendo como objetivos a redução da pobreza e, a longo prazo, a sua erradicação e a integração progressiva dos Estados da África, do Caribe e do Pacífico (ACP) na economia mundial (EUROPEAN COMISSION, 2000). Mesmo antes da convenção entrar em vigência, no ano de 2002, a Guiana iniciou as negociações de Acordos de Parceria Econômica, com uma maior abertura do mercado para serviços e investimentos no âmbito do tratado.

Tanto no eixo europeu como no eixo caribenho da inserção da Guiana, considerando os momentos históricos em que cada um desses processos foi institucionalizado, é possível identificar a interferência de fatores sistêmicos influenciando na criação de tais instituições. Além disso, a condição dependente e periférica da Guiana também impõe limites nas possibilidades de escolha, fato que é característico de qualquer Estado periférico. A path dependence que teve sua gênese na critical juncture da independência, iniciando dois caminhos distintos e complementares para a política externa da Guiana, teve diversos eventos novos ao longo do tempo, cujas decisões estiveram em consonância com o lock-in e geraram self reinforcing. Para ambas as situações, os elementos sistêmicos próprios das relações internacionais geraram contingent events e as características da Guiana, dentro desse sistema internacional, estão ligadas às antecedent conditions de um país que ainda molda sua política independente. Durante o governo do PPP/CIVIC, apesar das divergências ideológicas com o PNC/R, a ACS e o Acordo 
de Cotonou representaram a continuidade e o reforço da trajetória iniciada, no período anterior, pelos governos de Chung, Burnham e Hoyte.

\section{Regionalismo sul-americano: UNASUL, CELAC e MERCOSUL}

Em outra direção, a Guiana participa da União de Nações Sul-Americanas (UNASUL), desde quando a instituição utilizava a antiga sigla CASA, em 2004. Criada em 2008, como etapa posterior da CASA, a UNASUL é uma organização que, desde a sua gênese, visa a criação de um espaço de integração dos povos sul-americanos, uma vez que, no período de seu surgimento, a região passava por profundas transformações políticas, econômicas e sociais. Não obstante, a criação da UNASUL resultou de um processo que buscava o fortalecimento dos países sul-americanos enquanto grupo, servindo inclusive como espaço de discussão e estabilização de conflitos regionais e de integração de infraestrutura física. A organização conta com uma presidência rotativa ${ }^{8}$ e, no período de 26 de novembro de 2010 a 29 de outubro de 2011, o então presidente da Guiana, Bharrat Jagdeo, assumiu tal função.

Para a Guiana, a UNASUL pode representar a oportunidade de resolver a questão relativa à disputa fronteiriça com a Venezuela, visto que o presidente venezuelano, no início de 2015, apontou para a possibilidade de levar a questão para discussão no órgão. Além disso, as eleições presidenciais na Guiana, em 2015, contaram com a participação de uma delegação de observadores da UNASUL (UNASUR, 2016), por solicitação do governo guianense, como forma de demonstrar o compromisso do país com a instituição e com um de seus objetivos, o de promover e preservar a democracia na América do Sul. A UNASUL se caracteriza, portanto, como uma forma de direcionamento da integração ao Sul para a Guiana, dentro das diretrizes de política externa do país.

Verifica-se que, a partir dos anos de 1990 até o início do século XXI, a inserção internacional guianense pela via da integração ocorreu através do estabelecimento de parcerias que aprofundaram os modelos existentes ou os aperfeiçoaram em um mecanismo de self reinforcing. Essa é a constatação quando se averiguam as semelhanças e diferenças entre o CARICOM e a ACS ou entre a Convenção de Lomé e o Tratado de Cotonou, que representaram uma atualização dos processos

8 A lista dos presidentes pro tempore da UNASUL está disponível no site da instituição: < https://goo.gl/R60DlV > . Acesso em: 22 de dezembro de 2017. 
herdados dos anos de 1970, que, por sua vez, têm raízes ainda mais longínquas, nas antecedent conditions. Todos esses exemplos, cada um com suas especificidades, derivam da participação da Guiana na Commonwealth desde o período colonial. A UNASUL, por sua vez, representou um ponto de inflexão, pois foi o primeiro processo de integração ao qual a Guiana aderiu que não tem como foco principal o Caribe e cuja matriz encontra-se na América Latina.

Esse é um fato relevante, pois, após esse período, o país inseriu-se em outros processos integracionistas latino-americanos, a partir do início da segunda década do século XXI, em decisões que contrastaram com o lock-in da inserção internacional voltada para a Europa e o Caribe. No entanto, não se pode caracterizar a adesão da Guiana à CASA, em 2004, e à UNASUL, em 2008, como um path broken ou uma nova critical juncture nas diretrizes de inserção internacional do país em processos de integração ou participação em instituições internacionais, pois, para tal, seria necessária uma alteração na trajetória, substituindo-a por uma alternativa concorrente. No caso em questão, a opção pela UNASUL deveria substituir ao menos uma das opções anteriores, as relações com o Caribe ou com as instituições europeias, o que não ocorreu. Sendo assim, a path dependence, em relação à Europa e ao Caribe, e o lock-in, institucionalizado ao longo das primeiras quatro décadas da Guiana independente, não foram alterados por conta do eixo latino-americano da inserção internacional guianense que se abriu no início do século XXI.

Em relação ao novo eixo da inserção guianense, uma importante relação estabelecida pelo governo do PPP/CIVIC foi com a Comunidade dos Estados Latino-americanos e Caribenhos (CELAC). A Guiana aderiu à CELAC desde a sua fundação, em 2011, a partir de quando ocorreu uma união progressiva do Grupo do Rio e da Cúpula da América Latina e do Caribe sobre Integração e Desenvolvimento (CALC) em uma única organização. As cúpulas realizadas pela CELAC tornaram-se espaços de diálogo do continente com o resto do mundo, na medida em que têm propiciado o desenvolvimento e a coordenação de relações inter-regionais.

Por ocasião da cúpula ministerial realizada na Costa Rica, em 2015, o ministro de Negócios Estrangeiros da Guiana, Carl Greenidge, declarou que a CELAC permite às nações latino-americanas falarem no contexto de um grupo maior, o que pode ser, para países maiores, uma perspectiva mais atraente do que lidar com países pequenos isoladamente (GOVERNMENT INFORMATION AGENCY, 2016). Ademais, 
Greenidge reforçou tal posição, afirmando que a CELAC deveria buscar relações com a União Europeia e com a União Africana, considerando o posicionamento da América Latina no mundo.

Tanto a CELAC quanto a UNASUL fazem parte de iniciativas surgidas em um momento histórico em que ocorreu um realinhamento em âmbito internacional. A América Latina da primeira década do século XXI estava caracterizada por governos que buscavam alternativas aos modelos integracionistas baseados no regionalismo aberto e em políticas neoliberais, abrindo espaço para novas iniciativas regionais. Nesse contexto, o fortalecimento das relações latino-americanas fez emergir organismos como a UNASUL e a CELAC, que representaram, ao menos parcialmente, a aproximação de Estados que não tinham as suas prioridades em organismos regionais latino-americanos.

Além da UNASUL e da CELAC, também o MERCOSUL representa o direcionamento da política externa guianense para uma maior integração com a América do Sul. O MERCOSUL, criado em 1991, tem como membros efetivos Argentina, Brasil, Uruguai, Venezuela e Paraguai e, como associados, Chile, Peru, Colômbia, Equador e Bolívia, sendo que esse último se encontra em fase de adesão como membro pleno. No ano de 2013, o Suriname e a Guiana tornaram-se Estados associados e, assim, todos os Estados da América do Sul passaram a compor o bloco, como membros plenos ou associados (MERCOSUR, 2013).

A relação entre a Guiana e o MERCOSUL estabelece um marco para os processos de interesse na integração regional. Esse processo é estabelecido pelo Acordo Quadro de Associação entre o MERCOSUL e a República Cooperativa da Guiana, onde as partes consideram a integração regional um instrumento de desenvolvimento social e econômico, de modo que a experiência da integração regional da Guiana no Caribe torna-se benéfica a uma maior aproximação entre o MERCOSUL e o CARICOM. Para tal fim, o acordo de associação entre as partes acorda que o alcance dos objetivos estabelecidos se dará através do diálogo político, da cooperação e de investimentos (MERCOSUR, 2013). Todavia, a adesão da Guiana ao MERCOSUL ainda demanda ações conjunturais com o bloco, uma vez que, com os Estados do MERCOSUL, a Guiana tem promovido apenas relações bilaterais com o Brasil, através de processo de cooperação de tecnologia, formação de recursos humanos, segurança e defesa e de políticas sociais.

A participação da Guiana, desde a gênese da UNASUL, ainda quando se denominava CASA, pode não indicar uma critical juncture na perspectiva de um momento de seleção de uma alternativa em detrimento das demais (MAHONEY; 
SCHENSUL, 2006), mas, se for considerado o contexto, identifica-se um contingent event. O direcionamento das políticas externas de países como o Brasil, a Argentina e a Venezuela, para o fortalecimento do regionalismo latino-americano, levou os demais Estados da região a considerarem essa como uma opção a ser explorada. Com a Guiana não foi diferente e, ao aderir a tais processos, institucionalizou como uma de suas diretrizes de política externa a inserção internacional pelo eixo latino-americano. Se for considerada a perspectiva de que uma critical juncture é um período de gênese institucional (MAHONEY, 2000), pode-se afirmar que a participação na CASA foi a produção de um novo pathway, que passou por três eventos de self reinforcing, quando o país se manteve ativo na UNASUL, posteriormente aderiu à CELAC e, finalmente, ao MERCOSUL.

Como tratado anteriormente, no momento imediatamente seguinte à sua independência, a Guiana manteve as relações com antigos parceiros - Europa e Commonwealth - por conta das antecedents conditions. No caso da aproximação da Guiana em relação aos processos regionais de integração, houve grande influência do timing e das forças políticas que se mobilizavam para que avançasse a integração latino-americana, principalmente por parte do Brasil, da Venezuela e da Argentina. Em ambos os casos, seja pelas condições historicamente construídas ou pelo contexto regional, os condicionantes externos foram fatores preponderantes nas decisões tomadas pelo governo guianense. É inequívoco afirmar que os fatores externos sempre influenciam, em maior ou menor medida, o direcionamento da política externa de qualquer Estado, mas, no caso em questão, os dois momentos em que se verifica as tomadas de decisão mais importantes tiveram influência decisiva do contexto externo.

\section{Conclusões}

A partir da verificação dos processos de integração e das organizações internacionais que a Guiana passou a fazer parte em seu meio século como Estado independente, verificou-se que, nessas cinco décadas, o país passou por pelo menos três caminhos que estão moldando a sua trajetória de inserção internacional.

O primeiro deles está relacionado com os resquícios de um país que foi um dos últimos na América Latina a deixar de ser uma colônia. Trata-se das relações com o Reino Unido, que tornaram a Commonwealth uma das opções de parcerias internacionais da Guiana independente. Posteriormente, os Acordos 
de Lomé e Cotonou somente reforçaram tal trajetória. O segundo foi a organização de instituições voltadas à integração do Caribe, como o CARICOM, e mais tarde a ACS, organizações das quais a Guiana também passou a fazer parte com papel protagonista. Esses dois caminhos foram iniciados imediatamente após a independência e foram reforçados ao longo do tempo. O terceiro é a participação em processos voltados para a América Latina - UNASUL, CELAC e MERCOSUL que são mais recentes, mas marcam um novo espaço para a inserção internacional guianense.

Sobre a path dependence, pode-se verificar que, no eixo das relações com a Europa, a participação na Commonwealth foi influenciada pelas antecedent conditions da herança colonial, sendo um dos caminhos selecionados na critical juncture da independência, sofrendo processo de self reinforcing com as convenções de Lomé e Cotonou e com a Constituição de 1980. Nas relações caribenhas, a participação do Reino Unido na integração europeia serviu como contingente event, que gerou o CARIFTA. Posteriormente, o CARICOM e a ACS serviram como self reinforcing a tal processo. O eixo mais recente da integração latino-americana, por sua vez, não significou um path broken, visto que as opções anteriores não foram abandonadas, mas pode ser interpretado como uma critical juncture, devido à gênese institucional ocorrida, ou como um branching, se for considerado que a inserção internacional pela via da integração é uma instituição consolidada na Guiana independente.

Ao se adotar uma opção analítica para pesquisar sobre a ocorrência de determinado fenômeno, mesmo em trabalhos qualitativos, quase que invariavelmente é necessário que se deixem as premissas de outras perspectivas em segundo plano. Ao se analisar o caso da Guiana a partir de um dos enfoques do institucionalismo histórico, a path dependence, outras indagações despontam dentro do objeto em análise. Uma delas é a questão do grau de interdependência ao qual a Guiana tem se submetido ao longo desse meio século, o que permite questionar até que ponto a dependência desenvolvida na trajetória encontra - ou não - uma recíproca em sua outra extremidade, ou seja, nos países dos quais a Guiana depende. Outro ponto seria o papel das capabilities. A análise realizada não partiu da premissa de que as capabilities são um fator de importância secundária na tomada de decisão de um Estado, mas, no caso da Guiana, tais elementos ainda não têm sido explorados em todo o seu potencial, por conta da própria condição dependente e periférica do país. 


\section{Referências}

ADLER, E. Constructivism in International Relations: Sources, Contributions, and Debates. In: CARLSNAES, W.; RISSE, T.; SIMMONS, B. A. Handbook of International Relations. Londres: SAGE, 2013. Cap. 5, p. 112-144.

ARTHUR, W. B. Incresing returns and path dependence in the economy. Ann Arbor: The University of Michigan Press, 1994.

ASSOCIATION OF CARIBBEAN STATES. About The ACS. Association of Caribbean States, 2012. Disponível em: < http://www.acs-aec.org/index.php?q=about/faq > . Acesso em: 15 abr. 2016.

BENNETT, A.; ELMAN, C. Complex Causal Relations and Case Study Methods: The Example of Path Dependence. Political Analysis, n. 14, 2006. 250-267. Disponível em: < https://goo.gl/UCPylO > . Acesso em: 17 jun 2012.

BENNETT, A.; ELMAN, C. Historical Methods. In: REUS-SMIT, C.; SNIDAL, D. The Oxford Handbook Of International Relations. Oxford: Oxford University Press, 2008. Cap. 30, p. 518-538.

BERNARDI, B. B. O Conceito de Dependência da Trajetória (Path Dependence): Definições e Controvérsias Teóricas. Perspectivas, São Paulo, 41, 2012, p. 137-167.

CAPOCCIA, G. Critical junctures and institutional change. In: MAHONEY, J.; THELEN, K. Advances in Comparative-Historical Analysis. Cambridge: Cambridge University Press, 2015.

CARLSNAES, W.; RISSE, T.; SIMMONS, B. A. Handbook of International Relations. Londres: SAGE, 2013.

COLliER, R. B.; COLLIER, D. Shaping the Political Arena: Critical Junctures, the Labor Movement and Regime Dynamics In Latin America. Notre Dame: University Of Notre Dame Press, 2002.

DAVID, P. A. Path Dependence and the quest for historical economics: one more chorus of the ballad of QWERTY. Discussion Papers in Economic and Social History, 1997. EUROPEAN COMISSION. The Cotonou Agreement. Bruxelas: União Europeia, 2000. Disponível em: < https://ec.europa.eu/europeaid/where/acp/overview/cotonouagreement_en > . Acesso em: 11 abr. 2016.

FAURIOL, G. A. Guyana: Government and Politics. In: DIVISION, F. R. Guyana and Belize: country studies. Washington, D.C.: Library of Congress, 1993, Cap. 4, p. 107-130.

FEDERAL RESEARCH DIVISION. Guyana and Belize: country studies. Washington, D.C.: Library of Congress, 1993.

FIORETOS, O.; FAlleti, T. G.; SHEINGATE, A. The Oxford Handbook of Historical Institutionalism. Oxford: Oxford University Press, 2016. 
GOVERNMENT INFORMATION AGENCY. Greenidge to represent Guyana at CELAC Meeting, 2016. Disponível em: < http://www.gina.gov.gy/home/index.php/news/ news-by-ministries/ministry-of-foreign-affairs/item/5229-greenidge-to-representguyana-at-celac-meeting-guyana-attends > . Acesso em: 14 abr. 2016.

GUYANA. Constitution of the Co-operative Republic of Guyana. Georgetown: 1970.

GUYANA. Constitution of the Co-operative Republic of Guyana. Georgetown: 1980.

HEDLUND, S. Russian Path Dependence. Abingdon: Routledge, 2005.

HÖNKE, J.; LEDERER, M. Development and International Relations. In: CARLSNAES,

W.; RISSE, T.; SIMMONS, B. A. Handbook of International Relations. Londres: SAGE, 2013. Cap. 31, p. 775-800.

HURRELL, A.; MACDONALD, T. Ethics and Norms in International Relations. In: CARLSNAES, W.; RISSE, T.; SIMMONS, B. A. Handbook of International Relations. Londres: SAGE, 2013. Cap. 3, p. 57-84.

HYLES, J. R. Guiana and the Shadows of Empire: Colonial and Cultural Negotiations at the Edge of the World. Lanham: Lexington Books, 2013.

IKENBERRY, G. J. The Rise, Character, and Evolution of International Order. In: FIORETOS, O.; FALLETI, T. G.; SHEINGATE, A. The Oxford Handbook of Historical Institutionalism. Oxford: Oxford University Press, 2016. Cap. 32, p. 658-675.

JACKSON, R. Non-alignment and Guyana. Sunday Stabroek, Georgetown, 23 fev 2003. 12A-13A.

LIMA, E. C. L. Política externa do vizinho distante: Estudo de caso da República Cooperativa da Guiana. Tese de Doutorado. 172 f. Universidade de Brasília (UnB) / Universidade Federal de Roraima (UFRR) / Faculdade Latino-Americana de Ciências Sociais (FLACSO-Brasil), 2011.

MAHONEY, J. Path Dependence in Historical Sociology. Theory and Society, 29, n. 4, agosto 2000. 507-548. Disponível em: < http://www.jstor.org/stable/3108585 > . Acesso em: 17 jun 2012.

MAHONEY, J. The Legacies of Liberalism Path Dependence and Political Regimes in Central America. Baltimore: The Johns Hopkins University Press, 2001.

MAHONEY, J.; MOHAMEDALI, K.; NGUYEN, C. Causality and Time in Historical Institutionalism. In: FIORETOS, O.; FALLETI, T. G.; SHEIN, A. The Oxford Handbook of Historical Institutionalism. Oxford: Oxford University Press, 2016. Cap. 4, p. 71-89.

MAHONEY, J.; SCHENSUL, D. Historical Context and Path Dependence. In: GOODIN, R. E.; TILLY, C. Oxford Handbook of Contextual Political Analysis. Oxford: Oxford University Press, 2006. Cap. 24, p. 454-471.

MERCOSUR. Acordo-Quadro de Associação entre o MERCOSUL e a República Cooperativa da Guiana, 11 Julho 2013. Disponível em: < http://www.mercosur.int/innovaportal/ file/5564/1/2013_acordo_mercosul-guaiana_pt.pdf > . Acesso em: 14 abr. 2016. 
PIERSON, P. Increasing returns, path dependence and the study of politics. American Political Science Review, v. 94, n. 2, p. 251-267, 2000.

PIERSON, P. Politics in time: history, institutions, and social analysis. Princeton: Princeton University Press, 2004.

SNIDAL, D. Rational Choice and International Relations. In: CARLSNAES, W.; RISSE, T.; SIMMONS, B. A. Handbook of International Relations. Londres: SAGE, 2013. Cap. 4, p. $85-111$.

SOLINGEN, E.; WAN, W. Critical Junctures, Developmental Pathways, and Incremental Change in Security Institutions. In: FIORETOS, O.; FALLETI, T. G.; SHEINGATE, A. The Oxford Handbook of Historical Institutionalism. Oxford: Oxford University Press, 2016. Cap. 33, p. 676-698.

THE GEORGETOWN AGREEMENT. The Georgetown Agreement (formally establishing the African, Caribbean and Pacific Group of States, the "ACP Group”. Georgetown: ACP Secretariat, 1975. Disponível em: < http://www.wipo.int/wipolex/en/treaties/ text.jsp?file_id $=201070>$. Acesso em: 12 fev. 2016 .

THE LOME CONVENTION. The Lomé Convention. Bruxelas: Comissão Europeia, 1975. Disponível em: < http://www.eurostudium.uniroma1.it/documenti/cooperazione/ Lome_convention.pdf $>$. Acesso em: 12 fev. 2016.

THELEN, K. Historical Institutionalism in Comparative Politics. Annual Review of Political Science, 2, 1999. 369-404.

UNASUR. Memoria Anual 2014-2015. Quito: Union de Naciones Suramericanas, 2016.

UNITED KINGDOM. Statute of Westminster. Londres: Her Majesty's Stationery Office and Queen's Printer of Acts of Parliament, 1931. Disponível em: < http://www.legislation. gov.uk/ukpga/1931/4/pdfs/ukpga_19310004_en.pdf > . Acesso em: 14 jan. 2016. 


\title{
Estudos da paz: origens, desenvolvimentos e desafios críticos atuais
}

\author{
Peace studies: origins, developments \\ and current critical challenges
}

DOI: $10.21530 /$ ci.v12n1.2017.611

Gilberto Carvalho de Oliveira ${ }^{1}$

\section{Resumo}

Embora os estudos da paz coloquem no núcleo da sua agenda de pesquisa alguns dos desafios mais graves e urgentes do nosso tempo - incluindo todas as formas de violência, as causas dos conflitos e as condições para a paz -, é curioso notar a marginalidade, ou quase invisibilidade, dessa disciplina no meio acadêmico brasileiro, bem como a escassez de bibliografia produzida no Brasil dedicada às bases conceituais e metodológicas próprias dessa área de estudos. A fim de contribuir para uma maior visibilidade dos estudos da paz, este artigo tem por objetivo traçar um panorama geral do percurso de consolidação dos estudos da paz como disciplina acadêmica, desde o seu nascimento na década de 1950 até a atualidade. Dentro desse propósito, o artigo procura destacar as origens e os elementos definidores centrais dos estudos da paz, os desenvolvimentos conceituais sobre a violência e a paz ocorridos na obra de Johan Galtung, considerado uma das referências centrais dessa área de estudos, e os principais desdobramentos e desafios dos estudos da paz na atualidade.

Palavras-chave: Conflito, Galtung, Pesquisa da paz, Resolução de conflito, Violência.

\begin{abstract}
Although peace studies put at the core of its research agenda some of the most serious and urgent challenges of our time - including all forms of violence, the causes of conflict and the conditions for peace -, it is curious to note the marginality, or almost invisibility, of this discipline in the Brazilian academia, as well as the scarcity of the literature dedicated to the conceptual and methodological basis of this area of study produced in Brazil. In order to contribute to greater visibility of peace studies, this article aims to outline an overview of the consolidation of the discipline, from its origins in the 1950s to the present. For this
\end{abstract}

1 Professor-Adjunto da Universidade Federal do Rio de Janeiro (UFRJ). Email: gilbertooliv@gmail.com Artigo submetido em 12/01/2017 e aprovado em 19/04/2017. 
purpose, the paper highlights the main defining elements of peace studies, the conceptual developments about violence and peace in Johan Galtung's work, considered one of the central references of the discipline, as well as the main developments and challenges of peace studies today.

Keywords: Conflict, Galtung, Peace research, Conflict Resolution, Violence.

\section{Introdução}

Os estudos da paz constituem a área de pesquisa acadêmica que incorpora o compromisso mais claro e explícito com a não-violência e a organização pacífica das relações sociais nos níveis local, nacional, regional e internacional. Desde o seu surgimento como área disciplinar organizada, institucionalizada em universidades e centros de pesquisa nos Estados Unidos e na Europa há cerca de sessenta anos atrás, os estudos da paz têm procurado demonstrar que a paz não é apenas um ideal utópico, ou um estado contingente eventualmente alcançado entre guerras inevitáveis, mas é um objeto de pesquisa acadêmica a ser estudado em seus próprios méritos e a ser colocado em prática através de políticas concretas. Nesse sentido, os estudos da paz têm acumulado um vasto manancial de conhecimentos - conceitos, teorias, métodos e análises empíricas - que, em seu conjunto, fornecem indicações relevantes para a compreensão das causas dos conflitos violentos e das condições para a paz.

Há uma quantidade incontável de tópicos que alimentam a agenda dos estudos da paz, incluindo aspectos tão diversos quanto as causas da guerra; o problema das armas nucleares, do desarmamento e do controle de armas; as técnicas de resolução de conflitos; as operações de paz; a desmobilização, reconciliação e reconstrução pós-bélica; as migrações e os deslocamentos internos; a resistência não-violenta; as variadas formas de violência estrutural e cultural; a educação para a paz; as condições para uma paz positiva (redução das desigualdades econômicas, promoção da justiça social, redução da exploração e da opressão). O que esses poucos tópicos demonstram - e a lista poderia ser expandida para muito além desse horizonte - é que a agenda dos estudos da paz lida com algumas das questões mais urgentes e graves do nosso tempo, o que faz com que a relevância dessa área de pesquisa seja inquestionável.

Contudo, ainda que os estudos da paz se tenham institucionalizado em centenas de universidades e centros de pesquisa em todo o mundo (WIBERG, 2005), levando 
a um crescente número de estudantes solidamente treinados nessa área, tanto em nível de graduação quanto de pós-graduação, ainda é notável a marginalidade da disciplina no meio acadêmico brasileiro e a escassez de bibliografia produzida no Brasil dedicada às bases conceituais e questões metodológicas específicas dessa área de estudos. Esse aspecto parece surpreendente quando se considera o tradicional posicionamento externo do país em favor da resolução pacífica de conflitos, o seu crescente envolvimento nas operações de paz e as formas crônicas de violência direta, estrutural e cultural que hoje impactam as relações sociais nas zonas rurais e em grande parte das cidades brasileiras, colocando sérios desafios à construção de um ambiente de paz abrangente e sustentável no país. Embora esses aspectos remetam a questões típicas da agenda dos estudos da paz, dentro de seus variáveis níveis de análise, é notória a falta de ênfase e de institucionalização dessa disciplina nos currículos universitários brasileiros. Ainda que se deva notar um movimento embrionário de afirmação dessa área de pesquisa - traduzido sobretudo pelos esforços de criar uma Rede de Pesquisa em Paz, Conflitos e Estudos Críticos de Segurança (PCECS) e pela recente realização do I Encontro Brasileiro de Estudos para a Paz ${ }^{2}$ - não se pode deixar de ressaltar que muito esforço ainda precisa ser feito no sentido de tirar os estudos da paz da invisibilidade no contexto brasileiro.

O propósito deste artigo é traçar um panorama geral do percurso de consolidação dos estudos da paz como disciplina acadêmica, desde o seu nascimento na década de 1950 até a atualidade. Dentro desse propósito, o artigo procura destacar as origens e os elementos definidores centrais dos estudos da paz (primeira seção), os desenvolvimentos conceituais sobre a violência e a paz ocorridos na obra de Johan Galtung, considerado uma das referências centrais dessa área de estudos (segunda seção) e os principais desdobramentos e desafios dos estudos da paz na atualidade (terceira seção). Trata-se, portanto, de um texto introdutório que não propõe acrescentar conhecimentos originais e nem avançar o debate teórico além do já existente na disciplina, mas sim traçar um mapa geral dos seus contornos principais. Deve-se acrescentar, ainda, que a limitação imposta pela dimensão do artigo impõe uma abordagem seletiva, dentro da qual os desenvolvimentos conceituais da obra de Galtung são privilegiados, o que obviamente não esgota o amplo leque de temas, autores e pontos de vista que caracterizam a diversidade própria da área disciplinar aqui tratada. Mesmo dentro desses limites, considera-se

2 Ver: < http://pcecs.blogspot.com.br/ > . 
que o artigo oferece uma contribuição relevante não só para professores, estudantes e pesquisadores brasileiros ${ }^{3}$ interessados num panorama geral e introdutório sobre esta área de estudos, mas também para leitores que, mesmo sem vinculação acadêmica, atuam nas esferas governamental e não-governamental exercendo atividades relacionadas a ações humanitárias e intervenções em zonas de conflito e de violência endêmica.

\section{Elementos definidores centrais dos estudos da paz}

Embora o pensamento sobre a paz remonte à antiguidade, estando presente em diversas tradições religiosas, correntes filosóficas e vertentes do movimento pacifista, os estudos da paz - enquanto área disciplinar organizada, institucionalizada em universidades e centros de pesquisa, dotada de um corpo teórico próprio e de publicações e fóruns de discussão especializados - constituem um empreendimento relativamente novo. Com essas características institucionais, o nascimento dos estudos da paz ocorreu no final da década de 1950, nos Estados Unidos, embora sem se referir explicitamente ao termo "paz" no seu nome de batismo. O que se viu nesses momentos iniciais foi a emergência da expressão "pesquisa do conflito" (conflict research), empregada para designar a preocupação com a resolução pacífica dos conflitos em larga escala, fornecendo as balizas intelectuais que levaram acadêmicos como Kenneth Boulding, Herbert Kelman e Anatol Rapoport a criarem o Journal of Conflict Resolution em 1957 e o Center for Research on Conflict Resolution na Universidade de Michigan em 1959. Essa nascente agenda de pesquisa procurou buscar na revolução behaviorista - isto é, no movimento que projetava sobre as ciências sociais um aparato de validação científica inspirado nas ciências da natureza - o mesmo conjunto de ferramentas metodológicas que os realistas e estrategistas começavam a abraçar para se legitimarem como produtores de conhecimento científico (JCR, 1957).

Paralelamente a esses esforços, surgiu na Europa uma comunidade de pesquisadores com objetivos semelhantes. Porém, ao contrário da timidez com que a palavra "paz” aparecia na proposta dos colegas norte-americanos, os

3 Como professor de estudos da paz num curso de graduação, tenho constatado a demanda dos alunos por referências bibliográficas dessa área, escritas em português, que auxiliem os seus estudos. Considerando a possibilidade de que os estudos da paz se tornem mais visíveis e presentes nos currículos acadêmicos, em função dos recentes movimentos de institucionalização da disciplina no Brasil, é possível que essa demanda venha a aumentar, o que reforça a relevância aqui apresentada. 
pesquisadores europeus optaram por dar uma centralidade a esse termo, colocando o conceito de paz no núcleo do seu projeto intelectual e explicitando a palavra paz no título da sua atividade de pesquisa (peace research) e no nome dos seus institutos e departamentos acadêmicos. "Nós não temos medo da palavra 'paz'”, 4 afirmava Galtung no editorial de lançamento do Journal of Peace Research (JPR, 1964, p. 4), vinculado ao International Peace Research Institute Oslo (PRIO), criado em 1959 pelo mesmo acadêmico. Nesse editorial, Galtung propunha uma perspectiva metodológica mais flexível, ainda que se mantivesse firme no propósito de fazer da paz um objeto de estudo científico. Desse modo, mesmo defendendo um estatuto científico e a formulação de hipóteses e proposições gerais sobre a paz, o editorial inaugural do Journal of Peace Research sugeria que a consistência teórica, e não a confirmação empírica, deveria ser a preocupação central da pesquisa da paz (JPR, 1964, p. 4). Também relevante era o fato do editorial defender explicitamente que a apreciação ideológica poderia coexistir com a avaliação empírica, indicando uma posição menos rígida em relação à distinção entre fato e valor.

Nas origens desse projeto encontrava-se, portanto, a pretensão de desenvolver uma "ciência normativa" da paz, dentro da qual o rigor analítico e o respeito aos protocolos científicos de validação do conhecimento seriam temperados pela ideia de que a violência e a guerra têm um valor negativo - devendo, desse modo, ser rejeitadas ou, pelo menos, reduzidas - e que a produção teórica deveria contribuir, na prática, para a prevenção, a mitigação e a resolução dos conflitos violentos. Influenciada principalmente pela extraordinária capacidade de Galtung de diversificar suas abordagens conceituais e metodológicas, a designação dessa área de pesquisa evolui gradualmente para a expressão "estudos da paz", que passou a ser vista como um grande rótulo "guarda-chuva" destinado a abrigar não só o tipo de pesquisa neopositivista, fiel às origens behavioristas da pesquisa do conflito e da pesquisa da paz, mas também as abordagens mais reflexivas e críticas que foram incorporadas à disciplina com os conceitos de violência estrutural e cultural e com as influências construtivistas, críticas, pós-estruturalistas, feministas e pós-colonialistas introduzidas na disciplina a partir das décadas de 1980 e 1990. Dentro desse quadro passaram a conviver não só as agendas de pesquisa racionalistas, que até hoje guiam a orientação editorial de revistas tradicionais da área como o Journal of Conflict Resolution e o Journal of Peace Research, mas

4 Tradução livre do autor: "we are not afraid of the word 'peace'”. 
também as agendas mais críticas e reflexivistas que se fazem representar através de publicações acadêmicas surgidas posteriormente, tais como a Peace and Change e a Peace and Conflict Studies.

Dentro desse panorama, é importante notar que os estudos da paz assumiram, desde os seus momentos iniciais, uma identidade intelectual que se afirmava em oposição à corrente realista das Relações Internacionais e aos estudos estratégicos. Se a reflexão científica sobre a guerra e a paz após o fim da II Guerra Mundial constituía um monopólio da tradição realista e estratégica - onde a máxima si vis pacem, para bellum ${ }^{5}$ era auto reproduzida e auto reforçada como verdade fixa e universal -, a emergência da pesquisa do conflito e da pesquisa da paz nos anos 1950/1960 representou um desafio a essa concepção dominante. Ao assumirem que a paz não era um mero estado contingente alcançado por vitórias militares entre guerras inevitáveis, mas se definia por seus próprios méritos como um processo que podia ser construído através de políticas e intervenções orientadas primordialmente para afirmar a vida das pessoas e produzir um mundo melhor, mais igualitário e justo, livre das manifestações diretas e indiretas de violência, os estudos da paz propuseram uma ruptura com o pensamento tradicional, rejeitando a máxima "se queres a paz, prepara-te para a guerra” e colocando em seu lugar uma outra noção igualmente radical: se queres a paz, prepara-te para a paz (DUNN, 2005, p. 1). Portanto, a ambição de converter a paz em objeto de pesquisa acadêmica, sem que isto implicasse em negar o compromisso ético com a não-violência e com o propósito político da sua produção de conhecimento, sempre esteve presente no projeto intelectual dos estudos da paz e continua a ser um dos seus elementos definidores centrais.

Um segundo aspecto característico dos estudos da paz é a sua auto definição como área interdisciplinar de pesquisa. As duas grandes revistas científicas da área deixam claro, desde as suas fundações, esse elemento definidor. Conforme observam os editores do número inaugural do Journal of Conflict Resolution, os assuntos internacionais têm sido um domínio quase que exclusivo dos "historiadores e cientistas políticos", bem como de profissionais "como diplomatas e militares"; porém, continuam os editores, a prevenção da guerra requer que se vá além, trazendo para esse domínio os conhecimentos produzidos pelos sociólogos, psicólogos, educadores e pioneiros da ciência behaviorista (JCR, 1957). O editorial do primeiro número do Journal of Peace Research enfatiza,

5 "Se queres a paz, prepara-te para a guerra". 
igualmente, que a pesquisa da paz deve ser interdisciplinar (JPR, 1964, p. 4). Sobre essa característica, Galtung $(1985,2010)$ tem sido incansável em chamar a atenção para o fato de a paz ser um tópico demasiadamente complexo para ter a sua compreensão limitada a um quadro unidimensional de análise, geralmente orientado por disciplinas tradicionais como a história ou o direito internacional. Por essa razão, o autor considera que o conceito de paz deve ser permanentemente problematizado e que a pesquisa das condições para a paz deve "ligar o abismo existente entre o ‘tradicional' e o ‘moderno’ nas ciências sociais”6 (1985, p. 143), criando uma rede de pesquisadores de várias disciplinas (psicologia, sociologia, politologia, etc.), dentro da qual os pesquisadores da paz possam ser integrados. $\mathrm{O}$ autor vai mais longe ainda ao defender que, estimulados pelo diálogo e o intercâmbio intelectual dentro dessa rede interdisciplinar, os pesquisadores da paz caminhem para a transdisciplinaridade, ou seja, para uma crescente síntese e integração das perspectivas e abordagens dessas diversas disciplinas dentro das suas mentes individuais $(1985 ; 2010)$.

Um terceiro aspecto marcante dos estudos da paz é a sua característica multinível. Isto significa que os estudos da paz assumem o compromisso de olhar para os diversos níveis implicados na formação dos conflitos e nas condições para a paz, incluindo o individual, o comunitário, o estatal e o internacional. De fato, a tradicional centralidade do Estado e as convencionais fronteiras entre as esferas interna e interna que marcam as Relações Internacionais têm sido desafiadas pelos estudos da paz desde os seus momentos iniciais, devido ao caráter unidimensional e redutor que essas categorias impõem ao estudo dos conflitos e da paz. Ainda que os conflitos internacionais permaneçam entre os focos de preocupação relevantes dos estudos da paz, isto não implica em assumir que as únicas linhas que "cruzam a humanidade", criando obstáculos à integração e acentuando "a disposição para usar a violência”, sejam as fronteiras entre Estados; portanto, usar o Estado como único critério para definir o nível de análise nos estudos da paz parece redutor, uma vez que existem outras fronteiras igualmente importantes na formação e divisão de grupos (tais como linhas étnicas, religiosas, sociais ou econômicas), potencialmente capazes de produzir antagonismos que levam à violência (JPR, 1964).

Finalmente, o elemento que talvez defina os estudos da paz de uma forma mais particular seja a conjugação de uma epistemologia negativa e uma de epistemologia

6 Tradução livre do autor: "to bridge the gap between 'traditional' and 'modern' social sciences”. 
positiva na problematização do conceito de paz (RASMUSSEN, 2003). Desde o início de sua obra, Galtung traz no núcleo do seu projeto intelectual a noção de que os estudos da paz se desdobram em dois ramos de pesquisa, baseados em duas perspectivas epistemológicas distintas: uma negativa e outra positiva (JPR, 1964). Da primeira perspectiva, a paz é definida de uma forma estreita a partir do que ela não é ou do que ela nega: a violência física e a guerra. Essa noção, batizada por Galtung de "paz negativa”, traduz uma concepção minimalista de paz, restrita à ausência das manifestações diretas e aparentes da violência, que corresponde não só à perspectiva compartilhada pelo realismo nas Relações Internacionais e pelos estudos estratégicos, mas também às perspectivas do senso comum e dos movimentos pacifistas, que geralmente enxergam a paz através das lentes do ativismo antiguerra. Cabe à pesquisa da paz, dentro dessa epistemologia negativa, preocupar-se com as manifestações explícitas da violência, o que leva os pesquisadores a se dedicarem à compreensão das razões, causas, dinâmicas e formas de lidar com os efeitos diretos do conflito e da guerra. Dentro dessa moldura negativa da paz, os pesquisadores envolvem-se, por exemplo, com temas como diplomacia, negociação, mediação e outros instrumentos de gestão e resolução de conflitos; papel das organizações internacionais e do direito internacional na contenção da guerra; desarmamento e controle de armas, especialmente de armas nucleares, químicas e bacteriológicas; papel das organizações não-governamentais e dos mecanismos não-oficiais na resolução de conflitos; e outras formas de contenção ou supressão da violência física e aparente.

Da segunda perspectiva - e aqui está a grande novidade introduzida por Galtung - a paz define-se de uma forma maximalista a partir de tudo o que ela pode agregar: a mudança de mentalidades, o contato e o intercâmbio entre os grupos sociais, a educação, a pesquisa, a comunicação e o diálogo, as transformações sociais e econômicas, a cooperação institucional entre grupos e nações, e quaisquer outras propostas que se comprometam com “a integração humana” (JPR, 1964). Desse ângulo, a paz não se define pela mera ausência da violência física e direta - ainda que esta continue a ser uma das suas dimensões necessárias -, mas se expande para além desse horizonte, a fim de abranger qualquer iniciativa afirmativa que promova a integração humana. Essa segunda dimensão, que Galtung chama de "paz positiva", assume uma feição mais complexa e radical, indicando o compromisso com a construção de um sistema social global integrado, onde as mudanças sociais possam ser alcançadas através de meios não violentos. Dessa perspectiva positiva da paz, os pesquisadores envolvem-se, por exemplo, com 
temas relacionados aos direitos humanos; questões de gênero; desigualdades sociais e econômicas, desenvolvimento, redução da pobreza e combate à fome; bem-estar social; participação política; justiça social; transformações sociais não violentas; educação para a paz; reconstrução pós-conflito, reconciliação e justiça de transição; questões ambientais; pluralismo e diversidade cultural; diálogo e compreensão em todos os níveis, do interpessoal, ao intersocial, ao internacional. Dentro dessa dimensão positiva da paz, são cruciais os desenvolvimentos ocorridos na obra de Galtung, principalmente a partir do final da década de 1960, com o conceito de violência estrutural, e na passagem das décadas de 1980 pata 1990, com o conceito de violência cultural.

\section{Violência estrutural e os conceitos de peacekeeping, peacemaking e peacebuilding}

A introdução do conceito de violência estrutural na obra de Galtung e a sua articulação com o conceito de paz positiva ocorreu na passagem da década de 1960 para 1970, no contexto de um intenso debate interno fomentado pela crítica oriunda de jovens pesquisadores de orientação marxista, que acusavam a disciplina de se ter convertido num tipo de ciência aplicada, orientada para os interesses de "quem tem o poder de aplicá-la"7 (SCHMID, 1968, p. 229) e, como tal, uma fonte de conhecimento útil para o controle, a manipulação e a integração do sistema internacional pelos grupos dominantes. Da perspectiva desses jovens pesquisadores, os estudos da paz não passavam de numa espécie de pesquisa para a pacificação, produzindo um conhecimento orientado para a harmonização e o alívio imediato dos efeitos da violência, sem atentar para a necessidade de reestruturar radicalmente o sistema que estava na base dos antagonismos (DENCIK, 1970; STOHL; CHAMBERLAIN, 1972).

O conceito de violência estrutural proposto por Galtung (1969) responde, em grande medida, as críticas acima mencionadas. Definida como uma forma indireta de violência, cujas raízes estão na distribuição desigual de poder e de recursos nas sociedades ou entre as sociedades, a violência estrutural chama a atenção para um tipo de violência quase sempre latente, invisível ou disfarçada, que resulta das desigualdades sociais, das injustiças, da pobreza, da exploração e

7 Tradução livre do autor: "who has the power to apply it". 
da opressão. Desse modo, se o conceito de paz negativa se define pela ausência de violência direta, o conceito de paz positiva passa a ser definido como a ausência de violência estrutural e a ser articulado por Galtung através da noção de justiça social. A partir desse refinamento conceitual, a paz positiva - que na formulação original do autor ainda guardava uma dose de idealismo ao ser concebida genericamente como qualquer iniciativa voltada para a "integração humana” (JPR, 1964) - passa a ser concebida como a superação de todas as formas de desigualdades e injustiças sociais, dando à agenda de estudos da paz uma orientação mais reflexiva e emancipatória.

Essa dimensão estrutural da violência, reforçada por Galtung (1971) em sua teoria estrutural do imperialismo, traz para a teoria da paz as dinâmicas mundiais de exploração entre centro e periferia, bem como as disparidades de desenvolvimento dentro e entre nações, respondendo dessa forma à acusação de seus críticos mais radicais de que os estudos da paz, até então obcecados pelas dinâmicas estratégicas da Guerra Fria, pactuavam em grande medida ou pelo menos não se preocupavam na dimensão necessária - com a estrutura dominante de poder e com a lógica de autorreprodução da violência implicada nessa ordem dominante. Essa reorientação na teoria da paz e a sua conexão com a teoria do conflito e a teoria do desenvolvimento fornecem elementos essenciais para alimentar as reflexões de Galtung, desenvolvidas em meados da década de 1970, sobre três formas possíveis de intervenção em nome da paz no contexto de conflitos violentos: peacekeeping, peacemaking e peacebuilding (GALTUNG, 1976).

Se hoje os termos peacekeeping, peacemaking e peacebuilding pertencem ao léxico usual das chamadas operações de paz da Organização das Nações Unidas (ONU), é importante salientar que esses conceitos não existem na Carta das Nações Unidas. Na verdade, até a discussão proposta por Galtung em meados dos anos 1970, apenas as práticas tradicionalmente associadas ao termo peacekeeping (manutenção da paz) tinham alguma notoriedade, desde que Dag Hammarskjöld, Secretário-Geral da ONU, e Lester Pearson, Secretário de Assuntos Externos do governo canadense, tinham definido os princípios básicos que guiariam a atuação da Força de Emergência das Nações Unidas (UNEF I), criada para intervir em 1956 na chamada Crise de Suez (ONU, 1956). Pode-se dizer, portanto, que o termo peacekeeping tornou-se conhecido mais pelas práticas de intervenção realizadas sob mandato da ONU durante a Guerra Fria, do que por algum debate teórico ou alguma definição doutrinária nos documentos de alto nível daquela Organização. A discussão proposta por Galtung representa, dentro desse quadro, uma tentativa 
pioneira de teorizar as operações de paz e de propor um léxico apropriado às diferentes abordagens à paz, que só serão incorporadas à doutrina de intervenções da ONU cerca de quinze anos depois.

Em seu texto, Galtung destaca que o propósito do peacekeeping é "manter a paz” entre as partes em conflito através da interposição de uma terceira parte entre elas; isto significa, segundo o autor, que essa abordagem tem duas características definidoras centrais: ela é "dissociativa” (pois pressupõe que os antagonistas sejam mantidos segregados geograficamente, sob a ameaça de punição caso transgridam os limites dessa separação), e reflete uma concepção negativa da paz (pois limita-se à manutenção da ausência de violência direta). A segunda categoria o peacemaking ("restabelecimento da paz") - confunde-se com a abordagem de resolução de conflitos e reflete os esforços diplomáticos de negociação de um acordo que tenha um efeito apaziguador e possa ser ratificado pelas partes em conflito. Esses esforços de negociação de um acordo podem surgir entre as próprias partes em conflito ou com a ajuda de uma terceira parte. Ainda que Galtung considere essa abordagem importante e necessária, suas limitações também são relevantes. Em primeiro lugar, o seu foco também se limita à interrupção da violência direta, refletindo, portanto, uma concepção negativa da paz. Em segundo lugar, e talvez mais importante, o peacemaking depende do empenho e do comprometimento das lideranças de cada parte; como tal, é uma abordagem elitista e sujeita a flutuações de opiniões e retrocessos em função da eventual mudança dos atores-chave durante as negociações ou no período posterior ao acordo negociado. Também problemáticos são os casos, bastante frequentes segundo Galtung, de acordos produzidos sob pressão de uma terceira-parte que não refletem, necessariamente, as posições das partes em conflito. Isso mostra que as ações de peacemaking podem não ser suficientes para sustentar um sistema de paz, o que leva à necessidade de uma terceira abordagem - o peacebuilding ("construção" ou "consolidação" da paz) - que olhe de uma forma mais profunda para as fontes da violência estrutural e procure superá-las através da construção de uma paz positiva.

Essa terceira abordagem, de caráter "associativo" (contrário ao perfil dissociativo do peacekeeping), tem por propósito agregar as partes dentro de uma estrutura de paz que substitua a estrutura de violência que está na base do conflito. Nesse sentido, o peacebuilding requer que a estrutura que produz a violência seja identificada e substituída por uma estrutura alternativa de paz, mais igualitária, justa e livre de dominação, repressão e exploração - o que leva, segundo Galtung, a uma preocupação mais radical com medidas de desenvolvimento social. Desse 
ponto de vista, afirma o autor, o peacebuilding vai além da abordagem dissociativa do peacekeeping e dos esforços diplomáticos ad hoc para resolver as manifestações superficiais do conflito que caracterizam o peacemaking. O peacebuilding envolve uma estrutura social mais horizontalizada, portanto menos hierarquizada, onde as disparidades de desenvolvimento entre os indivíduos, classes, grupos, nações e regiões sejam reduzidas. Desse modo, as condições para uma paz positiva podem ser alcançadas: "assim como um corpo saudável pode produzir os seus próprios anticorpos sem a necessidade da administração ad hoc de medicamentos”, destaca Galtung recorrendo às suas usuais metáforas médicas, um "corpo mundial saudável” é capaz de produzir seus próprios "anticorpos" contra a violência; para isto, "é preciso encontrar estruturas que removam as causas da guerra e ofereçam alternativas às guerras em situações onde elas possam surgir”" (1976, p. 297-298, itálico no original). Na base das reflexões de Galtung, portanto, está a noção de que só as transformações estruturais e a justiça social promovidas pelo peacebuilding são capazes de produzir os "anticorpos" contra a violência, o que sugere uma ideia de paz autossustentável que só será incorporada ao léxico internacional mais de uma década depois, após o fim da Guerra Fria, com a revitalização do papel da ONU na construção de uma ordem mundial mais pacífica.

\section{Desdobramentos e desafios dos estudos da paz no pós-Guerra Fria}

No início dos anos 1990, Galtung dá mais um salto na sua teoria da paz. O autor observa que alguns aspectos próprios da esfera simbólica da existência humana (religião, ideologia, arte, linguagem, ciência, etc.) podem reforçar as formas diretas e estruturais de violência, legitimando-as ou fazendo com que elas sejam percebidas como corretas - ou pelo menos pareçam não erradas - aos olhos da sociedade (GALTUNG, 1990). Essas manifestações simbólicas, que Galtung chama de violência cultural, atuam através de mecanismos sutis e indiretos, exercendo uma função importante na construção de identidades coletivas que podem contribuir para a estabilização de determinadas ordens sociais onde formas diretas e estruturais de violência são vistas como "normais" (1990). O racismo, o machismo, as superstições, os fundamentalismos religiosos, os nacionalismos, o militarismo, as ideologias, o colonialismo, a meritocracia, as etnias e outras

8 Tradução livre do autor: "structures must be found that remove causes of wars and offer alternatives to war in situations where wars might occur”. 
construções simbólicas geralmente fundadas em relações binárias do tipo bom/ mau, escolhido/não escolhido, superior/inferior, amigo/inimigo ou racional/ emocional ilustram esse tipo de violência cultural, servindo como mecanismo de justificação ou legitimação de outras formas de violência direta e estrutural.

Com essa nova categoria conceitual, Galtung completa o que ele batiza de "triângulo da violência” (1996), onde num dos vértices está a violência direta e nos outros dois estão as formas indiretas de violência: a estrutural e a cultural. Projetando esse triângulo sobre o conceito da paz, Galtung chega a uma equação complexa, onde a paz negativa se define pela eliminação da violência direta e a paz positiva pela eliminação das duas formas de violência indireta: a estrutural e a cultural. O ponto de chegada dessa longa trajetória é uma concepção abrangente de paz que corresponde ao somatório da paz negativa com a paz positiva, sendo a última o somatório da paz estrutural com a paz cultural (figura 1).

Figura 1: Triângulos da Violência e da Paz Direta, Estrutural e Cultural de Galtung
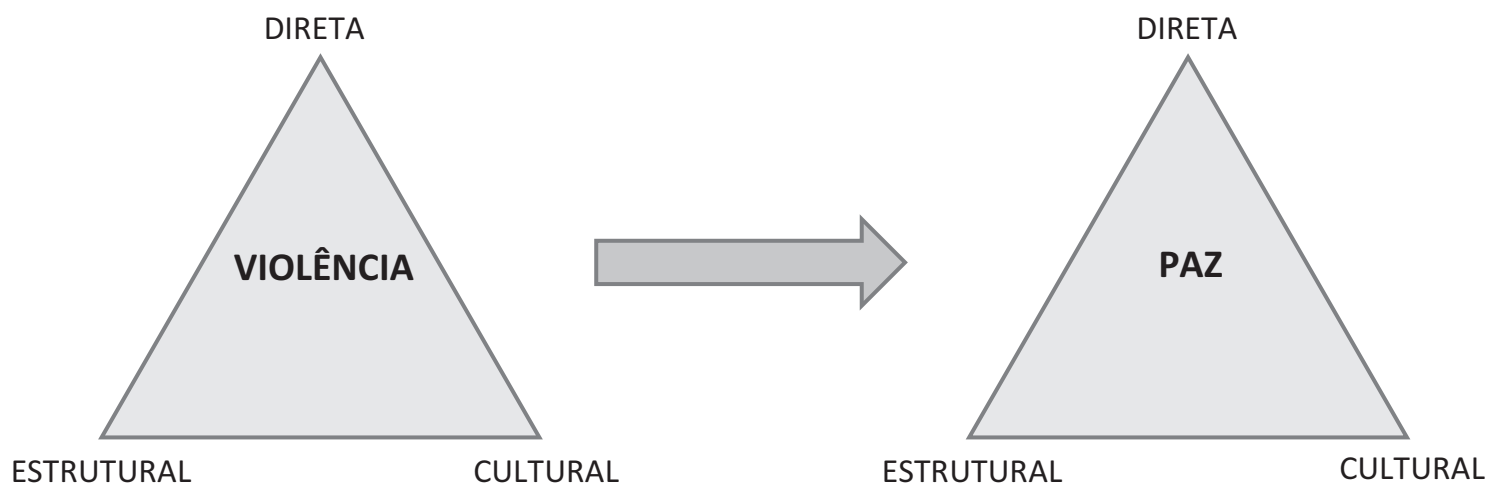

$P A Z=P n+P p$

Onde: Pn é a paz negativa (paz direta) e Pp é a paz positiva (paz estrutural + paz cultural)

Fonte: GALTUNG, 1996.

Esses últimos desenvolvimentos na obra de Galtung surgem num contexto fortemente influenciado pela ideia de uma ordem mundial alternativa e pelas questões de identidade que impactam o estudo da política internacional no fim da Guerra Fria. Dentro desse quadro, as preocupações com a paz e a segurança reorientam-se para questões inteiramente novas. Perante um número crescente de conflitos civis localizados na periferia do centro desenvolvido do sistema (Ex-Iugoslávia, Camboja, Somália, Ruanda, Serra Leoa, Libéria, República Democrática do Congo, Sudão, etc.), os estudos das causas da guerra e das condições para a paz emergem dentro de novos parâmetros. Ao olhar para esses conflitos, rotulados 
de "novas guerras" (KALDOR, 1999; KEEN, 1998; RENO, 1999; DUFFIELD, 2001) ou de conflitos "intratáveis" ou "persistentes" (AZAR, 1990, 2003), diversos autores observam características que não mais se ajustam às dinâmicas sistêmicas da competição bipolar e nem ao tipo de guerra convencional entre Estados marcado pelo enfrentamento de forças armadas profissionalizadas para atingir objetivos políticos claramente definidos. Nessa "nova" conflitualidade, onde se observam uma mistura complexa de atores governamentais e não-governamentais, agendas econômicas oficiais e paralelas, degradação ambiental e escassez de recursos naturais, bem como profundas divisões étnicas, culturais e religiosas, o ponto crucial destacado pelos autores é que os conflitos contemporâneos se prolongam indefinidamente, sem um ciclo claro de gênese, progressão, redução e terminação da violência, tornando-se pouco permeáveis aos esforços formais de resolução de conflitos e consolidação da paz (AZAR, 1990, 2003; COLLIER; HOEFFLER, 1998; BERDAL; MALONE, 2000; BALLENTINE; SHERMAN, 2003; PUGH; COOPER, 2004).

Perante esse quadro de conflitos persistentes e intratáveis, em cujas raízes estão graves desequilíbrios estruturais (violência estrutural) e questões étnicas e religiosas que moldam as identidades dos grupos em conflito (violência cultural), é importante notar os desenvolvimentos doutrinários e institucionais ocorridos no âmbito da ONU, que trazem os estudos da paz para o centro do seu modelo de intervenções e influenciam significativamente a expansão da sua doutrina de operações de paz nos anos 1990 e 2000. Na "Agenda para a Paz" (ONU, 1992), onde o então Secretário-Geral Boutros-Ghali defende o envolvimento mais ativo da comunidade internacional na prevenção e na gestão dos conflitos violentos, as abordagens à paz definidas no trabalho de Galtung em meados da década de 1970, já comentadas na seção anterior, são trazidas para o centro das práticas de intervenção da ONU. Nesse documento, Boutros-Ghali propõe quatro tipos de operações que, se aplicados em conjunto, podem prevenir o conflito antes que ele se converta em violência (preventive diplomacy), parar o conflito após a violência ter sido deflagrada (peacemaking), manter a paz após um acordo ter sido alcançado (peacekeeping) e consolidar a paz na fase pós-conflito, através das mudanças estruturais necessárias ao bem-estar das pessoas e à redução das desigualdades sociais, contribuindo assim para evitar novas ondas de violência no futuro (peacebuilding).

Nesse contexto, há um crescimento significativo na quantidade de operações de paz a partir dos anos 1990, acompanhado de mudanças fundamentais na sua composição e nas suas funções. No que se refere à composição, as operações 
de paz passam a incorporar atores tão diversos quanto militares, policiais, diplomatas, agentes humanitários, organizações não-governamentais, agências de desenvolvimento e empresas privadas de segurança. Para além dessa diversidade de composição, as funções desempenhadas pelas operações de paz também se multiplicam, passando a abranger um amplo leque de atividades de natureza militar, política e humanitária. Na base dessa expansão do modelo de intervenções da ONU encontra-se subjacente o compromisso de mobilizar esforços não só para exercer uma influência coerciva sobre os beligerantes no sentido de se produzir uma paz negativa, mas também para criar as condições para uma paz positiva através de medidas econômicas, culturais, políticas, técnicas, humanitárias e legais capazes de promover as transformações sociais necessárias à consolidação da paz (RAMSBOTHAM; WOODHOUSE; MIALL, 2008). Se essa cooptação dos estudos da paz pela ONU indica, por um lado, a realização política do ideal normativo da disciplina, colocando a pesquisa da paz dentro do que se pode chamar de "policy-oriented mainstream" (PUREZA; CRAVO, 2005, p. 10), não se pode deixar de notar, por outro lado, que os desenvolvimentos subsequentes, inclusive através da crescente adoção de um aparato militar mais robusto e da autorização de operações sob o capítulo VII da Carta da ONU, com mandato para o uso da força, caminham para um modelo hegemônico de pacificação de periferias instáveis que traem, de forma contundente, os propósitos transformativos e emancipatórios originais dos estudos da paz, especialmente de sua agenda dedicada à paz positiva.

Em função desse quadro de conflitos persistentes e intratáveis e dos rumos tomados pelo modelo de intervenções da ONU a partir dos anos 1990, as questões relacionadas à transformação de conflitos e à consolidação da paz emergem como o núcleo de preocupação central da agenda dos estudos da paz nas últimas duas décadas. Na base da ideia de transformação de conflitos está a percepção de que os conflitos persistentes não podem ser "resolvidos" ou "solucionados", mas sim "transformados". Embora essa noção já esteja subjacente na obra de Galtung com a ideia de que as violências estrutural e cultural precisam ser transformadas para se alcançar uma paz positiva, é apenas em meados da década de 1990, em seu livro Peace by Peacefull Means, que a sua teoria da paz se conecta explicitamente à noção de transformação de conflitos. Nessa obra, o autor propõe que o conceito de paz seja definido não só em função da violência, mas também em função do conflito; a partir dessa proposta, Galtung chega à seguinte definição: " $a$ paz é a transformação do conflito de forma criativa e não violenta"9 (1996, p. 9, itálico

9 Tradução livre do autor: "peace is nonviolent and creative conflict transformation". 
no original). Com isto, o autor pretende chamar a atenção para a necessidade de transformar as atitudes, comportamentos e contradições que estão na base dos conflitos sociais, a fim de que uma paz abrangente e sustentável seja alcançada. Na base da transformação de conflitos está, portanto, a ideia de que os conflitos são inerentes às relações sociais e, como tal, não podem ser negados e nem sufocados, mas sim transformados de forma criativa e não violenta através de um processo complexo e de longo prazo (1996).

Ainda que se deva destacar a pluralidade das abordagens e pontos de vistas dos autores que se dedicam, desde os anos 1990, à reflexão sobre a transformação de conflitos, uma forma simplificada de síntese desse debate é situá-lo em termos de uma crítica à noção de resolução de conflitos. Conforme destaca Raimo Väyrynen (1999), as receitas de pronto uso e a busca de resultados de curto impacto que geralmente regem as teorias tradicionais de resolução de conflitos negligenciam a complexidade estrutural das situações de conflito e as profundas incompatibilidades de interesses e valores entre os atores envolvidos. Por essa razão, as abordagens que tentam controlar ou eliminar a violência direta resultam em esforços inúteis, a menos que a necessidade de transformação do contexto social e cultural do conflito seja também considerada (VÄYRYNEN, 1991). Dessa perspectiva, a questão chave na transformação de conflitos é identificar as raízes da violência e avaliar a maleabilidade dessas raízes, a fim de que os esforços de transformação possam ser bem-sucedidos (VÄYRYNEN, 1999).

John P. Lederach concorda com essa perspectiva transformativa ao defender a necessidade de se ir ao "epicentro" do conflito (isto é, às suas raízes principais e profundas) para que uma paz sustentável seja alcançada (2003). Embora esse autor não desconsidere a importância de medidas de resolução dirigidas às expressões visíveis da violência, é o foco no epicentro que permite identificar e propor medidas transformativas, voltadas para a reestruturação das relações de violência a longo prazo (2003). Segundo Lederach, essa reestruturação pode ser concretizada não só através da educação, ativismo não violento e mediação (1995), mas também através de uma estratégia de intervenção multidimensional, multinível e multitemporal que valorize a participação de um amplo leque de atores, externos e locais, com especial destaque para os atores não oficiais, membros da sociedade civil e vozes normalmente marginalizadas no contexto do conflito (1997).

É importante notar que essa perspectiva transformativa tem sido integrada a outros debates nascentes na disciplina. Uma dessas agendas tem procurado ir além da reflexão sobre as novas guerras, a fim de destacar o que alguns acadêmicos 
têm chamado de "novíssimas guerras" (MOURA, 2010), "novo urbanismo militar" (GRAHAN, 2010), "guerras urbanas" (BEALL, 2006), "guerras de favelas" (RODGERS, 2009), "cidades frágeis" e "cidades falhadas" (BEALL; GOODFELLOW; RODGERS, 2013; LIOTTA; MISKEL, 2012; MUGGAH, 2014). Essa bibliografia compõe um amplo mosaico de abordagens que, resguardadas as suas particularidades (algumas mais críticas e emancipatórias, outras mais conservadoras e estratégicas), giram em torno de um eixo comum: a intensificação da violência armada e o crescente processo de militarização das grandes metrópoles. Dentro de um quadro de relativo declínio das guerras entre Estados, o que parece crucial nessa bibliografia, do ponto de vista da transformação de conflitos, é a constatação de uma escala cada vez mais microscópica de conflitos violentos, concentrados em microterritórios dos grandes centros urbanos, inclusive em contextos nacionais de paz aparente e formal (MOURA, 2010).

Nessa agenda, o trabalho de Tatiana Moura (2010) assume um viés particularmente crítico e reflexivo ao examinar a escala microssocial de conflitos de uma perspectiva feminista. Com base na análise da violência armada nas grandes cidades, particularmente no Rio de Janeiro, a autora observa formas diretas e indiretas de violência (estrutural e cultural) que perpetuam sistemas de poder em microescala e submetem as populações locais, principalmente as mulheres e crianças, a uma espiral de inseguranças. Embora essas dinâmicas de violência produzam níveis elevados de tensão, Moura destaca que elas são negligenciadas dentro das teorias, narrativas e práticas dominantes de construção da paz. O que parece crucial nesse debate, do ponto de vista da transformação de conflitos, é a necessidade, já enfatizada por Lederach, de uma abordagem multinível que dê visibilidade às vozes geralmente marginalizadas nos contextos microssociais dos conflitos. Ao chamar a atenção para a "hiperconcentração" de violência urbana, que se dilui e se oculta num contexto de paz institucional e formal, Moura lança como desafio a necessidade de se desvendar a construção de identidades (feminilidades e masculinidades) que legitimam e perpetuam essas "novíssimas" dinâmicas da violência armada. Só assim será possível identificar formas alternativas e não violentas de prevenção e transformação que produzam "novíssimas pazes" nesses contextos "invisíveis" e "silenciados" de violência em microescala (MOURA, 2010).

Outro debate que começa a ser articulado com a reflexão sobre transformação de conflitos resulta da recente revitalização do pensamento sobre a ação nãoviolenta. Sob o impacto das revoluções pacíficas da chamada "Primavera 
Árabe", parte da atual agenda dos estudos da paz tem retornado aos métodos de protesto, não-cooperação e intervenção pacífica. Essa temática, que já havia inspirado referências clássicas dos estudos da paz (GALTUNG, 1959; SHARP, 1973; BOULDING, 1999), tem sido trazida, principalmente por Véronique Dudouet (2008; 2015), para um quadro de reflexão sobre a transformação de conflitos em situações onde se observam relações de poder assimétricas, especialmente nos estágios iniciais de conflitos latentes enraizados em violência estrutural. Segundo essa autora, o potencial de "empoderamento" popular, de pressão sobre o oponente e de obtenção da simpatia de terceiras-partes torna a ação não violenta um instrumento útil nas mãos de comunidades marginalizadas e desprivilegiadas na busca de uma posição mais fortalecida, a partir da qual o caminho para a negociação de concessões pode se tornar propício (2008).

Considerando a capacidade da ação não violenta para transformar as relações de poder e transformar as identidades através da persuasão, Dudouet sugere uma combinação de princípios e de preocupações pragmáticas que pode fazer da ação não-violenta uma ferramenta importante de ação política capaz de atuar através de um duplo processo de diálogo e resistência: diálogo com o oponente mais poderoso (com o objetivo de persuadi-lo sobre a justiça e a legitimidade das causas defendidas pelas partes mais fracas) e resistência às estruturas injustas de poder (com o objetivo de pressionar por mudanças sociais e políticas). Ao estudar o conflito entre Israel e Palestina, Dudouet (2008) destaca, porém, que as condições para a operação desse processo dialético da não violência tendem a ser dificultadas nos estágios mais avançados do conflito ou em situações que mostram um alto grau de polarização entre grupos oponentes quanto a aspetos não negociáveis. Nesses casos mais extremos, a autora considera que a ação não violenta, isoladamente, pode não ser efetiva na prevenção de mal-entendidos e na superação dos ressentimentos entre as partes, o que sugere a necessidade de integrar a ação não-violenta dentro de uma estratégia transformativa de longo prazo que inclua múltiplas formas de intervenção, tais como a negociação, a mediação, a intervenção de terceiras-parte e outras medidas de peacemaking e peacebuilding.

Ao olhar para esse foco dos estudos da paz na transformação de conflitos e na consolidação da paz, alguns autores têm alertado, porém, para o risco de que a ideia de transformação das raízes do conflito e busca de mudanças sociais acabe resultando em projetos de engenharia social (VÄYRYNEN, 1999). Richmond (2007a) concorda com esse alerta ao criticar o grande projeto de engenharia social que se encontra subjacente à chamada "paz liberal". Segundo o autor, essa 
noção de paz, consolidada no contexto do liberalismo triunfante do pós-Guerra Fria, tem submetido as formas de intervenção e os modelos de transformação de conflitos a uma espécie de consenso sobre peacebuilding que leva à exportação do modelo institucional do Estado ocidental liberal para as zonas de conflito (2007a). Dentro desse consenso, até mesmo as perspectivas emancipatórias comprometidas com a transformação social acabam cooptadas por projetos de engenharia social, guiadas pela ideia de que transformar as raízes estruturais e culturais da violência é sinônimo de criar instituições liberais - democracia, estado de direito, direitos humanos, desenvolvimento e livre mercado (2007a). Dentro desse processo, geralmente imposto de "cima para baixo" e conduzido por agentes externos, as pessoas e as dinâmicas locais são apagadas e a almejada transformação das raízes estruturais e culturais do conflito acaba por criar uma "paz virtual" não compartilhada pelas comunidades locais, que atende mais aos objetivos de segurança das Organizações e Estados interventores do que às necessidades concretas de segurança e desenvolvimento em microescala das populações mais vitimadas pela violência (2007a).

Não se pode deixar de notar que esse projeto intervencionista se tem tornado ainda mais intrusivo e violento a partir dos ataques terroristas de setembro de 2001, quando o uso da força militar pelas potências ocidentais em típicas operações de guerra passou a ser mesclado com um projeto liberal de construção de Estado nos chamados "Estados párias" como receita de combate ao terrorismo. Estrategicamente inseridas na chamada "guerra contra o terror" (Afeganistão e Iraque) ou normativamente justificadas com base no princípio da "responsabilidade de proteger" (Líbia), essas intervenções não poupam esforços no uso da força, instituindo uma forma militarizada de ação que defende a emancipação das populações civis, a fim de evitar que elas se tornem vítimas de ditadores e grupos perigosos, ao mesmo tempo que admite a morte dessas mesmas populações como um efeito colateral da intervenção (DILLON; REID, 2009). O que se nota com base nesses desenvolvimentos é que a paz, ao ser incorporada como conceito-chave nas doutrinas e práticas de intervenção internacional no pós-Guerra Fria, convertese, segundo os críticos da paz liberal, num novo mecanismo de opressão social, numa nova forma de dominação e controle das sociedades alvos de intervenção (PUREZA; CRAVO, 2005).

Em função desses desenvolvimentos, um dos impactos mais radicais nos desdobramentos contemporâneos dos estudos da paz talvez sejam ilustrados pelo deslocamento do eixo de reflexão do conceito de "paz" para o conceito 
de "segurança" ocorrido na agenda de diversos pesquisadores anteriormente vinculados aos estudos da paz. Para esse grupo de pesquisadores, muitos deles oriundos do Instituto de Pesquisa da Paz de Copenhague (Copenhagen Peace Research Institute - COPRI), extinto em 2003 e incorporado ao Instituto Dinamarquês para Estudos Internacionais, o conceito de segurança, em vez do conceito de paz, passou a ser a categoria-chave através da qual a crítica ao mainstream dos estudos internacionais pode ser conduzida no pós-Guerra Fria (BUZAN; HANSEN 2009, p. 135; WAEVER 2004). A esse respeito, as palavras de Ole Waever são contundentes: se os estudos da paz representaram o grande desafio crítico aos estudos estratégicos durante a Guerra Fria, recusando-se a aceitar a política oficial do Ocidente quanto às questões de segurança, hoje as coisas inverteram-se e a paz tornou-se um dos conceitos dominantes na formulação de políticas no mundo ocidental, servindo inclusive para justificar intervenções violentas; desse modo, se por um lado "a segurança é potencialmente o nome de uma agenda radical, subversiva”10 (e aqui Waever está se referindo, obviamente, à emergência dos estudos críticos de segurança, que desde o fim da Guerra Fria se tem nutrido das perspectivas radicais pós-positivistas), por outro lado a pesquisa da paz pode ser considerada datada porque a paz se tornou tão doutrinária que o conceito deixou de ser "intelectualmente interessante" (2004, p. 63).

Se as palavras do parágrafo acima refletem com propriedade a expansão do conceito de segurança como forma de desafiar as perspectivas realistas e estratégicas no pós-Guerra Fria, elas soam injustas com os esforços de diversos estudiosos da paz no sentido de incorporar em suas agendas uma orientação igualmente radical e emancipatória. Adotando uma perspectiva reflexiva e defendendo uma pluralidade metodológica aberta às influências da teoria crítica, do pós-estruturalismo, do pós-colonialismo, do feminismo (CHANDLER, 2010; DILLON; REID, 2009; DUFFIELD, 2001, 2007, 2010; JABRI, 2013; MAC GINTY 2008; MOURA, 2010; PORTER, 2007; PUGH 2005; PUREZA, 2011; RICHMOND 2007a, 2011a, 2011b; RICHMOND; MITCHELL 2012; TURNER, 2012), ou defendendo uma perspectiva estética voltada para o papel da emoção e das expressões artísticas na construção da paz (BLEIKER, 2009; RICHMOND, 2007b; HUTCHISON; BLEIKER, 2008), esses trabalhos têm contribuído para colocar os estudos da paz em dia com os desenvolvimentos epistemológicos e metodológicos mais recentes e para reforçar a radicalidade do programa de paz positiva originalmente vislumbrado na obra de Galtung.

10 Tradução livre do autor: "security is potentially the name of a radical, subversive agenda”. 


\section{Conclusões}

Os estudos da paz desenvolveram-se em torno de duas grandes orientações. De um lado, a disciplina assumiu um perfil conservador, voltado para as explanações mais convencionais e minimalistas da paz, focado nas manifestações diretas da violência e na solução dos problemas específicos gerados pela guerra propriamente dita. Os resultados alcançados por essa linha mais conservadora, predominantemente neopositivista em sua abordagem metodológica, não podem ser negligenciados: os estudos da paz estão hoje institucionalizados em centenas de universidades e centros de investigação em todo o mundo e o manancial acumulado de pesquisas rigorosas, detalhadas, documentadas e empiricamente testadas sobre as causas dos conflitos e das guerras e sobre a eficácia das técnicas e métodos de resolução de conflitos podem ser escrutinadas em mais de sessenta volumes do Jornal of Conflict Resolution e mais de cinquenta volumes do Journal of Peace Research - revistas hoje situadas entre as publicações científicas com maior fator de impacto no campo das Relações Internacionais.

Ainda que seja importante reconhecer esse o mérito, é igualmente relevante notar que, para confrontar as questões estruturais e culturais que estão nas raízes mais profundas do conflito e da paz, nem sempre visíveis e mensuráveis pelos protocolos objetivos neopositivistas, é preciso estimular o desenvolvimento da segunda orientação da disciplina, mais radical, maximalista, crítica e reflexiva, voltada para uma visão transformadora e emancipatória do mundo. Se a consolidação e institucionalização dos estudos da paz como disciplina rigorosa passou pela necessidade de sua afirmação como ciência empirista fundamentalmente voltada para as questões técnicas colocadas no campo da resolução de conflitos e reconstrução pós-bélica, a longa trajetória intelectual de Galtung e os desafios transformativos colocados pela conflitualidade contemporânea reforçam a necessidade de um constante trabalho de conceptualização da paz e de busca de novas perspectivas que sejam capazes de penetrar nas camadas mais profundas, nem sempre visíveis, de um mundo marcado por conflitos cada vez mais complexos, multidimensionais, multiníveis e, portanto, diferentes do conflito macrossocial entre as superpotências que marcou o nascimento dos estudos da paz. Nesse sentido, a abertura da disciplina para a pluralidade epistemológica e metodológica, incorporando as viradas construtivista, crítica, pós-estruturalista, pós-colonialista, feminista e estética que têm impactado o estudo da política internacional, bem como para as novas formas através das quais a violência e os conflitos se manifestam no 
mundo contemporâneo, deve ser vista como uma via essencial para que a paz se mantenha como um conceito intelectualmente desafiador, fiel à radicalidade que os estudos da paz trazem no seu DNA desde o seu nascimento.

\section{Referências}

AZAR, Edward. The Management of Protracted Social Conflict: Theory \& Cases. Aldershot: Dartmouth, 1990.

AZAR, Edward. Protracted Social Conflicts and Second Track Diplomacy. In DAVIES, J.; KAUFMAN, E. (Eds.) Second Track/ Citizens' Diplomacy: Concepts and Techniques for Conflict Transformation. Oxford: Rowman \& Littlefield, 2003, Capítulo 1, p. 15-30.

BALLENTINE, Karen; SHERMAN, Jake. The political Economy of Armed Conflict: beyond greed and grievance. London: Lynne Rienner, 2003.

BEALL, Jo. Cities, Terrorism and Development. Journal of International Development, v.18, n. 1, 2006, p. 105-120.

BEALL, Jo; GOODFELLOW, Tom; RODGERS, Dennis. Cities and conflict in fragile states in the developing world. Urban Studies, v.50, n.15, 2013, p. 3009-3115.

BERDAL, Mats; MALONE, David M. (Eds.). Greed and Grievance: economic agendas in civil wars. Boulder: Lynne Rienner, 2000.

BLEIKER, Roland. Aesthetics and World Politics. New York: Palgrave Macmillan, 2009.

BOULDING, Keneth. Nonviolence and Power in the Twentieth Century. In ZUNES, S.; KURTZ, L. B.; ASHER, S. B. (Eds.) Nonviolent Social Movements: A Geographical Perspective. Oxford: Blackwell Publishing, 1999, Capítulo 1, p. 9-17.

BUZAN, Barry; HANSEN, Lene. The Evolution of International Security Studies. Cambridge: Cambridge University Press, 2009.

CHANDLER, David. International Statebuilding: The Rise of Post-Liberal Governance. London: Routledge, 2010.

COLLIER, Paul; HOEFFLER, Anke. On Economic Causes of Civil War. Oxford Economic Papers, v. 50, 1998, p. 563-573.

DENCIK, Lars. Peace Research: Pacification or Revolution? Notes on an Intra-peace Research Conflict. In International Peace Research Association Proceedings, 3rd General conference, v. 1, 1970, p. 79.

DILLON, Michael; REID, Julian. The Liberal way of War: Killing to make Life Live. Londres: Routledge, 2009.

DUDOUET, Véronique. Nonviolent Resistance and Conflict Transformation in Power Asymmetries. Berlin: Berghof Research Center for Constructive Conflict Management, 2008. 
DUDOUET, Véronique. Civil Resistance and Conflict Transformation: Transitions from Armed to Nonviolent Struggle. Abingdon: Routledge, 2015.

DUFFIELD, Mark. Global Governance and the New Wars: The Merging of Development and Security. London: Zed Books, 2001.

DUFFIELD, Mark. Development, Security and Unending War: Governing the World of Peoples. Cambridge: Polity Press, 2007.

DUFFIELD, Mark. The Liberal Way of Development and the Development-Security Impasse: Exploring the Global Life-Chance Divide. Security Dialogue, v. 41, n. 1, 2010, p. 53-76.

DUNN, David J. The First Years of Peace Research: A Survey and Interpretation. Aldershot: Ashgate, 2005.

GALTUNG, Johan. Pacifism from a Sociological Point of View. Journal of Conflict Resolution, v. 3, n. 1, 1959, p. 67-84.

GALTUNG, Johan. Violence, Peace and Peace Research. Journal of Peace Research, v. 6, n. 3, 1969, p. 167-191.

GALTUNG, Johan. A Structural Theory of Imperialism. Journal of Peace Research, v. 8, n. 2, 1971, p. 81-117.

GALTUNG, Johan. Three Approaches to Peace: Peacekeeping, Peacemaking and Peacebuilding. In GALTUNG, Johan (Ed.) Essays in peace research, vol. 2. Copenhagen: Ejlers, 1976, Capítulo II, p. 282-304.

GALTUNG, Johan. Twenty-Five Years of Peace Research: Ten Challenges and Some Responses. Journal of Peace Research, v. 22, n. 2, 1985, p. 141-158.

GALTUNG, Johan. Cultural Violence. Journal of Peace Research, v. 27, n. 3, 1990, p. 291-305. GALTUNG, Johan. Peace by Peacefull Means. London: SAGE, 1996.

GALTUNG, Johan. Peace Studies and Conflict Resolution: The Need for Transdisciplinarity. Transcultural Psychiatry, v. 47, n. 1, 2010, p. 20-32.

GRAHAM, Stephen. Cities under Siege: The New Military Urbanism. London: Verso, 2010. HUTCHISON, Emma; BLEIKER, Roland. Emotional Reconciliation Reconstituting Identity and Community after Trauma. European Journal of Social Theory, v.11, n.3, 2008, p.385-403.

JABRI, Vivienne. Peacebuilding, the local and the international: a colonial or a postcolonial rationality? Peacebuilding, v.1, n. 1, 2013, p. 3-16.

JCR. An Editorial. Journal of Conflict Resolution, v. 1, n. 1, 1957, p. 1-2.

JPR. An Editorial. Journal of Peace Research, v. 1, n. 1, 1964, p. 1-4.

KALDOR, Mary. New and Old Wars: organized violence in a global era. Cambridge: Polity Press, 1999.

KEEN, David. The economic functions of violence in civil wars. Oxford: Oxford University Press, 1998. 
LEDERACH, John P. Preparing for Peace. Conflict Transformation Across Cultures. Syracuse: Syracuse University Press, 1995.

LEDERACH, John P. Building Peace: Sustainable Reconciliation in Divided Societies. Washington, D.C.: United States Institute of Peace Press, 1997.

LEDERACH, John P. The Little Book of conflict transformation. Intercourse: Good Books, 2003.

LIOTTA, P.; MISKEL, J. The Real Population Bomb: Megacities, Global Security \& the Map of the Future. Dulles: Potomac Books, 2012.

MAC GINTY, Roger. Indigenous Peace-Making versus the Liberal Peace. Cooperation and Conflict, v. 43, n. 2, 2008, p. 139-163.

MOURA, Tatiana. Novíssimas Guerras: Espaços, Identidades e Espirais da Violência Armada. Coimbra: Almedina, 2010.

MUGAH, Robert. Deconstructing the fragile city: exploring insecurity, violence and resilience. Environment \& Urbanization, v.26, n.2, 2014, p.345-358.

ONU. A/3302 (1956) Report of the Secretary-General on the plan for an emergency international United Nations force. New York: United Nations, 1956.

ONU. A/47/277 (1992) An Agenda for Peace. New York: United Nations, 1992.

PORTER, Elisabeth. Peacebuilding: Women in international perspective. London: Routledge, 2007.

PUGH, Michael; COOPER, Neil. War economies in a regional context: challenges of transformation. London: Lynne Rienner, 2004.

PUGH, Michael. The Political Economy of Peacebuilding: A Critical Theory Perspective. International Journal of Peace Studies, v. 10, n. 2, 2005, p. 23-42.

PUREZA, José Manuel. O Desafio Crítico dos Estudos para a Paz. Relações Internacionais, v. 32, 2011, p. 5-22.

PUREZA, José Manuel; CRAVO, Teresa. Margem crítica e legitimação nos estudos para a paz. Revista Crítica de Ciências Sociais, v. 71, 2005, p. 5-19.

RASMUSSEN, Mikkel V. The West, Civil Society and the Construction of Peace. Basingstoke: Palgrave, 2003.

RAMSBOTHAM, Oliver; WOODHOUSE, Tom; MIALL, Hugh. Contemporary Conflict Resolution. Cambridge: Polity Press, 2008.

RENO, William. Warlord Politics and African States. Boulder: Lynne Rienner, 1999.

RICHMOND, Oliver P. The Transformation of Peace. Basingstoke: Palgrave, 2007a.

RICHMOND, Oliver P. Dadaism and the Peace Differend. Alternatives, v. 32, n. 4, 2007b, p. $445-472$.

RICHMOND, Oliver P. A Post-liberal Peace. Abingdon: Routledge, 2011a.

RICHMOND, Oliver P. Critical agency, resistance and a post-colonial civil society. Cooperation and Conflict, v. 46, n. 4, 2011b, p. 419-440. 
RICHMOND, Oliver P.; MITCHELL, Audra (org.). Hybrid Forms of Peace: From Everyday Agency to Post-Liberalism. Basingstoke: Palgrave, 2012.

RODGERS, Dennis. Slum wars of the 21st century: gangs, mano dura and the new urban geography of conflict in Central America. Development and Change, v.40, n.5, 2009, p. 949-976.

SHARP, Gene. The Politics of Nonviolent Action (Vol. I - Power and Struggle; Vol. II The Methods of Nonviolent Action; Vol. III - The Dynamics of Nonviolent Action). Boston: Porter Sargent Publishers, 1973.

SCHMID, Herman. Peace Research and Politics. Journal of Peace Research, v. 5, n. 3, 1968, p. 217-232.

STOHL, Michael; CHAMBERLAIN, Mary. Alternative futures for peace research. Journal of Conflict Resolution, v. 16, n. 4, 1972, p. 523-530.

TURNER, Mandy. Completing the Circle: Peacebuilding as Colonial Practice in the Occupied Palestinian Territory. International Peacekeeping, v. 19, n. 4, 2012, p. 492-507.

VÄYRYNEN, Raimo (ed.). New Directions on Conflict Theory: Conflict Resolution and Conflict Transformation. London: Sage, 1991.

VÄYRYNEN, Raimo. From Conflict Resolution to Conflict Transformation: A Critical Review. In JEONG, Ho-Won (Ed.) The New Agenda for Peace Research. Aldershot: Ashgate, 1999, Capítulo 7.

WAEVER, Ole. Peace and Security: Two concepts and their relationship. In GUZZINNI, Stefano e JUNG, Dietrich (Eds.) Contemporary Security Analysis and Copenhagen Peace Research. London: Routledge, 2004, Capítulo 5, p. 53-66.

WIBERG, Hakan. Investigação para a Paz: Passado, Presente e Futuro. Revista Crítica de Ciências Sociais, n. 71, 2005, p. 21-42. 


\title{
A Escola Galesa de Estudos Críticos em Segurança Internacional: 25 anos depois ${ }^{1}$ \\ The Welsh School of Critical Security Studies: 25 years after
}

DOI: $10.21530 /$ ci.v12n1.2017.609

Aureo de Toledo Gomes²

\section{Resumo}

Tendo como fio condutor os trabalhos de Ken Booth e Richard Wyn Jones, o artigo analisa a produção acadêmica da Escola Galesa de Estudos Críticos em Segurança Internacional. O argumento a ser desenvolvido é que, a despeito da produção de conceitos que contribuíram para o campo crítico em Segurança Internacional, o desenvolvimento teórico da escola ainda padece de insuficiências, sobretudo a controversa relação entre segurança e emancipação. Por conseguinte, derivar conceitos que informam a ação política torna-se tarefa difícil. Logo, a análise aponta para a necessidade de a Escola Galesa engajar-se em um debate teórico com perspectivas distintas, especialmente o pós-estruturalismo e o pós-colonialismo, o que pode produzir implicações importantes para a teoria e prática dos Estudos Críticos em Segurança Internacional.

Palavras-chave: Escola Galesa; Segurança Internacional; Emancipação.

\begin{abstract}
Anchored in the works of Ken Booth and Richard Wyn Jones, the article reviews the academic production of the Welsh School of Critical Security Studies. It is argued that despite a meaningful conceptual contribution to critical security studies, the Welsh School production is still pervaded by weaknesses, mainly the troubled security and emancipation equation. Thus, deriving concepts for political action becomes an arduous task. The analysis points

1 Gostaria de agradecer a Rafael Villa e Thiago Babo pelo convite para escrever sobre a Escola Galesa de Estudos Críticos em Segurança Internacional no âmbito de projeto desenvolvido junto ao NUPRI-USP. Ademais, agradeço novamente a Thiago Babo pelos comentários a uma versão prévia do trabalho durante o I Encontro Brasileiro de Estudos para Paz, em setembro de 2016. Não menos importante, o meu muito obrigado também se estende aos pareceristas anônimos da revista Carta Internacional.

2 Professor Adjunto III do Instituto de Economia e Relações Internacionais da Universidade Federal de Uberlândia. E-mail: aureotoledo@ufu.br

Artigo submetido em 10/01/2017 e aprovado em 05/04/2017.
\end{abstract}


towards the need for a thorough engagement with other theoretical lineages such as poststructuralism and post-colonialism. This dialogue might produce significant consequences for the theory and practice of critical security studies.

Keywords: Welsh School; Security Studies; Emancipation.

\section{Introdução}

Passado mais de um quarto de século desde a publicação do seminal ensaio Security and Emancipation, de Ken Booth (1991a), não restam dúvidas sobre o impacto do que se convencionou chamar Escola Galesa de Estudos Críticos em Segurança Internacional ${ }^{3}$. Conforme recente balanço, adeptos das ideias produzidas por tal corpo teórico contribuíram para a elaboração de análises sobre segurança não apenas a respeito do Ocidente, como também em relação a África, Ásia e outras regiões. Ademais, cursos de pós-graduação passaram a ser oferecidos em diversas universidades, assim como periódicos especializados ocupam cada vez mais espaço acadêmico (BILGIN, 2011). Em suma, a Escola Galesa estaria caminhando de forma sustentável ${ }^{4}$.

Todavia, tal diagnóstico otimista não é consensual, sobretudo quando o que se está sob escrutínio é o potencial heurístico desse corpo de ideias. Dentre as principais críticas, argumenta-se que a Escola Galesa carece de uma apreciação mais refinada sobre a ética da segurança e de como tais debates informam a natureza e dinâmica de um possível progresso social (BROWNING; MCDONALD, 2011). Ademais, há aqueles que argumentam em prol da retirada do termo Crítico, com base no fato de que o impulso emancipatório dos anos 1990 perdeu-se nos trabalhos mais recentes, substituído agora por horizontes progressistas mais modestos. O argumento é que, sim, devemos estudar segurança internacional, seus discursos e práticas, porém estudo não é sinônimo de crítica (HYNEK; CHANDLER, 2013).

Frente a tamanha controvérsia, o objetivo do trabalho é analisar o desenvolvimento da Escola Galesa de Estudos Críticos em Segurança Internacional.

3 Quando em caixa alta, Segurança Internacional refere-se ao subcampo de conhecimento das Relações Internacionais, enquanto segurança internacional refere-se ao objeto de estudo desse subcampo.

4 O primeiro curso em nível de pós-graduação sobre Critical Security Studies foi ministrado durante os anos de 1995 e 1996, conduzido por Booth, Wyn Jones e Nicholas Wheeler e com um público inicial de 5 alunas e alunos a partir do departamento de Política Internacional da Aberystwyth University, no País de Gales (Bilgin, 2011). Desde então, novos centros foram formados, particularmente no Reino Unido, Austrália e Turquia, aonde estão lotados egressos como Adam David Morton e Pinar Bilgin. Outrossim, a Escola Galesa passou a fazer parte do currículo escolar sobre segurança internacional em cursos de graduação e pós-graduação. 
Metodologicamente, o artigo realiza uma revisão da literatura, tendo como fio condutor obras de Ken Booth e Richard Wyn Jones, e a ela adiciona críticas contemporâneas ao trabalho da Escola, porém não se esquivando de, ao final, a partir de tal arrazoado, lançar suas próprias interrogações. A proposta se justifica, pois, para além da relevância da discussão, no Brasil, com exceção de Azevedo (2009), são raros os trabalhos que se propõem a aplicar ou mesmo realizar balanços sobre essa linhagem teórica.

O texto divide-se em quatro partes, excetuando-se esta introdução. A primeira seção apresenta os principais desenvolvimentos teóricos da escola, com ênfase na problematização ao conceito de segurança. Em seguida, ilustra-se a operacionalização dessa abordagem mediante trabalhos empíricos que fazem uso desse conjunto de ideias. A terceira seção discute críticas recentes à produção teórico-empírica da Escola Galesa. A última seção prospecta potenciais respostas às críticas levantadas.

\section{Teoria}

É praticamente lugar-comum destacar o impacto que o final da Guerra Fria teve sobre a área de Relações Internacionais ${ }^{5}$, e sobre o subcampo da Segurança Internacional em particular. Academicamente, os efeitos sistêmicos de tamanha transformação permitiram o fortalecimento de correntes críticas que, desde o começo dos anos de 1980, já questionavam a primazia neorrealista (GEORGE, 1994). Politicamente, o fim da bipolaridade reduziu a importância da competição estratégico-militar entre EUA e URSS para a compreensão da política internacional, abrindo espaço para que temas considerados marginais na agenda passassem a ocupar espaço (BUZAN; HANSEN, 2012).

A conjunção de ambos desenvolvimentos criou as condições para questionamentos sobre a natureza do conceito realista de segurança. Tomando Stephen Walt (1991) como referência dessa linhagem, os estudos de segurança teriam como propósito buscar conhecimento cumulativo sobre a ameaça, uso e controle da força militar. Todavia, quando confrontada com o cenário supracitado, tal definição parecia, ao menos para teóricos críticos, insuficiente por uma série de motivos, dos quais dois merecem maior apreciação.

5 Relações Internacionais em maiúsculas faz referência à área do conhecimento. Em caixa baixa, relações internacionais refere-se a seu objeto de estudo. 
O primeiro motivo seria uma insuficiência relativa ao objeto da segurança. Centrar a discussão no campo militar e estatal parecia restringir por demasiado a dimensão das ameaças contemporâneas. Tal viés estadocêntrico é, a um só tempo, um posicionamento normativo, pois trata o Estado como referente último e agente de segurança, para quem todos os cidadãos devem lealdade e onde o poder decisório está concentrado, assim como é uma opção metodológica, visto que envolve restringir as dinâmicas internacionais a partir de uma perspectiva cujo centro é o Estado. O segundo motivo seria as ancoragens ontológica e epistemológica dos estudos de segurança. O conhecimento cumulativo que Walt faz referência em sua definição é reflexo de uma concepção positivista de ciência, no qual o objetivo é a busca por leis causais que informariam o comportamento humano. As implicações de tal posicionamento estão longe de serem incontroversas. Ontologicamente, assume-se uma determinada concepção de subjetividade humana, entendida a partir da imagem de seres racionais que fazem uso instrumental da razão vis-à-vis uma realidade externa com a qual se relacionam de forma objetiva. Epistemologicamente, pressupõe-se uma separação entre sujeito cognoscente e objeto, assim como procura-se separar fatos de valores (KRAUSE; WILLIAMS, 1997).

Logo, uma série de analistas interrogou criticamente a natureza do conceito de segurança. Um importante ponto de confluência desses debates à época foi a conferência organizada pelo Center for International and Strategic Studies na York University, em Toronto, Canadá, entre 12 a 14 de maio de 1994. A partir dos debates suscitados, cunhou-se o termo critical security studies para abarcar os projetos intelectuais cuja meta era questionar o conceito de segurança. O principal produto desse evento foi a publicação, em 1997, do volume organizado por Keith Krause e Michael C. Williams, Critical Security Studies: Concepts and Cases.

Todavia, parece-nos razoável entender o prefixo crítico nesse momento em sentido lato. A conferência e o livro serviram como trampolim para fomentar estudos críticos em Segurança Internacional, porém não os preencheram com um conteúdo preciso (MUTIMER, 2007). Abriram-se então as portas para que contribuições marxistas, feministas, pós-estruturalistas, dentre outras, passassem a confrontar a tradição realista de segurança. A despeito de suas diferenças, todas essas abordagens compartilham reflexões sobre o conceito de segurança, sobretudo quem ou o que deve ser assegurado, assim como uma visão de segurança e de seus conceitos enquanto prática que não apenas descreve a realidade, mas também a constrói ao ser reiterada constantemente. 
Em sentido estrito, o termo Crítico - agora em caixa alta - foi imputado a um grupo específico de analistas, pois procuravam trazer para o subcampo da Segurança Internacional insights da Escola de Frankfurt, dos Estudos para Paz e de Antonio Gramsci, provavelmente incentivados pela contribuição seminal de Robert Cox (1981), o qual abriu a área de Relações Internacionais para o que se convencionou chamar de abordagens neogramscianas. Esse conjunto de autores e autoras ficou conhecido como Escola Galesa de Estudos Críticos em Segurança Internacional, capitaneada pelos trabalhos de Ken Booth e Richard Wyn Jones ${ }^{7}$.

Convém, contudo, recordarmos alguns pontos. Ao menos desde finais da década de 1970, Booth já vinha questionando os fundamentos dos estudos estratégicos ${ }^{8}$. Já em 1991, o mesmo autor havia publicado dois textos importantes - Security in Anarchy: Utopian Realism in Theory and Practice (BOOTH, 1991b) e o já citado Security and Emancipation - considerados marcos da Escola Galesa. Logo, percebe-se que não se tratam de trabalhos iniciados a partir da conferência de 1994, mas sim que a antecedem e que certamente foram potencializados pela conjuntura pós-Guerra Fria.

Que contribuições a Escola Galesa aportou às discussões sobre segurança internacional? Conforme dito, um de seus extratos conceituais é a tradição da Teoria Crítica frankfurtiana. Em linhas gerais, tal corrente tem a meta de compreender situações sociais de desigualdade, opressão e injustiça não apenas com o intuito de produzir análises, mas também identificar possibilidades concretas de superação dos problemas. O diagnóstico realizado deve apontar ao mesmo tempo tanto para as patologias quanto para os potenciais práticos de transformação. Como sintetiza Nobre (2004, p. 10), o ponto de vista crítico é aquele que vê o que existe a partir da perspectiva do novo que ainda não nasceu, mas que se insinua no presente.

6 Estudos para Paz (Peace Studies) fazem referência aos esforços de analistas que, a partir da década de 1960, passaram a incentivar discussões sobre paz. Destaca-se a produção de Johan Galtung (1969), particularmente sua distinção entre paz negativa, entendida enquanto ausência de conflito, e paz positiva, que deveria atentar também para aspectos estruturais que impediam a concretização de uma situação de paz.

7 Vale salientar que a Escola Galesa não é a única escola crítica em Segurança Internacional. Conforme Waever (2004), há ao menos duas outras importantes tradições. De um lado, temos a Escola de Copenhague liderada por Barry Buzan e Ole Waever e cuja principal contribuição para o campo é a teoria da securitização. Grosso modo, securitização seria uma prática performativa mediante a qual o ator securitizador identifica uma ameaça existencial a um objeto referencial, o que justificaria a adoção de medidas excepcionais. Ademais, temos ainda a contribuição da Escola de Paris, exemplificada pelos trabalhos de Didier Bigo e Jef Huysman, os quais, dentre outros pontos, destacam como os domínios doméstico e internacional de segurança se fundiram nos últimos anos e quais as implicações analíticas e políticas desse processo.

8 A referência aqui é o livro de Booth de 1979, Strategy and Ethnocentrism. 
O link entre essas ideias e o subcampo da Segurança Internacional jaz já no título do seminal artigo de Booth, de 1991, e posteriormente em seu livro de 2007, assim como em trabalhos de Wyn Jones (1995; 1999; 2005): segurança seria, teoricamente, emancipação. Destrinchando o argumento, partamos da definição padrão que Booth (1991a; 2005b; 2007) utiliza: segurança seria basicamente a ausência de ameaças. Quando mergulhamos nas nuances dessa afirmação, 3 pontos saltam aos olhos: a existência de um referente da segurança; um perigo, real ou provável; e o desejo de escapar das possibilidades ameaçadoras. Quando rumamos para o plano da prática é que os problemas surgem: que referentes devemos considerar? Que ameaças priorizar? Como o referente deve escapar das ameaças? Segurança seria um conceito relativamente simples, porém sua conceptualização e operacionalização são os pontos de controvérsia.

Booth (1991a) igualmente argumenta que as ameaças contemporâneas ao bemestar dos indivíduos e aos interesses dos países não derivam apenas de exércitos de vizinhos, mas sim de colapsos econômicos, opressão política, escassez de alimentos, rivalidades étnicas, dentre outras. Adicione-se o fato de que, muitas vezes, os principais perigos partem dos próprios Estados, entidades que, em tese, ao serem asseguradas, consequentemente proveriam segurança às suas populações. Segurança, portanto, não pode ser entendida como sobrevivência, pois sobrevivência significa meramente continuar a existir e não necessariamente viver bem. Logo, conforme Booth (2007), tal conceito deveria ser compreendido como sobrevivência-e-algo-a-mais (survival-plus), com este algo-a-mais referindo-se a alguma liberdade para se viver uma vida livre de ameaças existenciais e abrindo a possibilidade para escolhas.

Aqui, procede-se o enlace com emancipação. Para Booth (2007, p. 112), “emancipação procura garantir a segurança das pessoas daquelas opressões que as impedem de fazer aquilo que livremente escolheriam fazer, compatível com a liberdade dos outros" " . Não se trata de uma situação final, mas um horizonte, que talvez nunca alcancemos. Ademais, emancipação proporcionaria 3 características para a ação teórica e política. Primeiramente, a ancoragem filosófica para distinguir o verdadeiro do falso, isto é, para verificar quais assertivas devem ser levadas a sério. Segundo, como teoria do progresso - progresso entendido de forma reflexiva como um processo dinâmico e reversível e um resultado não necessariamente inevitável da ação política - emancipação oferece uma avaliação do mundo da

9 No original: "Emancipation seeks the securing of people from those oppressions that stop them carrying out what they would freely choose to do, compatible with the freedom of others". 
política internacional apontando que projetos de transformação são possíveis. Em terceiro lugar, como prática de resistência, emancipação seria um framework para realização de objetivos emancipatórios de curto, médio e longo prazos mediante ações políticas estratégicas alicerçadas com base na crítica imanente. Logo, segurança seria o meio; emancipação, o fim.

Com base nessa exposição, é possível depreender os passos analíticos dados pelo autor. Uma primeira ideia importante para a Escola Galesa seria compreender segurança como conceito derivativo. Em outras palavras, diferentes teorias produzem diferentes conceptualizações sobre o que seria segurança. Ainda que relativamente simples, as implicações dessa afirmação são significativas. Para além de ameaças aos indivíduos, estar seguro ou sentir-se seguro é entendido a partir de teorias políticas sobre nações, soberania, classe, gênero e outros fatos (BOOTH, 2005a). Consequentemente, o cânone realista sobre segurança internacional durante a Guerra Fria seria derivado de visões de mundo calcadas, por exemplo, em conceitos anglo-americanos, estatistas, militarizantes e masculinizantes.

Repensar segurança envolve dois passos analíticos adicionais. O primeiro é o que se convencionou chamar aprofundamento (deepening). Essencialmente, aprofundamento significa explorar as implicações da ideia que as atitudes e comportamentos vis-à-vis segurança são derivados de teorias sobre a natureza da política internacional, nos auxiliando a compreender as disputas subjacentes aos conceitos acadêmicos e às agendas políticas. O segundo movimento analítico é o alargamento (broadening), que envolve expandir a agenda dos estudos de segurança para além do escopo estatista e militar. Convém destacar que o alargamento não é necessariamente um movimento progressista, pois o mesmo pode acontecer a partir de uma lógica tradicional, estatista e militarizante. Alargamento, na perspectiva da Escola Galesa, deve ser pensado para além do viés estatal e derivado do aprofundamento, transformando temas de segurança em questões de teoria política, o que Booth (2005a) designa como politizar segurança (politicizing security).

Alcançamos então duas definições introduzidas por Ken Booth (2007). Para o autor, Estudos Críticos em Segurança Internacional devem ser entendidos como um subcampo acadêmico da disciplina de Relações Internacionais, cuja principal preocupação é a busca de conhecimento crítico sobre segurança. Conhecimento crítico implica entendimentos que escapem das estruturas, processos, ideologias e ortodoxias canônicas, ao mesmo tempo em que reconhece que as conceptualizações sobre segurança derivam de perspectivas políticas/teóricas/históricas. 
Adiante, Booth (2007) acrescenta a definição de Teoria Crítica da Segurança. Segundo o autor, tal teoria é tanto um compromisso teórico quanto uma orientação política comprometida com a construção da segurança mundial. Como comprometimento teórico, seria um arcabouço de ideias derivadas da tradição crítica em Relações Internacionais, especialmente da Escola de Frankfurt. Enquanto orientação política, é informada pelo objetivo de fortalecer a segurança mundial mediante políticas emancipatórias e redes de comunidade em todos os níveis, incluindo uma potencial comunidade abarcando outras comunidades políticas.

Com o intuito de descrever o trabalho do analista teoricamente informado pela Teoria Crítica da Segurança, Booth (2011) lança mão de uma analogia. Segundo o autor, analistas críticos deveriam não apenas "sussurrar na orelha do príncipe" as melhores opções políticas, mas procurar apartar-se o máximo possível da situação contemporânea e segurar um espelho, mostrando então para as pessoas como o mundo é e como continuará a ser caso nosso comportamento continue dominado pelas ideias que nos formaram. Nesse ponto, parece-nos apropriado introduzir a discussão de Wyn Jones $(1995$; 1999) sobre o papel do analista crítico.

Partindo da distinção gramsciana entre intelectual tradicional, aquele que seria capaz de transcender as clivagens sociais e produzir conhecimento universal (ambas situações que Gramsci julgava ser uma quimera), e intelectuais orgânicos, os quais teriam consciência de seu papel como articuladores e organizadores de interesses e aspirações de dada classe (GRAMSCI, 1971), Wyn Jones defende que esse último deveria ser o arquétipo do analista crítico. Dessa forma, a tarefa primordial dos Estudos Críticos em Segurança Internacional é, centrando-se nas experiências de homens, mulheres e comunidades para os quais a ordem mundial é causa de insegurança, e mediante uma crítica imanente, construir um discurso de segurança contra-hegemônico.

Há, em alguma medida, um caráter pedagógico nessa tarefa, dado que ao se criticar o bloco hegemônico, assim como apontando as diferentes concepções de segurança oriundas de diferentes entendimentos das potencialidades humanas, o analista crítico estaria, a um só tempo, contribuindo para a erosão do presente status quo e abrindo espaço para uma posição contra-hegemônica. Todavia, convém apontar que, na prática, a relação do analista com a classe ou movimento social com o qual está alinhado não é simplesmente de instruir e ensinar. Trata-se de um relacionamento reflexivo, em que a teoria alimenta a prática e que essa última também é capaz de reformular a teoria. Ao se proporcionar uma crítica da 
corrente ordem, o analista abre espaços políticos para que classes e movimentos sociais avancem em direção a objetivos emancipatórios.

\section{Prática}

Seguindo a tradição da Teoria Crítica, a Escola Galesa afirma a importância da práxis transformadora, em paralelo com as elaborações teóricas. Logo, tanto Booth (2005a) quanto Wyn Jones (1999) destacam a importância de estudos concretos que possam ampliar nossa compreensão sobre as várias realidades de insegurança existentes no mundo. Com esse aviso em mente, não nos parece menor a tarefa de proporcionarmos vislumbres de como algumas das ideais de todo esse cabedal teórico podem informar análises empíricas. Dessa forma, o objetivo da seção é duplo: ilustrar o potencial analítico da Escola Galesa para os casos selecionados e depreender desses estudos os arcabouços analíticos e metodológicos utilizados, auxiliando aqueles dispostos a utilizar tais ideias. Para tanto, foram selecionados dois exemplos, um mais alinhado a ideias gramscianas, outro de matriz frankfurtiana.

\section{O debate sobre Estados Falidos}

Após os atentados terroristas de 11 de setembro de 2001, houve uma proliferação de estudos acadêmicos sobre os chamados Estados Falidos. Tais trabalhos surgiram como uma tentativa de se entender a situação sociopolítica de países do dito Terceiro Mundo e como tal conjuntura incentivava a proliferação de grupos terroristas. Grosso modo, tal literatura compartilha alguns pressupostos, dos quais dois em particular se destacam.

Primeiramente, o fracasso estatal afloraria a partir da inabilidade das lideranças internas de determinados países em implantar instituições governamentais de natureza liberal, consideradas as mais adequadas para o desenvolvimento. Em segundo lugar, a ausência de tais instituições resultaria em problemas internos que extrapolariam as fronteiras nacionais e teriam potencial para atingir outros países. No caso específico do terrorismo, uma vez que tais países não seriam democráticos e o Estado teria dificuldades em prover bens públicos, a população não teria condições de vocalizar suas demandas, criando condições 
de insatisfação que serviriam de combustível para a proliferação de grupos terroristas (MONTEIRO, 2006).

Trata-se certamente de discussão controversa, a qual gerou significativa polarização acadêmica. À luz do diagnóstico acima sintetizado, autores como Helman e Ratner (1992) e Fukuyama (2005) defenderam a necessidade de se intervir em países considerados fracassados com o intuito de democratizá-los e expandir a ordem liberal pelo globo. Contudo, diversos analistas passaram a questionar o diagnóstico e suas implicações políticas, argumentando que a relação de causalidade entre fracasso estatal e terrorismo empiricamente não se sustenta, da mesma forma que o conceito criaria condições para práticas intervencionistas que estariam mais interessadas em manter o status quo internacional, ao controlarem as regiões entendidas como problemáticas (GOMES, 2011).

Uma interessante crítica a esse conceito é a desenvolvida por Pinar Bilgin e Adam David Morton (2007). De acordo com seus argumentos, há uma preocupação excessiva da literatura tradicional com os supostos sintomas do fracasso estatal, o que prejudicaria o entendimento das condições estruturais que levaram determinados países a tal situação. Nessa toada, Bilgin e Morton denominam tais análises tradicionais de externalistas e reducionistas. Externalistas por não incluírem o impacto que a globalização e o capitalismo contemporâneo tiveram sobre os países, esquivando-se de abordar como os Estados influenciam e são afetados por esses processos. De outro lado, são reducionistas, pois reduzem as ameaças à segurança ao terrorismo transnacional.

Conforme os autores (BILGIN; MORTON, 2002, 2004), a adjetivação de países enquanto falidos teria consequências problemáticas. A primeira é que sucesso e fracasso são analisados a partir de uma avaliação de capacidades coercitivas dos países para controlarem seus territórios, restringindo a discussão sobre a natureza da democracia em tais territórios. Outrossim, a visão da fragilidade estatal como comportamento desviante de normas internacionalmente reconhecidas serviria como justificativa para intervenções. Por fim, negligenciam-se os impactos dos programas de ajuda e estruturação econômica capitaneados por organizações como o Fundo Monetário Internacional e Banco Mundial, que muitas vezes criam e/ou exacerbam os sintomas do fracasso.

Teríamos, portanto, uma vilanização da pobreza, porquanto as análises concentram-se no comportamento político de tais países e nas implicações desse comportamento sobre a segurança da ordem econômica liberal, sem questionar o contexto econômico no qual tais comportamentos estão incluídos. Para além da 
crítica, Bilgin e Morton (2007, p. 21) apresentam uma alternativa analítica para uma discussão:

Uma maior consideração precisa ser dada a como as diferentes lógicas de soberania e capitalismo se combinam e formatam as condições estruturais que confrontam os Estados pós-coloniais - “falidos” ou qualquer outro adjetivo. Essas contradições são capturadas pela maneira como países específicos internalizam processos de acumulação de capital e formas de dominação (...) Em suma, uma historicização mais profunda dos processos de formação estatal no mundo não-ocidental é necessária, ciente das circunstâncias políticas e econômicas nas quais estes Estados evoluíram ${ }^{10}$.

Ainda que não esteja precisado um framework teórico-metodológico nas análises dos autores, é possível depreender conceitos da Escola Galesa nas entrelinhas do argumento, especialmente as cruciais ideias de aprofundamento e alargamento.

Num primeiro momento, ambos autores averiguam a relação entre a academia estadunidense e o mundo político durante e após a Guerra Fria, defendendo a tese de que a primeira foi anexada pelo segundo (BILGIN; MORTON, 2002). Uma das consequências dessa relação seria a representação de países pós-coloniais, sempre vistos a partir das ideias de deficiência e/ou fracasso vis-à-vis o Ocidente, cuja expressão Estado Falido seria o capítulo mais recente. Salvo melhor juízo, visualiza-se o aprofundamento quando os autores mergulham na avaliação das condições de produção do conhecimento sobre o tema e procuram explorar não apenas que ideias informam teoricamente a construção do conceito, mas ponderam sobre suas implicações concretas na prática política.

O alargamento ocorre quando os autores se movem além de uma lógica securitizadora, na qual Estados Falidos são vistos unicamente pelo prisma da segurança internacional, e do contraterrorismo em especial, e defendem que a análise da situação de tais países deveria levar em consideração questões sobre soberania, democracia e capitalismo ou, relembrando a famosa lição de Cox (1981), como a parte se encaixa no todo.

10 No original: "What needs to be given greater consideration is how the different logics of sovereignty and capitalism are intertwined which shape the structural conditions confronting postcolonial states-'failed'or otherwise. These contradictions are captured through the manner in which specific state forms internalize capital accumulation processes and associated forms of rule. (...) In sum, a thorough historicisation of state formation processes in the 'non-Western' world is required that is cognisant of the political economy circumstances within which such states have evolved". 


\section{Peacebuilding e emancipação}

No outono de 1992, preocupado com os conflitos em andamento na Croácia e Bósnia-Herzegovina, pois poderiam trazer consequências para a Macedônia, o presidente Kiro Gligorov solicitou à ONU a presença de tropas no país. Nesse sentido, em 11 de dezembro de 1992, o Conselho de Segurança decidiu adicionar um Comando Macedônico (Macedonian Command - MC) à United Nations Protection Force (UNPROFOR), que já atuava nos países supracitados. A UNPROFOR-MC objetivava monitorar as fronteiras da Macedônia com a Albânia e a então República Federativa da Iugoslávia e fortalecer a segurança e estabilidade do país mediante a presença da missão in loco.

Um ano após o envio das tropas, o diagnóstico dentro da ONU era de que a situação na Macedônia havia piorado, levando a uma expansão do mandato da UNPROFOR-MC. Já em 1995, toda a missão na ex-Iugoslávia foi reorganizada a pedido dos países receptores, culminando na criação da United Nations Preventive Deployment Force (UNPREDEP) para a Macedônia. Contudo, tendo em vista a deterioração da situação no Kosovo em 1998 e o veto chinês contra a extensão do mandato, a UNPREDEP encerrou suas atividades em 28 de fevereiro de 1999.

A presença da ONU na Macedônia é o foco de Eli Stamnes (2005). Sua preocupação é entender se o envio dos capacetes azuis foi um fator positivo para a melhoria da situação do país, centrada não em um viés estadocêntrico, mas sim na ideia de segurança humana, tal como delineada no Human Security Report, de 1994, desenvolvido pelo PNUD. A despeito de problemas organizacionais e logísticos, o resultado da análise apresenta a missão como um agente emancipatório no país, sobretudo pelo fato de que várias atividades desenvolvidas contribuíram para a melhora da vida da população.

Stamnes delineia claramente qual será sua estratégia analítica para a execução da pesquisa e sua grande inovação é a tentativa de operacionalizar a ideia de crítica imanente. Tomando a definição de Booth (2007) como referência, a crítica imanente procura identificar determinadas características em situações concretas (tais como dinâmicas positivas, agentes, entre outras) que possam ter possibilidades emancipatórias e, a partir de então, lutar para fortalecê-las. A autora construiu um enquadramento que procura traduzir analiticamente a meta da crítica imanente e, então, a aplica ao caso da UNPROFOR-MC e da UNPREDEP.

Basicamente, são dois movimentos que Stamnes realiza. O primeiro, denominado desconstrução, consiste na contraposição das concepções de segurança 
que informam o discurso da missão com as ideias de segurança que se expressam na prática. Aqui, o foco é apontar as contradições que potencialmente possam se tornar variáveis para transformações positivas. O segundo passo, reconstrução, é avaliar quais dessas variáveis podem ser de fato contribuições para um processo emancipatório. A avaliação é feita com base nas ideias de Axel Honneth, expoente da terceira geração da Escola de Frankfurt, o que demonstra uma possível segunda contribuição da autora: introduzir no âmbito da Segurança Internacional ideias desse autor.

Brevemente, a proposta de Honneth (2003) é entender as lutas sociais mediante a ideia de reconhecimento. Conforme o autor, indivíduos se formam e constituem suas identidades pessoais a partir do momento em que são reconhecidos intersubjetivamente. Existem três formas principais de reconhecimento que, se deterioradas, teriam potencial para motivar conflitos: amor, direito e solidariedade. Para o autor, mudanças sociais podem ser compreendidas mediante uma dinâmica de desrespeito. Logo, maus tratos e violação, que ameaçam a integridade física e psíquica, seriam uma violação ao primeiro tipo de reconhecimento. A privação de direitos e exclusão que ferem a integridade social do indivíduo como membro de uma comunidade política seriam exemplos de violação ao segundo tipo de reconhecimento. Por fim, um exemplo de violação da solidariedade seria degradação e ofensas, que afetam os sentimentos de honra e dignidade do indivíduo como membro de uma comunidade.

Em sua análise reconstrutiva, Stamnes contrapõe as ações empreendidas pela missão que mais se aproximaram da ideia de reconhecimento. Por isso, a ênfase no monitoramento de eleições, pois essas podem ser interpretadas como reconhecimento daqueles que fazem parte da comunidade política; na forma como organizações da sociedade civil foram reconhecidas como partícipes do processo de paz; e na maneira como a operação contribuiu para melhorar a situação socioeconômica da população, pois ajudou a mitigar formas estruturais de desrespeito à vida humana. A despeito das críticas ao pensamento de Honneth ${ }^{11}$, tem-se aqui uma tentativa de operacionalizar a ideia de crítica imanente, que pode auxiliar pesquisadores interessados em análises críticas sobre operações de paz.

11 Nancy Fraser critica a ideia de reconhecimento com base no fato de que, na forma como está posta a discussão, retira do debate questões de justiça distributiva. Em síntese, o reconhecimento deslocaria para um segundo plano a exploração socioeconômica. Para maiores detalhes, Fraser e Honneth (2003). 


\section{Críticas}

A despeito dos avanços, as contribuições da Escola Galesa não estão isentas de controvérsias. Dentre as principais interrogações, dois conjuntos saltam aos olhos: as que problematizam as insuficiências analíticas de seus conceitos, e aquelas interessadas em discutir as implicações teóricas e políticas do equacionamento entre segurança e emancipação.

Ao prospectarem o futuro dos estudos críticos, especialmente as produções da Escola de Copenhagen e da Escola Galesa, Browning e McDonald (2011) questionam a ausência de discussões em ambas linhagens sobre a política da segurança e a ética da segurança. Sobre o primeiro ponto, a ideia é verificar o interesse dos estudos críticos pelas formas como representações de segurança são capazes de definir identidade de grupos e, por conseguinte, habilitar determinadas políticas e legitimar certos atores como provedores de segurança. Em relação ao segundo ponto, trata-se de verificar como ambos conjuntos teóricos discutem o que seriam práticas consideradas progressistas vis-à-vis segurança, implicando tentativas de definir a natureza e a dinâmica do progresso. No arrazoado realizado, Browning e McDonald argumentam que Copenhagen e Aberystwyth não conseguem proporcionar um arcabouço convincente para a investigação de ambos os pontos.

Aqui é preciso distinguir que críticas cabem a cada escola. Se a política da segurança é um dos focos de maior atenção da Escola de Copenhagen, sobretudo pela centralidade da discussão envolvendo a ideia de securitização, para a Escola Galesa tal discussão não é o ponto principal. Booth (2007) concorda com o fato de que segurança tem grande poder e que enquadrar determinados temas por esse prisma eleva-os a um status de prioridade. Para além, Booth (2007, p. 168) é relativamente crítico à ideia de dessecuritização, pois essa "poderia ser vista como um movimento realizado por elites para retirar a significância das reais inseguranças"12. Trocando em miúdos, Booth considera que a dessecuritização pode desempoderar determinados temas e atores na medida em que tópicos urgentes passariam para um segundo plano do debate. Ademais, outra crítica de Booth direcionada à Escola de Copenhague é a distinção que fazem entre o âmbito da política e o âmbito da segurança, assim como a visão conservadora que possuem do último. A saída, segundo Booth, seria conceber segurança como teoria política.

12 No original: "Desecuritisation could indeed be a move by the powerful to lower the significance of real insecurities". 
Destrinchando a primeira crítica de Browning e McDonald, a contraposição entre as Escolas aponta um binário que perpassa esses estudos críticos. Se, para a Escola de Copenhagen, a securitização teria um efeito deletério, para Booth o efeito da segurança para fins de emancipação seria benigno. Logo, aparentemente independente de tempo e espaço, segurança teria sempre a mesma lógica. O que se perde é o reconhecimento de que segurança tem sim implicações distintas em tempos e espaços diferentes, indo além do que apenas consequências emergenciais ou benignas.

Com relação à ética da segurança, um dos pontos de controvérsia principal deriva da pouca problematização do que seriam práticas progressistas. Browning e McDonald destacam que Booth possui uma concepção fundacionista e materialista de emancipação e segurança, relacionando-a com condições materiais para sobrevivência. Contudo, em seu trabalho mais recente, Booth (2007) também passa a priorizar a dimensão procedural da emancipação, assim como a importância de questões relativas a deliberação. O que os autores apontam é que a relação entre deliberação e condições matérias vis-à-vis emancipação levanta questões complexas - por exemplo, como garantir espaços para deliberação em condições de desigualdades materiais -, mas que são pouco discutidas.

Em adição a esse ponto, ainda que enxergue emancipação de maneira progressiva, Booth, por vezes, restringe-se a repetir princípios éticos liberais, sobretudo em discussões envolvendo intervenções humanitárias. À guisa de exemplificação, o autor esquiva-se de discutir qual o papel da violência e o que seria emancipação em situações de genocídio, optando por apenas endossar a posição de que, se o envio de tropas é necessário, elas devem fazer mais bem do que mal ao contexto em foco. Nesse ponto, explicita-se ainda mais a base liberal da concepção de emancipação de Booth, interessada na defesa de direitos dos indivíduos, o que se choca com sua herança marxista, que pensa emancipação a partir de uma crítica imanente das condições estruturais e materiais e que tem em seu horizonte político o papel da revolução como meio para o progresso. Logo, um dos grandes problemas das insuficiências levantadas é que se torna difícil derivar posicionamentos éticos para ações específicas a partir de afirmações amplas e contraditórias.

Em linha semelhante, Peoples (2011) argumenta que Booth possui uma visão muito circunscrita do que seria emancipação. Isso se deve ao fato de que a Escola de Frankfurt é apenas uma das influências dentro do cabedal teórico do autor e que seu engajamento com ela não seria tão profundo - diferentemente de 
Wyn Jones (1999), cuja meta é traduzir tal tradição para os estudos de segurança. Contudo, discutir emancipação dentro da Escola de Frankfurt também é discutir o papel da violência e da resistência. Herbert Marcuse (apud PEOPLES, 2011), expoente dessa tradição, argumentou que, no limite, aderentes do princípio de não violência estariam perpetuando um sistema no qual a violência é inerente. Independentemente da controvérsia que afirmações como essas criam, autores alinhados à Frankfurt não se esquivaram de enfrentá-las. O mesmo não se poderia dizer sobre a Escola Galesa.

Não obstante a relevância das críticas até o momento arroladas, sem sombra de dúvida os maiores questionamentos são endereçados à relação estabelecida entre segurança e emancipação. Para explorarmos as avenidas de problematização possíveis a essa equação, parece-nos importante retomar novamente as definições de emancipação e crítica imanente.

Conforme descrito acima, "emancipação procura garantir a segurança das pessoas daquelas opressões que as impedem de fazer aquilo que livremente escolheriam fazer, compatível com a liberdade dos outros”13 (BOOTH, 2007, p. 112). Aqui cabem ao menos duas questões: quem é o agente emancipador? Quem é o sujeito a ser emancipado? Sobre crítica imanente, sua tarefa seria revelar determinadas características em situações concretas (tais como dinâmicas positivas, agentes, entre outras) que possam ter possibilidades emancipatórias. A questão que aqui salta aos olhos é revelar para quem. Outrossim, como realizar todas essas tarefas a partir de uma perspectiva de segurança?

Aradau (2004) interroga a proposta galesa a partir desse último questionamento. Quando Booth faz sua famosa proposição, emancipação torna-se problemática, pois engessa-se a possibilidade de transformação social, inserida agora dentro de uma lógica de segurança. Qual seria essa lógica? Em última instância, seria uma lógica ordenadora schmittiana, a qual ancora-se na discriminação entre amigo e inimigo e criação de hierarquias. Contudo, emancipação deveria ir além, informada, ao menos em tese, pela possibilidade de uma reconciliação social entre todos. Por que não, então, discutir emancipação a partir de enquadramentos distintos, eventualmente mais conectada com política democrática e questões de igualdade, justiça e/ou direitos humanos? Não menos importante, discutir emancipação dissociada de questões de produção é insuficiente, o que denota a pouca atenção da Escola Galesa com a dimensão econômica (HERRING, 2007).

13 No original: "Emancipation seeks the securing of people from those oppressions that stop them carrying out what they would freely choose to do, compatible with the freedom of others". 
Na mesma toada, inspirado por insights pós-estruturalistas que criticam a própria ideia de emancipação como uma grande meta narrativa capaz de servir como justificativa para práticas opressoras, Neocleous (2008) dispara a seguinte questão: será que no coração da lógica da segurança repousaria não liberdade e emancipação, mas, sim, um projeto cujo intuito é moldar as sociedades humanas a partir de determinada visão de mundo? Em caso de resposta positiva, Neocleous defende que o outro lado da moeda da segurança não seria emancipação, como Booth disse em 1991, mas, sim, opressão.

As demais questões acima apresentadas são tratadas de forma bastante aguda por Hynek e Chandler (2013). Numa conjuntura pós-Guerra Fria, preenchida por conflitos civis, pobreza e desigualdades, é inquestionável a existência de sujeitos a serem emancipados. Entretanto, quem seria o sujeito emancipador? Esse talvez seja o maior problema enfrentado pela Escola Galesa: uma teoria emancipatória sem um sujeito emancipador contra-hegemônico. A grande contradição embutida nesse conjunto de ideias é, portanto, o fato de que o projeto emancipatório seria conduzido por potências e instituições internacionais encarregadas de garantir (ou mesmo expandir) a ordem liberal. O diagnóstico dos autores é que o boom nos Estudos Críticos durante os últimos 25 anos explorou mais alternativas reformistas dentro da lógica dominante do que proporcionou claridade teórica às forças contra-hegemônicas. Aquém, portanto, de uma crítica imanente.

Quais foram as condições que provocaram tal estado de coisas? Aqui cremos ser interessante colocarmos à prova duas hipóteses. A primeira delas refere-se ao papel do analista e a quem ele revela as condições emancipatórias. Conforme nos diz Wyn Jones (1995), o arquétipo do analista crítico seria o intelectual orgânico gramsciano, que contribuiria para o processo de criação de consciência de si e para si de determinada classe. Todavia, como se comportar na relativa ausência de movimentos críticos? Frente a tal questão, Wyn Jones nos recorda dos movimentos pacifistas dos anos de 1980 que se beneficiaram do amontoado de ideias desenvolvidas nos anos 1960 e 1970 e aponta para o fato de que, nesses casos, o arquétipo de intelectual poderia ser de inspiração adorniana.

Após a publicação de Dialética do Esclarecimento, Adorno encontrava-se descrente sobre a capacidade do intelectual em influenciar a prática política. Dentro de uma conjuntura em que a razão instrumental havia dominado a sociedade capitalista, bloqueando as possibilidades de emancipação, Adorno via sua filosofia como "mensagens que deveriam ser lançadas no mar da 
história"14, com a esperança de que alguém no futuro as coletasse (apud WYN JONES, 1995, p. 307). Inspirado pelo exemplo dos movimentos pacifistas supracitados, Wyn Jones antecipava ser esse o caminho do analista crítico vis-à-vis a ausência de movimentos críticos.

Essa é a primeira hipótese que cremos ser interessante apresentar. Analistas críticos lançaram ideias e conceitos ao mar da história durante os últimos 25 anos, com a esperança de que, em algum momento, alguém as recolhesse e informasse sua prática política. Em parte, concordamos com Hynek e Chandler (2013), quando afirmam que ideias podem até terem sido criadas, mas clareza intelectual para forças contra-hegemônicas não foi desenvolvida. Nosso ponto de discordância localiza-se no motivo de tal tarefa não ser realizada. Aparentemente, Hynek e Chandler defendem o argumento de que esse resultado se deve à ênfase em advocacy ao invés de crítica por parte dos analistas críticos. Uma explicação complementar, e a segunda hipótese que apresentamos, é a de que houve um processo de gentrificação de parte das ideias desenvolvidas no bojo do movimento crítico.

O que seria esta gentrificação? Aqui, seguimos o insight de Cynthia Weber (2014). Gentrificação seria uma expressão cunhada para descrever o fluxo da população de classe média para outros bairros, removendo as pessoas mais carentes da região. Tal remoção não se restringe a prédios e moradias, mas também a ideias. Gentrificação implica, portanto, substituição, homogeneização e assimilação. A analogia proposta seria a seguinte.

Weber (2014) argumenta que os bairros mais carentes de Relações Internacionais, povoados pelos imigrantes intelectuais marxistas, pós-estruturalistas, feministas, teóricos críticos, pós-coloniais, dentre outros, estariam produzindo insights teóricos para uma disciplina que passava por uma crise intelectual no pós-Guerra Fria. Logo, o mainstream passou a ocupar partes dessa região, reconhecendo que ideias ali produzidas poderiam reavivar a disciplina. Contudo, os custos do contato foram grandes, com a incorporação de um vocabulário mais palatável para o grande público. Em suma, uma economia política internacional mais geral foi oferecida em substituição ao marxismo; a variável gênero substituiu o feminismo; construtivismo por pós-estruturalismo; entre outras consequências. Logo, não nos parece descabido afirmar que ideias produzidas no bojo do campo crítico em Segurança Internacional parecem ter sofrido processos de gentrificação. Duas delas prestam-se como exemplos.

14 No original: "Message in a bottle to be cast on the waters of history". 
A primeira é a própria ideia de Segurança Humana, que emerge a partir da discussão sobre novos referentes para além do Estado. Além das controvérsias envolvendo as diferentes concepções de Segurança Humana defendidas pelo PNUD e por potências médias como o Canadá, assim como as críticas que destacam sua ambiguidade (PARIS, 2001), o debate em torno do conceito reduziu-se a uma discussão em torno de um indivíduo genérico ou a humanidade como um todo, o que culmina em uma marginalização de questões importantes, como as de gênero, por exemplo (CHENOY, 2005; WALKER, 2006). A dimensão privilegiada do debate seria, então, aquela que se adequa mais a uma visão liberal sobre segurança, hoje hegemônica especialmente na literatura sobre peacebuilding. ${ }^{15}$

A segunda é a discussão envolvendo a ideia de ownership local em situações pós-conflito. A literatura crítica sobre peacebuilding argumenta que um dos motivos do fracasso do modelo liberal de construção da paz seria oriundo da natureza top-down do processo de intervenção e do pouco engajamento com a população e práticas locais. Consequentemente, houve um esforço em passar a condução dos processos de construção da paz para atores locais. Ainda que hoje seja comum encontrarmos em documentos da ONU a defesa do ownership local, para além da crítica de que esse seria um mero movimento retórico, muitas vezes sua operacionalização padece de problemas. A crítica mais frequente seria que o ownership local estaria embebido num framework liberal no qual o processo, de fato, seria reduzido à aplicação, pelos locais, de normas externas acordadas alhures e com pouca aderência ao país no qual serão implementadas (MAC GINTY, 2011).

Não restam dúvidas de que, em termos teóricos, a discussão crava interrogações importantes na produção da Escola Galesa e de outras linhagens críticas. Todavia, no âmbito da prática da segurança internacional, essa discussão tem ressonâncias igualmente problemáticas. Mais de um quarto de século de tentativas de experimentação conceitual e ações políticas podem até ter melhorado a vida de parte da população mundial, entretanto, conflitos civis ainda afetam a vida de muitos $^{16}$, sem mencionar suas externalidades, como a recente crise de refugiados europeia demonstra ${ }^{17}$. Assim, se as atuais alternativas emancipatórias vêm

\footnotetext{
15 A literatura sobre peacebuilding discute, dentre outros pontos, a estabilização de países saídos de conflitos. Há uma diversa gama de analistas que povoam tal discussão, desde liberais até marxistas, pós-estruturalistas e pós-colonialistas. Para uma introdução, ver Mac Ginty (2013).

16 À guisa de ilustração, apenas na Síria, em abril de 2016, a ONU estimava em 400.000 o número de mortos no conflito. (ALJAZEERA, 2016)

17 “Mais de 146 mil refugiados e migrantes chegaram à Europa em 2016”. (DIÁRIO DE NOTÍCIAS, 2016).
} 
fracassando e enfrentando resistências para serem implementadas ${ }^{18}$, parece-nos que uma pergunta pertinente a ser enfrentada poderia ser formulada nos seguintes termos: como atrair para os ditos processos emancipatórios os sujeitos a serem emancipados?

\section{Conclusões}

Tendo como pano de fundo a última interrogação lançada, cabe-nos ao fim explorar que eventuais respostas teóricas e políticas temos para a referida pergunta. Salvo melhor juízo, três merecem destaque.

A primeira é do próprio Ken Booth (2007). Ciente das complexidades teóricas embutidas no conceito, assim como da possibilidade de movimentos retóricos fazerem uso da emancipação meramente para justificar práticas políticas, o autor apresenta uma distinção entre o que seriam emancipações verdadeiras de emancipações falsas. Em linhas gerais, dentre as principais características de uma dita falsa emancipação, Booth (2007) destaca concepções que sejam estáticas e atemporais, que defendam políticas emancipatórias que produzam custos em terceiros ou utilizem emancipação como rótulo para acobertar o poder do Ocidente ou de qualquer outra entidade. Trata-se, então, de distinguir emancipações autênticas de falsas, mediante análise de circunstâncias históricas concretas.

Todavia, quem distingue e quem está sendo distinguido, ainda que sejam perguntas que só possam ser respondidas à luz da empiria, remetem a problemas relativos a quem emancipa, em relação a que se emancipa e quem seria o emancipado. Como visto nas críticas, tais questionamentos, por vezes, reduzem-se a julgamentos de valores, algo de difícil resolução, tanto no registro teórico, porém, especialmente, no âmbito político.

Uma segunda resposta vem a partir da experiência do que está convencionando-se chamar Escola de Manchester, anteriormente baseada em Saint Andrews, Escócia, e ancorada particularmente nos trabalhos de Oliver Richmond e Roger Mac Ginty. Sumariamente, ambos autores defendem o argumento de que a intervenção de atores externos com objetivos emancipatórios deve ser resultado da interação com atores locais, culminando em formas híbridas ou pós-liberais de paz e segurança (MAC GINTY, 2011; RICHMOND, 2011). Nessa perspectiva, a

18 Para o contexto de operações de paz, ver a coletânea organizada por Richmond e Franks (2009), na qual, mediante um conjunto de estudos de casos, os autores apontam as resistências que as missões da ONU enfrentam. 
resposta para a lacuna de legitimidade expressa pela pergunta que encerra a seção anterior jaz no reconhecimento da diversidade cultural e no aprofundamento das potencialidades da teoria pós-colonial. A principal consequência dessa abordagem seria diminuir os horizontes do que seriam práticas emancipatórias, sem possibilidade de universalização para outros contextos.

Por fim, uma terceira resposta depreende-se de discussões relativas ao alcance da emancipação. Aradau (2004) sugere um diálogo maior com as tradições pós-estruturalista e pós-marxista e a forma como um conjunto determinado de autores discute o dilema entre universalidade e diferença.

Em nosso entendimento, trata-se de alternativa relevante, porém que depende de um diálogo sem preconceitos e que supere afirmações simplistas como a de que “a rejeição pós-modernista de metanarrativas e de solidariedades universais não produz opções políticas para pessoas em perigo"19 (BOOTH, 2005c, p. 270). Para uma melhor compreensão de tais propostas, aqui há de se distinguir entre o plano ontológico e o plano ôntico. No plano ontológico, tradições pós-estruturalistas criticam as ditas metanarrativas com base no fato de que essas se prestam para construir posições de autoridade para decisões contingentes, tomadas em terreno indecidível, no qual outras opções poderiam ter sido autorizadas. Logo, não haveria nada essencialmente universal que transcendesse a história e que fosse tarefa teórica desvelar sua lógica e tarefa política concretizá-la (LACLAU, 2011). Pelo contrário: o máximo que podemos afirmar é que a história seria uma guerra de trincheiras, com projetos políticos distintos lutando para preenchê-la.

No plano ôntico, contudo, permitem-se diversas possibilidades políticas a partir de tais implicações ontológicas. Se não há lógica transcendental e tampouco um agente privilegiado de mudança histórica, o universal nada mais seria do que um particular que, em algum momento, se tornou dominante, o que, politicamente, abre espaço para a articulação de diversas lutas possíveis. Todavia, essas são constituídas a partir de antagonismos sociais: constroem-se mediante a contraposição com uma ordem que, ao mesmo tempo em que as impede de alcançarem suas demandas, são a condição para a própria articulação da luta política (LACLAU, 2011). Por exemplo, a um só tempo o patriarcalismo impediria a concretização dos ideais feministas, mas seria também condição de possibilidade para a formação de uma identidade política feminista. Logo, pluralizam-se as lutas políticas e multiplicam-se as possibilidades ditas emancipatórias. Ainda

19 No original: "The postmodern rejection of metanarratives and universal solidarities does not deliver a helpful politics to people in trouble”. 
que onticamente, por vezes, determinado projeto possa parecer a solução final, ontologicamente terá sempre um caráter contingente e precário, cuja sustentação depende do arranjo de forças de dado momento histórico, podendo posteriormente ser substituído por alternativa igualmente considerada emancipatória.

As duas últimas propostas discutidas permitem repensar o nexo entre segurança e emancipação, porém em registro distinto. Deve-se abandonar a ideia de uma sociedade finalmente reconciliada consigo mesma e isenta de conflitos. Essa sempre será heterogênea e preenchida por antagonismos sociais. Logo, a definição do que seria segurança igualmente depende de cortes antagônicos que, em última instância, vão definir quem são os agentes que proporcionam segurança, assim como aqueles que devem ser assegurados. Para além, onticamente, uma proposta de segurança pode eventualmente ser vista como a única possível, porém, ontologicamente, ela seria um projeto particular que em determinado momento histórico conseguiu hegemonizar dada conjuntura.

Da mesma forma, práticas emancipatórias seriam circunscritas localmente e marcadas por diversidades culturais. Dito de outra forma, definições sobre o que é o político, o econômico, segurança e emancipação devem ser compreendidas como historicamente inseridas em instituições, práticas cotidianas e sociedades, e não como entidades abstratas compreendidas de forma apriorística. Logo, recorrendo à Homi Bhabha (2010), se o hibridismo é possível não porque culturas possuem conteúdo similar, mas, sim, pelo fato de que são práticas interpelativas formadoras de símbolos e subjetividades, o que acaba abrindo novos espaços para articulação política, não nos parece descabido tentar compreender emancipação em termos semelhantes, como articuladora de propostas materiais, simbólicas e de subjetividades a partir de determinada conjuntura sócio-histórica.

Feitas as contas, lançamos a seguinte provocação: ao invés de segurança e emancipação, teríamos seguranças e emancipações.

\section{Referências}

ALJAZEERA. Syria death toll: UN envoy estimates 400,000 killed: Staffan de Mistura's estimate, which far exceeds those given by UN in the past, is not an official number. 13 ar. 2016. Disponível em: < http://www.aljazeera.com/news/2016/04/staffan-demistura-400000-killed-syria-civil-war-160423055735629.html > . Acesso em: 10 jul. 2016. ARADAU, Claudia. Security and the Democratic Scene: Desecuritization and Emancipation. Journal of International Relations and Development, 7, 2004, p. 388-413. 
AZEVEDO, Thalia. A Escola Galesa de Estudos Críticos em Segurança: Segurança como Emancipação. Dissertação de Mestrado. São Paulo: Programa de Pós-Graduação em Relações Internacionais Santiago Dantas (UNESP/UNICAMP/PUC-SP), 2009.

BHABHA, Homi. The third space (interview with Homi Bhabha). In: RUTHERFORD, Jonathan (ed.) Identity, Community, Culture, Difference. London: Lawrence \& Wishart, 1990, cap. 10, p. 207-221.

BILGIN, Pinar; MORTON, Adam. From 'Rogue' to 'Failed' State?: the Fallacy of Short-termism. Politics, vol. 24, n. 3, 2004, p. 169-180.

BILGIN, Pinar; MORTON, Adam. Historicising Representations of 'Failed States': beyond the Cold-War Annexation of the Social Sciences?. Third World Quarterly, vol. 32, n. 1, 2002, p. 55-80.

BILGIN, Pinar; MORTON, Adam. Rethinking State Failure: the Political Economy of Security. In: LAMBACH, Daniel; DEBIEL, Tobias (org.) State Failure Revisited I: Globalization of Security and Neighborhood Effects. INEF REPORT 87, 2007, Cap. 1, p. 7-31.

BILGIN, Pinar. The Continuing Appeal of Critical Security Studies. In: BRINCAT, Shannon; LIMA, Laura; NUNES, João (eds.). Critical Theory in International Relations and Security Studies: Interviews and Reflections. London: Routledge, 2011, Cap. 11, p. 159-171.

BOOTH, Ken. Beyond Critical Security Studies. In: BOOTH, Ken (ed.). Critical Security Studies and World Politics. Boulder: Lynne Rienner Publishers, 2005c, Cap. 11, p. 259-278.

BOOTH, Ken. Challenging the ideas that made us. In: BRINCAT, Shannon; LIMA, Laura; NUNES, João (eds.). Critical Theory in International Relations and Security Studies: Interviews and Reflections. London: Routledge, 2011, Cap. 3, p. 59-81.

BOоTH, Ken. Critical Explorations. In: BOOTH, Ken (ed.). Critical Security Studies and World Politics. Boulder: Lynne Rienner Publishers, 2005a, Introdução, p. 1-18.

BOOTH, Ken. Introduction to Part I. In: BOOTH, Ken (ed.) Critical Security Studies and World Politics. Boulder: Lynne Rienner Publishers, 2005b, p. 21-25.

BOOTH, Ken. Security and Emancipation. Review of International Studies, 17, 1991a, p. 313-326.

BOOTH, Ken. Security in Anarchy: Utopian Realism in Theory and Practice. International Affairs, vol. 67, n. 3, 1991b, p. 527-545.

BOOTH, Ken. Strategy and Ethnocentrism. London: Routledge, 1979.

BOOTH, Ken. Theory of World Security. Cambridge: Cambridge University Press, 2007. BROWNING, Christopher; MCDONALD, Matt. The Future of Critical Security Studies:

Ethics and the Politics of Security. European Journal of International Relations, vol. 19, n. 2, 2011, p. 235-255. 
BUZAN, Barry; HANSEN, Lene. A Evolução dos Estudos de Segurança Internacional. São Paulo: Editora UNESP, 2012.

CHENOY, Anuradha. A Plea for Engendering Human Security. International Studies, 42, 2005, p. 167-179.

COX, Robert. Social forces, states and world orders: beyond International Relations theory. Millennium, vol. 10, n. 2, 1981, p. 126-155.

DIÁRIO DE NOTÍCIAS. Mais de 146 mil refugiados e migrantes chegaram à Europa em 2016. 11 mar. 2016. Disponível em: < http://www.dn.pt/mundo/interior/maisde-146-mil-refugiados-e-migrantes-chegaram-a-europa-em-2016-5072412.html > . Acesso em: 10 jul. 2016.

FRASER, Nancy; HONNETH, Axel. Redistribution or Recognition? London: Verso, 2003. FUKUYAMA, Francis. Construção de Estados. Rio de Janeiro: Rocco, 2005.

GALTUNG, Johan. Violence, Peace, and Peace Research. Journal of Peace Research, vol. 6, n. 3, 1969, p. 167-191.

GEORGE, Jim. Discourses of Global Politics: a Critical Introduction to International Relations. Boulder: Lynne Rienner Publishers, 1994.

GOMES, Aureo. Questionando o Fracasso Estatal: um Balanço da Literatura Crítica. BIB, 1, 2011, p. 69-94.

GRAMSCI, Antonio. Selections from the Prison Notebooks. New York: International Publishers, 1971.

HELMAN, Gerald; RATNER, Steven. Saving Failed States. Foreign Policy, 89, 1992, p. 3-18. HERRING, Eric. Historical Materialism. In: COLLINS, Allan (ed.). Contemporary Security Studies. Oxford: Oxford University Press, 2007, Cap. 4, p. 42-53.

HONNETH, Axel. Luta por Reconhecimento: a Gramática Moral dos Conflitos Sociais. São Paulo: Editora 34, 2003.

HYNEK, Nik; CHANDLER, David. No Emancipatory Alternative, no Critical Security Studies. Critical Studies on Security, vol. 1, n.1, 2013, p. 46-63.

KRAUSE, Keith; WILLIAMS, Michael. From strategy to Security: Foundations of Critical Security Studies. In: KRAUSE, Keith; WILLIAMS, Michael (eds.). Critical Security Studies: Concepts and Cases. Minneapolis: University of Minnesota Press, 1997, Cap. 2, p. 33-58.

LACLAU, Ernesto. Emancipação e Diferença. Rio de Janeiro: EDUERJ, 2011.

MAC GINTY, Roger (ed.). Routledge Handbook of Peacebuilding. London: Routledge, 2013. MAC GINTY, Roger. International Peacebuilding and Local Resistance: Hybrid Forms of Peace. New York: Palgrave, 2011.

MONTEIRO, Leandro. O conceito de Estado Fracassado nas Relações Internacionais: origens, definições e implicações teóricas. Dissertação (Mestrado em Relações Internacionais). São Paulo: Programa San Tiago Dantas UNESP/UNICAMP/PUC-SP, 2006. 
MUTIMER, David. Critical Security Studies: a Schismatic History. In: COLLINS, Allan (ed.). Contemporary Security Studies. Oxford: Oxford University Press, 2007, Cap. 6, p. 67-86.

NEOCLEOUS, Mark. Critique of Security. Edinburgh: Edinburgh University Press, 2008.

NOBRE, Marcos. A Teoria Crítica. São Paulo: Jorge Zahar, 2004.

PARIS, Roland. Human Security: Paradigm Shift or Hot Air? International Security, vol. 26, n. 2, 2001, p. 87-102.

PEOPLES, Columba. Security after Emancipation? Critical Theory, Violence and Resistance. Review of International Studies, 37, 2011, p. 1113-1135.

RICHMOND, Oliver; FRANKS, Jason. Liberal Peace Transitions: between Statebuilding and Peacebuilding. Edinburgh: Edinburgh University Press, 2009.

RICHMOND, Oliver. A Post-Liberal Peace. New York: Routledge, 2011.

STAMNES, Eli. Critical Security Studies and the United Nations Preventive Deployment in Macedonia. In BELLAMY, Alex; WILliAMS, Paul (eds.) Peace Operations and Global Order. London: Routledge, 2005, Cap. 8, p. 161-181.

WAEVER, Ole. Aberystwyth, Paris, Copenhagen: new schools in security theory and their origins between core and periphery. In: $46^{\circ}$ International Studies Association Annual Conference, 2004, Montreal. Disponível em: http://citation.allacademic.com/ meta/p_mla_apa_research_citation/0/7/4/4/6/pages74461/p74461-1.php. Acesso em: 27 fev. 2017.

WALKER, Rob. The Double Outsides of the Modern International. Ephemera, vol. 6, n. 1, 2006, p. 56-69.

WALT, Stephen. The Renaissance of Security Studies. International Studies Quarterly, vol. 35, n. 2, 1991, p. 211-239.

WEBER, Cynthia. Why is there no Queer International Theory? European Journal of International Relations, vol. 21, n. 1, 2014, p. 27-51.

WYN JONES, Richard. 'Message in a bottle'? Theory and Praxis in Critical Security Studies. Contemporary Security Policy, vol. 16, n. 3, 1995, p. 299-319.

WYN JONES, Richard. On Emancipation: necessity, capacity and concrete utopias. In BOOTH, Ken (ed.). Critical Security Studies and World Politics. Boulder: Lynne Rienner Publishers, 2005, cap. 09, p. 215-235.

WYN JONES, Richard. Security, Strategy and Critical Theory. Boulder: Lynne Rienner, 1999. 


\title{
A parceria entre Minas Gerais e o Banco Mundial: uma análise do uso de condicionantes como instrumento de influência
}

\author{
The partnership between Minas Gerais and the \\ World Bank: an analysis of the use of conditionality \\ as an influence tool
}

DOI: $10.21530 /$ ci.v12n1.2017.507

Diogo de Paula Oliveira ${ }^{1}$ Pascoal Teófilo Carvalho Gonçalves²

\section{Resumo}

Este trabalho se propõe a verificar a capacidade do Banco Mundial em influenciar a estratégia de desenvolvimento do governo de Minas Gerais, entre 2006 e 2012, por meio da imposição de condicionantes nos empréstimos realizados pelo primeiro ao segundo. Para cumprir tal objetivo, é apresentada a trajetória histórica do banco, visando compreender suas estratégias de atuação e seus instrumentos de influência. Posteriormente, foram abordados conceitos centrais para a atuação do Banco Mundial, como as condicionantes, a ownership e a seletividade. Por fim, realizou-se uma análise comparada dos documentos de empréstimos e dos planos estratégicos do Estado. A conclusão da pesquisa aponta no sentido de o Banco não exercer influência determinante na estratégia de desenvolvimento de Minas Gerais mediante o uso de condicionantes. O resultado está em linha com a nova forma de atuação declarada pelo BIRD, que mediante a verificação do nível de ownership como critério para o recebimento de empréstimos, não mais utiliza as condicionantes como instrumento de coerção. É plausível que o Banco Mundial exerça uma influência prévia na definição da estratégia de desenvolvimento estadual, uma vez que o Estado pode definir uma estratégia de desenvolvimento compatível à do BIRD para acessar suas linhas de financiamento.

Palavras-chave: Estratégia de Desenvolvimento; Cooperação Internacional para o Desenvolvimento; Banco Mundial; Minas Gerais; Condicionantes.

1 Especialista em Políticas Públicas e Gestão Governamental pelo governo do estado de Minas Gerais E-mail: diogoo_28@hotmail.com

2 Professor/pesquisador do departamento de Relações Internacionais da UFPB. E-mail: pascoalgoncalves@outlook.com

Artigo submetido em 19/08/2016 e aprovado em 16/03/2017. 


\section{Abstract}

This paper aims to examine the capacity of the World Bank to influence the development strategies of the government of Minas Gerais between 2006 and 2012 through the imposition of conditionality attached to its loans. To reach this objective, the trajectory of the bank is presented to understand its operational strategies and influence instruments. Next, important concepts such as conditionality, ownership and selectivity are analyzed. Last, a comparative analysis of the documentation for the loans granted, and the States' strategic plans is made. The conclusion of this research shows that the World Bank does not seem to exert a strong influence on Minas Gerais' development strategy through the use of conditionality. This result is in line with what the IBRD declares to be its new loan policy. By analyzing the ownership level of a country as a criterion for receiving loans, the World Bank does not use conditionality as a coercive instrument. It is plausible that the Bank does exert its influence in a previous stage, when the government is deciding its development strategy, since it might be an interesting option for governments to choose strategies compatible with those defended by the Bank, as a way to access its funds.

Keywords: Development strategies; International Cooperation for Development; World Bank; Minas Gerais; Conditionality.

\section{Introdução}

O Banco Mundial foi criado em 1944 como Banco Internacional de Reconstrução e Desenvolvimento (BIRD), tendo em vista auxiliar na reconstrução da Europa no Pós-Guerra. Somente a partir dos anos de 1960, todavia, o banco passa a prestar auxílio para o desenvolvimento dos países do chamado Terceiro Mundo. Em um primeiro momento, o auxílio era direcionado a projetos de infraestrutura, mas, posteriormente, o combate à pobreza também passou a ser contemplado. A partir da década de 1980, o BIRD constata que o apoio a projetos isolados não seria suficiente para produzir desenvolvimento, caso a estrutura institucional do país financiado não fosse adequada. Com isso, o banco introduz os empréstimos de ajuste estrutural, voltados para o financiamento de políticas e não apenas de projetos (SANTOS JUNIOR, 2010). É a partir daí que as condicionantes - condições definidas em contrato que devem ser cumpridas para que o BIRD proceda à liberação de recursos - passam a ser utilizadas mais extensivamente.

Todavia, a partir dos anos de 1990 e a utilização de condicionantes atreladas ao Consenso de Washington, o Banco Mundial passa a adotar conceitos como ownership e seletividade em seus programas de empréstimo e ajuda. Nesse sentido, 
o interesse de um determinado país em perseguir certas reformas, independente de incentivos externos, passa a ser visto como essencial: seria mais eficiente emprestar apenas para tais países.

Tendo em vista esse contexto, temos que, desde sua fundação, o Banco Mundial realizou 16 empréstimos ao estado de Minas Gerais, sendo cinco no período entre 2006 e 2012. Desses cinco, quatro foram empréstimos para o financiamento de políticas públicas, chamados de Parcerias para o Desenvolvimento de Minas Gerais, que financiaram parte da reforma de Estado conhecida como Choque de Gestão.

O presente artigo parte da hipótese de que o Banco Mundial, por meio do atrelamento da liberação de recursos ao cumprimento de condicionantes definidas em contrato, consegue influenciar a estratégia de desenvolvimento e, por conseguinte, a elaboração e implementação de políticas públicas nos Estados para os quais realiza empréstimos ${ }^{3}$. De forma mais específica, se buscará entender em que medida as condicionantes impostas em três empréstimos realizados entre 2006 e 2012 influenciaram a política de desenvolvimento de Minas Gerais. Caso a hipótese apresentada seja confirmada, se depreenderá que o BIRD consegue impor condicionantes que são estabelecidas de forma externa aos governos democráticos e, possivelmente, forçam a implementação de políticas que não respondem aos anseios da população. Dessa forma, a parceria com o Banco Mundial poderia ser considerada como um fator de interferência na soberania do estado e de enfraquecimento do processo democrático.

Tendo em vista a corroboração ou refutação de nossa hipótese, nossos objetivos específicos são: definir o modelo de desenvolvimento do Banco Mundial; entender como o Banco Mundial define quais ações serão financiadas e quais condicionantes serão aplicadas em um empréstimo; e verificar se há uma convergência entre os objetivos governamentais e as ações e condicionantes dos empréstimos do banco.

Cabe ressaltar que não trataremos nesse trabalho da relação entre democracia, desenvolvimento e a atuação do Banco Mundial, e, tampouco, entraremos em detalhes quanto ao processo de formulação de políticas públicas. Nosso foco está na verificação da capacidade de influência do BIRD sobre a estratégia de desenvolvimento do Estado de Minas Gerais via condicionantes.

O artigo está estruturado da seguinte forma: na primeira seção, será apresentada a evolução histórica do Banco Mundial, abordando as diferentes fases de atuação

3 No âmbito deste trabalho, entenderemos por formulação de políticas públicas o processo que traduz os propósitos e plataformas eleitorais em programas e ações que produzem resultados ou mudanças no mundo real, conforme Gatti (2011). 
do BIRD a partir da década de 1980. Com isso, busca-se compreender a evolução do conceito de desenvolvimento defendido pelo banco, assim como as estratégias empregadas para alcançá-lo. Na segunda seção, se abordará alguns conceitos importantes que pautam a atuação do BIRD a partir de 2003. Na terceira seção, serão apresentados os empréstimos realizados pelo Banco Mundial ao estado de Minas Gerais a partir de 2006, abordando o contexto de assinatura do empréstimo, seus objetivos e, principalmente, o nível de aderência entre os objetivos do empréstimo e os objetivos previamente declarados pelo governo em seu plano estratégico de longo prazo, o Plano Mineiro de Desenvolvimento Integrado (PMDI). Valemo-nos de revisão bibliográfica sobre o Banco Mundial e de análise documental, referente a empréstimos firmados entre o banco e o Estado de Minas Gerais a partir de 2006, assim como os PMDIs publicados entre 2003 e 2012.

\section{O Banco Mundial}

O Banco Mundial é uma organização intergovernamental composta por aproximadamente 190 Estados-membros e com atuação em mais de 100 países. Foi criado como Banco Internacional de Reconstrução e Desenvolvimento (BIRD) para a Europa após a Segunda Guerra Mundial e passou a atuar no apoio ao desenvolvimento dos países periféricos somente no fim dos anos de 1950, no âmbito da Guerra Fria (WORLD BANK, 2014).

Atualmente, seu principal objetivo é reduzir a pobreza em países em desenvolvimento e subdesenvolvidos a partir do fomento do crescimento sustentável (WORLD BANK, 2014). Porém, durante sua história, tanto os objetivos como a forma de atuar do banco sofreram grandes mudanças.

Em suas três primeiras décadas de existência, a atuação do BIRD se centrou, de maneira geral, no financiamento de projetos de infraestrutura, desenvolvimento agrícola e industrial, educação, planejamento familiar e combate direto à pobreza. Em meados da década de 1970, porém, o quadro de estagflação nos países ricos e as crises de endividamento nos países pobres, em grande parte, consequência dos choques do petróleo, levou o banco a repensar sua estratégia de atuação (BRESSER-PEREIRA, 1995).

Percebeu-se, naquele momento, que os empréstimos anteriores, voltados para projetos de infraestrutura, pouco contribuíam para corrigir as distorções da estrutura produtiva dos países financiados, e que o sucesso de um projeto não era suficiente 
para gerar desenvolvimento se os obstáculos estruturais ao crescimento não fossem corrigidos (STIGLITZ, 1999). Ou seja, em um país com condições estruturais ruins, mesmo um projeto bem-sucedido poderia não gerar os impactos esperados. A partir de tal constatação, é criado, ainda em 1979, o empréstimo de ajuste estrutural. Esse instrumento se diferenciava dos empréstimos para investimentos pelo fato de financiar políticas públicas e não projetos de investimento específicos.

Nesse período, o Banco Mundial passa a se valer cada vez mais das condicionantes, instrumentos que vinculam o recebimento de recursos à realização de certas ações consideradas essenciais pelo agente financiador. Segundo BresserPereira (1995), a crise da dívida gerou uma oportunidade para o banco impor condicionantes aos países subdesenvolvidos e, assim, influenciar as políticas econômicas locais, garantindo que diretrizes consideradas corretas pelos países ricos fossem seguidas. Seguindo a tendência de aprofundamento, nas décadas seguintes, as condicionantes passam a tratar de temas mais amplos, como a governança, reformas judiciais e a corrupção. Segundo Dreher (2004), entre 1980 e 1982, os programas de ajuste do BIRD possuíam em média 34 condicionantes. Já entre 1987 e 1990, a média passou a 56.

Ao identificar no Estado os fundamentos da crise, o BIRD passou a pressionar os países menos desenvolvidos a adotarem diversas medidas, posteriormente denominadas Consenso de Washington, centradas em: políticas comerciais e de preço, com abertura dos mercados e da utilização de preços internacionais; políticas de poupança e investimento, com a promoção da desregulação do setor financeiro e do investimento privado; política orçamentária, que deveria trazer a diminuição dos gastos públicos improdutivos e do gasto unitário dos programas sociais; e reformas institucionais, por intermédio do aumento da eficiência ou privatização das empresas públicas e pelo aumento da participação do setor privado na produção dos bens públicos (LICHTENSZTEJN, 2010; RUGER, 2005).

John Williamson (2004) definiu o Consenso de Washington como uma lista de dez reformas estruturais específicas que as instituições sediadas em Washington (FMI, Banco Mundial etc.) consideravam como precondição para os países ainda pobres, em particular da América Latina, retomarem o crescimento. As dez áreas definidas pelo Consenso eram: disciplina fiscal; reorientação dos gastos públicos; reforma tributária; privatização; desregulamentação; liberalização comercial; liberalização financeira; investimento direto estrangeiro; regime cambial competitivo; e propriedade intelectual. Destarte, as práticas já eram comuns nos programas de reforma da década passada (CHIARI, 2000; BÉJAR, 2002). 
Nesse período, surgem os programas de ajustes estruturais de segunda geração, que agora, além das dez diretrizes originais, apresentavam maior foco na melhoria das instituições, devido ao reconhecimento de sua influência nos resultados das reformas de ajustes estruturais (RODRIK, 2006).

A segunda geração de ajustes também serviu ao propósito de reconciliar Estado e mercado. O enfoque do BIRD vai do Estado mínimo, defendido nos anos 1980, para o Estado eficiente. Reconheceu-se naquele momento que o Estado cumpria um importante papel na criação das condições econômicas, sociais e institucionais essenciais para o florescimento do mercado. Assim, o banco passa a defender a transição da administração pública do modelo burocrático para o gerencial, tornando o Estado um provedor de bens públicos e um regulador do desenvolvimento (SANTOS JUNIOR, 2010).

No início da década de 2000, principalmente a partir de 2003, era forte a percepção que o Consenso de Washington havia falhado. Eram raros os casos de sucesso resultantes da aplicação das medidas prescritas. Eventos como a incapacidade de os países africanos realizarem o take-off, apesar das reformas realizadas, e as sucessivas crises financeiras na América Latina, Leste Asiático, Rússia e Turquia fortaleceram a percepção de fracasso do Consenso (CYPHER, 1998; RODRIK, 2006).

Ademais, conforme sustenta Ravallion (2016, p. 87), o Consenso de Washington era considerado

previsível demais para ser crível como uma prescrição política. Ele listava um conjunto único de políticas, mas os governos dos países em desenvolvimento viam que havia múltiplos caminhos para o sucesso do desenvolvimento. Em particular, a rota alternativa ao Consenso de Washington tomada pela China desde os anos 1980 era um exemplo para todos verem ${ }^{4}$.

Apesar de a maioria dos países terem se comprometido com a implementação dos ditames do Consenso, a América Latina alcançou um crescimento do PIB per capita médio no período entre 1991 e 2000 de apenas 1,62\% ao ano, nível superior apenas ao da África Subsaariana, e muito abaixo dos 7,07\% ao ano alcançados no Leste Asiático. Além do desempenho do PIB, o fluxo de investimentos para a região não se deu da forma prevista e o saldo na balança comercial apresentou

4 No original: "too formulaic to be credible as a policy prescription. It listed a single set of policies, but governments of developing countries see for themselves that there were multiple paths to development success. In particular, the non-Washington Consensus route taken by China since 1980 stood an example for all to see”. 
sucessivos déficits, contribuindo para a deterioração da situação fiscal via balanço de pagamentos (ANCOCHEA, 2009; BÉJAR, 2002; CYPHER, 1998) $)^{5}$.

É nesse contexto que o Banco Mundial lança, em 2005, um documento denominado Economic Growth in the 1990s: Learning from a Decade of Reform (WORLD BANK, 2005a). Nele, o banco se distancia definitivamente do Consenso de Washington ao afirmar que não há fórmulas universais para o desenvolvimento. Pelo contrário, o documento aponta para a humildade, a diversidade de reformas, a seletividade e a experimentação. Ressaltou-se a importância de levar em conta o contexto em que serão aplicadas as reformas, já que, em contextos diferentes, problemas iguais podem ter soluções distintas. Posteriormente, Robert Zoellick, presidente do banco entre 2007 e 2012, reforça essa posição ao defender que o Banco Mundial deveria aceitar o pluralismo e as políticas de desenvolvimento pautadas pela prática e não apenas pela visão da academia (ENNS, 2015; RODRIK, 2006; STIGLITZ, 2008).

No campo prático, a primeira metade dos anos 2000 também trouxe uma importante mudança nos instrumentos de empréstimo do banco. Em 2004, o Banco Mundial cria o Empréstimo para Política de Desenvolvimento (do inglês, Development Policy Loan - DPL). Em um contraponto aos empréstimos de ajuste estrutural, governados pelo Consenso de Washington, os DPLs não mais prescrevem um conjunto único de reformas a ser seguido. Ao contrário, a partir da percepção de que as reformas só teriam sucesso se o país financiado considerasse que sua realização estava no seu melhor interesse, o banco passa a financiar os programas de reforma criados e apoiados internamente. Isto se deve, em grande parte, a estudos que demonstraram que a aplicação de condicionantes nos empréstimos tinha baixa efetividade. Com isso, as condicionantes se tornam mais restritas, abordando apenas os pontos considerados críticos para o sucesso do programa (PALONI; ZANARDI, 2005) ${ }^{6}$.

Outra mudança relevante que teve início nesse período e ganhou força no banco desde então, foi a renovação do foco no combate à pobreza. O atual presidente (2012 - presente) do Banco Mundial, Jim Yong Kim, apresenta a erradicação da pobreza até 2030 e o aumento da prosperidade entre os $40 \%$ mais pobres nos países em desenvolvimento e subdesenvolvidos como a dupla missão da instituição.

5 O período pós-Consenso na América Latina também é conhecido como “pós-liberal” ou "contencioso de Washington”. Para maior profundidade nesse assunto, ver Marangos (2008), Montiel (2007), Fine, Lapavitsas e Pincus (2001) e Katz (2015).

6 Segundo Ravallion (2016), atualmente cerca de um quarto dos empréstimos do BIRD envolvem os DPLs. 
Tal foco justifica em grande parte a continuidade dos empréstimos para países em um estágio de desenvolvimento um pouco mais avançado, como Brasil e México, por exemplo. Segundo Ravallion, nos últimos 15 anos, o aumento do gasto com proteção social nos países em desenvolvimento teve amplo apoio financeiro do Banco Mundial (CLEMENS e KREMER, 2016; RAVALLION, 2016).

\section{Condicionantes, Ownership e Seletividade}

A partir do reconhecimento da limitada eficiência da aplicação de condicionantes, o Banco Mundial passa a adotar conceitos como ownership e seletividade como partes centrais de seus programas de empréstimo e ajuda. Abordaremos tais conceitos e discutiremos como essas novas ideias influenciaram a atuação do Banco Mundial.

O termo condicionante diz respeito ao processo através do qual as instituições financeiras internacionais fazem empréstimos com base no compromisso do mutuário de promover certo conjunto de políticas públicas (SACHS, 1989). É dizer, uma condicionante vincula o recebimento de certos benefícios à realização de um conjunto de ações, sejam elas reformas institucionais ou a implementação de políticas públicas, de forma prévia ou posterior ao empréstimo.

Desde que começaram a ser utilizadas com maior frequência na década de 1980, as condicionantes se tornaram um tema polêmico, sendo analisadas e criticadas por serem intrusivas, corrosivas e ineficientes (KOEBERLE, 2003). Segundo Drazen (2006), o debate sobre condicionantes gerou questões tanto de cunho pragmático quanto conceitual. No campo pragmático, as principais questões apresentadas foram: “Quão efetivas são as condicionantes em ajudar os programas de assistência do FMI ou do Banco Mundial em alcançar seus objetivos? E como elas podem ser mais efetivas?7” (DRAZEN, 2006, p. 5). Por outro lado, no campo conceitual, o questionamento diz respeito a como deve ser a relação entre os organismos internacionais de financiamento e os países soberanos que recorrem aos empréstimos, sendo esta relação definida pela forma como as condicionantes são aplicadas.

As críticas quanto à efetividade das condicionantes, mais abundantes e complexas, tratam da capacidade (ou incapacidade) das instituições financeiras

7 No original: "How effective has conditionality been in helping IMF or World Bank assistance programs achieve their aims?, and How can it be made more effective?" 
internacionais de forçarem a realização de reformas que não ocorreriam em sua ausência. Segundo Santiso (2001), o fracasso das condicionantes em gerar reformas sustentáveis é de amplo conhecimento.

A principal fonte da ineficiência das condicionantes são os incentivos que o Banco Mundial tem para emprestar seus recursos. Segundo Dreher (2004), como o BIRD financia seus empréstimos com dinheiro proveniente do mercado de capitais, ele sofre uma forte pressão para emprestar os recursos que possui. Com isto, a liberação de recursos continua a tomar precedência sobre uma preocupação com o aumento da qualidade dos instrumentos de empréstimo e doações, das condicionantes que o acompanham e do impacto geral do programa na performance do mutuário (RANIS, 2006). Portanto, é fácil afirmar que não é interessante para o BIRD determinar critérios claros que poderiam resultar no cancelamento automático de um empréstimo. Dessa necessidade de emprestar seus recursos resulta, portanto, que o banco mundial quase nunca cancela o repasse de recursos, mesmo que as condições acordadas não sejam cumpridas (DREHER, 2004).

Devido à falta de vontade do banco de forçar o cumprimento das condicionantes de forma mais rígida, o próprio BIRD reconheceu que, quando não há o interesse do governo recipiente em realizar as medidas acordadas, as condicionantes costumam falhar (WORLD BANK, 2005b; KOEBERLE, 2003; RANIS, 2006). Esse interesse em realizar certo conjunto de reformas é denominado ownership. Segundo Koeberle (2003), quando falta ownership, as condicionantes são incapazes de levar à adoção de melhores políticas públicas. Diversos estudos empíricos demonstram que mudanças nas políticas públicas, em geral, são fruto da economia política do país e não de influências externas. Porém, se há compromisso e capacidade para realizar as reformas, os empréstimos condicionados podem "acelerar, ampliar e alargar as reformas, aumentando seu impacto e, possivelmente, contribuindo para o crescimento e desenvolvimento ${ }^{8}$ " (KOEBERLE, 2003. p. 258). Clemens e Kremer (2016) apontam o Bolsa Família e o Progresa, programas de transferência monetária condicionada do Brasil e do México, respectivamente, como exemplos desse efeito. Segundo o autor, apesar de se tratarem de inovações internas, a avaliação e a promoção desse tipo de política pelo Banco Mundial gerou legitimidade e credibilidade para os programas.

8 No original: "accelerate, broaden, and deepen it, enhancing its impact and hopefully contributing to growth and development”. 
Segundo o Banco Mundial, ownership pode ser definida como algo que "inclui forças políticas, econômicas e sociais, formais e informais, que determinam a prioridade que o governo, a sociedade civil e o setor privado dão a um objetivo de desenvolvimento9" (WORLD BANK, 2011, p. 7). Já Drazen (2006), em uma conceituação mais ampla, aponta que ownership pode "a grosso modo, ser definida como a medida em que um país está interessado em perseguir certas reformas independentemente de qualquer incentivo provido por credores multilaterais ${ }^{10}$ " (DRAZEN, 2006, p. 51).

Tal concepção gera algumas dúvidas quanto à compatibilidade da ownership com a utilização das condicionantes. É dizer, se um país está realmente interessado em promover certa política pública, por que haveria a necessidade de definir condicionantes para tal? Drazen (2006) acredita que a resposta está na heterogeneidade de interesses dentro do país que recebe o empréstimo. Ele defende que, muitas vezes, o governo interessado em promover certa reforma ou política pública pode sofrer oposições internas e, nesses casos, as condicionantes podem cumprir o papel de reforçar a posição do governo. Para ele, quando a ownership sobre as reformas é total, o uso de condicionantes é redundante e desnecessário. Quando ela é nula, as condicionantes não são capazes de influenciar a implementação das políticas ou reformas.

Com o reconhecimento que as condicionantes são efetivas apenas nos casos onde há alguma ownership sobre as medidas acordadas, mesmo que ela não seja unânime, passou-se a advogar por um aumento da seletividade na alocação dos empréstimos do Banco Mundial (KOEBERLE, 2003). Se a ownership sobre as políticas condicionadas é necessária para a efetividade de um programa, então o BIRD deveria emprestar somente para os países que demonstram genuíno interesse em implementá-las.

Koeberle (2003) defende que a seletividade apenas mudaria o foco da tensão entre os países e o BIRD, do momento da negociação das condicionantes para o momento da avaliação anterior ao início da negociação de um empréstimo. Posição parcialmente apoiada por Morrow (2005), que acredita que países sem acesso a outras fontes de financiamento, e com alta necessidade de captar recursos, sofreriam uma forte pressão para aceitar ou fingir aceitar as reformas propostas pelo

9 No original: "Stakeholder ownership comprises formal and informal political, economic and social forces that determine the priority that government, civil society and the private sector give to a development goal."

10 No original: "may be roughly defined as the extent to which a country is interested in pursuing reforms independently of any incentives provided by multilateral lenders". 
Banco Mundial, sob pena de não terem acesso a qualquer fonte de financiamento. Portanto, a seletividade criaria incentivos para que possíveis mutuários adotassem (ou fingissem adotar) um conjunto de estratégias e reformas condizentes com a cartilha do BIRD, visando ter acesso a suas linhas de financiamento.

Na próxima seção, passaremos, então, a analisar o relacionamento entre o Estado de Minas Gerais e o Banco Mundial à luz desses conceitos.

\section{O Banco Mundial e o Estado De Minas Gerais}

Nesta seção abordaremos os quatro empréstimos relacionados às Parcerias para o Desenvolvimento de Minas Gerais, firmadas a partir de 2006. Visto que apresentamos a hipótese que o banco exerce sua influência por meio das condicionantes, não seria relevante analisar os demais empréstimos contratados por Minas Gerais, já que eles financiaram projetos de investimentos específicos e, por isso, possuíam baixa capacidade de influenciar a estratégia de desenvolvimento governamental.

Em nossa análise, verificaremos a aderência dos objetivos de cada empréstimo e de suas respectivas condicionantes com os objetivos estratégicos do Estado de Minas Gerais. Para tanto, contrastaremos o Plano Mineiro de Desenvolvimento Integrado - PMDI ${ }^{11}$, com os documentos dos empréstimos, publicados pelo Banco Mundial. A escolha do PMDI se deu não só por ser o documento que apresenta a visão estratégica de longo prazo do governo, e que serve de base para a elaboração dos demais planos governamentais, mas também por apresentar um conteúdo profundo e abrangente.

\section{A Parceria para o Desenvolvimento de Minas Gerais}

Em abril de 2006, o governo de Minas Gerais e o Banco Mundial assinam o contrato de empréstimo intitulado Parceria para o Desenvolvimento de Minas Gerais. Mediante essa operação, o BIRD emprestou US\$ 170 milhões ao estado, com o objetivo de dar suporte e aprofundar as reformas iniciadas com o Choque de Gestão, buscando melhorar o balanço fiscal, a efetividade do setor público e o desenvolvimento do setor privado (WORLD BANK, 2006).

11 O PMDI apresenta a visão de longo prazo do governo, assim como os objetivos prioritários para que se alcance o futuro desejado. Dentro de cada objetivo estratégico, são apresentadas diversas metas que permitiriam a realização do objetivo (MINAS GERAIS, 2003). 
Para essa operação, o instrumento utilizado foi o recém-criado DPL. Em geral, esse instrumento é utilizado para dar suporte a um programa de reformas institucionais ou ao desenvolvimento de políticas econômicas e setoriais consideradas satisfatórias pelo Banco Mundial. A utilização do DPL para o financiamento da Parceria representou um marco na atuação do BIRD no Brasil - esse foi o primeiro Empréstimo para Política de Desenvolvimento feito para um ente subnacional no país (WORLD BANK, 2006).

Com relação à estrutura do empréstimo, a Parceria para o Desenvolvimento de Minas Gerais possuía dois desembolsos, cada qual com suas condicionantes específicas. Uma das mudanças instituídas pelo DPL foi substituir as condicionantes ex post em favor de condicionantes prévias à realização do empréstimo. O primeiro desembolso tinha um valor de US\$100 milhões e deveria ser pago assim que o empréstimo entrasse em efeito. A liberação destes recursos estava condicionada ao cumprimento dos ditames da Lei de Responsabilidade Fiscal e do acordo de refinanciamento da dívida pública celebrado com a Secretaria do Tesouro Nacional (STN). Pode-se dizer, entretanto, que tal condicionante tinha caráter meramente formal, já que elas haviam sido cumpridas anteriormente à sua estipulação. Já a segunda liberação somava US\$ 70 milhões e estava condicionada ao alcance de todos os indicadores apresentados no Quadro 1 (WORLD BANK, 2006).

O alinhamento entre as ações apoiadas pela Parceria para o Desenvolvimento de Minas Gerais, as condicionantes definidas em contrato e os objetivos estratégicos do governo estadual constantes no PMDI 2003-2020 estão sintetizados abaixo. O Quadro 1 apresenta as áreas apoiadas pelo empréstimo seguidas pelos indicadores que condicionaram a liberação dos recursos, assim como as estratégias correspondentes definidas pelo governo no PMDI. 


\section{Quadro 1. Comparativo entre a Parceria para o Desenvolvimento de Minas} Gerais (2006) e o Plano Mineiro de Desenvolvimento Integrado - 2003-2020

\begin{tabular}{|c|c|c|c|}
\hline \multicolumn{2}{|c|}{$\begin{array}{l}\text { Parceria para o Desenvolvimento } \\
\text { de Minas Gerais }\end{array}$} & \multicolumn{2}{|c|}{$\begin{array}{l}\text { Plano Mineiro de Desenvolvimento } \\
\text { Integrado (2003-2020) }\end{array}$} \\
\hline $\begin{array}{l}\text { Áreas apoiadas pelo } \\
\text { empréstimo }\end{array}$ & $\begin{array}{c}\text { Indicadores } \\
\text { (Condicionantes) }\end{array}$ & $\begin{array}{c}\text { Área de } \\
\text { Resultado }\end{array}$ & Estratégia \\
\hline $\begin{array}{l}\text { 1. Cumprimento do } \\
\text { acordo estabeleci- } \\
\text { do com o Governo } \\
\text { Federal através do } \\
\text { Programa de Ajuste } \\
\text { Fiscal - PAF - e da } \\
\text { Lei de Responsabili- } \\
\text { dade Fiscal }\end{array}$ & $\begin{array}{l}\text { Atingir um superávit primá- } \\
\text { rio de } \mathrm{R} \$ 1,596 \text { milhões em } \\
2005 \text { e reduzir o gasto com } \\
\text { pessoal para } 60 \% \text { ou menos }\end{array}$ & Choque de Gestão & $\begin{array}{l}\text { Implementar estratégias e } \\
\text { tecnologias de gerencia- } \\
\text { mento das receitas e das } \\
\text { despesas, objetivando o } \\
\text { equilíbrio fiscal }\end{array}$ \\
\hline $\begin{array}{l}\text { 2. Redução do Custo da } \\
\text { dívida pública }\end{array}$ & $\begin{array}{l}\text { Pré-pagamento de pelo me- } \\
\text { nos R } \$ 100 \text { milhões de reais } \\
\text { de débitos flutuantes ou } \\
\text { consolidados não cober- } \\
\text { tos pelo acordo de refinan- } \\
\text { ciamento da dívida com } \\
\text { o Tesouro Nacional e não } \\
\text { devidos ao BIRD }\end{array}$ & & \\
\hline $\begin{array}{l}\text { 3. Modernização da } \\
\text { Subsecretaria da Re- } \\
\text { ceita }\end{array}$ & $\begin{array}{l}\text { Instalar pelo menos sete } \\
\text { novos módulos de informa- } \\
\text { ções computadorizadas de } \\
\text { gestão de tributos (SIARE) }\end{array}$ & Choque de Gestão & $\begin{array}{l}\text { Modernizar e reestruturar } \\
\text { a Receita Estadual, para } \\
\text { o incremento da receita } \\
\text { fiscal do Estado }\end{array}$ \\
\hline $\begin{array}{l}\text { 4. Otimização da gestão } \\
\text { de recursos humanos }\end{array}$ & $\begin{array}{l}\text { Instalar o novo sistema in- } \\
\text { tegrado de pagamento de } \\
\text { pessoal (SISAP) }\end{array}$ & Choque de Gestão & $\begin{array}{l}\text { Revisar o modelo de ges- } \\
\text { tão de pessoas, mediante } \\
\text { a adoção de política de } \\
\text { carreiras, desenvolvimen- } \\
\text { to e de remuneração dos } \\
\text { servidores, vinculadas a } \\
\text { resultados - qualidade e } \\
\text { produtividade }\end{array}$ \\
\hline $\begin{array}{l}\text { 5. Implementação do } \\
\text { Estado para Resulta- } \\
\text { dos (Administração } \\
\text { por resultados) }\end{array}$ & $\begin{array}{l}\text { Assinar pelo menos um } \\
\text { acordo de resultados adi- } \\
\text { cional e revisar pelo menos } \\
\text { cinco acordos de resultados } \\
\text { com agências estatais }\end{array}$ & & $\begin{array}{l}\text { Disseminação da prática } \\
\text { de implementação e ge- } \\
\text { renciamento de projetos e } \\
\text { de programas focados em } \\
\text { resultados }\end{array}$ \\
\hline
\end{tabular}


(continuação)

\begin{tabular}{|c|c|c|c|}
\hline \multicolumn{2}{|c|}{$\begin{array}{l}\text { Parceria para o Desenvolvimento } \\
\text { de Minas Gerais }\end{array}$} & \multicolumn{2}{|c|}{$\begin{array}{l}\text { Plano Mineiro de Desenvolvimento } \\
\text { Integrado (2003-2020) }\end{array}$} \\
\hline $\begin{array}{l}\text { Áreas apoiadas pelo } \\
\text { empréstimo }\end{array}$ & $\begin{array}{c}\text { Indicadores } \\
\text { (Condicionantes) }\end{array}$ & $\begin{array}{c}\text { Área de } \\
\text { Resultado }\end{array}$ & Estratégia \\
\hline $\begin{array}{l}\text { 6. Eficiência e econo- } \\
\text { mia na gestão logís- } \\
\text { tica e de suprimentos }\end{array}$ & $\begin{array}{l}\text { Instalação do módulo SIAD } \\
\text { para método de preço de } \\
\text { compras públicas (pregão } \\
\text { eletrônico) }\end{array}$ & Choque de Gestão & $\begin{array}{l}\text { Implementar programas } \\
\text { de melhoria contínua de } \\
\text { processos, para introduzir } \\
\text { o conceito de qualidade } \\
\text { na administração pública, } \\
\text { com ênfase nos sistemas } \\
\text { informatizados corpora- } \\
\text { tivos }\end{array}$ \\
\hline $\begin{array}{l}\text { 7. Transparência e aces- } \\
\text { so a informações go- } \\
\text { vernamentais }\end{array}$ & $\begin{array}{l}\text { Lançamento do website de } \\
\text { planejamento e gestão com } \\
\text { um módulo para monito- } \\
\text { ramento da execução dos } \\
\text { programas estruturais }\end{array}$ & Choque de Gestão & $\begin{array}{l}\text { Implementar política de } \\
\text { tecnologia da informação } \\
\text { e de governo eletrônico, } \\
\text { com uso intensivo da in- } \\
\text { ternet para prestar ser- } \\
\text { viços e divulgar metas e } \\
\text { resultados. }\end{array}$ \\
\hline $\begin{array}{l}\text { 8. Melhoria do ambien- } \\
\text { te de investimentos }\end{array}$ & $\begin{array}{l}\text { Integrar a cobrança do } \\
\text { ICMS ao sistema SIARE } \\
\text { junto ao registro do Siste- } \\
\text { ma Integrado de Adminis- } \\
\text { tração de Materiais e Servi- } \\
\text { ços (SIAD) }\end{array}$ & Choque de Gestão & $\begin{array}{l}\text { Descomplicar Minas Ge- } \\
\text { rais, facilitando a vida do } \\
\text { empreendedor. }\end{array}$ \\
\hline $\begin{array}{l}\text { 9. Parcerias público- } \\
\text {-privadas (PPP) }\end{array}$ & $\begin{array}{l}\text { Desenhar um mecanismo } \\
\text { de garantias estatais para } \\
\text { as PPPs }\end{array}$ & $\begin{array}{l}\text { Viabilização de } \\
\text { novas formas de } \\
\text { financiamento dos } \\
\text { empreendimentos } \\
\text { públicos }\end{array}$ & $\begin{array}{l}\text { Estabelecer marco legal } \\
\text { estadual que possibilite } \\
\text { a contratação de servi- } \\
\text { ços públicos no conceito } \\
\text { PPP - Parceria Público- } \\
\text {-Privada. }\end{array}$ \\
\hline
\end{tabular}

Fonte: Minas Gerais, 2003; World Bank, 2006 - elaboração própria.

A análise do quadro demonstra que as condicionantes do empréstimo mantiveram uma alta aderência ao PMDI, o que sugere que elas não serviram ao propósito de forçar o Estado a realizar reformas que não possuíam ownership, já que as medidas condicionadas faziam parte do plano estratégico previamente apresentado pelo governo de Minas Gerais.

\section{A Segunda Parceira para o Desenvolvimento de Minas Gerais}

A Segunda Parceria para o Desenvolvimento de Minas Gerais representou um aprofundamento na relação entre o Estado e o Banco Mundial, tanto em 
termos financeiros como em apoio técnico e troca de conhecimentos. O primeiro empréstimo dessa parceria, assinado em agosto de 2008, tinha o valor de US\$ 976 milhões. Segundo o Project Appraisal Document - relatório no qual o BIRD descreve o contexto, os objetivos, as ações e tudo aquilo considerado relevante ao empréstimo -, o governo de Minas Gerais solicitou a ajuda do Banco na implementação e aprofundamento da Gestão por Resultados nas principais secretarias setoriais. Para tanto, o BIRD daria apoio a três objetivos amplos do governo: melhorar a qualidade fiscal; desenvolver a qualidade e a inovação no setor público; e aperfeiçoar o controle e o monitoramento de resultados (WORLD BANK, 2008b).

Os três objetivos mencionados acima seriam aplicados em seis áreas de resultados definidas no Estado para Resultados, nome dado à segunda fase das reformas de Minas Gerais, com foco na melhoria dos serviços públicos e no crescimento econômico. Para cada área, governo e banco acordaram alguns indicadores que condicionariam o reembolso das despesas elegíveis. No total, foram escolhidos 24 indicadores que já constavam no Acordo de Resultados governamental, o que garantiu seu alinhamento com a estratégia do Estado e a capacidade desse de monitorá-los (WORLD BANK, 2008b).

No ano de 2010, oito novos indicadores nas áreas de qualidade ambiental e social, e alívio da pobreza foram incluídos na parceria e algumas das metas iniciais atualizadas. Essa alteração se dá devido à contratação de um financiamento adicional à Segunda Parceria para o Desenvolvimento de Minas Gerais. O novo empréstimo, realizado devido à perda de arrecadação resultante da crise mundial de 2008, teve um valor total de US\$ 461 milhões. Vale ressaltar que o novo empréstimo visou somente garantir que as reformas que estavam sendo empreendidas não fossem prejudicadas pela diminuição dos recursos disponíveis (WORLD BANK, 2010).

Assim como no caso da primeira Parceria para o Desenvolvimento de Minas Gerais, uma análise do PMDI 2007-2023 deixa claro que os projetos estratégicos financiados e as condicionantes mantiveram um alinhamento com os objetivos prioritários de longo prazo do governo. O Quadro 2, que contém os 32 indicadores como definidos no financiamento adicional à Segunda Parceria, demonstra tal situação. 


\section{Quadro 2. Comparativo entre a Segunda Parceria para o Desenvolvimento de} Minas Gerais (2008) e o Plano Mineiro de Desenvolvimento Integrado - 2007-2023

\begin{tabular}{|c|c|c|c|c|}
\hline \multicolumn{3}{|c|}{$\begin{array}{c}\text { Segunda Parceria para o Desenvolvimento } \\
\text { de Minas Gerais (2008) }\end{array}$} & \multicolumn{2}{|c|}{$\begin{array}{l}\text { Plano Mineiro de Desenvolvimento Integrado } \\
\qquad(2007-2023)\end{array}$} \\
\hline $\begin{array}{l}\text { Áreas apoiadas } \\
\text { pelo empréstimo }\end{array}$ & $\begin{array}{l}\text { Projetos } \\
\text { estratégicos }\end{array}$ & $\begin{array}{l}\text { Indicadores ligados } \\
\text { aos desembolsos } \\
\text { (Condicionantes) }\end{array}$ & $\begin{array}{l}\text { Área de } \\
\text { Resultado }\end{array}$ & Estratégia \\
\hline \multirow{9}{*}{ SETOR PÚBLICO } & $\begin{array}{l}\text { Choque de Gestão } \\
\text { Setorial }\end{array}$ & $\begin{array}{l}\text { Implementação dos } \\
\text { Acordos de Resultados } \\
\text { de } 1^{\text {a }} \text { etapa }\end{array}$ & \multirow{3}{*}{$\begin{array}{l}\text { Qualidade e Ino- } \\
\text { vação em Gestão } \\
\text { Pública }\end{array}$} & $\begin{array}{l}\text { Consolidar o Choque de Gestão } \\
\text { em todos os setores do Governo } \\
\text { Estadual e adensar seus benefícios } \\
\text { em transformações efetivas para a } \\
\text { sociedade mineira, com ênfase na } \\
\text { geração de resultados mensuráveis } \\
\text { nas Áreas de Resultados definidas }\end{array}$ \\
\hline & $\begin{array}{l}\text { Choque de Gestão } \\
\text { Setorial }\end{array}$ & $\begin{array}{l}\text { Implementação dos } \\
\text { Acordos de Resultados } \\
\text { de } 2^{\text {a }} \text { Etapa }\end{array}$ & & $\begin{array}{l}\text { Consolidar o Choque de Gestão } \\
\text { em todos os setores do Governo } \\
\text { Estadual e adensar seus benefícios } \\
\text { em transformações efetivas para a } \\
\text { sociedade mineira, com ênfase na } \\
\text { geração de resultados mensuráveis } \\
\text { nas Áreas de Resultados definidas }\end{array}$ \\
\hline & $\begin{array}{l}\text { Profissionalização } \\
\text { dos Gestores Pú- } \\
\text { blicos }\end{array}$ & $\begin{array}{l}\text { Certificação de funções } \\
\text { no Setor Público }\end{array}$ & & $\begin{array}{l}\text { Melhorar a qualidade dos serviços } \\
\text { prestados pelas instituições públi- } \\
\text { cas mineiras, por meio da } \\
\text { seleção, formação e desenvolvi- } \\
\text { mento de gestores públicos pro- } \\
\text { fissionais }\end{array}$ \\
\hline & $\begin{array}{l}\text { Modernização da } \\
\text { Gestão Fiscal }\end{array}$ & $\begin{array}{l}\text { Indicadores do Progra- } \\
\text { ma de Ajuste Fiscal do } \\
\text { Estado de Minas Gerais } \\
\text { (PAF) firmado com a } \\
\text { STN (Superávit primá- } \\
\text { rio e razão entre des- } \\
\text { pesa de pessoal e RCL) }\end{array}$ & \multirow{4}{*}{ Qualidade Fiscal } & $\begin{array}{l}\text { Manter o compromisso com o } \\
\text { equilíbrio fiscal, aprimorando a } \\
\text { prevenção e a mitigação de riscos } \\
\text { de gestão }\end{array}$ \\
\hline & - & $\begin{array}{l}\text { Balanço Operacional } \\
\text { bruto }\end{array}$ & & $\begin{array}{l}\text { Estabilizar e iniciar a redução da } \\
\text { despesa orçamentária como pro- } \\
\text { porção do PIB estadual, passo que } \\
\text { antecede uma política sustentável } \\
\text { de redução da carga tributária }\end{array}$ \\
\hline & - & $\begin{array}{l}\text { Participação dos Proje- } \\
\text { tos Estruturadores na } \\
\text { despesa orçamentária }\end{array}$ & & $\begin{array}{l}\text { Aumentar a aderência do orçamen- } \\
\text { to à estratégia de médio prazo, am- } \\
\text { pliando a participação dos Projetos } \\
\text { Estruturadores na despesa total }\end{array}$ \\
\hline & $\begin{array}{l}\text { Qualidade e pro- } \\
\text { dutividade do gas- } \\
\text { to setorial }\end{array}$ & $\begin{array}{l}\text { Gestão do sistema de } \\
\text { compras }\end{array}$ & & $\begin{array}{l}\text { Ampliar a qualidade e a produtivi- } \\
\text { dade dos gastos setoriais }\end{array}$ \\
\hline & - & $\begin{array}{l}\text { Aprimoramento da ges- } \\
\text { tão por resultados }\end{array}$ & - & - \\
\hline & - & $\begin{array}{l}\text { Fortalecimento da for- } \\
\text { mulação de políticas } \\
\text { públicas }\end{array}$ & - & - \\
\hline
\end{tabular}


(continuação)

\begin{tabular}{|c|c|c|c|c|}
\hline \multicolumn{3}{|c|}{$\begin{array}{c}\text { Segunda Parceria para o Desenvolvimento } \\
\text { de Minas Gerais (2008) }\end{array}$} & \multicolumn{2}{|c|}{$\begin{array}{l}\text { Plano Mineiro de Desenvolvimento Integrado } \\
\qquad(2007-2023)\end{array}$} \\
\hline $\begin{array}{l}\text { Áreas apoiadas } \\
\text { pelo empréstimo }\end{array}$ & $\begin{array}{l}\text { Projetos } \\
\text { estratégicos }\end{array}$ & $\begin{array}{l}\text { Indicadores ligados } \\
\text { aos desembolsos } \\
\text { (Condicionantes) }\end{array}$ & $\begin{array}{l}\text { Área de } \\
\text { Resultado }\end{array}$ & Estratégia \\
\hline \multirow{4}{*}{ SETORPRIVADO } & $\begin{array}{l}\text { Simplificação dos } \\
\text { negócios }\end{array}$ & $\begin{array}{l}\text { Tempo para Abertura } \\
\text { de uma Empresa atra- } \\
\text { vés do Minas Fácil }\end{array}$ & \multirow{2}{*}{$\begin{array}{l}\text { Investimento e } \\
\text { Valor Agregado } \\
\text { da Produção }\end{array}$} & \multirow{2}{*}{$\begin{array}{l}\text { Simplificar a relação do setor pú- } \\
\text { blico com o setor privado }\end{array}$} \\
\hline & $\begin{array}{l}\text { Simplificação dos } \\
\text { negócios }\end{array}$ & $\begin{array}{l}\text { Implementação do Mi- } \\
\text { nas Fácil em todo o } \\
\text { estado }\end{array}$ & & \\
\hline & $\begin{array}{l}\text { Parcerias público- } \\
\text { privadas (PPPs) }\end{array}$ & $\begin{array}{l}\text { Número de projetos de } \\
\text { PPPs contratados }\end{array}$ & - & - \\
\hline & $\begin{array}{l}\text { Rede de inovação } \\
\text { e tecnologia }\end{array}$ & $\begin{array}{l}\text { Núcleos de Inovação } \\
\text { Tecnológica }\end{array}$ & $\begin{array}{l}\text { Inovação, Tecno- } \\
\text { logia e Qualidade }\end{array}$ & $\begin{array}{l}\text { Fortalecer a rede de inovação } \\
\text { tecnológica em todo o território } \\
\text { mineiro }\end{array}$ \\
\hline \multirow{3}{*}{ SAÚDE } & $\begin{array}{l}\text { Regionalização } \\
\text { dos serviços de } \\
\text { saúde }\end{array}$ & $\begin{array}{l}\text { Percentual de hospitais } \\
\text { do programa PROHOSP } \\
\text { formalmente avaliados } \\
\text { para acreditação pela } \\
\text { ONA }\end{array}$ & \multirow{3}{*}{ Vida Saudável } & $\begin{array}{l}\text { Intensificar o processo de regio- } \\
\text { nalização da Atenção à Saúde, } \\
\text { para, progressivamente, adequar } \\
\text { a oferta e a qualidade da atenção } \\
\text { de média e alta complexidade às } \\
\text { necessidades da população }\end{array}$ \\
\hline & - & $\begin{array}{l}\text { Implementação de um } \\
\text { sistema padronizado } \\
\text { de custos em hospitais } \\
\text { da FHEMIG }\end{array}$ & & $\begin{array}{l}\text { Aumentar a eficiência alocativa e a } \\
\text { otimização do sistema de atenção } \\
\text { à saúde. }\end{array}$ \\
\hline & Saúde em Casa & $\begin{array}{l}\text { Estudo de impacto dos } \\
\text { Centros Viva Vida }\end{array}$ & & $\begin{array}{l}\text { Universalizar a oferta para a popu- } \\
\text { lação SUS dependente e ampliar a } \\
\text { qualidade dos serviços de atenção } \\
\text { primária à saúde, com ênfase em } \\
\text { ações de promoção, prevenção e } \\
\text { assistência à saúde da família }\end{array}$ \\
\hline \multirow{4}{*}{ EDUCAÇÃO } & $\begin{array}{l}\text { Alfabetização no } \\
\text { Tempo Certo }\end{array}$ & $\begin{array}{l}\text { Percentual de alunos } \\
\text { da rede estadual em } \\
\text { nível recomendável de } \\
\text { leitura no } 3^{\circ} \text { ano do EF }\end{array}$ & \multirow{3}{*}{$\begin{array}{l}\text { Educação de Qua- } \\
\text { lidade }\end{array}$} & $\begin{array}{l}\text { Reduzir a taxa de distorção idade/ } \\
\text { série }\end{array}$ \\
\hline & $\begin{array}{l}\text { Sistema de Avalia- } \\
\text { ção da Rede Pú- } \\
\text { blica de Educação } \\
\text { Básica - PROEB }\end{array}$ & $\begin{array}{l}\text { Programa de Avaliação } \\
\text { da Aprendizagem Es- } \\
\text { colar }\end{array}$ & & $\begin{array}{l}\text { A construção de sistemas de ava- } \\
\text { liação, com o objetivo de verificar } \\
\text { periodicamente a qualidade do } \\
\text { ensino em todas as escolas de } \\
\text { Minas Gerais e subsidiar a gestão } \\
\text { escolar orientada para resultados* }\end{array}$ \\
\hline & - & $\begin{array}{l}\text { Sistema de Informações } \\
\text { Custo-Aluno (SICA) }\end{array}$ & & $\begin{array}{l}\text { Promover um salto na escolari- } \\
\text { dade média da população, for- } \\
\text { mada em um sistema eficiente, } \\
\text { com altos níveis de equidade e } \\
\text { orientado por padrões internacio- } \\
\text { nais de custo e qualidade }\end{array}$ \\
\hline & $\begin{array}{l}\text { Educação profis- } \\
\text { sionalizante }\end{array}$ & $\begin{array}{l}\text { Estudantes matricula- } \\
\text { dos em cursos de en- } \\
\text { sino médio profissio- } \\
\text { nalizante }\end{array}$ & $\begin{array}{l}\text { Protagonismo Ju- } \\
\text { venil }\end{array}$ & $\begin{array}{l}\text { Ampliar a oferta e melhorar a } \\
\text { qualidade do Ensino Profissiona- } \\
\text { lizante* }^{*}\end{array}$ \\
\hline
\end{tabular}

(continua...) 
(continuação)

\begin{tabular}{|c|c|c|c|c|}
\hline \multicolumn{3}{|c|}{$\begin{array}{c}\text { Segunda Parceria para o Desenvolvimento } \\
\text { de Minas Gerais (2008) }\end{array}$} & \multicolumn{2}{|c|}{$\begin{array}{l}\text { Plano Mineiro de Desenvolvimento Integrado } \\
\qquad(2007-2023)\end{array}$} \\
\hline $\begin{array}{l}\text { Áreas apoiadas } \\
\text { pelo empréstimo }\end{array}$ & $\begin{array}{l}\text { Projetos } \\
\text { estratégicos }\end{array}$ & $\begin{array}{l}\text { Indicadores ligados } \\
\text { aos desembolsos } \\
\text { (Condicionantes) }\end{array}$ & $\begin{array}{c}\text { Área de } \\
\text { Resultado }\end{array}$ & Estratégia \\
\hline \multirow{4}{*}{$\begin{array}{l}\text { INFRAESTRUTURA } \\
\text { RODOVIÁRIA }\end{array}$} & $\begin{array}{l}\text { ProMG Pleno - } \\
\text { Recuperação e } \\
\text { manutenção de } \\
\text { rodovias }\end{array}$ & $\begin{array}{l}\text { Percentual da malha } \\
\text { rodoviária estadual pa- } \\
\text { vimentada com contra- } \\
\text { tos de manutenção e } \\
\text { reabilitação por resul- } \\
\text { tado no Pró-MG Pleno }\end{array}$ & \multirow{4}{*}{$\begin{array}{l}\text { Logística de Inte- } \\
\text { gração e Desen- } \\
\text { volvimento }\end{array}$} & $\begin{array}{l}\text { Reduzir os custos de transportes } \\
\text { e ampliar o acesso a mercados da } \\
\text { produção mineira, através da ofer- } \\
\text { ta de uma malha viária suficiente, } \\
\text { adequada e segura }\end{array}$ \\
\hline & Pro-Acesso & $\begin{array}{l}\text { Percentual médio de } \\
\text { atraso das obras de } \\
\text { pavimentação do Pró- } \\
\text { Acesso concluídas no } \\
\text { ano corrente }\end{array}$ & & $\begin{array}{l}\text { Superar gargalos e melhorar a qua- } \\
\text { lidade da infraestrutura de trans- } \\
\text { portes, para ampliar a inserção } \\
\text { competitiva da economia mineira } \\
\text { e o desenvolvimento das regiões } \\
\text { de baixo dinamismo }\end{array}$ \\
\hline & ProSeg & $\begin{array}{l}\text { Número de equipa- } \\
\text { mentos eletrônicos de } \\
\text { controle de velocidade }\end{array}$ & & $\begin{array}{l}\text { Reduzir os custos de transportes } \\
\text { e ampliar o acesso a mercados da } \\
\text { produção mineira, através da ofer- } \\
\text { ta de uma malha viária suficiente, } \\
\text { adequada e segura }\end{array}$ \\
\hline & Pro-Acesso & $\begin{array}{l}\text { Percentual de muni- } \\
\text { cípios no estado com } \\
\text { acesso pavimentado }\end{array}$ & & $\begin{array}{l}\text { Superar gargalos e melhorar a qua- } \\
\text { lidade da infraestrutura de trans- } \\
\text { portes, para ampliar a inserção } \\
\text { competitiva da economia mineira } \\
\text { e o desenvolvimento das regiões } \\
\text { de baixo dinamismo }\end{array}$ \\
\hline \multirow{3}{*}{$\begin{array}{l}\text { QUALIDADE } \\
\text { AMBIENTAL } \\
\text { E SOCIAL }\end{array}$} & $\begin{array}{l}\text { Implementação } \\
\text { do SISEMA Móvel } \\
\text { e qualificação de } \\
\text { pessoal }\end{array}$ & $\begin{array}{l}\text { Tempo médio para a } \\
\text { concessão de licença } \\
\text { ambiental (LI e LO para } \\
\text { as classes } 3 \text { e 4) para } \\
\text { atividades com impac- } \\
\text { to ambiental no estado. }\end{array}$ & $\begin{array}{l}\text { Qualidade Ambi- } \\
\text { ental }\end{array}$ & $\begin{array}{l}\text { Adotar metas de sustentabilidade } \\
\text { e qualidade ambiental e consolidar } \\
\text { o sistema de monitoramento }\end{array}$ \\
\hline & Saúde Indígena & $\begin{array}{l}\text { Número de equipes } \\
\text { interdisciplinares para } \\
\text { saúde indígena finan- } \\
\text { ciadas pela SES }\end{array}$ & - & - \\
\hline & $\begin{array}{l}\text { Educação Indíge- } \\
\text { na }\end{array}$ & $\begin{array}{l}\text { Número de professores } \\
\text { certificados no Curso } \\
\text { de Magistério Indígena }\end{array}$ & - & - \\
\hline
\end{tabular}

(continua...) 
(continuação)

\begin{tabular}{|c|c|c|c|c|}
\hline \multicolumn{3}{|c|}{$\begin{array}{c}\text { Segunda Parceria para o Desenvolvimento } \\
\text { de Minas Gerais (2008) }\end{array}$} & \multicolumn{2}{|c|}{$\begin{array}{l}\text { Plano Mineiro de Desenvolvimento Integrado } \\
\qquad(2007-2023)\end{array}$} \\
\hline $\begin{array}{l}\text { Áreas apoiadas } \\
\text { pelo empréstimo }\end{array}$ & $\begin{array}{l}\text { Projetos } \\
\text { estratégicos }\end{array}$ & $\begin{array}{l}\text { Indicadores ligados } \\
\text { aos desembolsos } \\
\text { (Condicionantes) }\end{array}$ & $\begin{array}{l}\text { Área de } \\
\text { Resultado }\end{array}$ & Estratégia \\
\hline \multirow{5}{*}{$\begin{array}{l}\text { ALIVIO DA POBRE- } \\
\text { ZA RURAL }\end{array}$} & $\begin{array}{l}\text { Projeto de Comba- } \\
\text { te à Pobreza Rural }\end{array}$ & $\begin{array}{l}\text { Número de famílias be- } \\
\text { neficiadas pelo PCPR } \\
\text { (iniciando em 2010) }\end{array}$ & $\begin{array}{l}\text { Desenvolvimento } \\
\text { do Norte de Mi- } \\
\text { nas, Jequitinho- } \\
\text { nha, Mucuri e Rio } \\
\text { Doce }\end{array}$ & $\begin{array}{l}\text { Desenvolver a produção local, com } \\
\text { ênfase na formação profissional, } \\
\text { na alfabetização, no empreende- } \\
\text { dorismo e no acesso a mercados }\end{array}$ \\
\hline & $\begin{array}{l}\text { Projeto de Comba- } \\
\text { te à Pobreza Rural }\end{array}$ & $\begin{array}{l}\text { Monitoramento inten- } \\
\text { sivo do PCPR }\end{array}$ & - & - \\
\hline & - & $\begin{array}{l}\text { Melhoria nos dados } \\
\text { de pobreza de Minas } \\
\text { Gerais }\end{array}$ & $\begin{array}{l}\text { Qualidade e Ino- } \\
\text { vação em Gestão } \\
\text { Pública }\end{array}$ & $\begin{array}{l}\text { Ampliar, agilizar e dinamizar o } \\
\text { sistema de estatísticas de MG, para } \\
\text { que se tenham informações tem- } \\
\text { pestivas e de qualidade, capazes } \\
\text { de fornecer subsídios para tomada } \\
\text { de decisão* }\end{array}$ \\
\hline & $\begin{array}{l}\text { Educação profis- } \\
\text { sionalizante }\end{array}$ & $\begin{array}{l}\text { Número de escolas do } \\
\text { Ensino Médio no Gran- } \\
\text { de Norte que oferecem } \\
\text { cursos de formação pro- } \\
\text { fissional de montagem e } \\
\text { manutenção de compu- } \\
\text { tadores }\end{array}$ & $\begin{array}{l}\text { Protagonismo Ju- } \\
\text { venil }\end{array}$ & $\begin{array}{l}\text { Ampliar a oferta e melhorar a } \\
\text { qualidade do Ensino Profissiona- } \\
\text { lizante* }^{*}\end{array}$ \\
\hline & - & $\begin{array}{l}\text { Proporção de nascidos } \\
\text { vivos de mães com } 7 \\
\text { ou mais consultas de } \\
\text { pré-natal no Grande } \\
\text { Norte }\end{array}$ & Vida Saudável & $\begin{array}{l}\text { Reduzir a mortalidade materno- } \\
\text { infantil. }\end{array}$ \\
\hline
\end{tabular}

* Não é apresentado como um dos objetivos estratégicos, mas como um meio para atingi-los.

Fonte: Minas Gerais, 2007; World Bank, 2008b, elaboração própria.

Dentre todos os projetos estratégicos apoiados pela parceria, apenas três não constavam de forma explicita no PMDI, as parcerias público-privadas e as ações de saúde e educação indígena. Vale ressaltar, entretanto, que as PPPs constavam no PMDI 2003-2020, mas foram retiradas na revisão do ano de 2007.

Dessa maneira, pode-se afirmar que a Segunda Parceria representou a consolidação da relação entre os dois atores em termos econômicos e de cooperação técnica. Fica evidente que o Banco Mundial e o governo do estado de Minas Gerais possuíam objetivos e estratégias de desenvolvimento compatíveis. O que nos remete à questão da seletividade, apresentada na seção anterior. 


\section{A Terceira Parceria para o Desenvolvimento de Minas Gerais}

A Terceira Parceria para o Desenvolvimento de Minas Gerais é o último empréstimo do período analisado. Firmada no final de 2012, teve como objetivo “auxiliar o Governo de Minas Gerais a aprofundar o seu modelo de gestão inovador, reforçar a sua gestão orçamentária e sua gestão de políticas setoriais nas áreas de inclusão social, gestão ambiental e governança metropolitana” (WORLD BANK, 2012b, p. 34).

O empréstimo buscou apoiar quatro áreas de resultados, sendo elas: o fortalecimento da gestão pública e orçamentária; a promoção da inclusão social; a melhoria da sustentabilidade ambiental; e o desenvolvimento de uma estrutura de governança metropolitana. Dentro de cada área, foram definidos um ou mais objetivos de desenvolvimento. E, assim como nos empréstimos anteriores, as áreas apoiadas são compatíveis com os objetivos estratégicos traçados pelo governo. Segundo o BIRD, “[a] operação baseia-se na estratégia e nas prioridades do Governo, como refletido em seu plano multianual de desenvolvimento integrado [sic] (PMDI), no seu plano plurianual (PPA) e em outros documentos de setores específicos” (WORLD BANK, 2012b, p. 38).

Para financiar tais áreas, a operação disponibilizou para Minas Gerais US\$ 450 milhões por meio de um DPL. A nova parceria possuía um desembolso único no valor total da operação, o que pode demonstrar uma maior confiança do BIRD no estado. Isto porque, nesse tipo de empréstimo, o poder de coerção do credor, caso o programa de reformas não seja devidamente implementado, é menor, uma vez que todo o recurso já está em poder do mutuário.

A realização de um desembolso único não significou, porém, a inexistência de condicionantes ao empréstimo. O banco e o Estado acordaram dez ações que deveriam ser cumpridas pelo Estado previamente à efetivação do empréstimo, que, no geral, eram constituídas pela criação de assessorias, comitês, decretos, resoluções, entre outros, considerados vitais para o sucesso da parceria (WORLD BANK, 2012b). O Quadro 3, apresentado abaixo, ilustra a aderência entre as ações prévias (condicionantes ex ante) de cada área apoiada pelo empréstimo e as estratégias delineadas no PMDI 2011-2030. 


\section{Quadro 3. Comparativo entre a Terceira Parceria para o Desenvolvimento de Minas Gerais (2012) e o Plano Mineiro de Desenvolvimento Integrado 2011-2030}

\begin{tabular}{|c|c|c|c|}
\hline \multicolumn{2}{|c|}{$\begin{array}{c}\text { Terceira Parceria para o Desenvolvimento } \\
\text { de Minas Gerais (2012) }\end{array}$} & \multicolumn{2}{|c|}{$\begin{array}{l}\text { Plano Mineiro de Desenvolvimento Integrado } \\
\qquad(2011-2030)\end{array}$} \\
\hline Objetivos & $\begin{array}{l}\text { Ações Prévias ao Desembolso do } \\
\text { Empréstimo (Condicionantes) }\end{array}$ & Área de Resultado & Estratégias Prioritárias \\
\hline \multicolumn{4}{|c|}{ Área 1. Fortalecimento do Setor Público e Gestão Orçamentária } \\
\hline $\begin{array}{l}\text { 1.1 Aumentar a ro- } \\
\text { bustez e susten- } \\
\text { tabilidade do } \\
\text { Modelo de Ges- } \\
\text { tão Baseada em } \\
\text { Resultados }\end{array}$ & $\begin{array}{l}\text { 1. O Mutuário: (i) estabeleceu } 22 \text { As- } \\
\text { sessorias de Gestão Estratégica e } \\
\text { Inovação com vistas a descentralizar } \\
\text { as funções de gestão baseada em } \\
\text { resultados do Mutuário [...] }\end{array}$ & \multirow{3}{*}{$\begin{array}{l}\text { Rede de Governo } \\
\text { Integrado, Eficiente } \\
\text { e Eficaz }\end{array}$} & $\begin{array}{l}\text { Acentuar a orientação da estratégia } \\
\text { governamental para as entregas e } \\
\text { os resultados para a sociedade. } \\
\text { Cultivar um ambiente propício } \\
\text { e desenvolver instrumentos que } \\
\text { estimulem a geração, a adoção e } \\
\text { a disseminação de inovações na } \\
\text { gestão pública. }\end{array}$ \\
\hline \multirow[b]{2}{*}{$\begin{array}{l}\text { 1.2 Aumentar a pre- } \\
\text { visibilidade e o } \\
\text { controle da exe- } \\
\text { cução orçamen- } \\
\text { tária }\end{array}$} & $\begin{array}{l}\text { 2. O Mutuário adotou o Módulo de } \\
\text { Programação Orçamentária do Sis- } \\
\text { tema Integrado de Administração } \\
\text { Financeira - SIAFI/MG [...] }\end{array}$ & & \multirow[b]{2}{*}{$\begin{array}{l}\text { Aumentar a qualidade e a produ- } \\
\text { tividade do gasto setorial, com } \\
\text { ênfase na melhoria da composição } \\
\text { estratégica do gasto e no aumento } \\
\text { da aderência do orçamento à es- } \\
\text { tratégia de desenvolvimento do } \\
\text { Estado }\end{array}$} \\
\hline & $\begin{array}{l}\text { 3. O Mutuário adotou medidas para } \\
\text { avaliar projetos de valor superior a } \\
\text { R\$ } 5 \text { milhões e cofinanciados através } \\
\text { de Transferências Voluntárias pelo } \\
\text { Garantidor, efetuadas no território } \\
\text { do Mutuário antes de apresentar tais } \\
\text { projetos à Câmara de Coordenação } \\
\text { Geral, Planejamento, Gestão e Finan- } \\
\text { ças para aprovação [...] }\end{array}$ & & \\
\hline $\begin{array}{l}\text { 1.3 Aumentar a par- } \\
\text { ticipação cidadã na } \\
\text { definição de priori- } \\
\text { dades regionais }\end{array}$ & $\begin{array}{l}\text { 4. O Mutuário: (i) criou dois comi- } \\
\text { tês regionais no seu território, um } \\
\text { para a região Norte de Minas e um } \\
\text { para a região do Rio Doce, para } \\
\text { implementar em caráter piloto um } \\
\text { processo participativo para aumentar } \\
\text { a participação da sociedade. }\end{array}$ & $\begin{array}{l}\text { Rede de Governo } \\
\text { Integrado, Eficiente } \\
\text { e Eficaz }\end{array}$ & $\begin{array}{l}\text { Ampliar os espaços públicos ins- } \\
\text { titucionalizados voltados para a } \\
\text { construção participativa de políti- } \\
\text { cas públicas estaduais }\end{array}$ \\
\hline \multicolumn{4}{|c|}{ Área 2. Promoção da Inclusão Social } \\
\hline \multirow{2}{*}{$\begin{array}{l}\text { 2.1 Reduzir a po- } \\
\text { breza nas áreas } \\
\text { mais desfavo- } \\
\text { recidas, a fim } \\
\text { de reduzir a } \\
\text { exclusão e as } \\
\text { desigualdades } \\
\text { regionais }\end{array}$} & $\begin{array}{l}\text { 5. O Mutuário, através da SEDESE: } \\
\text { (i) estabeleceu o Piso Mineiro [da } \\
\text { Assistência Social] [...] }\end{array}$ & \multirow{2}{*}{$\begin{array}{l}\text { Rede de Desenvol- } \\
\text { vimento Social e } \\
\text { Proteção }\end{array}$} & $\begin{array}{l}\text { Universalizar o Piso Mineiro de } \\
\text { Assistência Social, por meio de } \\
\text { compartilhamento financeiro da } \\
\text { infraestrutura da rede de assistên- } \\
\text { cia social, em complementaridade } \\
\text { aos recursos federais e municipais }\end{array}$ \\
\hline & $\begin{array}{l}\text { 6. O Mutuário alterou a regulamentação } \\
\text { sobre o Programa Travessia de forma } \\
\text { a incluir, entre outras disposições, } \\
\text { uma que prevê a realização pelo } \\
\text { Mutuário de um diagnóstico sobre } \\
\text { educação, saúde e qualidade de vida } \\
\text { nos municípios selecionados [...] }\end{array}$ & & $\begin{array}{l}\text { Identificar a população em extre- } \\
\text { ma pobreza e direcionar ações de } \\
\text { desenvolvimento social para supe- } \\
\text { ração do estado de pobreza }\end{array}$ \\
\hline
\end{tabular}


(continuação)

\begin{tabular}{|c|c|c|c|}
\hline \multicolumn{2}{|c|}{$\begin{array}{c}\text { Terceira Parceria para o Desenvolvimento } \\
\text { de Minas Gerais (2012) }\end{array}$} & \multicolumn{2}{|c|}{$\begin{array}{l}\text { Plano Mineiro de Desenvolvimento Integrado } \\
\qquad(2011-2030)\end{array}$} \\
\hline Objetivos & $\begin{array}{l}\text { Ações Prévias ao Desembolso do } \\
\text { Empréstimo (Condicionantes) }\end{array}$ & Área de Resultado & Estratégias Prioritárias \\
\hline \multicolumn{4}{|c|}{ Área 2. Promoção da Inclusão Social } \\
\hline $\begin{array}{l}\text { 2.2 Fortalecimento } \\
\text { da gestão da edu- } \\
\text { cação }\end{array}$ & $\begin{array}{l}\text { 7. O Mutuário adotou e está imple- } \\
\text { mentando um processo de seleção } \\
\text { baseado no mérito para superinten- } \\
\text { dentes escolares regionais e diretores } \\
\text { escolares do seu território [...] }\end{array}$ & $\begin{array}{l}\text { Rede de Educação } \\
\text { e Desenvolvimento } \\
\text { Humano }\end{array}$ & $\begin{array}{l}\text { Desenvolver a capacidade gerencial } \\
\text { dos diretores das escolas públicas } \\
\text { por meio da seleção baseada em } \\
\text { critérios de mérito e liderança, da } \\
\text { avaliação e premiação por resulta- } \\
\text { dos, da interligação dos profissio- } \\
\text { nais em rede e da certificação ocu- } \\
\text { pacional dos gestores educacionais }\end{array}$ \\
\hline \multicolumn{4}{|c|}{ Área 3. Melhoria da Sustentabilidade Ambiental } \\
\hline \multirow{2}{*}{$\begin{array}{l}\text { 3.1 Aumentar a ca- } \\
\text { pacidade do } \\
\text { Estado de fazer } \\
\text { frente aos desa- } \\
\text { fios ambientais }\end{array}$} & $\begin{array}{l}\text { 8. O Mutuário estabeleceu, dentro de } \\
\text { sua Secretaria de Meio Ambiente e } \\
\text { Desenvolvimento Sustentável, uma } \\
\text { Subsecretaria de Gestão e Regula- } \\
\text { rização Ambiental e uma Subse- } \\
\text { cretaria de Controle e Fiscalização } \\
\text { Ambiental [...] }\end{array}$ & $\begin{array}{l}\text { Rede de Desenvol- } \\
\text { vimento Econômico } \\
\text { Sustentável }\end{array}$ & $\begin{array}{l}\text { Conferir maior agilidade e efetivi- } \\
\text { dade ao licenciamento ambiental* }\end{array}$ \\
\hline & $\begin{array}{l}\text { 9. O Mutuário adotou medidas para in- } \\
\text { centivar o plantio de florestas em seu } \\
\text { território com o objetivo de fornecer } \\
\text { matéria-prima para as indústrias nele } \\
\text { localizadas }[\ldots]\end{array}$ & - & - \\
\hline \multicolumn{4}{|c|}{ Área 4. Desenvolvimento de uma estrutura de governança metropolitana } \\
\hline $\begin{array}{l}4.1 \text { Fortalecer a Go- } \\
\text { vernança Me- } \\
\text { tropolitana para } \\
\text { permitir a coor- } \\
\text { denação de polí- } \\
\text { ticas públicas es- } \\
\text { taduais e muni- } \\
\text { cipais na Região } \\
\text { Metropolitana de } \\
\text { Belo Horizonte } \\
\text { (RMBH) }\end{array}$ & $\begin{array}{l}\text { 10. O Mutuário, através do Conse- } \\
\text { lho Deliberativo de Desenvolvi- } \\
\text { mento da Região Metropolitana de } \\
\text { Belo Horizonte, adotou um plano } \\
\text { diretor de desenvolvimento regional } \\
\text { integrado para a região metropolita- } \\
\text { na de Belo Horizonte [...]. }\end{array}$ & Rede de Cidades & $\begin{array}{l}\text { Induzir e apoiar a formulação } \\
\text { de planos regionais estratégicos } \\
\text { para as regiões do estado com a } \\
\text { participação da população local, } \\
\text { bem como estimular e assessorar } \\
\text { a formação de consórcios públicos } \\
\text { intermunicipais, nos casos per- } \\
\text { tinentes, e fortalecer os arranjos } \\
\text { metropolitanos }\end{array}$ \\
\hline
\end{tabular}

Fonte: MINAS GERAIS, 2011; WORLD BANK, 2012b, elaboração própria. 


\section{Conclusões}

A hipótese que se buscou verificar no presente trabalho era a de que o Banco Mundial, mediante o atrelamento da liberação de recursos ao cumprimento de certas condicionantes definidas em contrato, conseguiria influenciar a definição da estratégia de desenvolvimento do Estado e, consequentemente, o processo de construção de políticas públicas.

Constatamos, entretanto, que houve um forte alinhamento entre as condicionantes estipuladas e os objetivos e estratégias previamente definidos pelo Estado. Isso foi verificado pelo fato de que grande parte das ações financiadas e suas condicionantes, em geral, constavam no PMDI como uma estratégia ou um objetivo estratégico de desenvolvimento.

O alto nível de alinhamento demonstrou que a hipótese inicial desse trabalho não era válida, já que, se o banco buscasse influenciar significativamente a estratégia de desenvolvimento do Estado, veríamos condicionantes que não convergiriam com os objetivos e estratégias apresentados no PMDI. Diante disso, concluímos que o Banco Mundial, devido à própria evolução de sua estratégia de atuação, quando se afasta das políticas prescritivas do Consenso de Washington e se volta para o apoio de programas elaborados internamente pelos países financiados, levando em conta os critérios de seletividade e ownership, não se utiliza das condicionantes para interferir na estratégia de desenvolvimento do estado de Minas Gerais. O critério de seletividade é essencial para entender essa situação. Como o banco passa a utilizá-lo para definir quais Estados apoiar, e decide por firmar uma parceria com Minas Gerais, isto significa que ele considera a estratégia de desenvolvimento do estado, traduzida em seu programa de reformas, sólida.

Isso não significa, porém, que o Banco Mundial não tenha influenciado a estratégia de desenvolvimento de Minas Gerais, apenas que as condicionantes não foram o mecanismo utilizado para fazê-lo. A aquiescência de diversos países às orientações do Consenso, o Brasil incluso, possibilitou a incorporação (ao menos em parte) das novas diretrizes para o desenvolvimento nos moldes propostos pelas agências interestatais internacionais. É possível que a seletividade tenha criado um incentivo para que o governo do estado de Minas Gerais criasse um plano de desenvolvimento com estratégias compatíveis àquelas favorecidas pelo Banco Mundial, visando ter acesso aos empréstimos junto ao banco. Autores como Koeberle (2003) e Morrow (2005) apontam que a seletividade pode incentivar potenciais mutuários a fingir ter ownership sobre um conjunto de políticas indicadas pelo banco. Tal hipótese deve ser testada em um estudo futuro. 


\section{Referências}

ANCOCHEA, Diego Sánchez. El modelo económico en América Latina desde los años noventa hasta la Gran Crisis: ¿Um modelo razonable o un fracaso liberal? Revista CIDOB d'Afers Internacionals, n. 85/86, Los Retos de América Latina en un Mundo en Cambio, maio 2009, p. 133-155. Disponível em: < http://www.jstor.org/ stable/40586390 > . Acesso em: 07 de mar. 2017.

BÉJAR, Ramón Casilda. El 'consenso de Washington'. Política Exterior, v. 16, n. 86, mar.-abr. 2002, p. 109-117, 119-124, 127-128. Disponível em: < http://www.jstor. org/stable/20645248 > . Acesso em: 07 mar. 2017.

BRESSER-PEREIRA, Luiz Carlos. A teoria do desenvolvimento econômico e a crise de identidade do Banco Mundial. Revista de Economia Política, São Paulo, v. 15, n. 1, jan.-mar. 1995. p. 5-40.

CHIARI, Mirna S. As atuais funções do Banco Mundial no contexto dos ajustes estruturais no Brasil. Belo Horizonte. Dissertação (mestrado). Escola de Governo Professor Paulo Neves de Carvalho da Fundação João Pinheiro. 2000.

CLEMENS, Michael A. e KREMER, Michael. The New Role for the World Bank. The Journal of Economic Perspectives, v. 30, n. 1, inverno 2016, p. 53 - 76. Disponível em: < http://www.jstor.org/stable/43710010 > . Acesso em: 03 mar. 2017.

CYPHER, James M. The Slow Death of the Washington Consensus on Latin America. Latin American Perspectives, Issue 103, vol. 25. N 6. Nov. 1998. p. 47-51.

DRAZEN, Allan. Conditionality and ownership in IMF lending: A political economy approach. In: RANIS, Gustav (ed.); VREELAND, James R. (ed.); KOSACK, Stephen (ed.). Globalization and the Nation State: The impact of the IMF and the World Bank. Nova York: Routledge. 2006. Cap. 3, p. 51-81.

DREHER, Axel. A Public Choice Perspective of IMF and World Bank Lending and Conditionality. Public Choice, Nova York, v. 119, n. 3/4, jun. 2004. p. 445-464.

ENNS, Charis. Knowledges in competition: Knowledge discourse at the World Bank during the Knowledge for Development era. Global Social Policy, v. 15, n. ${ }^{\circ}$ 1, 2015, p. 61-80.

FINE, Ben; LAPAVITSAS, Costas; PINCUS, Jonathan (Eds.). Development Policy in the Twenty-fist Century - Beyond the post-Wahington Consensus. London, Routledge. 2001.

GATTI, Marcos. Sobre o Conceito de Políticas Públicas e suas Consequências para a Orientação Profissional. São Paulo. Tese (doutorado). Instituto de Psicologia da Universidade de São Paulo. 2011.

KATZ, Claudio. Dualities of Latin America. Latin American Perspectives, Issue 203, vol. 42. $\mathrm{N}^{\circ}$ 4. Nov. 2015. p. 10-42.

KOEBERLE, Stefan G. Should Policy-Based Lending Still Involve Conditionality? The World Bank Research Observer, Oxford, v. 18, n. 2, outono. 2003. p. 249-273. 
LICHTENSZTEJN, Samuel. Fondo Monetario Internacional y Banco Mundial: instrumentos del poder financiero. Xalapa, México: Universidad Veracruzana. 2010.

MARANGOS, John. The Evolution of the Anti-Washington Consensus Debate: From 'Post-Washington Consensus' to 'After the Washington Consensus'. Competition \& Change, vol. 12, No 3. Sep. 2008. p. 227-244.

MINAS GERAIS. Secretaria de Estado de Planejamento e Gestão. Plano Mineiro de Desenvolvimento Integrado (PMDI) 2011-2030. Belo Horizonte, 2011. 151 p.

MINAS GERAIS. Secretaria de Estado de Planejamento e Gestão. Plano Mineiro de Desenvolvimento Integrado (PMDI) 2007-2023. Belo Horizonte, 2007. 49 p.

MINAS GERAIS. Secretaria de Estado de Planejamento e Gestão. Plano Mineiro de Desenvolvimento Integrado (PMDI) 2003-2020. Belo Horizonte, 2003. 125 p.

MONTIEL, Héctor Cuadra. Incompleteness of Post-Washington Consensus: A Critique of Macro-economic and Institutional Reforms. International Studies, Vol. 44, $\mathrm{n}^{\circ} 2$. 2007. p. 103-122.

MORROW, Daniel. Adjusting conditionality: prescriptions for policy-based lending. In: KOEBERLE, Stefan (ed.); BEDOYA, Harold (ed.); SILARKY, Peter (ed.); VERHEYEN, Gero (ed.), Conditionality revisited: concepts, experiences, and lessons, Washington: World Bank, 2005. Cap. 21, p. 197-223.

PALONI, Alberto; ZANARDI, Maurizio. Development Policy Lending, conditionality and ownership: a political economy model. CREDIT Research Paper, Nottingham, n. 10, nov. 2005.

RANIS, Gustav. Ownership, Dutch Disease and the World Bank. In: RANIS, Gustav (ed.); VREELAND, James Raymond (ed.); KOSACK, Stephen (ed.). Globalization and the Nation State: The impact of the IMF and the World Bank. Nova York: Routledge. 2006. Cap. 16, p. 419-426.

RAVALLION, Martin. The World Bank: Why It Is Still Needed and Why It Still Disappoints. The Journal of Economic Perspectives, v. 30, n. 1, inverno 2016. p. 77-94. Disponível em: http://www.jstor.org/stable/43710011. Acesso em: 03 mar. 2017.

RODRIK, Dani. Goodbye Washington Consensus, hello Washington confusion? A review of the World Bank's Economic Growth in the 1990s: Learning from a Decade of Reform. Journal of Economic Literature, Pittsburgh, v. 44, n. 4, dez. 2006. p. 973-987. RUGER, Jennifer Prah. The Changing Role of the WORLD BANK in Global Health. American Journal of Public Health, Washington, v. 95, n. 1, jan. 2005. p. 60-70.

SACHS, Jeffrey D. Conditionality, Debt Relief, and the Developing Country Debt Crisis. In: SACHS, Jeffrey D. (ed), Developing Country Debt and Economic Performance: The International Financial System. Chicago: The University of Chicago Press. 1989. Cap. 14, p. 275-284. 
SANTISO, Carlos. Good Governance and Aid Effectiveness: The World Bank and Conditionality. The Georgetown Public Policy Review, Washington, v. 7, n. 1, outono, 2001. p. 1-22.

SANTOS JUNIOR, Raimundo B. dos. As políticas sociais do Banco Mundial para os países em desenvolvimento. Campinas. Tese (doutorado). Instituto de Filosofia e Ciências Humanas, Universidade Estadual de Campinas, Campinas. 2010.

STIGLITZ, Joseph. Is there a Post-Washington Consensus Consensus?. In: NARCÍS, Serra (ed.); STIGLITZ, Joseph (ed.), The Washington Consensus Reconsidered. Oxford: Oxford University Press. 2008. Cap. 4, p. 41-56.

STIGLITZ, Joseph. The World Bank at the Millennium. The Economic Journal, Oxford, n. 109, nov. 1999. p. 577-597.

WILliAMSON, John. The Washington Consensus as Policy Prescription for Development. In: Practitioners of Development, 2004, Washington. Anais... Washington, 2004. Disponível em < https://piie.com/publications/papers/williamson0204.pdf > . Acesso em: 05 mar. 2017.

WORLD BANK. International Bank for Reconstruction and Development. World Bank. 2014. Disponível em: < http://go.worldbank.org/65RBCJ2IW0 > . Acesso em: 06 jun. 2014. WORLD BANK. Brasil - Terceiro Programa de Parceria para o desenvolvimento do Estado de Minas Gerais, Washington. 2012.

WORLD BANK. The importance of stakeholder ownership for capacity development results, Washington, 2011.

WORLD BANK. Brazil - Additional Financing for the Second Minas Gerais Partnership (SWAP) Project, Washington. 2010.

WORLD BANK. Brazil - Second Minas Gerais Partnership (SWAP) Project, Washington. 2008. WORLD BANK. Brazil - Minas Gerais Partnership for Development Project, Washington. 2006. WORLD BANK. Economic Growth in the 1990s: Learning from a Decade of Reform, Washington, 2005a.

WORLD BANK. Review of World Bank conditionality: legal aspects of conditionality in policy-based lending, Washington, 2005b.

WORLD BANK. World Bank history. World Bank. (s.d.). Disponível em: < http://go.world bank.org/W3SF2UKO71 > . Acesso em: 06 jun. 2014. 


\title{
Comunidades de Relações Internacionais na América Latina: uma análise das tendências a partir do TRIP 2014
}

\author{
International Relations Communities in Latin \\ America: an analysis of trends from TRIP 2014
}

DOI: $10.21530 /$ ci.v12n1.2017.553

\author{
Rafael Duarte Villa ${ }^{1}$ \\ Arlene B. Tickner ${ }^{2}$ \\ Marília Carolina B. Souza ${ }^{3}$ \\ Yamile Carolina Cepeda Másmela ${ }^{4}$
}

\section{Resumo}

Este relatório tem por objetivo divulgar as principais tendências verificadas nos resultados do Projeto Teaching. Research \& Internacional Policy (TRIP), de 2014, entre as comunidades epistêmicas latino-americanas da Argentina, Brasil, Chile, Colômbia e México. Os resultados do relatório referem-se às preferências que estas comunidades apresentam quanto ao seu formato, opções metodológicas e epistemológicas; percepções quanto à dominação norte-americana da área e; por fim, suas impressões sobre política internacional.

Palavras-chave: TRIP, América Latina, Comunidades Epistêmicas, Tendências.

\begin{abstract}
This report aims to disclose the main trends observed in the results of the Project "Teaching. Research \& International Policy” (TRIP), of 2014, among the Latin American epistemic communities of Argentina, Brazil, Chile, Colombia and Mexico. The results of the report refer to the preferences of these communities regarding their format, methodological and epistemological options, perceptions regarding the North American domination of the field and, finally, their impressions on international politics.

Key-words: TRIP, Latin America, Epistemic Communities, Tendencies.

1 Professor Associado de Relações internacionais na Universidade de São Paulo (Brasil). E-mail: rafaelvi@usp.br

2 Professora titular do Departamento de Ciência Política da Universidad del Rosario (Colômbia). E-mail: arleneb.tickner@urosario.edu.co

3 Professora Doutora da Universidade Anhembi Morumbi (Brasil).E-mail: profa.marilia.csouza@gmail.com

4 Professora Assistente na Pontificia Universidade Javeriana (Colombia). E-mail: carocep@gmail.com

Artigo submetido em 24/09/2016 e aprovado em 31/01/2017.
\end{abstract}




\section{Introdução}

O presente relatório tem por objetivo divulgar para o meio acadêmico em geral as principais tendências verificadas nos resultados do projeto Teaching Research and International Policy (TRIP) de 2014 (MALINIAK et al.) para os países da América Latina: Argentina, Brasil, Chile, Colômbia e México. Os resultados se referem a percepções em torno da comunidade epistêmica latino-americana de Relações Internacionais, quanto ao seu formato, preferências metodológicas, epistemológicas, percepções quanto à dominação norte-americana da área e impressões sobre política internacional.

O projeto TRIP (MALINIAK et al.) está em curso desde 2004, é sediado pelo Institute for the Theory and Practice of International Relations da William \& Mary College e hoje contempla mais de 33 países. O TRIP busca, por meio de um survey enviado a acadêmicos e docentes de Relações Internacionais dos cinco continentes, o qual contempla uma série de questões, respondidas de forma voluntária, conhecer mais a fundo, a partir do olhar dos acadêmicos, as comunidades de relações internacionais e suas perspectivas globais. $\mathrm{O}$ objetivo é, sobretudo, encontrar relações entre o processo de ensino e o desenvolvimento de pesquisa e, por conseguinte, qual a possível influência que a comunidade epistêmica pode exercer sobre a política externa de seu país, e quais as percepções desta comunidade epistêmica sobre a política internacional. A última versão do TRIP foi aplicada em 2014 e a próxima será em 2017. Ainda em 2014, foram incluídos no survey 32 países, já com os cinco latino-americanos mencionados acima, os quais foram incluídos no survey ainda em 2011.

Este relatório, portanto, além de divulgar e comunicar as principais tendências para a comunidade epistêmica latino-americana de RI, possibilita refletir sobre uma possível identidade em ascensão, qual seja, em maior ou menor medida, dissonante da irradiada pelas comunidades anglo-saxônicas de relações internacionais, consideradas mainstream na disciplina de RI, bem como fornecer insumos de pesquisa à comunidade brasileira de Relações Internacionais, diante dos crescentes esforços de construir um arcabouço, tanto metodológico, quanto teórico, de reflexão sobre a área de Relações Internacionais no país e na região.

Reflexo disso foi a criação, no âmbito da Associação Brasileira de Relações Internacionais (ABRI), da sessão temática "Ensino e Pesquisa em Relações Internacionais", enquanto um espaço profícuo para debater e refletir sobre as conexões entre pesquisa e a atividade de ensino em cursos de graduação e 
pós-graduação, com seus desafios e perspectivas. Dessa forma, no $5^{\circ}$ Encontro Anual da ABRI, em 2015, organizou-se uma mesa redonda chamada "Pensando a performance das relações internacionais na América Latina: pesquisa, métodos e visões políticas a partir do Teaching, Research and International Politics 2014 (TRIP)", na qual foi possível debater os resultados do TRIP 2014 para a América Latina, e cujas reflexões tornaram premente a necessidade de redigir o presente relatório.

Assim, este documento se divide em seis seções principais, a saber: (i) o perfil das comunidades de RI latino-americanas; (ii) ensino e pesquisa; (iii) metodologias, características epistemológicas e paradigmas das comunidades; (iv) a predominância estadunidense; (v) publicações; (vi) visão dos acadêmicos sobre tendências em política internacional e, por fim, considerações finais.

\section{Perfil das comunidades de RI na América Latina}

Primeiramente, é imprescindível apresentar o universo das comunidades latino-americanas aqui abordadas. Dessa forma, como pode se observar na Tabela I abaixo, nota-se, de antemão, a superioridade, em temos numéricos, das comunidades brasileira e mexicana perante as demais:

Tabela I: Taxa de respondentes

\begin{tabular}{|ccc|}
\hline Países & Respondentes/Total & Taxa de Respostas \\
\hline Argentina & $47 / 82$ & $57 \%$ \\
Brasil & $211 / 321$ & $66 \%$ \\
Chile & $21 / 33$ & $64 \%$ \\
Colômbia & $61 / 115$ & $53 \%$ \\
México & $105 / 284$ & $37 \%$ \\
\hline
\end{tabular}

Fonte: Maliniak et al. TRIP 2014 Faculty Survey

Outro aspecto relevante a ser considerado é a alta taxa de respondentes observada, pois, com exceção do México, que apresentou uma taxa de $37 \%$ de respondentes, os outros países apresentaram taxas maiores que $50 \%$. Somando-se todos eles, apresentaram uma média de $55,4 \%$, com destaque para o Brasil, que, além de compor a maior comunidade da região em termos absolutos, apresentou a mais alta taxa de respondentes da região, com $66 \%$. 


\section{Gráfico I: Evolução do tamanho das comunidades epistêmicas por país}

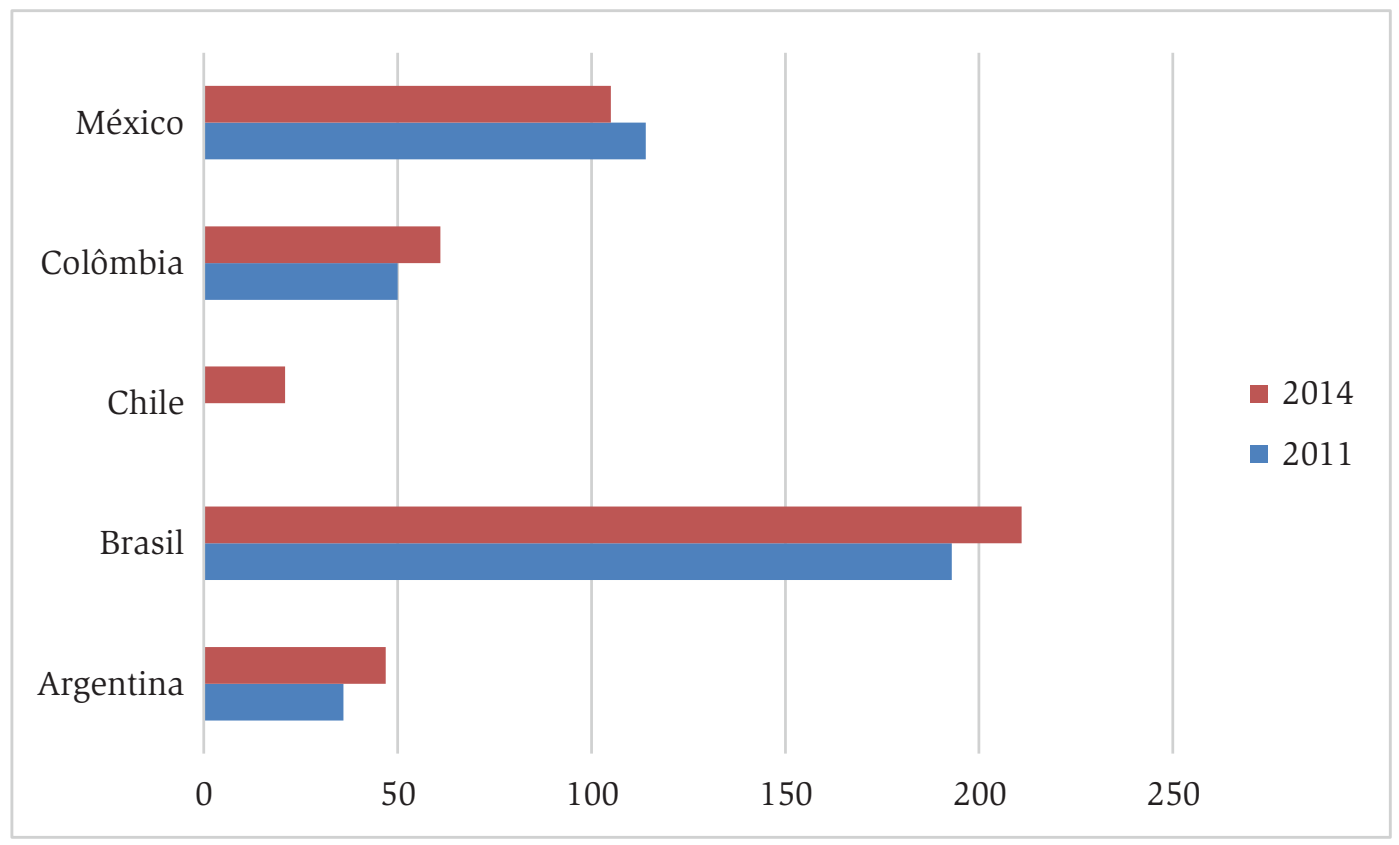

Fonte: Maliniak et al. TRIP 2014 Faculty Survey

Em adicional, é importante ressaltar que a região demonstra uma tendência de crescimento quantitativo de suas comunidades de RI, e percebe-se que a área de Relações Internacionais está em ascensão nesses países, como se observa no Gráfico I, o qual compara os anos de 2011 a 2014. Assim, ao comparar com o TRIP 2011, o que leva em conta que o Chile não participou do survey desse ano, no TRIP 2014 só a comunidade mexicana apresenta uma queda do número de membros na sua comunidade. As causas para tal crescimento podem ser diversas e se referem a questões que vão desde mecanismos mais apurados de identificação de docentes à expansão do ensino privado de relações internacionais e à formação de novos profissionais. Vale, entretanto, ressaltar que o TRIP apenas é aplicado àqueles que se dedicam à docência e à pesquisa, não sendo aplicado àqueles que somente se dedicam à pesquisa.

Tabela II: Percentual de doutores por país

\begin{tabular}{|cc|}
\hline Países & Doutorado \\
\hline Argentina & 50 \\
Brasil & 78,33 \\
Chile & 57,89 \\
Colômbia & 48,33 \\
México & 75,76 \\
\hline
\end{tabular}

Fonte: Maliniak et al. TRIP 2014 Faculty Survey 
Em termos de grau de formação educacional, o Brasil e o México têm a comunidade de doutores mais numerosa, como se observa na Tabela II acima. Da mesma forma, ambas as comunidades são as que apresentam mais membros doutores em termos absolutos. A Colômbia e a Argentina, por sua vez, são os países com menor quantidade de doutores. Em ambos os países, em termos relativos, a metade ou menos da metade da comunidade é de doutores, além do Chile, em que $57,89 \%$ da comunidade é composta por doutores. A partir desses dados, é possível inferir que existem desequilíbrios na formação de doutores entre as comunidades de RI na América Latina. Ademais, em termos gerais, é possível afirmar que existe um déficit de formação de doutores na comunidade de RI latino-americana, pois mesmo o índice do Brasil e do México, com média de $77 \%$ de doutores entre os respondentes, não é um índice satisfatório quando se considera que nos Estados Unidos o percentual de doutores é de 95,7\%, na Inglaterra é de $97,57 \%$, e na Turquia é de $93,48 \%$.

Tabela III: Percentual de homens e mulheres por país

\begin{tabular}{|cccccc|} 
& Argentina & Brasil & Chile & Colômbia & México \\
\hline Mulheres & 43,48 & 34,93 & 26,32 & 36,67 & 38,46 \\
Homens & 56,52 & 65,07 & 73,68 & 63,33 & 61,54 \\
\hline
\end{tabular}

Fonte: Maliniak et al. TRIP 2014 Faculty Survey

No que se refere ao gênero, a comunidade de relações internacionais na América Latina é fortemente masculina, pois, em média, quase dois terços pertence a esse gênero. No entanto, nesse aspecto, a comunidade latino-americana segue o mesmo padrão de gênero global. O país que apresenta uma relação de gênero mais equilibrada é a Colômbia ( 56 a $43 \%$, a favor da masculina) e o país que apresenta um maior desequilíbrio a favor do gênero masculino é o Chile $(78,63 \%)$.

\section{Tabela IV: Percentual de faixa etária por país}

\begin{tabular}{|cccccc|}
\hline & Argentina & Brasil & Chile & Colômbia & México \\
\hline$<35$ & 10,87 & 20,77 & 10,53 & 30 & 4,04 \\
$35-44$ & 36,96 & 35,27 & 31,58 & 36,67 & 25,25 \\
$45-54$ & 21,74 & 22,71 & 21,05 & 16,67 & 24,24 \\
$55-64$ & 13,04 & 13,53 & 5,26 & 15 & 31,31 \\
$65+$ & 17,39 & 7,73 & 31,58 & 1,67 & 15,15 \\
\hline
\end{tabular}

Fonte: Maliniak et al. TRIP 2014 Faculty Survey. 
Com relação à faixa etária, em torno de um terço da comunidade de RI se localiza entre 35 a 44 anos, com exceção do México, em que essa faixa responde por apenas $25,25 \%$. O México apresenta a comunidade com faixa de idade mais alta, pois um terço de sua comunidade tem entre 55 a 64 anos. No entanto, o país que apresenta a faixa etária mais idosa (mais de 65 anos) é o Chile, com 31,58\% de sua comunidade. Já a Colômbia, e em menor medida o Brasil, são os países que apresentam comunidades mais jovens (menos de 35 anos).

A comunidade de RI latino-americana é dividida quanto à sua percepção étnica. Nas comunidades argentina e chilena, uma média de $80 \%$ dos pesquisadores se considera brancos e apenas $11 \%$ se consideram mestiços. Nas comunidades colombiana e mexicana, em média, $47 \%$ se consideram brancos, e $48 \%$ se consideram mestiços. Vale ressaltar que essa questão não foi proposta pelo survey aos respondentes do Brasil.

Partindo para o campo das percepções de mundo, o survey do TRIP pergunta sobre o posicionamento ideológico dos respondentes, se é mais alinhado a percepções de esquerda ou de direita e os resultados para as comunidades latino americanas são interessantes, como pode se observar no Gráfico II:

\section{Gráfico II: Posição ideológica em assuntos econômicos e sociais}

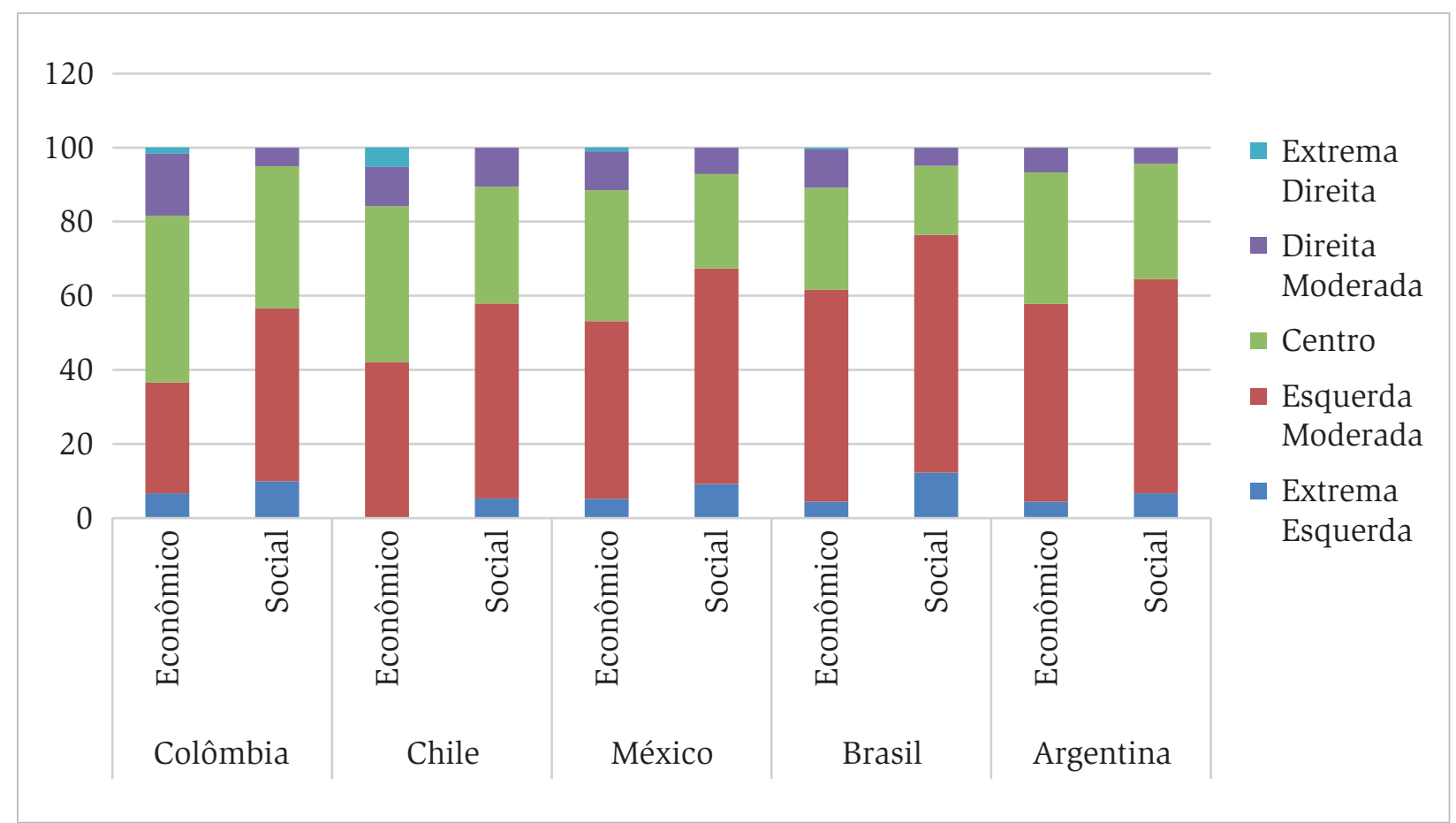

Fonte: Maliniak et al. TRIP 2014 Faculty Survey 
A partir dos resultados, foi possível afirmar que os estudiosos latino-americanos se percebem como de centro-esquerda, mesmo tendo algumas variações quanto à natureza do assunto. Por exemplo, a sua posição tende a estar mais perto do centro quando as questões são mais de natureza econômica do que sociais, como é mostrado no gráfico.

Posições radicais como “muito à direita” ou “muito à esquerda” não são comuns entre os estudiosos, ainda que haja mais respondentes que se definem como muito à esquerda do que como muito à direita, especialmente em questões sociais. Vale ressaltar que os países Argentina, Brasil e México mantém uma tendência próxima, moderada economicamente e à esquerda em assuntos sociais; já a Colômbia apresenta uma ligeira mudança, dado que em 2011 percentuais significativos (cerca de $20 \%$ ) se definiram como “um pouco à direita”, tanto nas questões econômicas e sociais, em contraste com levantamento de 2014 que mostrou $18 \%$ apenas nos aspetos econômicos; e o Chile apresenta um comportamento semelhante, exceto pelo fato de que, em questões econômicas, ninguém se tenha definido como “muito à esquerda”. O Brasil é o país em que a comunidade de RI tende a mostrar-se mais à esquerda em questões sociais (em torno de 12\%).

\section{Ensino e Pesquisa}

\section{Ensino}

Conforme aqui já foi explicitado, um dos dois pilares do projeto TRIP é a atividade de docência. O survey, nesse sentido, traz importantes insights tanto em termos de distribuição de conteúdos, e sua diferenciação para os níveis de graduação, mestrado e doutorado, quanto na busca por captar a percepção dos docentes quanto à interdisciplinaridade das relações internacionais e seus desdobramentos na condução das atividades em sala de aula. 


\section{Gráfico III: Cursos lecionados por docentes latino-americanos}

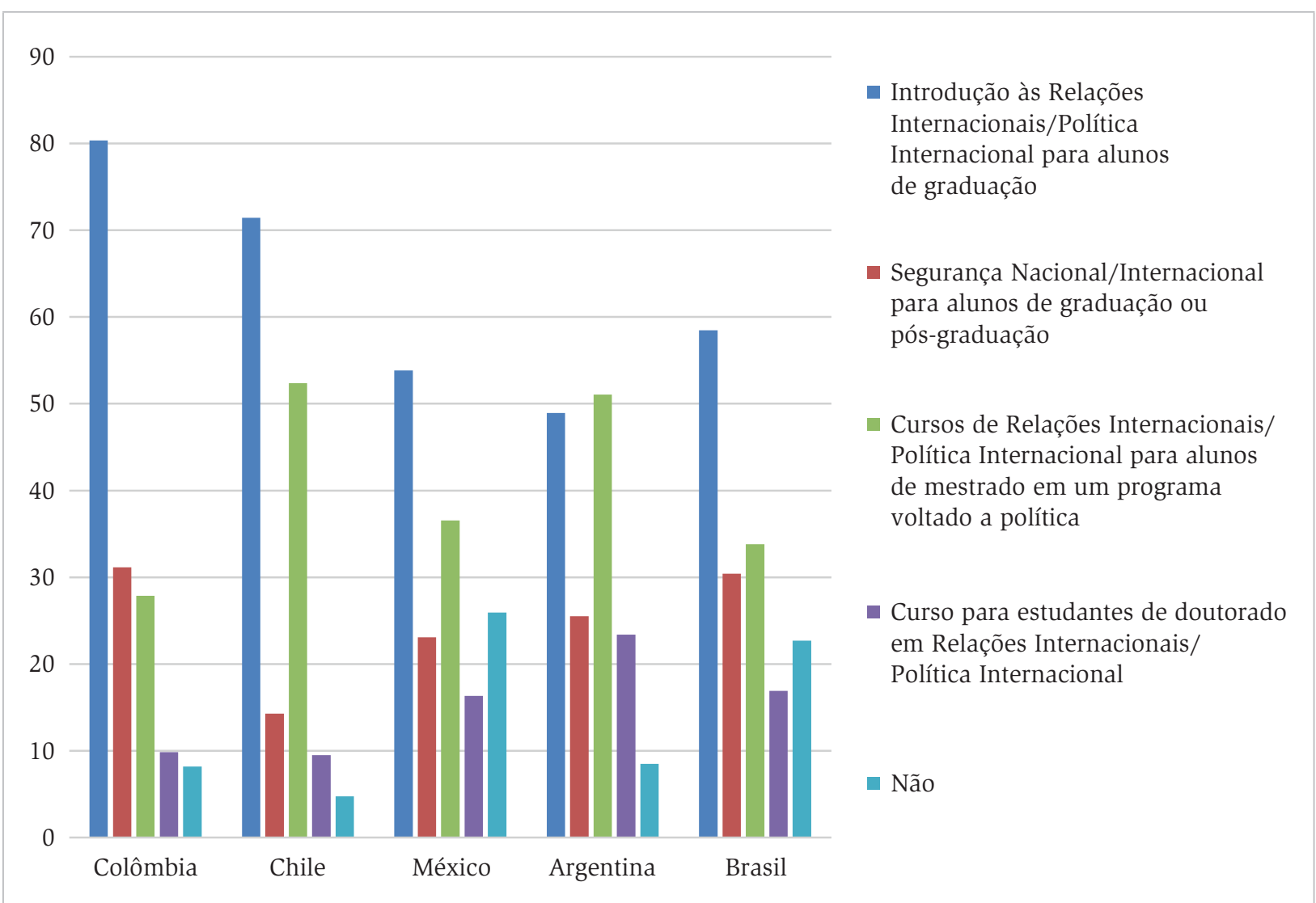

Fonte: Maliniak et al. TRIP 2014 Faculty Survey

Assim, no que se refere ao ensino, a maior parte dos pesquisadores da Colômbia e Brasil têm ensinado cursos introdutórios para Relações Internacionais para a graduação. No caso da Argentina, os entrevistados afirmam ensinar mais cursos introdutórios para o mestrado do que para a graduação.

É importante destacar que a quantidade de pesquisadores que têm ensinado em cursos de doutorado em relações internacionais ou política global tem crescido na região. Mesmo que tal índice seja menor em relação à graduação e ao mestrado, os índices para o México, Brasil e Argentina indicam que, pelo menos, 16\% de seus professores têm lecionado em cursos de doutorado sobre aquela temática, o que sugere que há um crescimento dos programas de doutorado em relações internacionais ou áreas afins na região, ou pelo menos nesses países, com destaque para a Argentina, onde esse índice ultrapassa $20 \%$. 


\section{Gráfico IV: Desenho de cursos introdutórios na graduação}

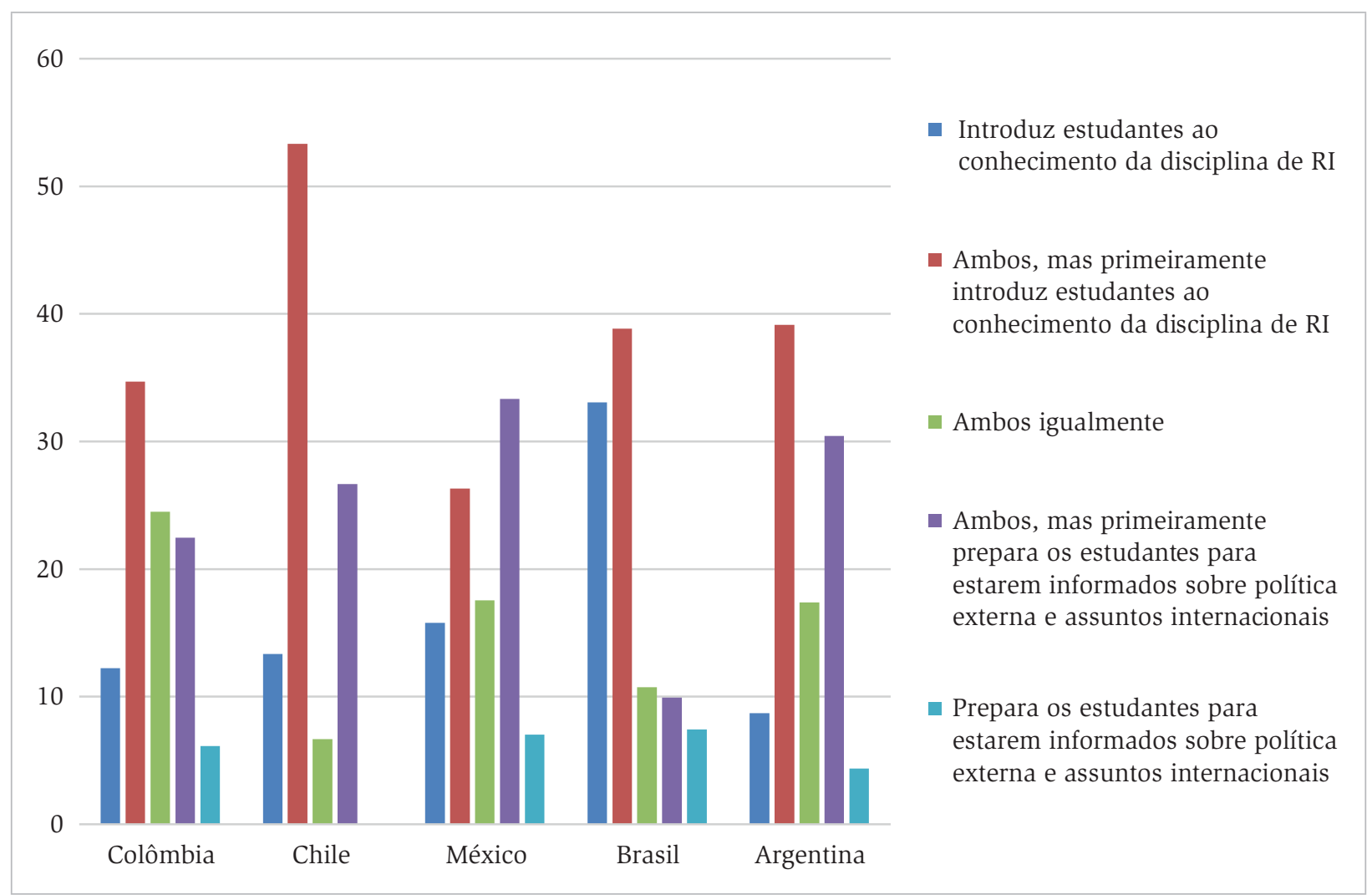

Fonte: Maliniak et al. TRIP 2014 Faculty Survey.

No que se refere à forma como as cinco comunidades organizam os cursos introdutórios de RI, há diferenças significativas entre os cursos de graduação e mestrado. No caso da graduação, conforme pode ser observado no Gráfico IV acima, a maioria dos entrevistados na Colômbia $(34,6 \%)$, Chile $(53,3 \%)$, Brasil $(38,8 \%)$ e Argentina $(39,1 \%)$ afirmam organizarem seus cursos para introduzir os alunos à disciplina e para informá-los sobre a política externa e questões internacionais, porém principalmente para apresentar-lhes a disciplina. Já os docentes mexicanos $(33,3 \%)$, por sua vez, afirmam fazerem o mesmo, porém com maior inclinação para informar os estudantes sobre temas e questões internacionais. 


\section{Gráfico V: Desenho de cursos introdutórios no Mestrado}

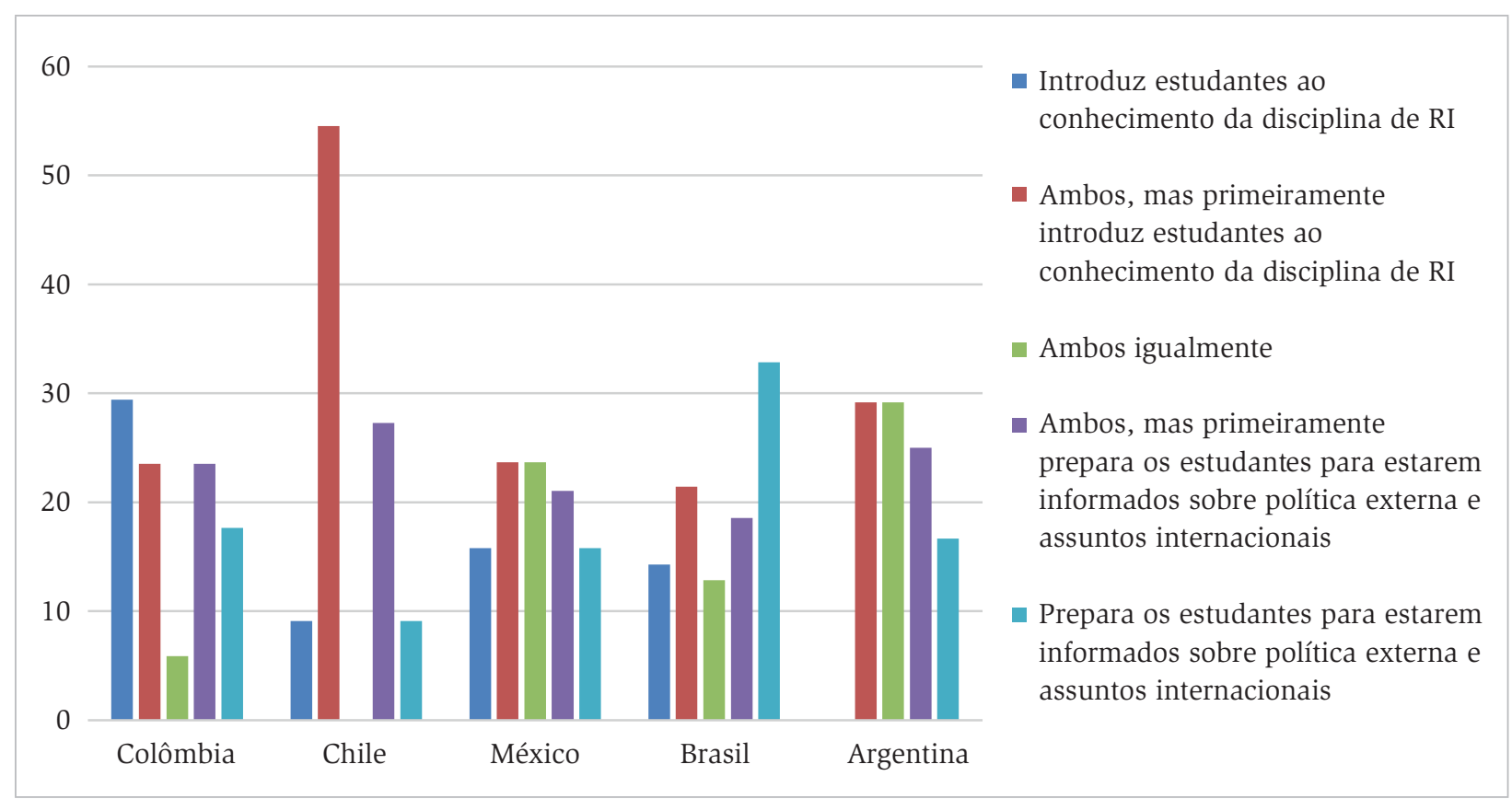

Fonte: Maliniak et al. TRIP 2014 Faculty Survey.

Já no caso dos cursos de mestrado, não parece haver consenso entre as cinco comunidades, conforme se observa no Gráfico V acima. Com relação à forma como planejam seus cursos, no caso da Colômbia, grande parte $(29,4 \%)$ da comunidade desenha os programas de forma a apresentar aos alunos a disciplina das relações internacionais, mas há um percentual significativo $(17,6 \%)$ que desenha os programas para informar os estudantes sobre questões de política externa e temas internacionais. Os pesquisadores do México são divididos quanto a tal aspecto: 23,6 \% inclinam-se a prestar a mesma atenção à formação disciplinar e questões de política internacional; e o mesmo percentual tenta manter ambos os aspectos em seus cursos, mas dando maior ênfase aos aspectos disciplinares; e um percentual significativo $(15,7 \%)$ elabora seus programas de tal maneira a apresentar aos alunos a disciplina ou para informá-los sobre política internacional.

Já no Brasil predomina uma preparação dos programas com intuito de informar os alunos sobre a política externa e questões internacionais $(32,8 \%)$, enquanto na Argentina um percentual aproximado $(29,1 \%)$ afirma que dá a mesma importância para as duas tendências, mas ligeiramente privilegia apresentar a disciplina. Por fim, os docentes do Chile $(54,5 \%)$ mantiveram o mesmo padrão que apresentaram para o nível de graduação.

Em geral, os resultados apontam que os estudiosos latino-americanos estão conscientes da importância de preparar os estudantes tanto para o exercício da 
academia quanto para a prática da política internacional. Em outras palavras, há uma percepção nessas comunidades de que deve haver uma ponte entre o mundo acadêmico e o mundo político, ambiente dos processos de tomada de decisão.

Com relação às outras disciplinas ministradas, observa-se que cursos de segurança nacional ou internacional estão entre os mais lecionados na Colômbia e no Brasil, o que poderia ser um sinal da importância desses temas nos currículos acadêmicos nesses países ou mesmo a proliferação de cursos dessa natureza poderia atentar para a importância de tais temáticas nas agendas políticas desses respectivos países.

Ademais, observa-se que nos cursos de segurança internacional são ministrados tópicos diferentes, mas ainda é possível encontrar tendências comuns de predomínio de processos, como a relação entre terrorismo, atores privados (incluindo militares) e segurança. Gênero e doença/saúde global, por seu lado, são os temas que recebem menos atenção pelas cinco comunidades. O Chile torna-se um caso interessante, pois os conteúdos mais relevantes são a inteligência, os atores privados, escassez de recursos e terrorismo (66\% em todos os casos), em contraste com questões como as alterações climáticas ou de gênero que não foram escolhidos pelos respondentes.

Mesmo que a docência em programas de doutorado seja a menos frequente entre os respondentes, o survey de 2014 incluiu uma pergunta sobre a organização do conteúdo em cursos de doutorado. E a tendência entre os estudiosos latino-americanos é de organizá-lo de acordo com paradigmas ou escolas de pensamento; no entanto, no Brasil, boa parte dos estudiosos (38,3\%) prefere fazê-lo em função de dúvidas ou problemas de pesquisa.

Nesse ínterim, apenas na Colômbia é possível encontrar um grupo significativo (16\%) que organiza o conteúdo em termos de “abordagens racionais vs. não racionais”, enquanto, no México e no Brasil (29,4\%), os docentes fazem o mesmo de acordo com os níveis de análise. Por fim, diferentes áreas temáticas também parecem ser uma forma importante de organizar cursos de doutorado na Colômbia (16,6\%), México (11,7\%), Brasil (12,2\%) e Argentina (27,2\%). 
Gráfico VI: Opinião sobre ensino de Relações Internacionais enquanto um campo interdisciplinar ou subárea da Ciência Política

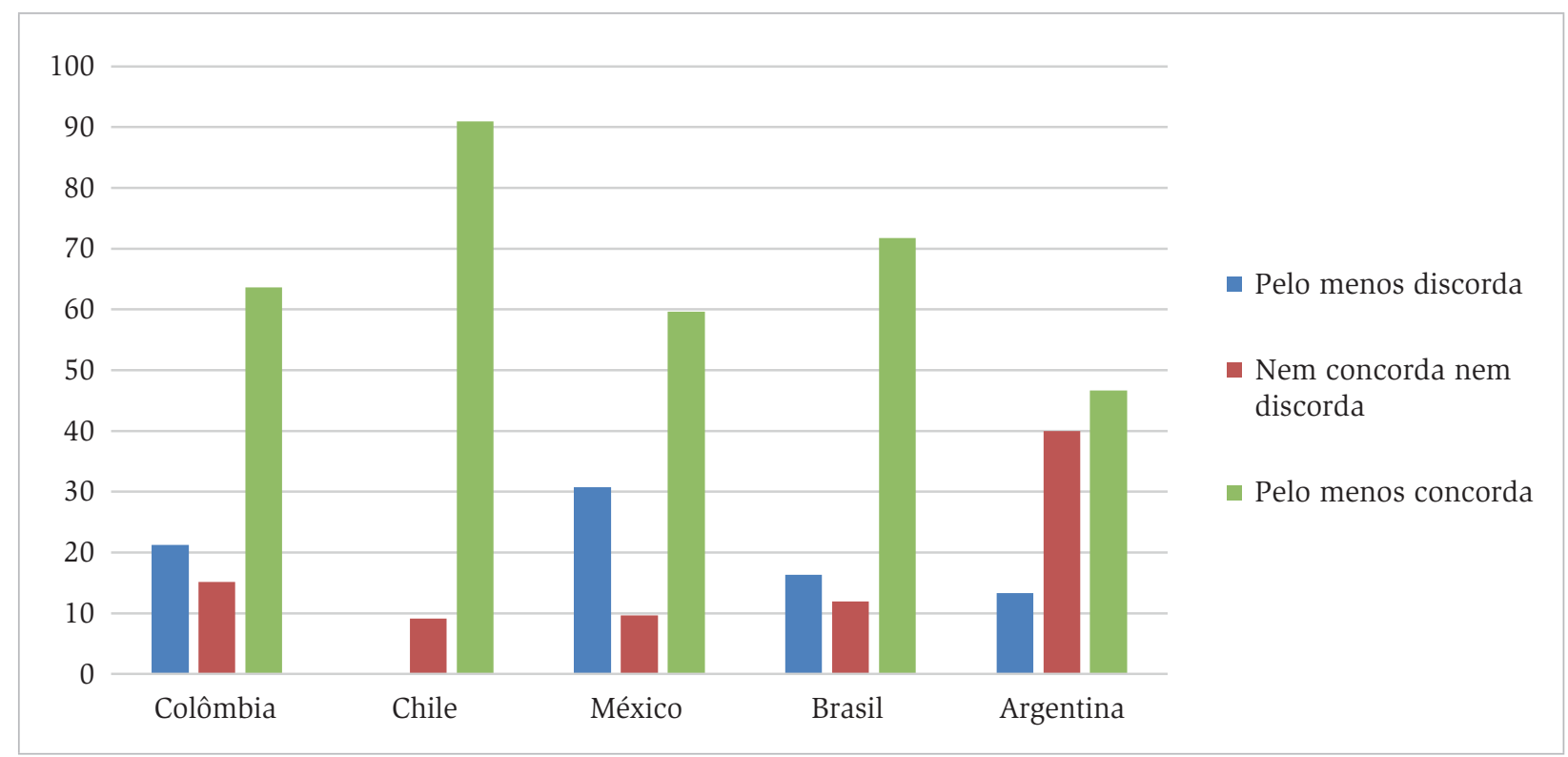

Fonte: Maliniak et al. TRIP 2014 Faculty Survey.

O survey de 2014 possibilitou uma reflexão sobre o quanto os pesquisadores consideram importante a forma como a área de relações internacionais é percebida em sua interdisciplinaridade e de que forma é organizada no nível institucional das universidades. Como pode se observar no gráfico acima, a maioria dos estudiosos, nos cinco casos, concorda com a ideia de ensinar relações internacionais como uma disciplina interdisciplinar, em vez de ensiná-la enquanto um subcampo da ciência política. O Chile, por sua vez, é o caso em que os docentes mais concordam com a interdisciplinaridade da área e o México foi o país que apresentou um maior índice de discordância com tal ideia. 
Gráfico VII: Programas de doutorado em Relações Internacionais

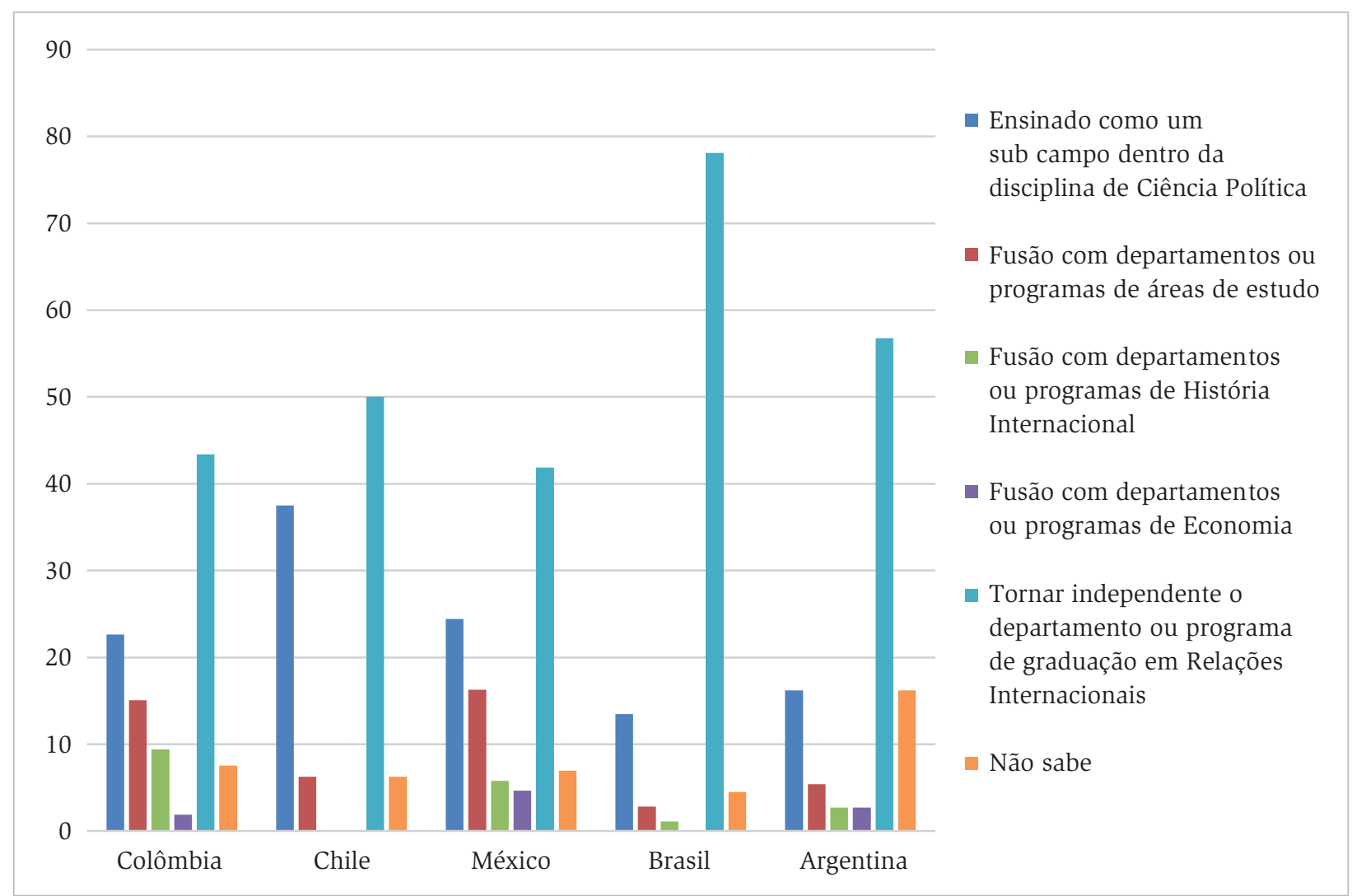

Fonte: Maliniak et al. TRIP 2014 Faculty Survey.

No âmbito dos programas de doutorado, os docentes consideram que programas de relações internacionais de tal grau deveriam tornar-se programas de departamento ou com algum grau de autonomia, com destaque para os docentes brasileiros, os quais defendem, com um percentual de quase 80\%, tal opção, segundo dados do Gráfico VII acima. A segunda opção é para que a disciplina seja ensinada como um subcampo dentro da ciência política, ao passo que a terceira possibilidade mais escolhida seria para se fundir com estudos de área de departamentos ou programas. As opções menos atrativas, em todos os casos, são mesclar-se com departamentos de economia e de história, mostrando, assim, uma forte preferência para que a área se estabeleça de forma autônoma e independente das demais, ou mesclando-se com departamentos de ciência política, como tem sido a tendência norte-americana.

\section{Pesquisa}

O segundo pilar do Projeto TRIP se refere à atividade de pesquisa. Nesse sentido, o survey buscou colher impressões diversas quanto aos temas pesquisados, 
áreas de interesse e afins, para que se possa desenhar um quadro analítico abrangente de quais temas estão mobilizando pesquisadores latino-americanos e se há convergências ou dissonâncias em tais escolhas.

Tabela V: Principais áreas e temas de pesquisa por país

\begin{tabular}{|c|c|c|c|c|c|}
\hline & Argentina & Brasil & Chile & Colômbia & México \\
\hline $\begin{array}{l}\text { Principal } \\
\text { área de } \\
\text { pesquisa }\end{array}$ & $\begin{array}{c}\text { Relações } \\
\text { Internacionais de } \\
\text { uma região/país } \\
\text { particular }\end{array}$ & $\begin{array}{c}\text { Segurança } \\
\text { Internacional/ } \\
\text { Global }\end{array}$ & $\begin{array}{c}\text { Política Externa } \\
\text { chilena }\end{array}$ & $\begin{array}{c}\text { Relações } \\
\text { Internacionais de } \\
\text { uma região/país } \\
\text { particular, } \\
\text { Teoria de } \\
\text { Relações } \\
\text { Internacionais }\end{array}$ & $\begin{array}{c}\text { Política Externa } \\
\text { Mexicana }\end{array}$ \\
\hline $\begin{array}{l}\text { Segunda } \\
\text { principal } \\
\text { área de } \\
\text { pesquisa }\end{array}$ & $\begin{array}{c}\text { Política Externa } \\
\text { Argentina }\end{array}$ & $\begin{array}{c}\text { Relações } \\
\text { Internacionais de } \\
\text { uma região/país } \\
\text { particular }\end{array}$ & $\begin{array}{c}\text { Relações } \\
\text { Internacionais de } \\
\text { uma região/país } \\
\text { particular }\end{array}$ & $\begin{array}{c}\text { Relações } \\
\text { Internacionais de } \\
\text { uma região/país } \\
\text { particular }\end{array}$ & $\begin{array}{c}\text { Relações } \\
\text { Internacionais de } \\
\text { uma região/país } \\
\text { particular }\end{array}$ \\
\hline
\end{tabular}

Fonte: Maliniak et al. TRIP 2014 Faculty Survey.

Dessa forma, quanto aos temas escolhidos, percebe-se que os interesses temáticos de investigação são diversificados nas diferentes comunidades latino-americanas, embora concentrados em um leque não muito amplo de assuntos. Quanto à principal área de estudo dentro das RIs, os pesquisadores argentinos são mais inclinados por "relações internacionais de uma determinada região ou país” com um pouco menos de atenção para temas como política externa e política externa dos Estados Unidos, teoria de Relações Internacionais ou economia política internacional. Já no caso do Brasil, segurança internacional e global é de longe a principal área de estudo, embora política externa brasileira também tenha preferência numa parte importante da comunidade de RI do país. Enquanto no Chile, os estudos de política externa do país é também de longe o principal assunto investigado em RI, seguido por teoria de Relações Internacionais, porém, em proporção menor. Na Colômbia, por sua vez, as áreas "relações internacionais de uma determinada região ou país” e teoria de Relações Internacionais dividem as duas principais escolhas da comunidade de RI daquele país. Finalmente, no caso do México, os temas de política externa, economia política internacional e "relações internacionais de uma determinada região ou país" se apresentam nessa sequência. 
Os dados sugerem que pesquisadores da região latino-americana priorizam, de modo geral, a pesquisa da política externa de seus respectivos países, o que pode sugerir ou que estejam buscando mais protagonismo e participação no debate interno sobre as políticas externas regionais ou mesmo que suas pesquisas reflitam um maior protagonismo de seu país no cenário internacional.

Quanto ao destaque que pesquisadores brasileiros dão ao tema da segurança internacional, esse pode se relacionar à maior projeção do país na política internacional, sobretudo nos últimos 15 anos, quando o país se tornou uma das dez maiores economias do mundo, período que coincidiu também com a renovação de seu aparato militar e um maior comprometimento com a segurança regional, especialmente com a forte participação em operações de paz das Nações Unidas. Tais fenômenos podem ter estimulado a comunidade local, para além de observar a política externa de seu país, a pesquisar temas de segurança internacional em geral.

\section{Gráfico VIII. Percentual dos que pesquisam América do Sul como região prioritária}

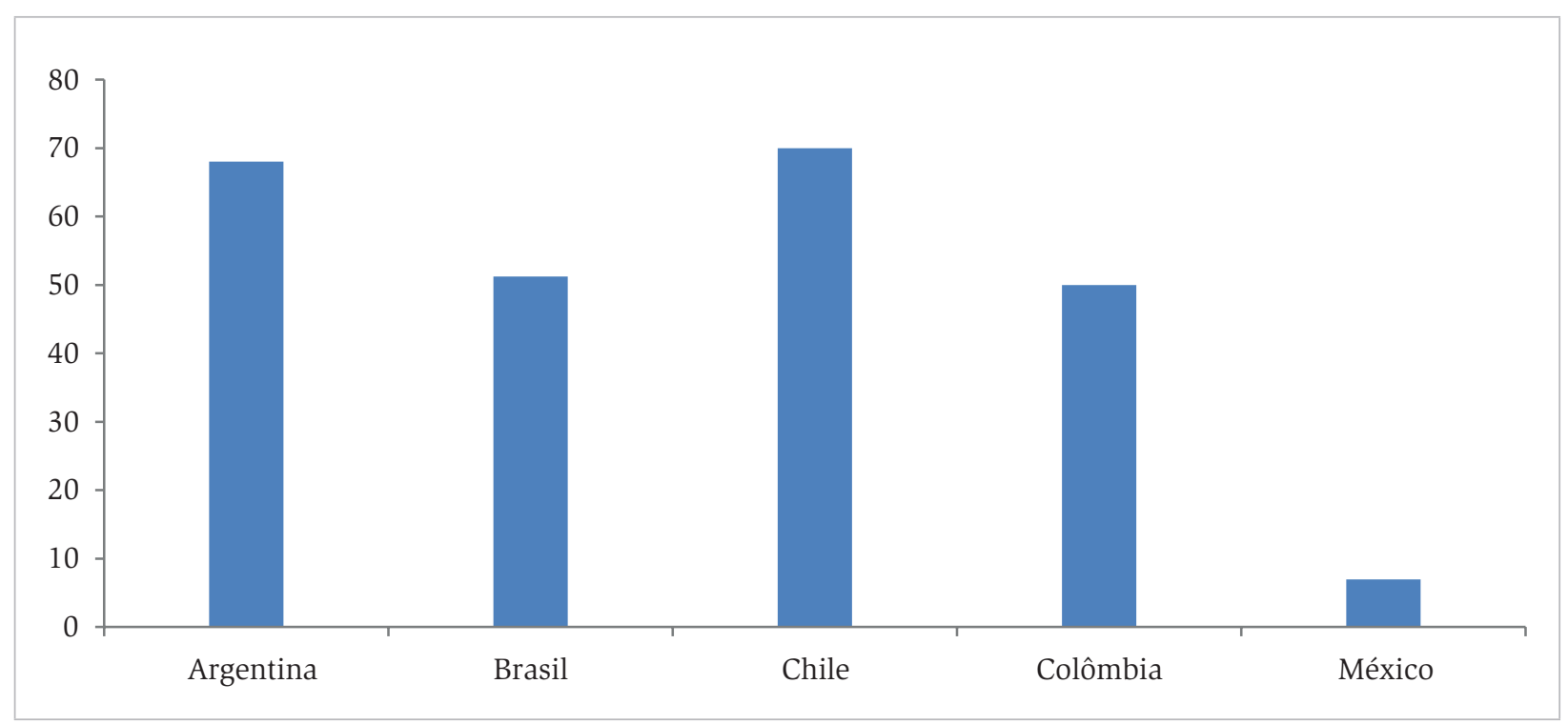

Fonte: Maliniak et al. TRIP 2014 Faculty Survey.

A maior parte das comunidades, em quase todos os países pesquisados, apresenta como principal área de estudo a América do Sul, como se observa no gráfico VIII acima, com exceção do México, cuja preferência é América do Norte (sem incluir o próprio México). A Argentina pesquisa a América do Sul num percentual de $68 \%$, o Chile e a Colômbia apresentam percentual de $70 \%$ e o Brasil um percentual de $51 \%$. Porém, inclusive no caso do México, a região 
sul-americana aparece como a primeira quando a pergunta do survey se refere a quais outras regiões (além da principal) o investigador pesquisa. Pesquisar América Latina é quase sinônimo de pesquisar América do Sul. Em casos como o Brasil e o Chile, por exemplo, regiões como América Central e Caribe apresentam índice de interesse de pesquisa de $0 \%$, ou seja, o interesse de pesquisa nessas sub-regiões é praticamente inexistente.

\section{Métodos, epistemologias e paradigmas nas comunidades latino-americanas}

O projeto TRIP possibilita uma rica reflexão no que se refere às opções metodológicas e epistemológicas ao se produzir cientificamente. O survey, nesse sentido, lança mão de importantes questionamentos quanto às opções de método, quanto ao positivismo, quanto à percepção ou não de racionalidade nos atores, e, por fim, quanto às escolhas paradigmáticas (escolas teóricas) feitas pelos acadêmicos da região. Os resultados colhidos permitem traçar um diagnóstico importante sobre qual é o estado da arte da comunidade epistêmica latinoamericana de Relações Internacionais, bem como identificar tendências futuras quanto a essas comunidades.

\section{Método}

Tabela VI: Principais métodos de pesquisa por país

\begin{tabular}{|cccccc|}
\hline & Argentina & Brasil & Chile & Colômbia & México \\
\hline Principal método & Análise & Análise & Análise & Análise & Análise \\
de pesquisa & Qualitativa & Qualitativa & Qualitativa & Qualitativa & Qualitativa \\
Segundo principal & Análise & Análise & Análise & Análise & Análise \\
método de pesquisa & Política & Política & Política & Política & Política \\
\hline
\end{tabular}

Fonte: Maliniak et al. TRIP 2014 Faculty Survey

Quanto às escolhas de método, observa-se nas cinco comunidades a opinião, bastante acentuada por sinal, de que a metodologia qualitativa é a principal ferramenta de pesquisa utilizada nas pesquisas da região. Com exceção do México e do Brasil, o restante dos países utilizam metodologias qualitativas num 
percentual que vai de $60 \%$ a $70 \%$. Um dado importante é que a metodologia de análise política (policy analysis) consegue superar a de métodos quantitativos, algo contrafatual à ideia de que atualmente existe uma forte penetração dos métodos quantitativos em comunidades de RIs do mundo em desenvolvimento.

E mais significativo ainda é constatar que o método formal (modelos formais), outro método sobre o qual recai crença de que haveria muitos adeptos na América Latina, também tem muito pouco espaço, não passando de $5 \%$ de aceitação no melhor dos casos (o Chile). Observam-se, nesse sentido, casos de comunidades que até manifestam não utilizar tais métodos (México, Colômbia e Brasil). Por fim, vale ressaltar a importância do conjunto desses dados, uma vez que se evidencia na região uma resistência ainda latente ao método quantitativo.

\section{Epistemologia}

\section{Gráfico IX: Posição quanto ao positivismo por país}

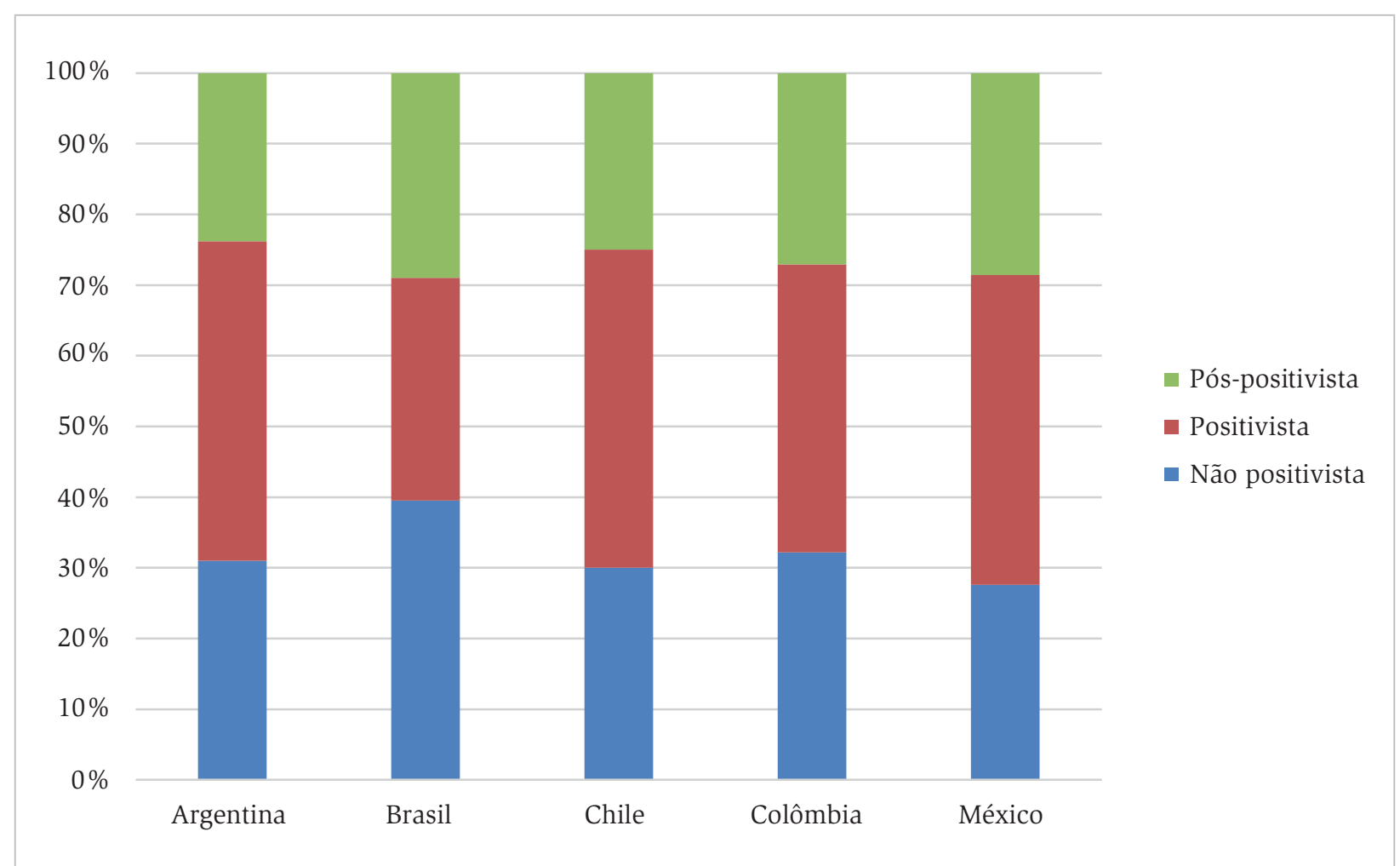

Fonte: Maliniak et al. TRIP 2014 Faculty Survey

Em termos epistemológicos, observa-se uma predominância do positivismo, como se observa no Gráfico IX. Em quatro dos países latino-americanos: Argentina, Chile, Colômbia e México, o positivismo detém a preferência majoritária. Como já havia acontecido no TRIP 2011, o Brasil se distancia dessa tendência porque é 
o único dos países em que os “não positivistas” superam os positivistas. O Brasil também se apresenta como o país com maior número de pós-positivistas (embora próximos em percentual dos outros países). No entanto, é importante sublinhar que em termos gerais os dados tendem a reforçar uma pluralidade epistemológica entre as comunidades latino-americanas de RI, isso porque a predominância positivista é equilibrada pelo alto percentual das escolhas pelo "não positivismo" e o "pós-positivismo”, pois, em geral, nas cinco comunidades, somam uma média de 55 a $60 \%$ das escolhas epistemológicas, gerando assim uma tendência a um certo hibridismo epistemológico.

\section{Gráfico X: Percentual daqueles que empregam tanto perspectivas racionalistas quanto partem de abordagens alternativas, que não se baseiam na racionalidade dos atores.}

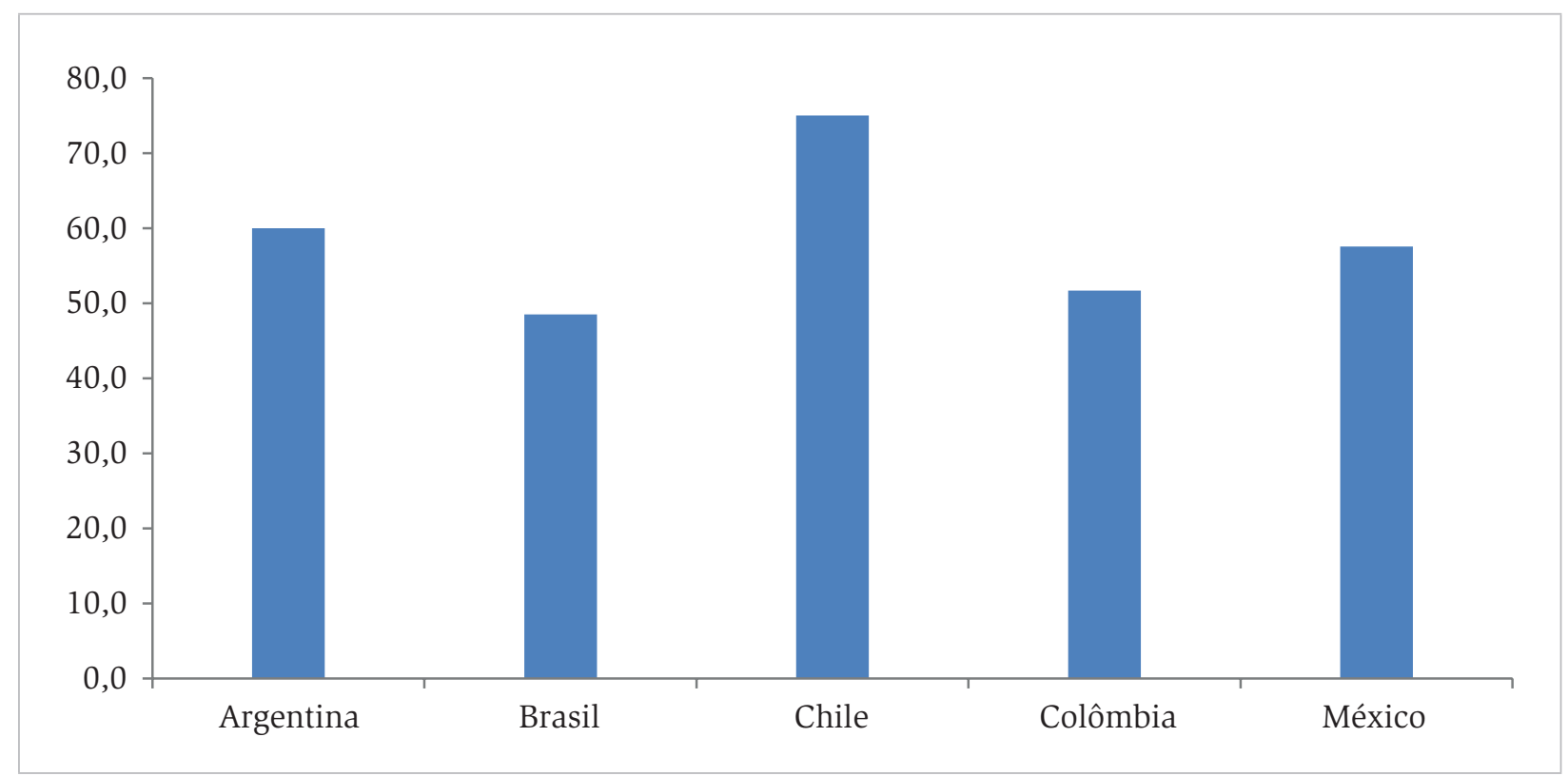

Fonte: Maliniak et al. TRIP 2014 Faculty Survey.

Nesse mesmo aspecto epistemológico, os dados parecem contrariar a percepção segundo a qual a comunidade latino-americana de RI é fortemente racionalista. Existe uma forte tendência entre as cinco comunidades em declarar (em altos índices que vão de $51 \%$ a $70 \%$ ) que suas pesquisas se baseiam tanto em pressupostos de racionalidade dos atores, bem como em abordagens alternativas, que não necessariamente assumem a racionalidade dos atores. Assim, é significativo também que, em média, quase $20 \%$ dos entrevistados na América Latina declarem que não assumem a racionalidade dos atores. Em resumo, quanto aos aspectos epistemológicos, as comunidades latino-americanas parecem seguir um padrão 
pluralista que ora se apoia na racionalidade dos atores, ora não presume a racionalidade dos mesmos.

Ademais, o survey possibilita a indicação de preferências no que tange às escolhas paradigmáticas dos acadêmicos, o que pode reforçar algumas das tendências observadas nas escolhas metodológicas e epistemológicas observadas acima.

\section{Paradigmas}

\section{Gráfico XI. Escolhas paradigmáticas atuais por país}

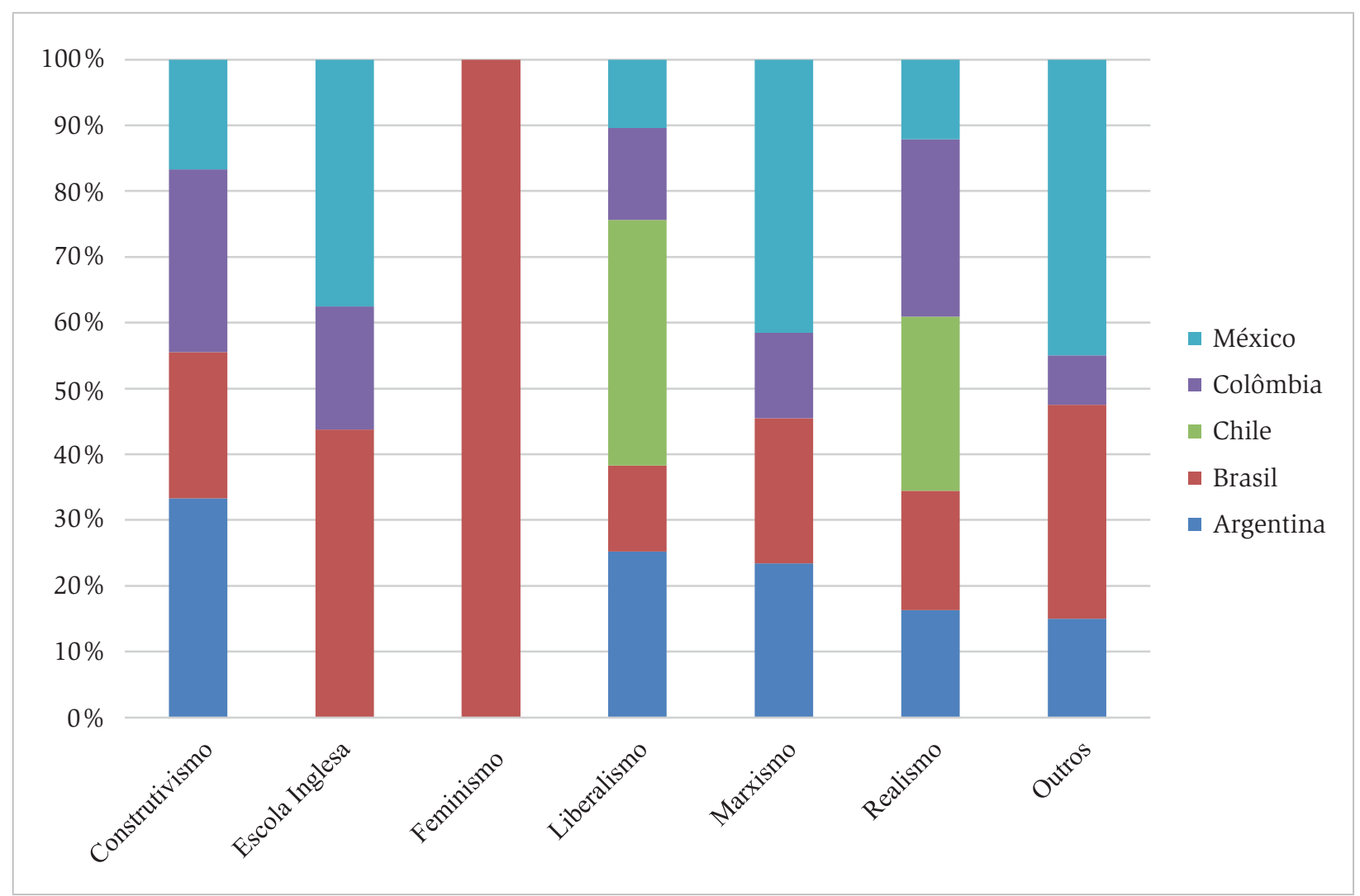

Fonte: Maliniak e al. TRIP 2014 Faculty Survey.

Em termos de paradigmas, com exceção do México e do Brasil, as comunidades de RI da América Latina se declaram majoritariamente construtivistas, como se pode verificar no Gráfico XI acima. No México, as preferências pelo realismo são levemente superiores às preferências pelo construtivismo. Porém, é importante ressaltar novamente que essas preferências construtivistas se inscrevem novamente dentro de um pluralismo paradigmático. Com exceção do Chile, o realismo continua a ter uma boa utilização entre as comunidades latino-americanas, e, em alguns casos, como Argentina e Brasil, o percentual dos que utilizam o paradigma realista não chega a estar tão distante dos que usam o paradigma construtivista. Da mesma 
forma, porém em menor medida, o liberalismo, a escola inglesa e o marxismo (este último com a exceção do Chile) têm também uma razoável aceitação.

Quanto aos paradigmas, observa-se que parece existir certo esgotamento do uso exclusivo, ou excludente, dos paradigmas. O percentual dos que afirmam "Eu não uso análise paradigmática" é relevante nas cinco comunidades, como se observa no Gráfico XI. Porém, novamente, as comunidades parecem afirmar com isso que suas análises não se atrelam necessariamente a um único paradigma.

\section{Gráfico XII: Utilização de análise paradigmática por país}

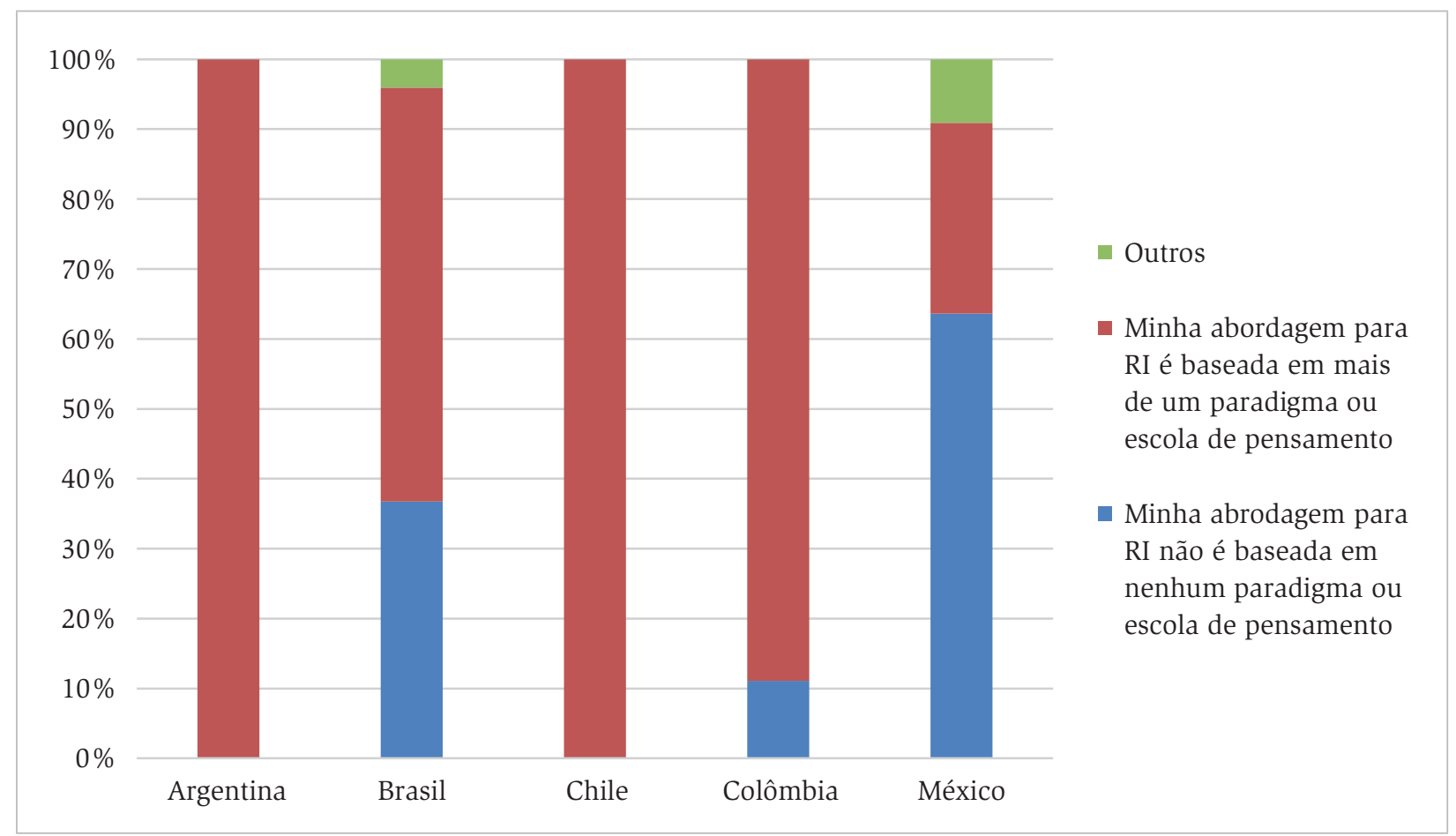

Fonte: Maliniak et al. TRIP 2014 Faculty Survey

De acordo com o Gráfico XII acima, em quatro das comunidades (com exceção do México), majoritariamente, e em altos percentuais, as respostas apontam que "Meu enfoque às RIs é baseado em mais de um paradigma ou escola de pensamento". Em alguns casos, como Argentina e Chile, $100 \%$ da comunidade adota essa posição, e, em casos, como Brasil e Colômbia, esse percentual varia de $59 \%$ a $88 \%$.

Um aspecto relevante é que, embora as comunidades tenham se afastado do uso exclusivo de paradigmas e algumas escolas tradicionais continuem a ter um bom aproveitamento nas análises, percebe-se que tem havido um processo de "migração" de escolas tradicionais de pensamento, como o realismo, liberalismo e o marxismo, para outras não tradicionais como construtivismo e escola inglesa 
ou para "outros" paradigmas; ou também, simplesmente, pesquisadores que abandonaram o paradigma tradicional, mas afirmam que "não usam análises paradigmáticas". Entre as escolas tradicionais, essa migração deu-se mais fortemente do realismo para outras escolas. Quatro das comunidades estudadas (Argentina, Brasil, Colômbia e Chile) começaram a partir de uma forte base do realismo. Sendo assim, percebe-se que, de fato, mais de uma geração de acadêmicos foi socializada inicialmente no realismo na disciplina de RI na região, conforme se observa no Gráfico XIII abaixo:

\section{Gráfico XIII: Escolhas paradigmáticas iniciais por país}

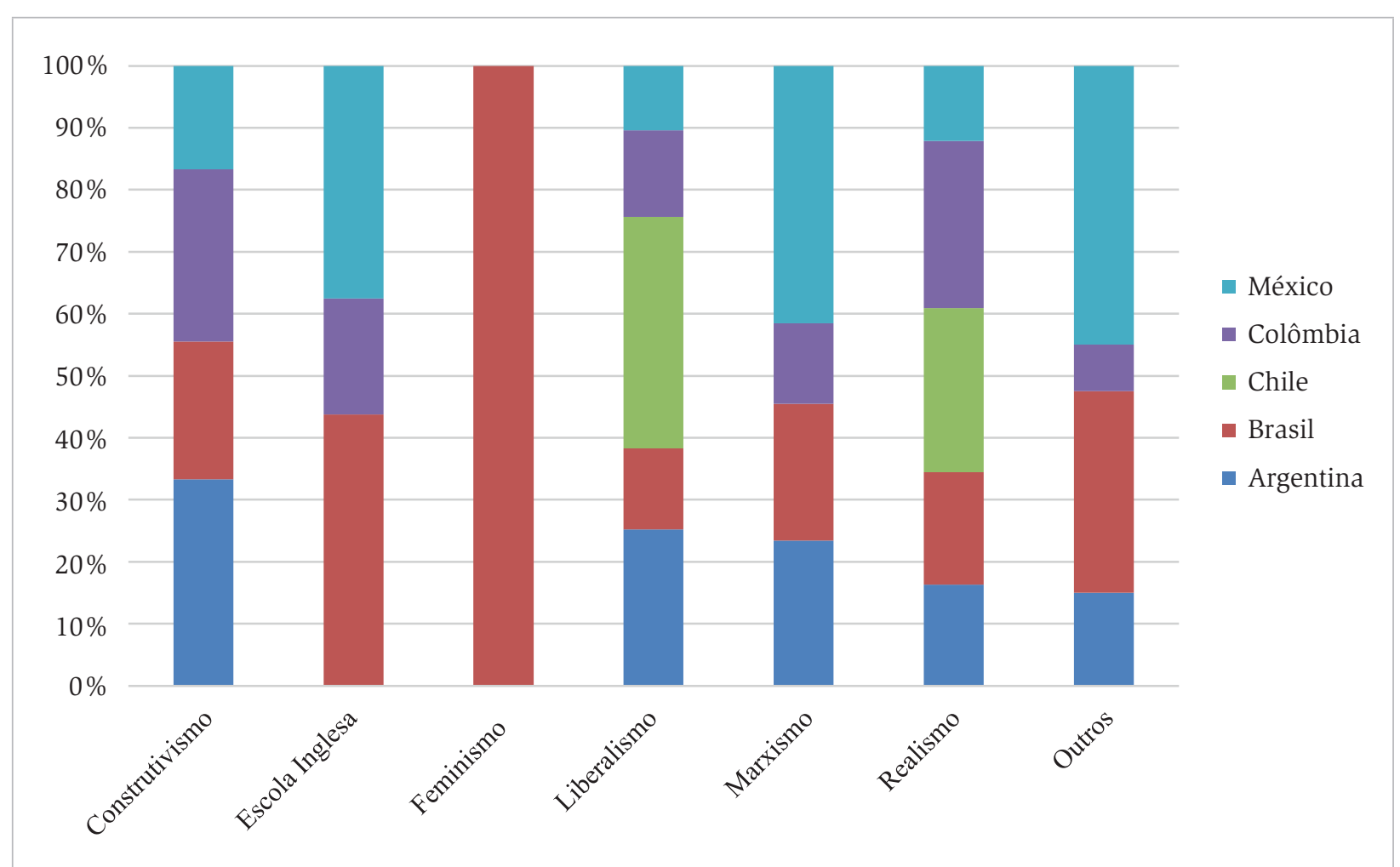

Fonte: Maliniak e al. TRIP 2014 Faculty Survey

Em média, nas cinco comunidades, mais de $27 \%$ dos membros pesquisadores mudaram de paradigma, embora isso seja mais forte em países como Colômbia e México, onde quase um terço da comunidade mudou de paradigma. Também é significativo que, apesar da forte orientação que prevalece na disciplina para o uso de paradigmas, quase um quarto da comunidade latino-americana afirma que nunca usou paradigma de análise. Tal constatação não é irrelevante, pois pode nos levar à seguinte reflexão: análises mais sofisticadas poderiam dispensar o uso de paradigmas? 


\section{A Influência Estadunidense na Disciplina}

O survey do TRIP 2014 questionou os acadêmicos a respeito do fecundo debate inaugurado em finais da década de 1970 por Stanley Hoffman e que se referia ao fato de a disciplina de Relações Internacionais ser ou não uma disciplina dominada basicamente pela produção, paradigmas e metodologias norte-americanos.

Nos resultados, percebe-se novamente uma dissonância entre os países, especialmente no que se refere à posição do Brasil, e, em alguma medida, à posição do México, como se pode verificar na tabela VII:

\section{Tabela VII: Perspectiva sobre a dominância dos Estados Unidos na disciplina por país}

\begin{tabular}{|cccccc} 
& Argentina & Brasil & Chile & Colômbia & México \\
\hline Discordo fortemente & 9,09 & 22,77 & 0 & 5,88 & 4,65 \\
Discordo & 13,64 & 57,43 & 9,09 & 8,82 & 32,56 \\
Não discordo nem concordo & 22,73 & 1,98 & 9,09 & 11,76 & 13,95 \\
Concordo & 50 & 8,91 & 72,73 & 58,82 & 39,53 \\
Concordo fortemente & 4,55 & 8,91 & 9,09 & 14,71 & 9,30 \\
\hline
\end{tabular}

Fonte: Maliniak e al. TRIP 2014 Faculty Survey

Ao se observar a Tabela VII acima, verifica-se que as comunidades da Argentina, Chile e Colômbia consideram as relações internacionais uma disciplina predominantemente estadunidense, com destaque para o Chile $(72,73 \%)$. Já no Brasil, destaca-se a soma dos percentuais, de aproximadamente $80 \%$, que discordam ou discordam fortemente dessa afirmação. Ademais, ressalta-se a posição do México que, embora sua comunidade esteja tão próxima aos Estados Unidos geograficamente, mostra que tal comunidade está dividida quanto à maior ou menor influência dos Estados Unidos nessa disciplina.

Em suma, não há um forte consenso entre as comunidades latino-americanas se a disciplina continua a ter o domínio dos Estados Unidos, da forma preconizada por Stanley Hoffman em 1977. As comunidades tendem a se dividir, onde, por um lado, Argentina, Chile e Colômbia reconhecem de maneira mais acentuada a predominância estadunidense, e, por outro lado, a comunidade brasileira e, 
em sequência, a mexicana parecem tender à discordância e resistência quanto à predominância inconteste dos Estados Unidos na área.

Porém, ao se analisar mais resultados do survey TRIP 2014, ainda relacionados à influência estadunidense na disciplina, torna-se possível constatar um maior consenso entre as comunidades latino-americanas. Isso é comprovado pelos resultados ao questionamento quanto à realização de um doutorado nos Estados Unidos e as possíveis maiores chances de sucesso acadêmico no futuro. Os Estados Unidos detêm os principais centros de excelência em docência e pesquisa do mundo e, para a maioria dos pesquisadores da América Latina, um estudante que tenha cursado seu doutorado ou parte dele nos Estados Unidos tem mais chances de ingressar na carreira acadêmica do que um estudante que tenha estudado apenas em seu país, como se pode observar na Tabela VIII a seguir:

Tabela VIII: Maiores chances de sucesso na carreira futura para quem cursa seu PhD nos Estados Unidos, por país

\begin{tabular}{|rrrrrrrrrr|}
\hline \multicolumn{2}{|c}{ Argentina } & \multicolumn{2}{c}{ Brasil } & \multicolumn{2}{c}{ Chile } & \multicolumn{2}{c|}{ Colômbia } & \multicolumn{2}{c|}{ México } \\
\hline Sim & 52,3 & Sim & 49,7 & Sim & 83,3 & Sim & 79,7 & Sim & 59,6 \\
Não & 31,8 & Não & 38,2 & Não & 5,6 & Não & 13,6 & Não & 31,9 \\
\hline
\end{tabular}

Fonte: Maliniak et al. TRIP 2014 Faculty Survey.

Assim, observa-se que, nos cinco países, a maioria acredita que quem realizou seu doutorado ou parte dele nos Estados Unidos terá mais chances de sucesso futuro, havendo, portanto, uma alta expectativa do valor acadêmico agregado à formação intelectual do estudante, ao passar uma temporada de estudos nos Estados Unidos cursando seu PhD. Entretanto, nota-se que há uma notável diferença em termos de equilíbrio percentual entre os acadêmicos da Argentina, Brasil e México, por um lado, e do Chile e da Colômbia, por outro.

Na Argentina, Brasil e México, embora haja uma maioria que acredita em um aumento do valor acadêmico a partir da realização de um PhD nos EUA, há também uma significativa parcela que não acredita nessa afirmação, ou seja, que entende que não necessariamente o jovem que se doutorou nos Estados Unidos irá ingressar no mercado de trabalho mais facilmente. Já para os últimos, Chile e Colômbia, a grande maioria entende ser um ganho, em termos de vantagem comparativa, obter o PhD nos EUA. 
Vale também observar se há convergência ou não quanto às escolhas feitas para os principais programas de doutorado no mundo, para aqueles que desejam seguir a carreira acadêmica. Os dados apontados na tabela IX a seguir evidenciam que parece haver uma maior convergência quanto aos principais programas de doutorado na área de RI estarem nos EUA, embora alguns programas de doutorado da Inglaterra também se destaquem na percepção dos acadêmicos latino-americanos.

Tabela IX: Principais Programas de Doutorado para uma carreira acadêmica

\begin{tabular}{|c|c|c|c|c|c|c|c|c|c|}
\hline \multicolumn{2}{|c|}{ Argentina } & \multicolumn{2}{|l|}{ Brasil } & \multicolumn{2}{|l|}{ Chile } & \multicolumn{2}{|c|}{ Colômbia } & \multicolumn{2}{|c|}{ México } \\
\hline $\begin{array}{c}\text { Harvard } \\
\text { University }\end{array}$ & 65,0 & $\begin{array}{c}\text { Harvard } \\
\text { University }\end{array}$ & 62,0 & $\begin{array}{c}\text { Harvard } \\
\text { University }\end{array}$ & 62,0 & $\begin{array}{c}\text { Harvard } \\
\text { University }\end{array}$ & 76,0 & $\begin{array}{c}\text { Harvard } \\
\text { University }\end{array}$ & 69,1 \\
\hline $\begin{array}{l}\text { Columbia } \\
\text { University }\end{array}$ & 50,0 & $\begin{array}{l}\text { University } \\
\text { of Oxford }\end{array}$ & 46,3 & $\begin{array}{l}\text { University } \\
\text { of Oxford }\end{array}$ & 46,3 & $\begin{array}{c}\text { London } \\
\text { School of } \\
\text { Economics } \\
\text { and Political } \\
\text { Science }\end{array}$ & 52,0 & $\begin{array}{l}\text { Columbia } \\
\text { University }\end{array}$ & 47,3 \\
\hline $\begin{array}{l}\text { Princenton } \\
\text { University }\end{array}$ & 45,0 & $\begin{array}{c}\text { London } \\
\text { School of } \\
\text { Economics } \\
\text { and Political } \\
\text { Science }\end{array}$ & 42,6 & $\begin{array}{c}\text { London } \\
\text { School of } \\
\text { Economics } \\
\text { and Political } \\
\text { Science }\end{array}$ & 42,6 & $\begin{array}{l}\text { University } \\
\text { of Oxford }\end{array}$ & 44,0 & $\begin{array}{c}\text { Yale } \\
\text { University }\end{array}$ & 40,0 \\
\hline London & & & & & & & & & \\
\hline $\begin{array}{l}\text { School of } \\
\text { Economics } \\
\text { and Political } \\
\text { Science }\end{array}$ & 35,0 & $\begin{array}{l}\text { University } \\
\text { of } \\
\text { Cambrigde }\end{array}$ & 35,2 & $\begin{array}{l}\text { University } \\
\text { of } \\
\text { Cambrigde }\end{array}$ & 35,2 & $\begin{array}{l}\text { Stanford } \\
\text { University }\end{array}$ & 40,0 & $\begin{array}{l}\text { University } \\
\text { of Oxford }\end{array}$ & 32,7 \\
\hline $\begin{array}{c}\text { Yale } \\
\text { University }\end{array}$ & 25,0 & $\begin{array}{l}\text { Princenton } \\
\text { University }\end{array}$ & 34,3 & $\begin{array}{l}\text { Princenton } \\
\text { University }\end{array}$ & 34,3 & $\begin{array}{c}\text { Yale } \\
\text { University }\end{array}$ & 32,0 & $\begin{array}{l}\text { Princenton } \\
\text { University }\end{array}$ & 30,9 \\
\hline
\end{tabular}

Fonte: Maliniak e al. TRIP 2014 Faculty Survey.

Os resultados do survey apontam que, para todas as cinco comunidades, a escolha por Harvard foi unânime, com média de $70 \%$. Na sequência, presentes em quatro países, estão London School, Princeton e Oxford. Tais escolhas refletem uma sintonia entre os acadêmicos da região quanto ao que consideram serem os melhores programas para formação acadêmica no âmbito do doutorado, bem como 
os dados apontam para uma predominância de programas norte-americanos e, em menor medida, os programas ingleses. Talvez seja nesse item, o da valoração de programas de excelência em PhD, que a influência estadunidense (e, em menor medida, inglesa) seja mais evidente e compartilhada entre os acadêmicos latino-americanos.

A predominância dos Estados Unidos também é revelada pelos dados quanto aos autores mais influentes das relações internacionais. E, da mesma forma, as comunidades de RI da região também tendem a ter visões parecidas nesse aspecto, como se pode observar na tabela X.

\section{Tabela X: Autores mais influentes da disciplina de relações internacionais, por país}

\begin{tabular}{|c|c|c|c|c|c|c|c|c|c|}
\hline \multicolumn{2}{|c|}{ Argentina } & \multicolumn{2}{|c|}{ Brasil } & \multicolumn{2}{|l|}{ Chile } & \multicolumn{2}{|c|}{ Colômbia } & \multicolumn{2}{|c|}{ México } \\
\hline $\begin{array}{l}\text { Alexander } \\
\text { Wendt }\end{array}$ & 45,7 & $\begin{array}{l}\text { Alexander } \\
\text { Wendt }\end{array}$ & 35,3 & $\begin{array}{l}\text { Alexander } \\
\text { Wendt }\end{array}$ & 46,7 & $\begin{array}{l}\text { Alexander } \\
\text { Wendt }\end{array}$ & 48,1 & $\begin{array}{l}\text { Robert O. } \\
\text { Keohane }\end{array}$ & 28,4 \\
\hline $\begin{array}{l}\text { Robert O. } \\
\text { Keohane }\end{array}$ & 25,7 & $\begin{array}{l}\text { Joseph S. } \\
\text { Nye Jr }\end{array}$ & 32,4 & $\begin{array}{l}\text { Joseph S. } \\
\text { Nye Jr }\end{array}$ & 40,0 & $\begin{array}{l}\text { Joseph S. } \\
\text { Nye Jr }\end{array}$ & 30,8 & $\begin{array}{l}\text { Alexander } \\
\text { Wendt }\end{array}$ & 18,9 \\
\hline $\begin{array}{l}\text { Barry } \\
\text { Buzan }\end{array}$ & 25,7 & $\begin{array}{l}\text { Robert O. } \\
\text { Keohane }\end{array}$ & 30,0 & $\begin{array}{l}\text { Robert O. } \\
\text { Keohane }\end{array}$ & 33,3 & $\begin{array}{l}\text { Kenneth } \\
\text { Waltz }\end{array}$ & 25,0 & $\begin{array}{l}\text { Joseph S. } \\
\text { Nye Jr }\end{array}$ & 17,6 \\
\hline $\begin{array}{l}\text { Robert W. } \\
\text { Cox }\end{array}$ & 20,0 & $\begin{array}{l}\text { Barry } \\
\text { Buzan }\end{array}$ & 27,1 & $\begin{array}{l}\text { Francis } \\
\text { Fukuyama }\end{array}$ & 20,0 & $\begin{array}{l}\text { Barry } \\
\text { Buzan }\end{array}$ & 23,1 & $\begin{array}{l}\text { Kenneth } \\
\text { Waltz }\end{array}$ & 13,5 \\
\hline $\begin{array}{l}\text { Joseph S. } \\
\text { Nye Jr. }\end{array}$ & 20,0 & $\begin{array}{l}\text { Kenneth } \\
\text { Waltz }\end{array}$ & 21,2 & $\begin{array}{l}\text { Samuel P. } \\
\text { Huntington }\end{array}$ & 20,0 & $\begin{array}{l}\text { Robert O. } \\
\text { Keohane }\end{array}$ & 23,1 & $\begin{array}{l}\text { Samuel P. } \\
\text { Huntington }\end{array}$ & 10,8 \\
\hline
\end{tabular}

Fonte: Maliniak e al. TRIP 2014 Faculty Survey.

Assim, nas cinco comunidades de RI latino-americanas, autores estadunidenses dominam as listas ou ranking de autores mais influentes na área. No entanto, a Argentina é o país mais diversificado ao incluir dois de origem canadense entre os cinco primeiros de sua lista (Barry Buzan e Robert Cox). Também é notório que todas as cinco comunidades identificam, como autores mais influentes, estadunidenses de perspectivas teóricas tradicionais positivistas (liberais e realistas), porém quase todos, com exceção do México, indicam também um autor construtivista como o autor mais influente na comunidade daquele país (Barry Buzan ou Alexander Wendt). 
Essa predominância estadunidense é também notável quando são listadas as revistas consideradas as mais influentes para a área de RI, o que reforça a percepção sobre o domínio estadunidense na produção científica da área.

\section{Publicações}

Em termos de publicações, é possível também observar uma variação entre os produtos mais valorizados nas instituições de origem dos pesquisadores, pois, em caráter de exemplo, livros de editoras universitárias ou comerciais, artigos em revistas nacionais de alta qualificação ou periódicos com alta pontuação são mais bem classificados do que artigos de revistas internacionais de alto impacto e avaliados por pares. Ademais, existe certo consenso entre os pesquisadores de todos os cinco países em valorar menos publicações tais como posts em blogs, blog de ciência política, ou artigo em jornal de circulação nacional, em magazine ou em relatórios de política.

A pesquisa incluiu também uma pergunta sobre qual o peso que a disciplina deveria atribuir a um artigo publicado em alguns tipos de publicações, quando se trata de definir a posição permanente de um professor na carreira docente, comparadas àquelas publicações, como um artigo em um periódico, que utilize a revisão por pareceristas. As respostas revelam que o livro de uma editora universitária nacional ou estrangeira, ou de uma editora comercial deveria ter mais valor do que o artigo de um periódico revisado por pareceristas.

Coerentemente com os resultados anteriores, os pesquisadores daqueles países não consideram a citação indexada como a melhor maneira de medir o impacto acadêmico de uma determinada publicação. Na Colômbia (45,7\%), México $(51,8 \%)$, Brasil $(33,3 \%)$ e Argentina (58,8\%), os pesquisadores não usam um sistema formal de classificação como o Social Science Citation Index-SSCI, Índice de Citação de Ciências Sociais. Para julgar a qualidade de um determinado periódico, por exemplo, no caso do Chile, a maior parte dos entrevistados (50\%) prefere um processo informal ao SSCI. Apesar disso, os pesquisadores latino-americanos reconhecem que alguns periódicos, sobretudo de origem nos EUA, publicam os artigos com maior influência sobre a forma como a disciplina é definida. 


\section{Tabela XI: Quatro periódicos que publicam artigos com grande influência na disciplina de RI}

\begin{tabular}{|c|c|c|c|c|c|}
\hline Ranking & Colombia & Chile & Mexico & Brazil & Argentina \\
\hline 1. & Foreign Affairs & Foreign Affairs & Foreign Affairs & Foreign Affairs & $\begin{array}{l}\text { International } \\
\text { Organization }\end{array}$ \\
\hline 2. & Foreign Policy & Foreign Policy & $\begin{array}{l}\text { International } \\
\text { Organization }\end{array}$ & $\begin{array}{l}\text { International } \\
\text { Organization }\end{array}$ & $\begin{array}{l}\text { International } \\
\text { Security }\end{array}$ \\
\hline 3. & $\begin{array}{l}\text { International } \\
\text { Organization }\end{array}$ & $\begin{array}{l}\text { International } \\
\text { Studies } \\
\text { Quarterly }\end{array}$ & Foreign Policy & $\begin{array}{l}\text { Revista } \\
\text { Brasileira } \\
\text { de Política } \\
\text { Internacional }\end{array}$ & World Plitics \\
\hline 4. & $\begin{array}{l}\text { American } \\
\text { Journal of } \\
\text { Political Science }\end{array}$ & World Politics & $\begin{array}{l}\text { Le Monde } \\
\text { Diplomatique }\end{array}$ & $\begin{array}{l}\text { International } \\
\text { Security }\end{array}$ & Millennium \\
\hline
\end{tabular}

Quanto aos periódicos de maior influência na área, percebe-se que há, de modo geral, uma consonância quanto às percepções dos acadêmicos latino-americanos. Em primeiro lugar, o periódico International Organization é o único periódico classificado pelos estudiosos latino-americanos dos cinco países dentro do ranking dos quatro mais importantes. Revistas mais focadas em política internacional do que em discussões teóricas, tais como Foreign Affairs, e, em menor proporção, Foreign Policy, são reconhecidas por quatro das cinco comunidades com um lugar privilegiado no ranking, o que poderia estar relacionado ao fato de que a maioria dos pesquisadores latino-americanos consideram que o meio acadêmico e a prática política caminham juntos e deveriam estar vinculados.

O Brasil é o único caso cuja comunidade de RI classifica uma revista nacional (Revista Brasileira de Política Internacional-RBPI) como um dos meios mais influentes na disciplina, algo que nos convida a pensar sobre o desenvolvimento do campo no país e sua inserção nos debates globais (ou, em termos contrários, também de um crescimento de uma atitude paroquial por parte dos pesquisadores brasileiros). A Argentina é o único país onde um periódico que não seja mainstream, como o Millennium, é escolhido como um dos quatro mais influentes da disciplina, o que sugere que abordagens alternativas e críticas são mais valorizadas por estudiosos desse país do que por seus pares no restante da América Latina. 
Há, por fim, também um consenso entre os pesquisadores das cinco comunidades quanto às editoras com a maior influência no campo das relações internacionais. Há duas editoras universitárias que são reconhecidas pelos estudiosos da Colômbia, Brasil, México e Argentina dentro do ranking das quatro mais influentes: Oxford University Press e Cambridge University Press. Editoras comerciais, como Routledge e Palgrave-MacMillan, foram também classificadas em quatro das cinco comunidades como as mais influentes. O México, por sua vez, expressou uma posição distinta, onde pesquisadores mencionaram editoras universitárias como as mais influentes: tais como Cambridge, Columbia, Cornell e Harvard.

\section{Política Internacional}

Um dos resultados importantes do survey de 2011, em países latino-americanos, foi a existência de uma relação entre interesses de pesquisa e percepções da política internacional, bem como entre o lugar que os países ocupam no mundo e suas respetivas políticas externas. O survey do TRIP 2014 revela que houve mudanças que trouxeram novas questões significativas a serem analisadas nessa última seção.

Pesquisadores da Colômbia $(48,4 \%)$, Chile $(40 \%)$ e Brasil $(27,4 \%)$ consideram que a região mais estratégica do mundo para seus respectivos países é a América Latina. Para os argentinos (42,8\%) é a América do Sul e, para os mexicanos $(60,7 \%)$, é a América do Norte. Existe também consenso entre os estudiosos dos cinco países sobre quais regiões são menos importantes em termos estratégicos: Ásia Central, Oceania, Rússia e países da antiga União Soviética, Turquia e África Subsaariana.

Quanto aos desafios ou pressões enfrentadas pelas políticas externas dos países latino-americanos nos próximos 10 anos, as opiniões não são unânimes, como se observa na Tabela XII abaixo. Acadêmicos colombianos e mexicanos concordam em identificar o crime organizado transnacional como um desafio mais importante do que as políticas externas que seus países enfrentam hoje. As comunidades do Chile, Brasil e Argentina identificam a integração regional como a principal preocupação política do momento. Ambas as tendências são explicadas precisamente por problemas históricos e atuais: Colômbia e México compartilham percepções de ameaça não só por causa do tráfico de drogas, mas também pela existência de outros tráficos ilegais, como armas ou pessoas. Da mesma forma, a integração regional é uma questão importante para países como Argentina ou Brasil, que desenvolveram esforços e projetos importantes durante as duas últimas décadas em matéria de integração regional. 


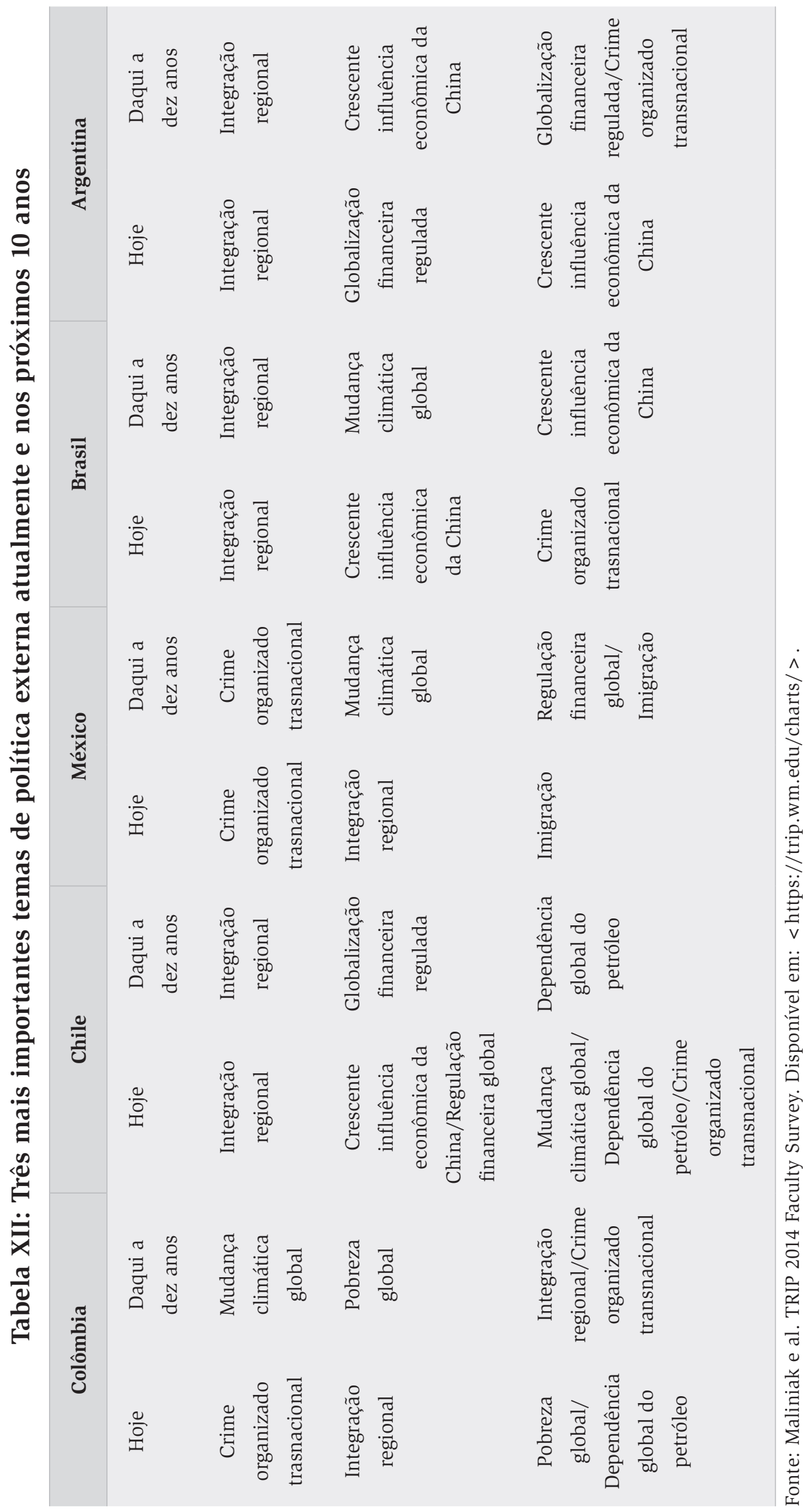


Os tópicos que poderiam ser consideradas questões globais, como a regulação financeira global, a pobreza global ou a crescente influência econômica da China são considerados também como relevantes para as comunidades dos cinco países, com algumas nuances. A influência da China é uma questão que sobressai para os estudiosos chilenos e brasileiros de hoje, e será um tema importante para os argentinos ao longo dos próximos dez anos. Ademais, o tema da regulação financeira global ocupa uma posição importante atualmente na percepção dos chilenos e argentinos e será importante nos próximos dez anos para os mesmos. O Chile e a Colômbia identificam como um problema central a dependência global do petróleo.

Pode-se observar que existe uma congruência entre os problemas identificados na atualidade e os problemas identificados ao longo dos próximos dez anos. Isso poderia significar que os estudiosos latino-americanos percebem os desafios à política externa como um processo razoavelmente estável e/ou que a comunidade reconheça esses problemas como estruturais e, em consequência, capazes de desafiar seus respectivos países mesmo no futuro próximo.

Quanto ao princípio da não intervenção, o survey trouxe alguns questionamentos quanto à postura dos acadêmicos no que diz respeito a intervenções internacionais em situações de conflito ou abusos contra os direitos humanos. É importante notar que as comunidades da Colômbia, Chile e Brasil tendem a apoiar algumas intervenções militares, em contraste com os acadêmicos do México e da Argentina, que parecem acolher mais fortemente o princípio da não intervenção, o qual tem raízes importantes na história da América Latina. Essa mudança sobre a intervenção militar torna-se também interessante porque mais de $54,2 \%$ acredita, por exemplo, que foi uma decisão acertada do ex-presidente dos EUA Barack Obama retirar as tropas norte-americanas do Iraque até o final de 2013 e segmentos importantes das comunidades latino-americanas não têm uma ideia clara de quão determinante foi a ausência de ação e de intervenção, direta e explícita, das tropas dos EUA na Síria para o crescimento do ISIS (Estado Islâmico) durante os últimos anos. Em outras palavras, os dados parecem apontar para a existência de um dilema entre as comunidades latino-americanas de RI: cambiante entre apoiar ou não apoiar as intervenções.

Ainda no que diz respeito a percepções de política internacional e governança global, nota-se que as percepções sobre instituições de governança global não têm sido muito otimistas na região. O survey incluiu duas perguntas sobre tal aspecto, uma sobre a regulação financeira e outra sobre doenças pandêmicas. Os resultados permitem afirmar que somente os pesquisadores chilenos têm 
confiança nas medidas e políticas que certas instituições podem adotar a fim de evitar uma crise financeira semelhante à crise financeira de 2008 ou à propagação de doenças pandêmicas. No caso dos acadêmicos colombianos, mexicanos, argentinos e brasileiros, há uma forte tendência a desconfiar de instituições financeiras internacionais, ao passo que os argentinos são mais otimistas em relação às instituições de saúde.

Nesse sentido, não é surpreendente que a maioria dos pesquisadores considere a ação do Estado como um dos principais meios de política externa para influenciar o comportamento de outro Estado, em detrimento de instituições de governança global. Ferramentas como a extensão ou retirada de assistência econômica, a imposição de sanções comerciais ou concessões comerciais, a promoção ou restrição de investimentos privados são considerados, por parte das comunidades dos cinco países, como poderosos instrumentos para mudar comportamentos de outros Estados, o que, no limite, pode ser evidência de uma percepção de mundo que tende a ser estadocêntrica.

\section{Conclusões}

Esse relatório teve por objetivo principal divulgar amplamente para o meio acadêmico as principais tendências verificadas nos resultados do projeto Teaching Research and International Policy (TRIP) de 2014 para os países da América Latina: Argentina, Brasil, Chile, Colômbia e México. Os resultados trouxeram percepções em torno da comunidade epistêmica latino-americana de Relações Internacionais, quanto ao seu formato, preferências metodológicas, epistemológicas, percepções quanto à dominação norte-americana da área e impressões sobre política internacional.

Um objetivo secundário, mas não menos importante deste relatório, foi possibilitar o levantamento de possíveis reflexões e questionamentos sobre a condução da disciplina de Relações Internacionais, não só no Brasil, mas na América Latina, sobre como é essa comunidade, como pensa e de que forma a área está se consolidando na região. Nesse sentido, possíveis reflexões sobre uma maior ou menor autonomia na área são imprescindíveis para a continuidade de seu processo de adensamento na região.

Tecer considerações finais em um report dessa natureza é uma tarefa das mais desafiadoras, pois qualquer generalização que se faça deve ser balanceada pelo 
fato de se tratar de um survey, cujo alcance foi de cerca de 55,4\% da comunidade identificada naquela ocasião. Entretanto, ao não se levantar considerações gerais acerca do que pôde ser identificado, perde-se a oportunidade de compreender melhor a comunidade latino-americana de Relações Internacionais que está em ascensão.

Portanto, sem perder tal ressalva de vista, a partir dos dados levantados, percebe-se que a comunidade latino-americana está em pleno crescimento, tratando-se de uma comunidade jovem e predominantemente masculina. Quanto às posições ideológicas, há certa inclinação a posições de centro-esquerda, sobretudo no que se refere a questões de âmbito social.

Primeiramente, no campo metodológico, observou-se significativa parcela da comunidade que se debruça no método qualitativo, e posições híbridas quanto à epistemologia e às escolhas paradigmáticas (teóricas). Tal fato é imprescindível para se refletir sobre esse caráter flexível e, em alguma medida, autônomo do pensamento sistemático latino-americano, ao se produzir cientificamente na área de Relações Internacionais, a qual, em maior ou menor medida, não parece se preocupar em se alinhar ao mainstream epistêmico. Entre as comunidades, chamaram atenção o Chile, por demonstrar ser mais alinhado às comunidades mainstream, bem como o México, que, embora tão próximo aos EUA, parece demonstrar posições autônomas e igualmente híbridas quanto ao campo científico de Relações Internacionais.

Em conseguinte, a dominação norte-americana na área pôde ser observada de forma mais evidente nos resultados quanto à percepção dessa dominação e, de forma tangente, quando se observam as reações quanto aos melhores programas de doutorado do mundo, sobre perspectivas de carreira de jovens que cursam seus PhDs ou parte deles nos EUA, ou mesmo quando questionados sobre os journals e autores mais influentes da área. A comunidade brasileira, nesse sentido, foi uma exceção importante, ao demonstrar desconfiança quanto a alguns desses questionamentos, bem como ao acrescentar uma revista brasileira entre as mais importantes da área.

Em terceiro lugar, no que se refere às impressões sobre política internacional, percebeu-se uma convergência entre as comunidades no que diz respeito às questões de política externa que afligem seus respectivos países, e aquelas que seguirão presentes no futuro próximo. Da mesma forma, foi possível perceber uma convergência ao expressarem certa desconfiança quanto à real capacidade de instituições de governança global, seja financeira ou de saúde, para solucionar 
problemas e, dessa forma, tendem a aceitar que os Estados ainda são players centrais da política internacional, e, por meio de suas ações clássicas, como auxílio econômico, bloqueios e sanções, continuam a obter seus resultados políticos esperados do meio internacional.

Por fim, é importante salientar a importância do projeto Teaching Research and International Policy (TRIP), não como o único, mas como um dos instrumentos mais vibrantes existentes hoje para captar a identidade da comunidade epistêmica de qualquer país entre os pesquisados. Dessa forma, encoraja-se a participação efetiva e ampla da comunidade no survey, seja com a finalidade de fomentar reflexões e debates sobre a comunidade epistêmica de relações internacionais, seja para incrementar publicações que se baseiem nos dados do survey no país.

\section{Referências}

HOFFMAN, Stanley. An American Social Science: International Relations. Daedalus. Vol. 106, n. 3, 1977, 41-60.

Maliniak, Daniel, Susan Peterson, Ryan Powers, and Michael J. Tierney. 2014. TRIP 2014 Faculty Survey. Williamsburg, VA: Institute for the Theory and Practice of International Relations. Disponível em: < https://trip.wm.edu/charts/ > . 


\section{Instruções editoriais para os autores}

Os autores devem seguir estritamente as diretrizes abaixo; sua não observância poderá implicar em não aceitação do artigo submetido, sendo os autores orientados a adequar o arquivo submetido aos padrões requeridos.

1. O artigo deve ser inédito e redigido em português ou em inglês. Além de inédito, o artigo não deve estar em apreciação concomitante em nenhum outro periódico ou veículo de publicação, no todo ou em parte, no idioma original ou traduzido.

2. O arquivo a ser enviado deve estar em formato.doc ou.docx; use somente a formatação padrão do texto. Os autores devem retirar sua identificação das propriedades do arquivo.

3. Não serão aceitos artigos com mais de 4 (quatro) autores/co-autores. No caso de mais de dois autores, a equipe editorial se reserva o direito de solicitar informações sobre o papel de cada um dos autores no processo de desenvolvimento do artigo.

4. O autor deve submeter três arquivos:

4.1 Um arquivo contendo título, resumos, palavras chave, corpo do texto e referências. No texto do artigo, o responsável pela submissão deve eliminar qualquer referência que possa permitir sua identificação.

4.1.1 No caso de um trabalho fruto de pesquisa financiada, o autor deve abrir uma nota de rodapé na primeira página do artigo para se referir ao financiamento e às agências de fomento que o possibilitaram.

4.2 Um arquivo, a ser submetido como suplementar, contendo a identificação dos autores, sua titulação máxima e a instituição a qual se encontra atualmente filiado, um resumo do Curriculum vitae de, no máximo, 5 linhas, contendo titulação, função que desempenha na instituição à qual é filiado e a URL do Currículo Lattes. Em casos de artigos com múltiplos autores, a informação de todos os autores deve ser apresentada. Neste mesmo arquivo, o autor poderá incluir agradecimentos, se desejar.

4.3 Uma Carta ao Editor, que deve ser enviada também como arquivo suplementar, na qual assume que o conteúdo do trabalho apresentado é inédito, não contém nada que possa ser considerado ilegal, difamatório, que cause conflito de interesses ou que possa interferir na imparcialidade do trabalho apresentado.

5. O arquivo com o corpo do texto não deve conter nenhuma forma de identificação dos autores; a formatação do texto deve estar em espaço simples; fonte de 12-pontos; uso do itálico em vez de sublinhado (exceto em endereços URL); as figuras e tabelas devem ser inseridas no texto, e não no final do documento na forma de anexos. 
6. O artigo deve conter o mínimo de 7.000 e o máximo de 8.000 palavras, incluídos título, resumo e palavras chave (em português e em inglês), corpo do texto e notas de rodapé; excluídas as referências.

6.1 Serão adotadas no máximo cinco palavras-chave em cada idioma. Elas devem se referir ao objeto de estudo do artigo e ao referencial teórico e/ou temática utilizada para análise.

7. O artigo deve incluir um resumo em português e em inglês, entre 150 a 200 palavras para cada uma das versões. Lembramos que o resumo em ambos os idiomas integra o número mínimo e o máximo de palavras, conforme indicado no item 6 .

8. As notas de rodapé devem se restringir a esclarecimentos adicionais ao texto. Todas as referências de fonte bibliográfica ou outras deverão ser feitas no corpo do texto, conforme o sistema de citação Chicago (AUTOR, data).

8.1 As citações devem estar no mesmo idioma que o artigo. Assim, será acrescentada no corpo do texto a versão traduzida, e em nota de rodapé, a versão original da citação.

9. A formatação de tabelas, quadros e figuras deverá seguir o formato ABNT.

10. As referências devem ser listadas ao final do texto e devem se restringir àquelas efetivamente citadas no artigo. Deve ser observado estritamente o sistema Chicago (AUTOR, data). Não serão aceitas referências bibliográficas em notas de rodapé.

As mesmas deverão seguir os modelos abaixo, de acordo com o formato estabelecido pela NBR 6023 (2002) da ABNT.

10.1 Para artigos ou documentos eletrônicos:

Elementos: AUTOR(es). Título. Título da publicação. Local de publicação, numeração correspondente ao volume, número, mês e ano de publicação, paginação inicial e final. Indicar o endereço (link) onde o documento está disponível e a data de acesso ao artigo.

MIYAMOTO, Shiguenoli. Política Externa Brasileira: 1964-1985. Carta Internacional, v. 8, n. 2, 2013, p. 3-19. Disponível em: http://www. cartainternacional.abri.org.br/index.php/Carta/article/view/120/64. Acesso em: 14 jul. 2016.

10.2 Para Livros

Elementos: AUTORES(es). Título. Edição (a partir da $2^{a}$ edição). Cidade: Editora, ano de publicação.

SARAIVA, José Flávio S. Foreign Policy and Political Regime. Brasília, DF: IBRI, 2003. 
10.3 Para capítulos de livros:

Elementos: AUTOR(es) do capítulo. Título do capítulo. In: AUTOR(es) da obra (Org., Ed., Coord.) Título da obra. Edição (a partir da $2^{\text {a }}$ edição). Cidade: Editora, ano de publicação. Capítulo consultado e paginação da parte.

SNIDAL, Duncan. The politics scope: endogenous actors, heterogeneity and institutions. In KEOHANE, Robert O; OSTROM, Elinor. Local commons and global interdependence: heterogeneity and cooperation in two domains. London: Sage Publication, 1995. Cap. 2, p. 47-70.

10.4 Trabalhos apresentados em Eventos

Elementos: AUTOR(es). Título do trabalho apresentado. In: nome do evento, numeração do evento (se houver), ano e local (cidade) de realização, título do documento (anais, atas, tópico temático), local, editora, data de publicação e página inicial e final da parte referenciada.

VENTURA, Deisy de Freitas Lima; PEREZ, Fernanda Aguilar. A política externa de saúde de Dilma Rousseff (2011-2014): elementos preliminares para um balanço. In: $5^{\circ}$ Encontro Nacional da ABRI, 2015, Belo Horizonte. Anais Eletrônicos. Disponível em: < http://www.encontronacional2015. abri.org.br/site/anaiscomplementares?AREA = 14\%2017 > . Acesso em: 14 jul. 2016.

11. No ato da submissão, todas as informações requeridas no sistema deverão ser devidamente preenchidas.

\section{Condições para submissão}

Como parte do processo de submissão, os autores são obrigados a verificar a conformidade da submissão em relação a todos os itens listados a seguir. As submissões que não estiverem de acordo com as normas serão devolvidas aos autores.

1. A contribuição é original, inédita e não está sendo avaliada para publicação por outra revista. Caso contrário, deve-se justificar em “Comentários ao editor”.

2. O arquivo da submissão está em formato Microsoft Word, OpenOffice ou RTF.

3. URLs para as referências foram informadas quando possível.

4. O texto está em espaço simples; usa uma fonte de 12-pontos; emprega itálico em vez de sublinhado (exceto em endereços URL); as figuras e tabelas estão inseridas no texto, não no final do documento na forma de anexos.

5. O texto segue os padrões de estilo e requisitos bibliográficos descritos em Diretrizes para Autores, na página Sobre a Revista.

6. Em caso de submissão a uma seção com avaliação pelos pares (ex.: artigos), as instruções disponíveis em Assegurando a avaliação pelos pares cega foram seguidas. 

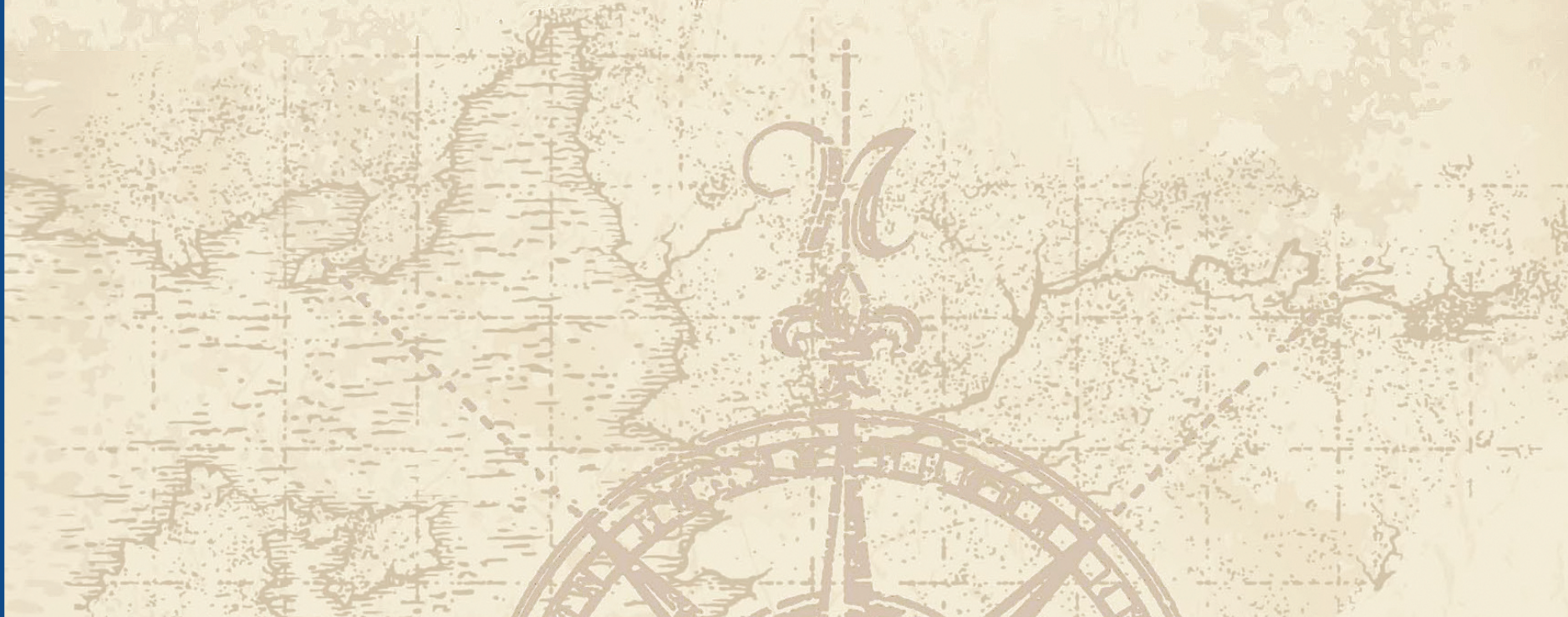

for

$=0-(x)$

$=3$
-0.4
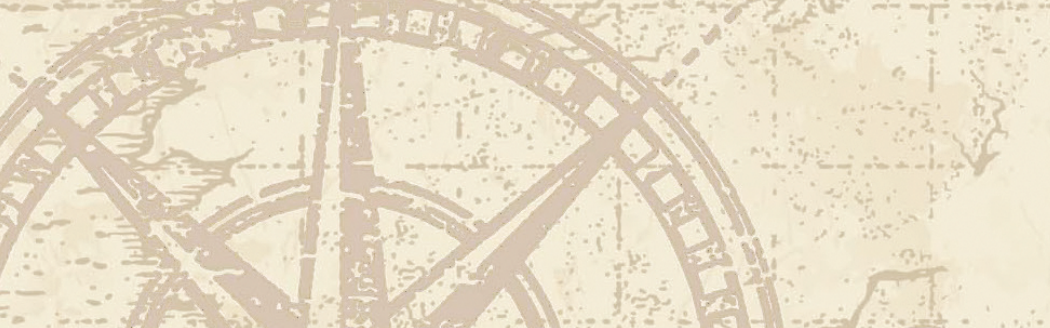